\title{
Serial Analysis of Gene Expression in human keratinocytes and epidermis
}

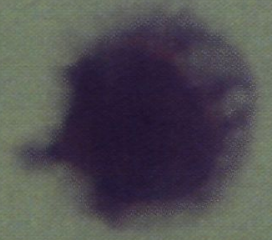

Bastiaan J.H. Jansen 

Serial Analysis

of Gene Expression in

human keratinocytes

and epidermis 



\section{Serial Analysis of Gene Expression in human keratinocytes and epidermis}

Een wetenschappelijke proeve op het gebied van de Medische Wetenschappen

\section{Proefschrift}

ter verkrijging van de graad van doctor aan de Katholieke Universıteir Nijmegen, volgens besluit van het College van Decanen in het openbaar te verdedigen op woensdag 22 mei 2002 des namiddags om 1.30 uur precies

door

Bastiaan Jan Herman Jansen

geboren op 4 april 1970 te Boxtel 
Prof. dr. dr. P.C.M. van de Kerkhof

Co-promotor:

Dr. J. Schalkwijk

Manuscriptcommissie: Prof. dr. A. Geurts van Kessel (vooritter)

Prof. dr. E.J.J. van Zoelen

Dr. G. Adema 
'All this will not be finished in the first hundred days. Nor will it be finished in the first thousand days, nor in the life of this administration, nor even perhaps in our lifetime on this planet. But let us begin.'

John F. Kennedy 
Jansen, B.J.H.

Serial Analysis of Gene Expression in human keratinocytes and epidermis

ISBN: 90-9015763-8

Printed by Ponsen \& Looijen B.V., Wageningen, the Netherlands

Design: Wilma van Wijnen, Amsterdam

Cover illustration

Cultured, undifferentiated keratinocyres undergoing apoptosis upon induction by TNF-related apoptosis inducing ligand (TRAIL), cells were stained with haematoxylın/eosin and visualized by means of light microscopy

No part of this book may be reproduced, stored in a database or retrieval system, or published in any form or way, electronically, mechanically, by print, photoprint, microfilm, or otherwise copied for public or private use, without the written permission of the author All published papers and figures are reprinted with permission and with credit to their resource 
11 Molecular bılogy of gene expression 12

12 Gene expression profilıng Is

13 Serial Analysis of Gene Expression: $\quad$ I9

1.31 Principles of SAGE $\quad$ I9

132 Overview of the SAGE technıque 20

133 Analysis and verification of SAGE data 22

1.34 How to isolate an unknown gene with $\quad 24$ an unknown SAGE tag

13.5 Adaptations of the SAGE protocol 25

136 Advantages and problems of SAGE 26

14 The human skun $\quad 27$

$\begin{array}{lll}14.1 & \text { Structure and function } & 27\end{array}$

142 The keratınocyte culture model 29

143 Gene expression in human keratınocytes 30

15 The tumor necrosis factor family and its role in the epıdermıs 34

Aim of this thesis $\quad 38$

CHAPTER 2 Serial Analysis of Gene Expression in differentiated cultures $\quad 5$ I of human epidermal keratinocytes (SAGE) libraries 


\section{Contents}

CHAPTER 4 A partial transcriptome of human epidermis

CHAPTER 5 TNF-related apoptosis inducing ligand (TRAIL) triggers apoptosis in human epidermal keratinocytes in the absence of internucleosomal DNA fragmentation

CHAPTER 6

Cystatin M/E Expression is restricted to differentiated epidermal keratinocytes and sweat glands: a new skin-specific proteinase inhibitor that is a target for cross-linking by transglutaminase

Nederlandse samenvatting

List of abbreviations

List of publications

Dankwoord

Curriculum vitae

Colour illustrations 


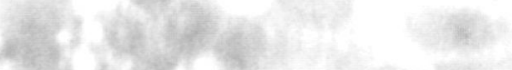
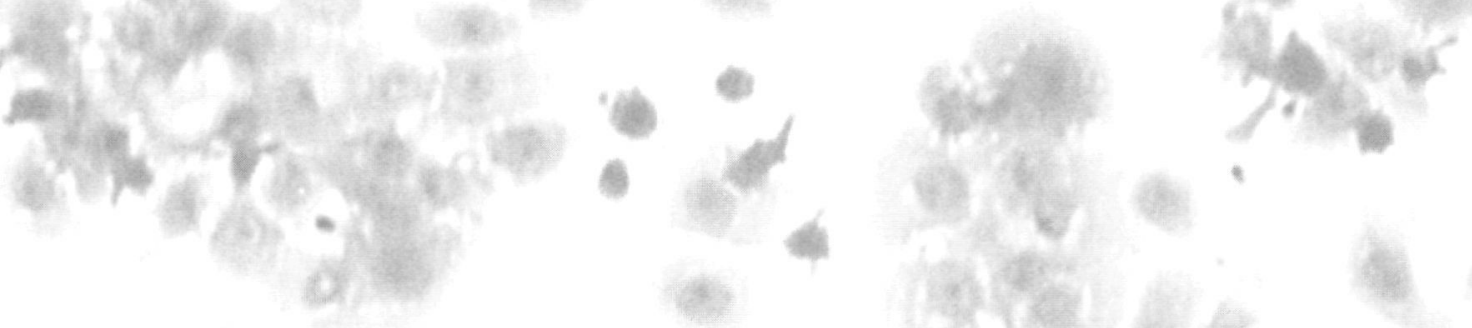

손단

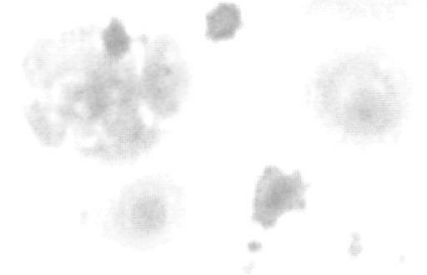

(8)

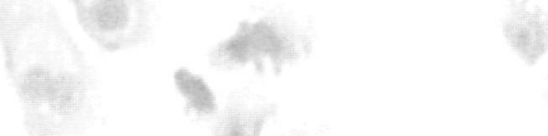

Aty
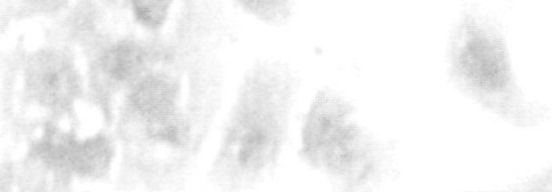

ats

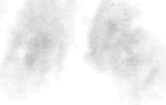

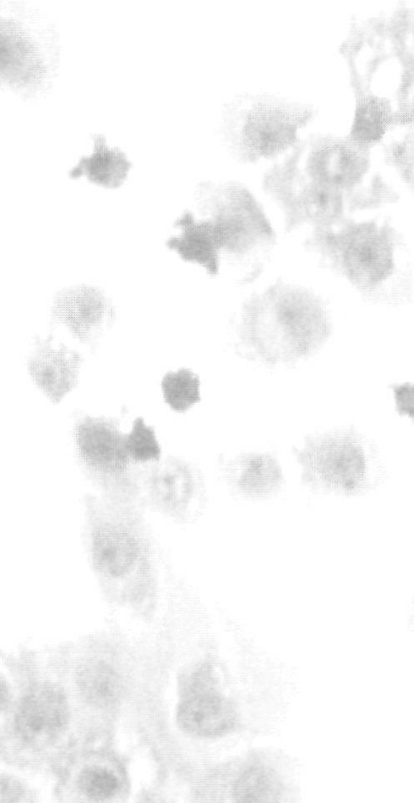

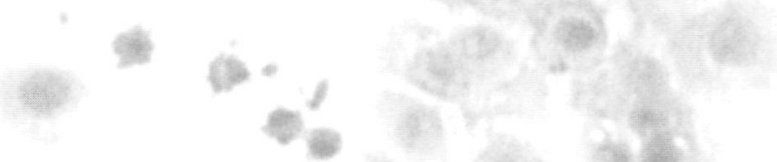

watin

e the 날

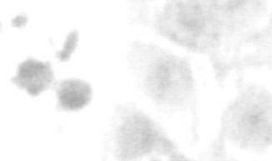

34:

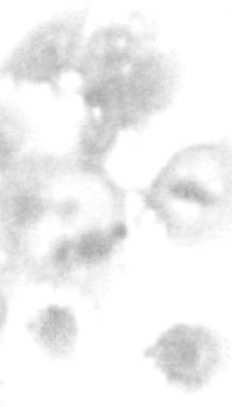

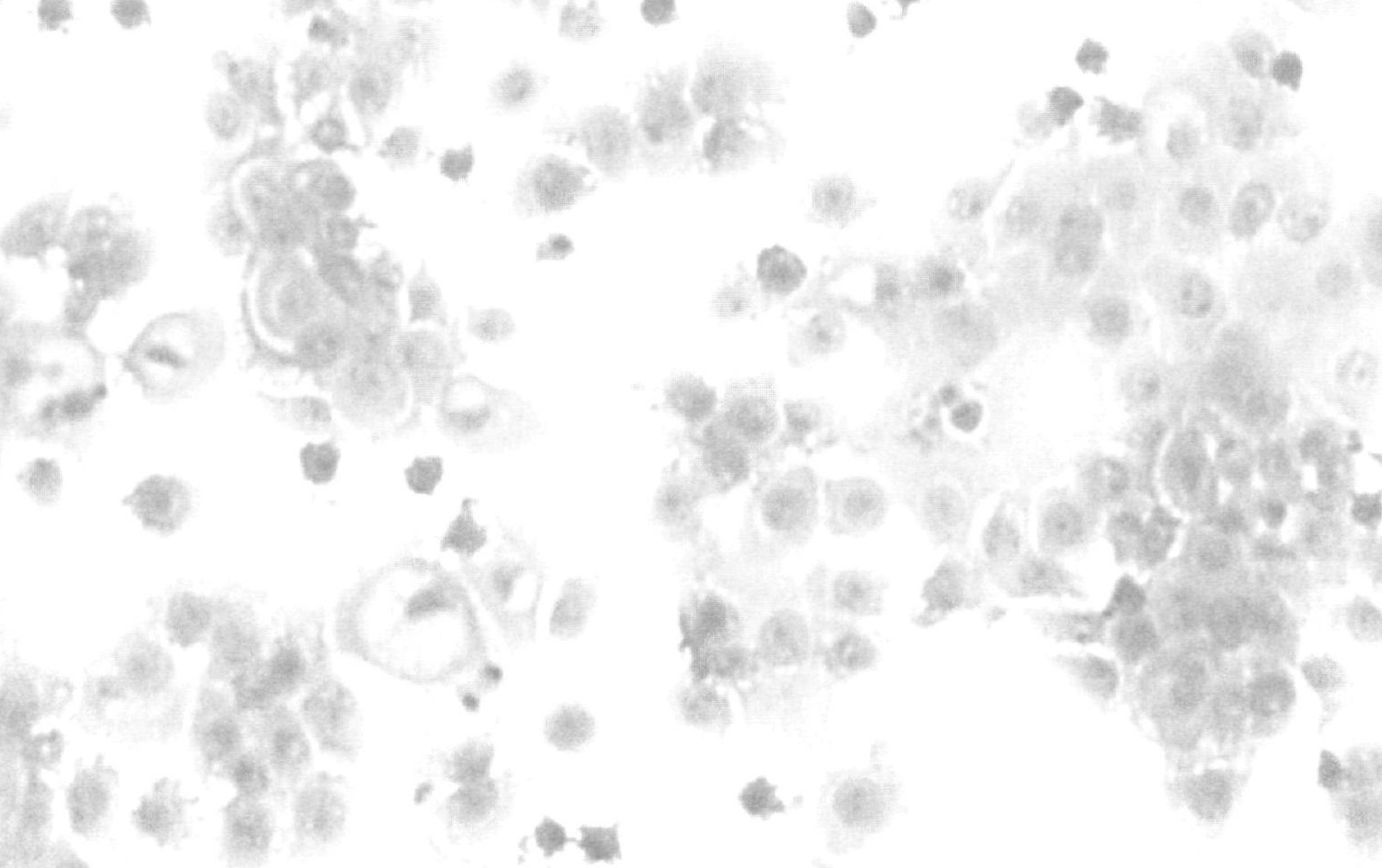

iㅕㄴ 8

(192)

rete

CHAPTER 1

Introduction

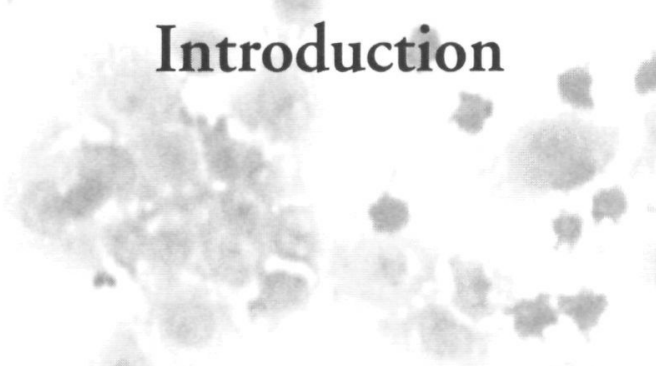

ant

(4)

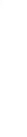

cas

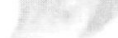



Over the course of the last three decades, the rapid development of molecular biology and molecular genetics has greatly increased our knowledge of the complex structure of genes and their regulation However, only over the last decade we are beginning to explore the intricate relations between multuple genes We are now able to identify complete sets of genes which play important roles in normal physiology and disease in a variety of organisms This giant leap forward would not have been possible without the development of borh 'wet' tools in order to identify large amounts of expressed genes at once, as well as tools that allow computational analysis of these sets of genes, also referred to as bioinformatics Gene expression profiling, as this type of analysis generally is being called, was preceded by technologies that did not require extensıve use of bioinformatics tools These earlier technologies allowed the analysis of only a restricted number of genes and data analysis could easily be done in a matter of days, mostly without the help of computers The interesung aspect of being able to generate large-scale expression profiles from two different samples is that a comparison between samples can be made This allows the identification of (clusters of) genes that are differentially regulated, and in fact can lead to the discovery of genes or genetic networks relevant to normal development and homeostasis of cells and tissues, disease, drug action and even clinical treatment regimens in a wide variety of pathological conditions Before exploring gene expression on a wide scale, it is important to know what genes are, how they are generally regulated, and what rechniques are avalable to explore global gene expression in a given cell type or tissue

This thesis centers around the use of Serial Analysis of Gene Expression (SAGE) for the study of differential gene expression in epidermal keratınocytes, both in vitro and in vivo SAGE comprises a set of techniques that allows quantitative and qualitative analysis of gene expression in a given cell type or tissue Here, it has been applied to cultured keratinocytes that have undergone normal and aberrant differentration, to normal epidermis and to a premalignant condition in the epıdermıs known as actınıc keratosıs Furthermore, unknown genes or genes that were unknown to be expressed in keratınocytes were investigated in more detail

In this introduction, an overview of gene structure and gene expression will be presented, followed by an in-depth review of the past and presence of gene expression profiling Furthermore, the structure and function of the human skın, epıdermal gene expression, as well as the keratinocyte culture model used in these studies will be discussed in more detail In the course of the project that has led to this thesis, two closely related cytokines, tumor necrosis factor- $\alpha$ (TNF- $\alpha$ ) and TNF-related apoptosis inducing ligand (TRAIL), took 
center stage and therefore an introduction on TNF family biology will be presented TNF family members play an important role in inflammatory skun conditıons like psoriasis, whereas they have also been implicated in skın development and homeostasis

\subsection{Molecular biology of gene expression}

Since SAGE measures expressed genes both qualitatıvely and quantitatively, it is important to consider what eukaryotic genes basically are, and what their structure is This is especrally important because knowing how genes are transcribed also explains oft-overlooked pitfalls that will arise during SAGE Genes are usually encoded by double-stranded deoxyribonucleic acid (dsDNA) molecules in the cellular nucleus (the genome), and much smaller genomes in organelles, like mitochondria in eukaryotes and chloroplasts in plants They can be considered units of transcription, 1 e units that can be transcribed by ribonucleic acid (RNA) polymerase from double-stranded DNA into single stranded RNA molecules This process does not only involve RNA polymerases, but also enzymes that enable unwinding and separation of dsDNA to generate single standed DNA (ssDNA), thus making it accessible to polymerases ${ }^{13}$ Furthermore, the process requires energy, which is generated by the hydrolysis of adenosine triphosphate (ATP) during transcription ${ }^{4} 5$ Additional transcription factors are often required to initiate RNA synthesis in response to specific stimuli from either inside our outside the cell As is outlined in Figure 1, a gene has to meet three basic requirements first, it should contain a site from which transcription starts (a promoter), second, it should contain information for its function or for the protein it encodes, and third, it should contain elements that enable termination of transcription ${ }^{6}$ ?

There are essentually three classes of genes the class that 1) encodes ribosomal RNAs (rRNAs), which form a structural part of the protein synthesis factory of the cell, the ribosome, and which account for approximately $85 \%$ of all RNA in a cell, the class that 11 ) encodes transfer RNAs (tRNAs) which account for approximately $10 \%$ of cellular RNA and which serve as adaptors for protein synthesis, and the class that 111) encodes messenger RNAs (mRNAs), which contain sequence information for the proteins they encode and serve as a template for protein synthesis, and which make up approximately $1-5 \%$ of all RNA in a cell ${ }^{89}$ "The latter class is essential for this thesis, as it is this class that is being analyzed in more detal by means of SAGE Gene expression is the process whereby a gene is actively being transcribed into a RNA molecule, which in turn can exert its function (in the case of rRNA and tRNA) or can be translated into a protein (in the case of mRNA) A fourth class of RNA that will not be discussed is the class of small nucleolar RNAs (snRNAs), which are stably complexed with nucleolar proteins in eukaryotic nuclei They play important roles in ribosome biogenesis and pre-mRNA processing $10 "$

Eukaryotic genes that encode mRNAs do not only contain the three basic, required, signals In fact, they have a much more complex genomic structure, since the eventual mRNA is encoded by several units, or exons, that are separated by introns The first exon is preceded by a promoter, which binds transcription factors and from which transcription takes place $^{312}$, and the last exon is followed by a transcription termination signal or polyadenylation site, most notably the sequence AATAAA Introns in the gene may also contain regulatory sequences for transcription Introns are excised during mRNA synthesis, and the remaining exons are spliced together by a multiprotein complex called spliceosome ${ }^{13}$ Transcription is terminated about 10 to 50 nucleotides downstream of the polyadenylation 


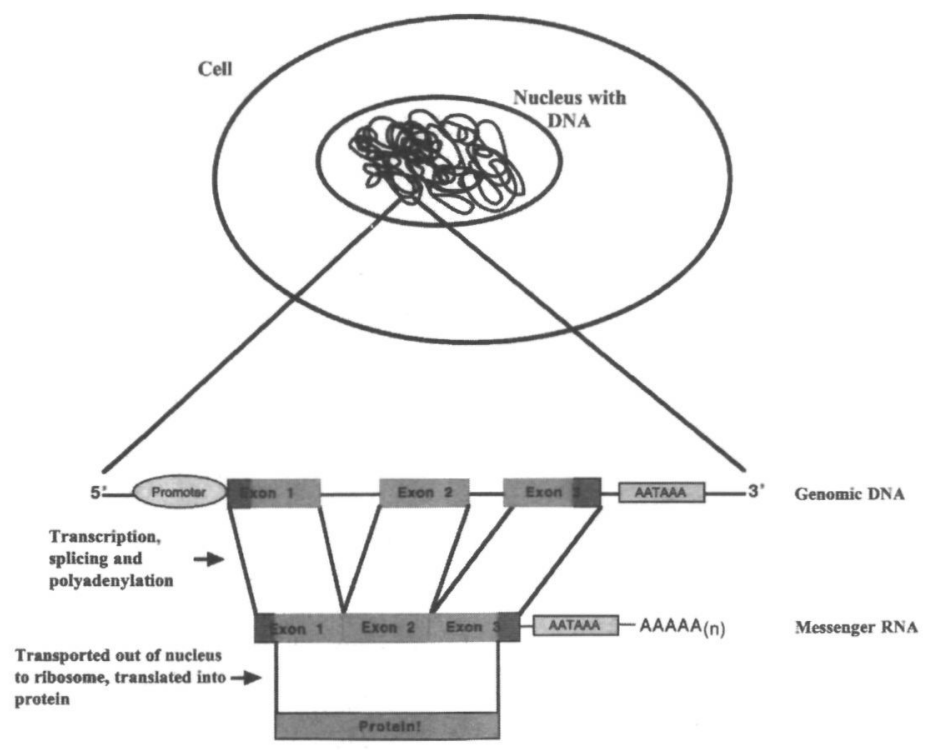

FIGURE 1 A simplified overview of eukaryotic gene expression.

site, and a stretch of up to 200 adenosine triphosphate residues is added to the 3' end of the transcript by a polynucleotidyl transferase (FIGURE 1), effectively adding a so-called poly-A tail to the mRNA. How transcription is terminated is not entirely clear, although data suggest that common repeats in the 3' untranslated (i.e. non-coding) region (3'-UTR) of mRNAs are at least involved in mRNA polyadenylation and stability ${ }^{14-16}$. Furthermore, it is important to realize that eukaryotic mRNAs are monocistronic, meaning that they only encode one polypeptide, whereas bacterial and viral RNAs can encode multiple different polypeptides ${ }^{17,18}$.

The fact that eukaryotic genes are characterized by an intron-exon structure also allows a certain level of plasticity with regard to the ultimate sequence and structure of an mRNA. First, exons can be skipped during transcription just like non-coding introns, potentially leading to a gene product with a different function. Examples include the Bcl-X gene, which encodes both a long $\left(\mathrm{Bcl}-\mathrm{X}_{\mathrm{L}}\right)$ protein involved in cell survival, and a short $\left(\mathrm{Bcl}-\mathrm{X}_{\mathrm{S}}\right)$ protein which promotes cell death ${ }^{19}$, and the FLIP gene also encodes short and long variants that promote or inhibit cell death, respectively ${ }^{20}$. Second, alternative polyadenylation may also influence the length of the mRNA, and thus its stability. Furthermore, both exon skipping and differential polyadenylation have implications for SAGE, as SAGE relies mostly on sequences in the 3'-UTR. Eukaryotic mRNA also contains a 5'-UTR, upstream of its coding sequence, and at its 5' end a modification called 'cap' ${ }^{21,22}$. The cap is formed by the addition of a guanine nucleotide to the 5' end of a mRNA in a peculiar way: the guanine triphosphate (GTP) reacts with the triphosphate at the 5' end of a mRNA chain in an unusual 5'-5' condensation, instead of the usual 3' -5 ' phosphodiester formation seen in mRNA chain elongation. The process is catalyzed by a 'capping enzyme' ${ }^{23}$. 
Transcription of genes can be either constitutive ('always on') or temporal ('on/off when required'). In the latter case, gene expression is initiated by intra- and/or extracellular signals that are relayed to a promoter of a gene. Promoters do exactly what their name implies: accommodate gene expression from the transcription start site when transcription factors bind to them. In addition, promoters may also contain sites that bind factors which repress transcription. Repressors can turn into enhancers when activated through specific biochemical signaling cascades, thus essentially functioning as a switch. These biochemical cascades in most cases involve the serial phosphorylation by kinases of target proteins, which in turn activate other proteins. Ultimately, transcription factors become activated and initiate transcription from the promoter of the target genes ${ }^{24.25}$. Many growth factors and cytokines are able to initiate a transcriptional program in this way, which leads to profound phenotypic changes that range from induction of proliferation and terminal differentiation to changes in cell behaviour. Examples include signaling pathways relevant for keratinocyte proliferation and differentiation, and will be discussed in more detail in CHAPTER 1.4.3, and proinflammatory and apoptotic signaling cascades induced by TNF family members, which will be discussed in CHAPTER 1.5 .

The amount of transcripts not only depends on the rate of transcription from its promoter, but also on the stability of the mRNA. For example, it is known that AU-rich elements (AREs) in the 3'-UTR are important in the regulation of mRNA stability of many cytokines. These AREs are targeted by various proteins, one of which is tristetraprolin (TTP), a protein that can suppress mRNA production by expediting mRNA decay through binding to a $3^{\prime}$ ARE ${ }^{26}$. TTP is antagonized by a protein called $H u R$, the human homologue of the ELAV (embryonal lethal abnormal vision) gene in Drosophila, a member of the so-called Hu-family of RNA binding proteins ${ }^{27}$. HuR is a target of the phosphatidylinositol 3 kinase and p38/MAPK pathways, and upon activation stabilizes cytokine mRNAs. One study suggests an integrated model of mRNA turnover control, where stabilizing (HuR) and destabilizing (TTP) AU-binding proteins compete and where the former are under the positive control of independent phosphokinase signaling pathways ${ }^{2 H}$. The turnover of $53 \mathrm{mRNA}$, a pro-apoptoric gene, is high in immortalized murine embryo fibroblasts, possibly explaining why p53 is not active in these cells. In addition, it has been suggested that certain repeats in the 3'-UTR of the p53 mRNA, which are found throughout mammalian genomes, are also involved in transcript stability, by an as yet undefined mechanism ${ }^{29}$. 10 .

When mRNAs have been synthesized, they are exported from the nucleus to the cytoplasmic ribosomes associated with the endoplasmic reticulum (ER), where they are translated into proteins. This nuclear export requires specialized proreins, which associate to sites of transcription ". Only coding sequences, beginning at an AUG trinucleotide, are translated into protein, ending at any of the stop codons UAA, UAG and UGA. Translation of mRNAs leads to the formation of polypeptides that usually are further processed to form mature proteins which then exert their function, ultimately leading to certain phenotypic chararteristics like proliferation, differentiation or apoptosis. It is clear that the level of mRNA of a particular gene does not necessarily reflect the rate of RNA synthesis and is also dependent on the rate of RNA decay, which can be differentially regulated, as pointed out before. Furthermore, there is proof that mRNA levels do not necessarily reflect protein expression levels "2. Translation of $\mathrm{mRNAs}$ can also be modulated by extracellular signals, increasing or reducing protein levels without primarily affecting transcription or mRNA decay ". In conclusion, gene expression is a complex process, and can be modulated at various stages from transcription to translation. Thus, it is especially important to keep in 
mind that gene expression profiles at the mRNA level are only an indication of which genes may be active, but by no means should be interpreted as a measure of gene or proteln activity.

\section{Gene expression profiling 1.2}

In the early days of molecular biology, there was virtually no way to directly identify genes. In fact, only indirect evidence suggested the exıstence of inheritable elements, which were associated with a phenorypic change: $\mathrm{X}$-rays could induce mutations in fruit flies and barley ${ }^{14}{ }^{35}$. Later, the chemical basis of nucleic acids, the building blocks of DNA and RNA, and of DNA itself was unraveled ${ }^{16}{ }^{18}$, and it was recognized that not DNA but RNA served as a template for protein synthesis " $" 10$. In 1956 Francis Crick ${ }^{41}$ proposed a pathway that is generally being referred to as The Central Dogma: chromosomal DNA functions as the template for RNA synthesis, while RNA subsequently moves to the cytoplasm where it serves as a template for protein synthesis in ribosomes. Although mRNA was discovered in $1961^{4244}$, it would roughly take another 15 years before the first method to detect mRNA was developed ${ }^{45}$. This method, Northern blotting, involves the transfer of electrophoretically separated RNA bands from an agarose gel to paper strips. It is in fact based on the same principle as Southern blotring, where DNA instead of RNA is used ${ }^{46}$. Originally, the RNA was coupled covalently to diazobenzyloxymethyl groups on the paper. Nowadays a whole array of different papers (or filters, as they are now generally being referred to), are commercially available. After transfer and appropriate treatment, specific RNA bands can be detected by hybridization with ${ }^{32} \mathrm{P}$-labeled DNA or RNA probes ${ }^{47}$ followed by autoradiography. This procedure allows detection of specific RNA bands with high sensitivity and low background. It also allows the comparison of two different samples and, if the right internal standard is used, densitometric analysis, either with a phosphoimager to detect radioactive signals, or by digital densitometric analysis of the autoradiographs. It is thus suitable for the analysis of mRNA expression of a very limited number of genes. Northern blotting is still used to detect RNAs to verify expression of genes, but has little value as a tool to investigate large-scale differential gene expression, since betrer methods are nowadays available.

Another method that has been used successfully for gene expression profiling is the RNase protection assay, the basis of which is a solution hybridization of a single-stranded, discrece-sized antisense probe(s) to an RNA sample. Small volume solution hybridization is far more efficient than traditional membrane-based hybridization, and can accommodare up to $100 \mu \mathrm{g}$ of total RNA or mRNA. After hybridization, any remaining, unhybridized probe and sample RNA are removed by digestion with a nuclease, usually S1 nuclease or RNase A, which specifically degrade single-stranded DNA and/or RNA. Then the nucleases are inactivated and the remaining double-stranded hybrids are precipitated. These products are separated on a denaturing polyacrylamide gel and are visualized by autoradiography. To quantitate $m R N A$ levels using $R$ Nase protection assays, the intensities of probe fragments protected by the sample RNA are compared with the intensities generated from either an endogenous internal control (relative quantitation) or known amounts of sense strand RNA ${ }^{48}$. Although this technique is more sensitive than Northern blotting, throughput is still low.

A widely used technique is subtractive hybridization, numerous variations of which have been reported. In general, they involve the hybridization of one population of $\mathrm{cDNAs}$ (tester) to an excess of mRNA or cDNA from another population (driver), followed by a 
separation of the unhybridized fraction (target; upregulated cDNAs) from the hybridized common cDNAs ${ }^{49}$. Subtractive hybridization was successfully used in 1984 to isolate the cDNA of the $\beta$ chain of the mouse T-cell receptor and other genes ${ }^{50}$ ". Earlier protocols required a lot of input material, of up to $20 \mu \mathrm{g}$ of $\mathrm{mRNA}$, which is highly inconvenient and laborious, and sometimes impossible to obtain from small samples. Therefore various variants have emerged that take advantage of PCR to enable the use of a lower amount of input material, to bolster cDNA yields of differentially expressed genes ${ }^{52}$, or to take advantage of suppressive PCR in suppression subtractive hybridization ( $\mathrm{SSH}$ ) to lower the number of false positives and to enrich rare cDNAs a 1000 - to 5000 -fold ${ }^{53}$. These modern versions are collectively referred to as representational difference analysis (RDA). Until recently, SSH was the most widely used protocol for gene expression profiling, because a commercial kit is available. In this protocol, two pools of tester cDNA are ligated to two different adapters, which serve as templates for PCR primers. In the first round of subtraction these pools are separately hybridized with excess driver cDNA, while in the second round these pools are combined and again hybridized with excess driver cDNA. After subtraction, only those differentially expressed cDNAs are amplified by means of suppressive PCR ${ }^{54}$ that contain two different adapters at each end; those that contain identical adapters will not amplify because they will self-anneal, and cannot be amplified exponentially, thus allowing selective enrichment of differentially expressed genes. On the upside, this technology potentially allows the identification of many differentially regulated genes at once, even those that are expressed at very low levels. The downside is that it is not suitable for quantitative measurements of gene expression.

One of the most popular and widely used techniques to investigate differential gene expression is probably differential display-polymerase chain reaction (DD-PCR, also referred to as mRNA differential display), since it is based on easy-to-apply, affordable molecular techniques, and relies on PCR "s . Variations of the methodology exist, the most notable being RNA arbitrarily primed PCR (RAP-PCR), which was developed independently from DD-PCR ${ }^{56}$, and is based on the use of arbitrary primers in both reverse transcription and PCR. Differential display is based on a series of steps: the isolation of undegraded cellular RNA; reverse transcription of the RNA with an 'anchored' oligo$\mathrm{dT}_{12-18} \mathrm{dN}_{\mathrm{I}-2}$ to produce a subset of single-stranded cDNAs; the PCR amplification with the same and/or another oligonucleoride to enrich a subset of cDNAs; and ultimately display on a polyacrylamide gel, where differences between two distinct pools of RNA can be visualized, and from which specific, differentially displayed bands can be excised and sequenced. The methodology has proven to be a very powerful tool to isolate new genes and investigare differential gene expression, but it is typically hampered by the fact that it also generates a lot of false positives ${ }^{53}$. In contrast to subtractive hybridization, however, it is far less laborious and much more cost-effective, and therefore it is still the preferred method of differential gene expression investigation for many cost-conscious laboratories ${ }^{57}$.

Quantitative PCR is becoming more and more the preferred choice to prove differences in expression of known genes but, in contrast to DD-PCR, does not allow the identification of unknown genes ${ }^{58,5)}$. It is, however, a more sensitive approach than Northern blotting and the RNase protection assay, and one can establish differences in expression levels of genes of which only a few mRNAs are present per cell. It is therefore expected that this technique will replace Northern blotting and the RNase protection assay in the future. It is now widely used in diagnostic laboratories to measure viral loads and cyrokines at the mRNA level. Quantitative PCR involves the amplification of an internal standard, preferably a gene of which it is known that it is not differentially expressed, and the amplifica- 


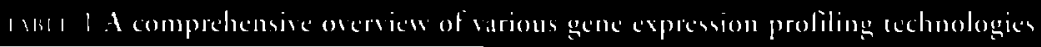

\begin{tabular}{|c|c|c|c|c|c|}
\hline $\begin{array}{l}\text { Expression } \\
\text { analysis } \\
\text { technology }\end{array}$ & $\begin{array}{l}\text { Amount of } \\
\text { template } \\
\text { required }(\mu \mathrm{g})\end{array}$ & Sensitivity & $\begin{array}{l}\text { Transcripts } \\
\text { covered (\%) }\end{array}$ & $\begin{array}{l}\text { Ability to } \\
\text { discover } \\
\text { new genes }\end{array}$ & Throughput \\
\hline Northem blorting & 0.1 (mRNA) & N/A & $<1$ & No & Low \\
\hline RNase protection & $1-100$ (total RNA) & N/A & $<1$ & No & Low \\
\hline Subtractive hybridization & 20 (mRNA) & N/A & $\mathrm{N} / \mathrm{A}$ & Yes & Low \\
\hline $\begin{array}{l}\text { RDA/Suppression } \\
\text { subtractive hybridization }\end{array}$ & 0.02 (mRNA) & $<1: 300,000$ & N/A & Yes & Medium \\
\hline DD-PCR & 0.5 (mRNA) & $\mathrm{N} / \mathrm{A}$ & 96 & Yes & Medium \\
\hline RAP-PCR & 0.012 (total RNA) & $\mathrm{N} / \mathrm{A}$ & $\mathrm{N} / \mathrm{A}$ & Yes & Medium \\
\hline Quantitative PCR & 0.01 & N/A & $\mathrm{N} / \mathrm{A}$ & No & Low \\
\hline SAGE $=$ & $\begin{array}{l}1 \text { (total RNA; } \\
\text { MicroSAGE) } \\
5 \text { (mRNA; } \\
\text { conventional SAGE) }\end{array}$ & $\begin{array}{l}\text { Varies from } \\
<1: 10,000 \\
\text { to }<1: 300,000\end{array}$ & $\begin{array}{l}\text { Varies from } \\
0 \text { to }>90\end{array}$ & Yes & Low \\
\hline cDNA Micro-array analys & $>10$ (cotal RNA) & N/A & N/A & No & High \\
\hline
\end{tabular}

* Numbers are based on quoted references mentioned in text; N/A, not applicable.

** Amount of input material and sensitivity and transcript coverage greatly depend on merhod and size of SAGE libraries, respectively.

tion of the gene of interest. The relative amounts of PCR product (relative to the internal control, that is) can be compared. Nowadays fluorescence-based kinetic (real-time) PCR allows the monitoring of amplification during a PCR, and more accurately reflects relarive expression levels of target genes ${ }^{60}$.

In general, drawbacks of the conventional methods described above are that throughput is low, and that gene expression analysis is semi-quantitative at best. One also runs into the risk that with PCR-based methods, selective amplification, or PCR bias, occurs, therefore possibly under- or overestimating the expression levels of genes. As with any protocol that depends on hybridization, there is also a risk of cross-hybridization between closely related genes, which may in turn lead to under- or overestimation of gene expression levels as well. A comprehensive overview of advantages and drawbacks of gene expression profiling technologies is given in TABLE 1 . 
Sequencing of cDNA clones provided a first glimpse of gene expression patterns in different human tıssues, but ultumately this approach proved to be more useful for the identification of genes than for the quantitative analysis of gene expression ${ }^{61}$ " 2 Only in the last decade technologies have been developed to examıne gene expression on a genome-wide scale (also referred to as genomics), and recently these technologies received a boost from the fact that the sequencing of the human genome has been finalized ${ }^{63}$ of It is estimated that human genome encodes about 30,000 genes, most if not all of which have been cloned, either as a complete cDNA, or as an expressed sequence tag (EST) These cDNAs and ESTs as well as oligonucleotides can be gridded onto filter arrays or microslides, which in turn can be hybridized with cDNAs derived from different pools of RNA, thus allowing the comparison and quantitative analysis of gene expression ${ }^{15-67}$ Before hybridization, RNAs from the pools to be compared are converted to cDNA in the presence of fluorescent nucleotides An internal control, usually a cDNA or oligonucleotide that is gridded onto the chip, and of which mRNA in a known concentration has been added to the RNA pools to be examined, is included Hybridization is performed in a small volume in order to improve sensitivity Relative fluoresence intensity is then measured and compared berween the samples ${ }^{6}$ When using two different chromophores, one can hybridize one single array The color of fluorescent spots then indicates whether a gene is up- or downregulated When using oligonucleotides, the density of unique sequences per array can be increased dramatically, and technology has been developed that allows the nucleotıde-fornucleotide synthesis of oligos on a micro-array ${ }^{69}$ More importantly, with the development of array-based screening technologies, it is now possible to examine the expression levels of thousands of genes at a time since arrays, be it filters or microslides, can accommodate literally tens of thousands of cDNAs or oligonucleondes Although high throughput array technology is ideal for the analysis of differential gene expression, only relative differences in expression level can be determined, and not absolute expression levels Still, a concern of the use of this technology is that cross-hybridization, a problem also seen in subtractive hybridization, may occur when dealing with highly homologous genes Furthermore, this technology requires substantial investments in robotics, for amplification and gridding of cDNAs, and detection equipment, makıng it a very costly affair

To date, only one technology has emerged that does not only allow the analysis of differential gene expression, but also the generation of absolute gene expression profiles Serial Analysis of Gene Expression (SAGE) will be described in more detal in the next para graph, as this thesis centers around the use of SAGE to examine differential gene expression in keratınocytes It is needless to say that many other expression profiling techniques have been developed, combinıng the advantages of existıng technology, or incorporating new technology in old protocols As these technologies are all based on existing protocols, they will not be discussed here

Another way to investigate gene expression is to determine the expression profiles at the protein level This is in part due to the fact thar mRNA expression levels not always reflect expression levels of the protein it encodes ${ }^{32}$, making it necessary to verify expression at the protein level Only recently high-throughput protocols have become avalable, and proteomics, as this branch of research is being referred to, is just beginning to develop Largescale 2-dimensional polyacrylamide gel electrophoresis (2D-PAGE), matrix-assisted laser desorption/ ionization time-of-flight mass spectrometry (MALDITOF-MS) and various chromatography technologies now allow the simultaneous analysis of many proteins, and is it expected that these will only improve ${ }^{7073}$ However, other problems arsse, as proteins may suffer from instability during analysis, and the same protein may undergo multuple 
modifications in cells due to natural processes, possibly hampering the analysis. However, both proteomics and genomics can go hand in hand, as they are complementary: expression levels ultimately have to be verified on either level.

It is clear that, with the advent of high-throughput gene expression analysis at both the mRNA and protein levels, a wealth of information can be generated with regard to the molecular nature of disease, development and homeostasis of organisms. The downside of these rechnologies is that they may be prohibitively expensive to execure. However, now that the human genome has been sequenced, these technologies are absolutely needed to unravel the mechanisms that underlie various biological processes, and they will certainly help biomedical research in its quest to understand human disease.

\section{Serial Analysis of Gene Expression}

Serial Analysis of Gene Expression (SAGE) was first described by Velculescu et al. in $1995^{74}$. SAGE allows the quantitative and qualitarive analysis of thousands of transcripts at a time and has already been used to construct a transcriptome of yeast ${ }^{75}$ and a partial transcriptome of $\operatorname{man}^{76}$, databases containing the complete expression profiles of (tissues of) an organism. It has also proven to be a useful tool in genomics, as a human transcriptome map has been constructed in an effort to identify clusters of genes on chromosomes of unusually high or low transcriptional acrivity in cancer ${ }^{7}$. Regions of highly expressed genes (called regions of increased gene expression, or RIDGEs) have been identified in breast tissue and breast cancer tissue on human chromosome 11 . Furthermore, when several SAGE libraries are compared, differentially regulated genes can be identified. SAGE has already has been used successfully to identify differentially regulated genes in colon cancer cell lines and tumors ${ }^{78}$, pancreatic carcinoma ${ }^{79}, \mathrm{p} 53$-induced apoptosis ${ }^{80}$, and has led to the elucidation of the role of several genes in the cell cycle and malignant transformation ${ }^{81}$ ? .

\section{Principles of SAGE}

SAGE comprises a set of techniques, which allows the qualitative as well as quantitative analysis of a large number of genes expressed in a well-defined cell type or tissue. Three principles underlie the SAGE methodology: i) a short sequence tag (10 to 14 basepairs) contains sufficient information to uniquely identify a transcript provided that the tag is obtained from a unique position within each transcript; ii) sequence tags can be linked together to from long serial molecules that can be cloned and sequenced; and iii) quantitation of the number of times a particular tag is observed provides the expression level of the corresponding transcript.

To illustrate the first principle, and if one considers that there are 4 nucleotides ( $A, C, G$ and $T$ ) of which DNA consists, $4^{10}$ or $1,048,576$ different DNA sequences of 10 nucleotides can be generated. In addition to the requirement that these tags should be derived from a defined position within a cDNA and considering that the human genome is capable of expressing at least 30,000 genes, it is easily understood that at least in theory, each expressed gene can be uniquely represented by a tag.

When one is able to serially clone and sequence these 10 basepair tags, one is able to generate tag databases that not only show which tag is expressed in a certain cell type or tissue, but also to what extent, i.e. how many of the same tag are expressed. In other words, 
serial analysis allows the qualitative as well as quantitative analysis of gene expression. As with serial communication by computers, where information is transmitted as a continuous string of data, serial analysis of sequence tags requires a way to establish the register and boundaries for each tag. It should be noted that the third principle requires the elimination of PCR bias in the SAGE protocol, which is achieved by the use of a suppressive PCR, and the elimination of duplicate dimers by the SAGE software.

\subsubsection{Overview of the SAGE technique}

The conventional SAGE protocol used in the course of our studies can be obtained from http:/www.sagenet.org/. It requires a minimum of $2 \mu \mathrm{g}$ mRA as input material. SAGE also requires that mRNA, which only represents 1-5\% of the total RNA content of the cell, is isolated from a well-defined source which is contaminated as little as possible with unwanted tissue or cells. Usually, when isolating RNA from cultured cells, more than 100 $\mu \mathrm{g}$ of total RNA, or $1-5 \mu \mathrm{g}$ mRNA can relatively easily be recovered. When isolating RNA from small samples, usually less than $100 \mathrm{ng}$ of $\mathrm{mRNA}$ is recovered, requiring adaptations to the conventional SAGE protocol, which have resulted in the MicroSAGE protocol and are described in Chaprer $3^{83}$. An overview of the protocol is described below which applies to SAGE in general.

After having isolated mRNA in the first step (FIGURE 2: for detailed overview see FIGURE 1, CHAPTER 2), mRNA is converted to double-stranded CDNA with a biotinylated oligo$\mathrm{dT}_{\mathrm{I2}-\mathrm{I} 8}$. The cDNA is then digested with the endonuclease NLIII or 'anchoring enzyme' (AE) which recognizes the four basepair sequence CATG and theoretically occurs once every 256 basepairs. The AE marks the fixed position in the cDNA from which the SAGE tag will be derived. After digestion with the $A E$, the sample will be split in two pools and the 3' cDNA ends can be captured with streptavidin-coated magnetic beads (in the case of conventional SAGE) or can be immobilized in streptavidin-coated $0.2 \mathrm{ml}$ tubes (in the case of MicroSAGE; see Chapter 3 for details). In our case NlaIII was used as an AE, but in fact any fourcutter that generates a ssDNA overhang after digestion is suitable for SAGE.

In the next step, one half of the 3 ' cDNA ends will be ligated to linker A, containing a sequence complementary to Primer $A$ and a NlaIII overhang, whereas the other half of the 3 ' ends will be ligated to linker $B$, which likewise has a sequence complementary to Primer B. Both linkers are blocked at their blunt ends by a 3' modification on the lower strand, in order to prevent tail-to-tail ligation of linkers in the following steps. In addition, both linkers have a recognition sequence for a Type IIS endonuclease, BsmFI, which digests DNA 10 to 14 basepairs downstream of its recognition sequence, and is referred to as the 'tagging enzyme' (TE). Another TE that has been used in the past is Fok ${ }^{74}$. After having ligated the linkers to the 3' cDNA ends, a digestion with the TE is performed, essentially liberating the linker and a stretch of 10 to 14 basepairs from the 5 end of the captured cDNA.

The liberated tags and their attached linker are then isolated, and the single-stranded overhang generated by the TE is filled in with a DNA polymerase in order to generate blunt ends. The two pools $A$ and $B$ are then combined and ligated to essentially form synthetic DNA molecules that contain two tags (ditags) tail to tail, flanked by recognition sequences for the $A E$ and linkers. These ligation products can then be amplified by means of a suppressive PCR. Theoretically, only molecules that consist of the combination linker A-ditag- 


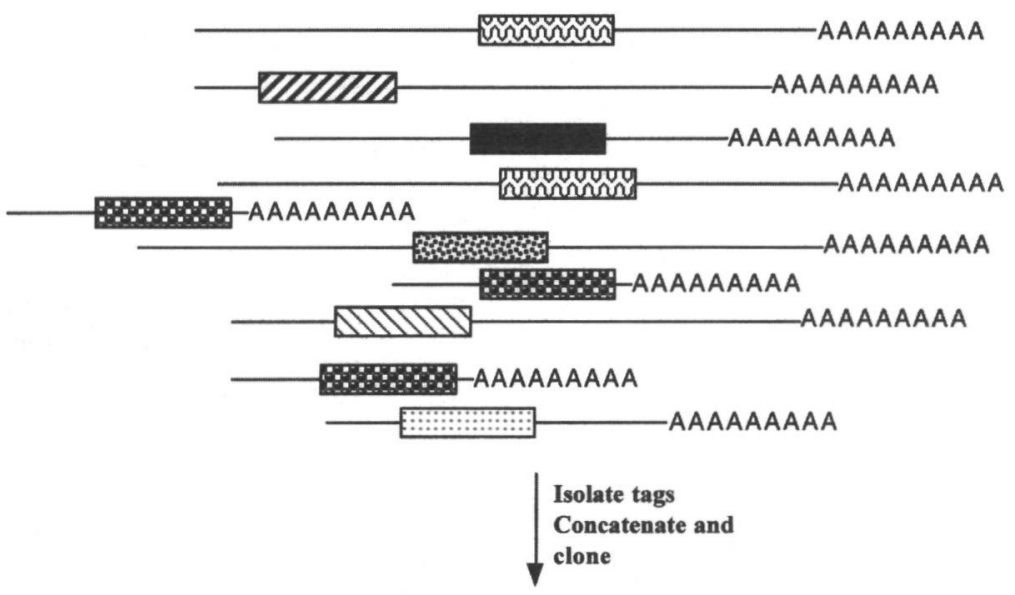

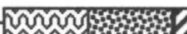

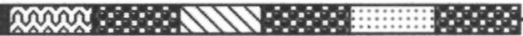

FIGURE 2 The principle of SAGE. Seven species of mRNA are represented by a total of 10 tags.

Boxes indicate individual tags.

linker B can be successfully amplified, as combinations of linker A-ditag-linker A and linker B-ditag-linker B will not be able to anneal with its primers because both complementary ends of the same molecule will anneal, or be suppressed during amplification, leading to the formation of loops. The suppressive nature of the PCR also diminishes the chance of generating duplicate dimers.

After amplification, PCR products are run on a polyacrylamide gel and the PCR product is separated from other molecules in the PCR mix. Since the linkers are approx. 40 base- 
pairs long, and the ditags between the linkers are approx. 25 basepairs long, resulting PCR products are expected to be around 100 to 110 basepairs in length (FIGURE 3). These products are isolated from the gel, digested with the $\mathrm{AE}$ to release ditags from their linkers, and once again the samples are run on a polyacrylamide gel to separate ditags of \pm 25 basepairs from the linkers (FIGURE 4). The ditags are isolated from the gel and then combined in one ligation reaction with a high amount of units of DNA ligase, in order to serially arrange ditags in concatemers, long DNA molecules consisting of ligated ditags that are punctuated by the recognition sequence of the $\mathrm{AE}$.

These concatemers are once again run on a polyacrylamide gel, and concatemers between 400 and 1000 basepairs are isolated from the gel (FIGURE 5). These concatemers are in turn ligated into a suitable sequence vector, transformed into bacteria, and resulting individual colonies are subjected to a colony PCR with vector-specific primers that flank the inserts. Only PCR products that match the length of isolated concatemers will be used for sequencing with a vector-specific primer. If the average length of the cloned concatemers is 400 basepairs and an average ditag length of 25 basepairs is assumed, there are approximately $400 / 25=16$ ditags per clone, representing $16 \times 2=32$ tags, or transcripts. Considering that at least 10,000 tags need to be sequenced in order to get a general transcription profile of genes that are expressed at relatively high levels in a given cell type or tissue, it is easily understood that sequencing is preferably done on a high-throughput automated sequencer, especially since there is still some contamination of linkers and duplicate ditags. Sequences that have been collected from the sequencer are then processed with SAGE2000 software, which is able to extract tags from raw (i.e. plain text) sequence data, and data can be analyzed further.

\subsubsection{Analysis and verification of SAGE data}

As indicated in the previous paragraph, SAGE2000 software is capable of generating tags from raw plan text sequence data. During that process, linker contamination is discarded from the data, and duplicate ditags are excluded. The occurrence of identical ditags (or dimers) is highly unlikely under the conditions used in the SAGE protocol, since the use of a Type IIS tagging enzyme, which cuts randomly between 10 to 14 basepairs from its recognition sequence, virtually eliminates this possibility. The software is also capable of generating tag frequency tables, which show how many of each tag are expressed in the sample of interest. In addition, it is capable of extracting tags from known mRNA and DNA sequences in the public database GenBank, in principle allowing a comparison of the tags generated in the project with those that are known from GenBank. By comparing the data with tags extracted from known databases, one can identify tags that are not matched in the database, which may represent unknown genes or variants of known genes. Data output files may be saved in a format that allows the use of database management software for further analysis of the data.

The software also allows one to make a comparison of two different SAGE libraries, enabling one to identify differentially regulated genes. SAGE2000 performs a Monte Carlo simulation, where a number of statistical tests are performed under the null hypothesis that there is no difference between the libraries to be compared. Furthermore, it allows the calculation of the power of the test for each differentially expressed tag. Other software tools have been developed independently, most notably the Tag to Gene screening facility, called SAGEmap, at the National Center for Biotechnology Information (NCBI; http://www.ncbi.nlm.nih.gov/SAGE). Here a tag sequence can be compared to a database 


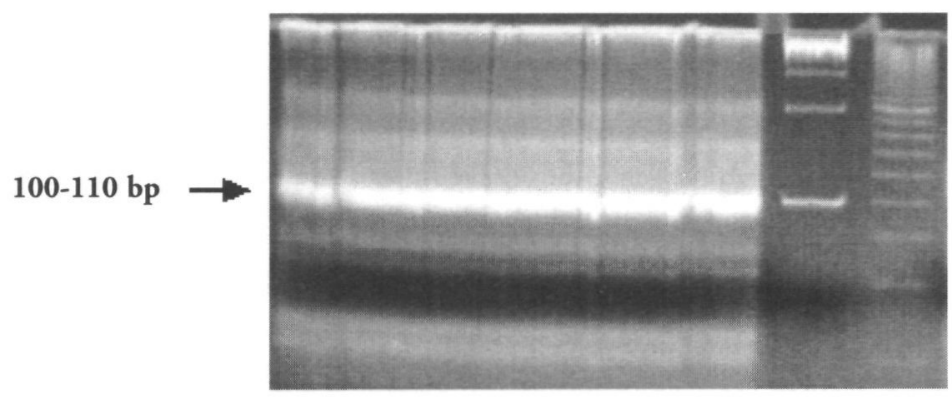

FIGURE 3 Linker-ditag molecules of 100-110 bps, after amplification by PCR. Samples were run on a $12 \%$ polyacrylamide gel, and DNA was stained with ethidiumbromide and visualized with ultraviolet light.

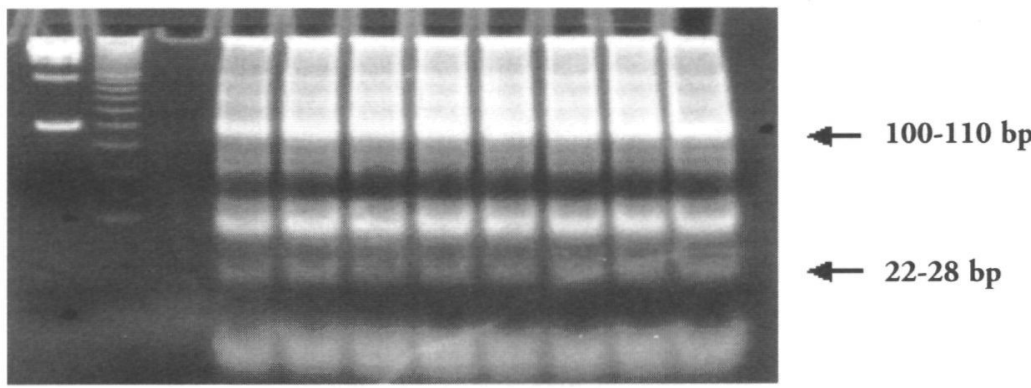

FIGURE 4 Linker-ditags digested with the anchoring enzyme. Note that digestion is incomplete. Samples were run on a $12 \%$ polyacrylamide gel, and DNA was stained with ethidiumbromide and visualized with ultraviolet light.

\section{Region to isolate for cloning}

FIGURE 5 Concatemers of ditags have been run on a $8 \%$ polyacrylamide gel, and DNA was stained with ethidiumbromide and visualized with ultraviolet light. The region in the boxed area contains concatemers of approx. 600 to $>1000$ bps for cloning into a suitable sequencing vector.

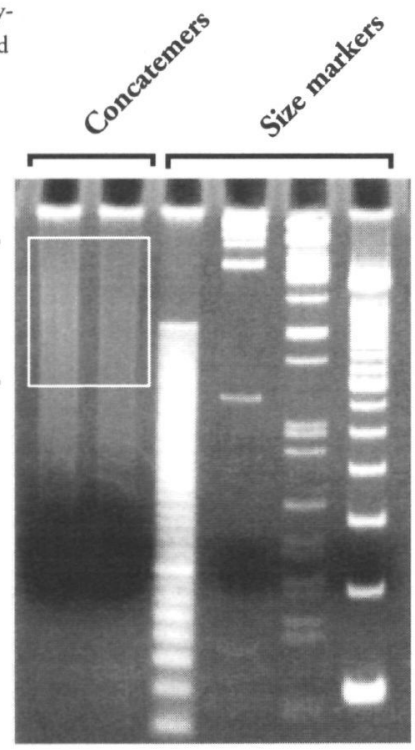


of tags extracted from UniGene, a database where genes and ESTs have been clustered on the basis of nucleotide sequence identity, thus allowing the assignment of tags to genes that would otherwise have been ignored in the screening with the SAGE2000 software ${ }^{\text {A4 }}$. A problem with the approach by the NCBI is that it only allows the processing of one tag at a time. Fortunately, however, the SAGEmap databases are available for download to the public, in a format that allows further analysis in database- and statistical software. Other tools that allow the analysis of tag databases include eSAGE ${ }^{8}$, PowerSAGE and ExProView ${ }^{87}$, all of which substitute or are complementary to the SAGE2000 software package. Additional online tools include USAGE ${ }^{88}$ and the Human Transcriptome Map (HTM; http://bioinfo.amc.uva.nl/HTM/), for both of which special algorithms were developed. The HTM also allows the identification chromosomal regions of increased gene expression (RIDGEs), possibly unveiling unusual transcriptional activity in certain chromosomal regions during disease or development ${ }^{77}$.

A recently developed online software tool is PubGene, which is a literature network of human genes for high-throughput analysis of gene expression ${ }^{89}$. Explicit and implicit biomedical knowledge was extracted from publicly available gene and text databases to create a gene-to-gene co-citation network. The associations between genes have been annotated by linking them to terms from the medical subject heading (MeSH) index and terms from the gene ontology (GO) database. In other words, a literature network has been created that can be browsed with a MeSH term or GO term (referring to a single gene), thus enabling one to identify other genes that have been mentioned in the same abstract. Although it does not allow sequence information (or SAGE tags) as input, it may reveal relevant genetic networks. Likewise, cluster analysis can be performed using commercial software packages like Statistica, SPSS or SAS, essentially with the same goal.

Although many different software tools are available for the analysis of SAGE data, the ultimate experiment to verify (differential) gene expression is a good, classical method like Northern blotting. Internal standards can be used, such as $\beta$-Actin, a radiolabelled probe for which can be included in the hybridization experiments. A problem may be that even metabolic or structural genes can be differentially regulated. A generally accepted method is to load an equal amount of total RNA (usually 5 to $10 \mu \mathrm{g}$ ) from the two samples alongside each other, and then to verify equal loading either by methylene blue staining, or by the hybridization of ribosomal RNA with specific probes. If only the tag is known, i.e. the associated gene is of unknown nature, radiolabelled oligonucleotides derived from SAGE tags can be used as a probe, the problem here being that tags are very small molecules and are difficult to hybridize at standard conditions. Other techniques that can be used for SAGE data verification are the RNase protection assay and quantitative PCR, provided that the gene associated with the tag of interest is known.

\subsubsection{How to isolate an unknown gene with an unknown SAGE tag}

Initially, tags that could not be assigned to a known gene through GenBank were used to screen cDNA libraries from the tissues or cell cultures the SAGE libraries were derived from ${ }^{74,80}$. As with Northern blotting, the problem here is that SAGE tags are very short, and that hybridization with these tags is hampered by high background, a high number of false positives and low hybridization efficiency. This problem can partially be overcome by the inclusion of the tagging enzyme recognition sequence at the 5 ' end of the tag, as this sequence should also be present in the target cDNA. The increase of hybridization efficiency however, is marginal, and may prove useless when dealing with AT-rich sequences. 
The optımal hybridization (or annealıng) temperature of an oligonucleotide can be calculated with the following formula $T_{m}=815+166\left(\log _{10}\left[\mathrm{Na}^{+}\right]\right)+041$ (fraction $\mathrm{G}+\mathrm{C}$ )$600 / N$, where $N$ is the length of the oligonucleonide, which may be of help in determining the hybridization temperature and correct monovalent ion concentrations in the hybridization mix, as ionic strength has a profound influence on hybridization efficiency ${ }^{\circ 0}$ In general, however, this type of fishing expeditions using SAGE tags is rare, suggesting that it is difficult to implement

A better approach may be to use a PCR-based method, similar to rapid amplification of 3 ' cDNA ends (3'-RACE) Several of these have been described, rapid analysis of unknown SAGE tag PCR (RAST-PCR) being the first ever to be reported ${ }^{\prime 1}$ It uses an oligo-dT 24 with a $5^{\prime} \mathrm{M} 13$ tail for the synthesis of single stranded cDNA from total RNA, and in the following PCR an M13 primer as a reverse primer and a primer derived from the SAGE tag, as a forward The primer derived from the SAGE tag consists of the SAGE tag itself and at its 5' end the anchoring enzyme sequence and five additional inosine nucleotides (dITPs) to increase annealing temperatures durıng PCR Another method has been reported which essentially is a modification of the RAST-SAGE protocol One involves the use of anchored oligo-dT primers instead of an M13 primer for the amplificanion of the cDNA product, potentially reducing background ${ }^{22}$, whereas others simply have performed a 3 '-RACE, only using a slightly adapted, SAGE tag-derived forward primer ${ }^{93}$

An elegant approach called Reverse SAGE has not (yet) been published, but the protocol can be found at the SAGE homepage, http //www sagenet org/ It can be considered an adaptation of the SAGE protocol, as the protocol is the same up to the stage where linkers are ligated Furthermore, RNA is converted to single stranded cDNA with an oligo-dT and an additional stretch of 16 to 20 nucleotides and is biotinylated at the 5' end, in order to facilitate a PCR with forward primers that match a part of the used linker, the anchoring enzyme sequence and the SAGE tag of interest, and a reverse primer that matches the 5 ' sequence of the oligo used to synthesize the cDNA It is in essence also an adaptation of 3'-RACE Problems that are being resolved with this strategy is the use of short oligonucleotides as forward primers and that in the first few cycles of the PCR primer annealing is sub-optimal With this method, primers can directly and completely anneal with their template, allowing more robust amplification The resulung PCR product can be cloned, sequenced and perhaps used as a probe Furthermore, sequence information can be used to design new primers to facilitate 5'-RACE

\section{Adaptations of the SAGE protocol}

Obviously, as with any publıshed technique, adaptations and varıants of SAGE have been developed MicroSAGE was a welcome addition to the repertoire, as it allows the analysis of gene expression of small samples, even on the micro-anatomic scale, in the range of only a few nanograms of $\mathrm{mRNA}{ }^{\text {H1 }}$ The procedure is performed in a single streptavidin-coated tube, dimınıshing loss of material, while the amount of PCR cycles was slightly increased to get hıgher yıelds of amplified ditags Otherwise the technique is essentially the same as conventional SAGE In Chapter 3 a study is described in which MicroSAGE was successfully used to analyze gene expression in human epidermal samples SAGE-Lite and PCRSAGE were also developed in order to apply SAGE to small samples, and both are essentıally the same technıque ${ }^{94}$ "s In both methods, input CDNA is amplified by PCR, which poses a problem with regard to the reliability of the SAGE data The introduced PCR bias in SAGE-Lite and PCR-SAGE may result in an under- or overestimation of the expression 
of a gene, which makes MicroSAGE a more attractive way of analyzing small samples.

Many other, smaller adaptations have been made, from a heating step of ditag concatemers prior to ligation into a sequencing vector to increase cloning efficiency and insert length ${ }^{96}$, to the use of biotinylated primers in the ditag amplification step so that linkers can be removed with streptavidin-coated tubes or magnetic beads in order to also increase cloning efficiency and insert length, as well as to decrease linker contamination in the data ${ }^{97}$. As SAGE comprises a fairly complex set of techniques, many other small adaptations have been made that will not be included in this Introduction. Furthermore, new adaptations are being published on a regular basis, as well as new software tools that allow the analysis of SAGE data.

\subsubsection{Advantages and problems of SAGE}

One of the most obvious advantages of SAGE is that it allows for both quantitative as well as qualitative analysis of gene expression. In contrast to the micro-array technology, which is based on known genes and sequences, it also allows for the identification of unknown genes. In fact, it does not even require prior knowledge of genes of interest. The most compelling feature of SAGE is that it allows the simultaneous analysis of literally hundreds of thousands of transcripts, making it perhaps the most comprehensive technique for genome-wide gene expression analysis. It has also been proven to be a very sensitive technique, as it even detects transcripts with low expression levels, and it can detect relatively small differences in expression levels between two samples ${ }^{\circ}$. Furthermore, it is based on a relatively simple set of molecular techniques that can easily be applied in a standard laboratory ${ }^{74}$.

However, it is this simple set of techniques where also the greatest dangers lie. It is absolutely essential that input material is pure, and that several steps are carried out at low temperatures. Furthermore, during the course of the project described in this thesis, it became increasingly clear that enzymes and chemicals used in the protocol must be of the highest quality. It has been pointed out that a shift in favor of a high tag GC content occurs when isolated ditags have been handled at room temperature ${ }^{\mathrm{g} 9}$. Although this was presented as a flaw in the SAGE protocol, it should be noted that many biases are introduced by human error, and are not necessarily inherent to the technique. Furthermore, statistical algorithms have been developed to diminish the effect of inherent biases like sampling error, sequencing error, nonuniqueness, and nonrandomness of tags ${ }^{100}$.

Sequencing errors do occur, since input sequences are single-pass sequences. This porentially causes the incorporation of tags in the analysis that are irrelevant. It has been estimated that about $5 \%$ of sequenced tags are in fact unreliable because of these errors ${ }^{100}$. However, this also depends on the sequence chemistry, the sequencing system used and the length of the sequence read. Although sequencing errors can never be overcome, using more reliable sequencing methods can reduce them.

Another problem in the analysis of SAGE data is that some tags are derived from common repeats, most notably Alu sequences, which are dispersed throughout the genome, and are often present in 3'-UTRs of mRNAs. Moreover, differential splicing and polyadenylation may incorrectly over- or underrate the role of a differentially expressed gene. The three problems mentioned here may greatly be reduced once the sequence of the human genome has been analyzed with the help of improved algorithms for the detection of genes in genomic sequences ${ }^{101}$. 
Many of the disadvantages of SAGE have already been overcome by adapting steps in the protocol, or introducing modified protocols like MicroSAGE. There are still problems to tackle, but many can and will be marginalized by the use of new or adapted technology, and the introduction of software that takes advantage of newly developed algorithms will hopefully reduce the effect of inherent biases.

\section{The human skin}

The research described in this thesis concerns the application of SAGE human cultured keratinocytes and isolated human epidermis. In order to get better insight in the function and structure of the skin, epidermal gene expression and the culture model used in this project, an overview will be given in the following paragraphs regarding human skin and epidermal keratinocyte biology. As the human epidermis is fairly complex from a cell biological point of view, and in fact is a mixture of proliferating and terminally differentiating keratinocytes, knowledge with regard to its biology also leads to a better understanding of gene expression profiles generated by SAGE.

FIGURE 6 The structure of the human skin. The dermis is covered by the epidermis, which in turn consists of several layers. The stratum basale contains the proliferating keratinocytes which supply the overlying layer, the stratum spinosum, with cells that start to differentiate toward granule-containing keratinocytes that mostly reside in the stratum granulosum. The granules contain important

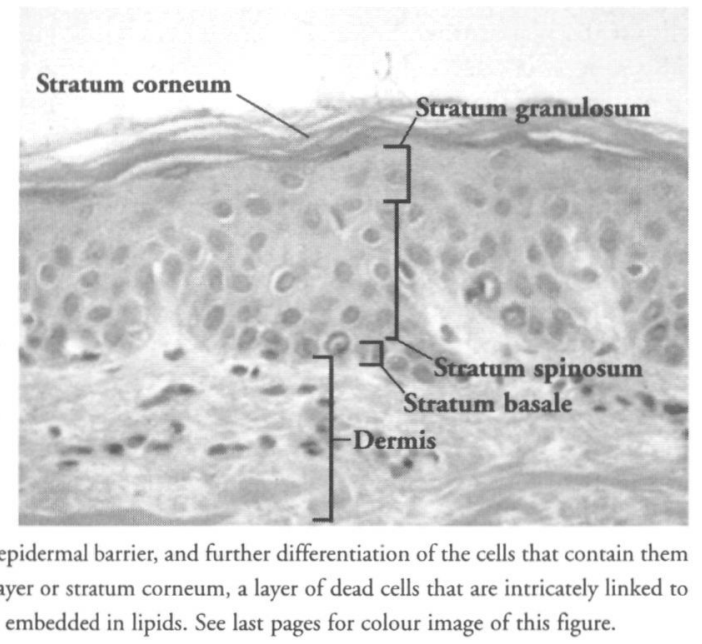

proteins involved in the formation of the epidermal barrier, and further differentiation of the cells that contain them results in the formation of the cornified layer or stratum corneum, a layer of dead cells that are intricately linked to each other through a network of proteins embedded in lipids. See last pages for colour image of this figure.

\section{Structure and function}

Human skin consists of a stratified, cellular epidermis, and an underlying dermis or connective tissue. The outermost skin layer, the epidermis, is a terminally differentiating, stratified squamous epithelium. The keratinocyte is the cell type that makes up to $95 \%$ of the epidermis and undergoes a complex and carefully choreographed program of differentiation. During this process, keratinocytes move from the epidermal basement membrane towards the skin surface and form four well-defined morphologically distinct layers (FIGURE 6). The stratum basale, which is the inner cell layer of the epidermis, consists of a single layer of relatively undifferentiated cells that are anchored to the basal lamina via hemidesmosomal junctions. This layer contains the basal cells, which provides a continuous supply of new cells to repopulate the epidermis. This layer also contains the pigment- 
forming cells or melanocytes, secretory cells that inject pigment granules into epidermal and hair cells. There is now evidence that the true epidermal stem cells reside in the bulge region of hair follicles ${ }^{102}{ }^{103}$, and migrate outward of the hair follicle into the basal compartment of the epidermis, where transient amplifying cells with limited proliferative capacity supply the upper layers with new cells. Immediately above the basal cell layer, the epibasal keratinocytes form the stratum spinosum or spinous layer. The keratinocytes in this layer interact with adjacent keratinocytes through desmosomal connections, forming a stabilizing network. Upward from the stratum spinosum is the stratum granulosum or granular layer, which contain all of the organelles and activities typically associated with intact cellular metabolic function, indicating that they are still living as they approach the final steps in differentiation. The cytoplasm of cells in the upper, spinous layer and granular layer contain lamellar granules. These granules discharge their lipid components into the intercellular space and play an important role in the barrier function and intercellular cohesion within the outermost layer of the epidermis: the stratum corneum. In this cell layer, the keratinocytes have lost their nuclei and cytoplasmic organelles, and are now called corneocytes. They become flattened and the keratin filaments are cross-linked by the formation of disulfide bonds under the influence of fillagrin, the protein component of the keratohyalin granules in the granular layer. Corneocytes have an insoluble cornified envelope within the plasma membrane, formed by cross-linking of the soluble protein involucrin. This process is catalyzed by a specific epidermal transglutaminase that is synthesized in the upper layers of the stratum spinosum. The terminal stage of the transition process is desquamation involving degradation of the lipids in the intercellular spaces and loss of residual intercellular desmosomal connections. The continuous renewal and ourward and upward migration of keratinocytes requires a strict balance between cell proliferation and differentiation ${ }^{104}$.

Since the skin encloses our whole body, the most obvious function of the skin is to form a border between the inside and the environment. It provides a protective barrier against microorganisms, chemicals from the environment, and prevents the loss of fluids. In addition, the skin is also important in the regulation of body temperature, protecting against trauma, including ultravioler (UV) radiation, and it contains several types of sensory receptors, which detect the incoming stimuli of, for example, touch, pain, itch, and temperature changes. Beside these functions, the skin plays a major role in immunological host defense. Without this protective mechanism, we would be extremely susceptible to infection by pathogenic microorganisms. The role of the keratinocytes in immunological defense became apparent only recently, when it was realized that keratinocytes could produce a variery of growth factors, chemoactractants, and cytokines. Furthermore, keratinocytes express receptors for many polypeptide factors, respond to autocrine stimulation, and also respond to the signals produced by the immune system ${ }^{105}{ }^{107}$. The immunological function of the keratinocyte is enhanced in pathological conditions, e.g. during wound healing, or in allergic and inflammatory reactions. For example, when the skin is injured, the tissue damage induces an inflammatory response that destroys harmful microorganisms and parasites, inacrivates and dilutes toxins, and rejects foreign bodies. The cells of the immune system, including the phagocytes (polymorphonuclear leukocytes and macrophages) and the lymphocytes (primarily $T$ and $B$ cells), play an important role in this process and function in close collaboration with molecular components of the keratinocyte, which include complement, acute-phase proteins, antibodies, and cytokines. During this reaction, the keratinocytes become 'activated': they produce and respond to growth factors and cytokines, become migratory, and can produce components of the basement membrane. The importance of signaling between keratinocytes and lymphocytes is 
apparent in the cutaneous disorders that involve both of these cell types, including psoriasis, delayed-type hypersensitıvity, cutaneous T-cell lymphoma and atopic dermatitis ${ }^{100}$

\section{The keratinocyte culture model}

In our laboratory a submerged keratınocyte culture model has been establıshed previously ${ }^{109} 110$ The model shows low proliferative activity and allows early differentiation of keratinocytes in the absence of growth factors, or in the presence of factors that induce differentiation The induction of early differentiation is demonstrated by the fact that early differentiation markers, especially cytokeratıns 1 and 10 , are expressed in these cultures, but that those that indicate late differentiation, like filaggrin and lonicrin, are virtually absent Interestingly, when cultures are supplemented with fetal calf serum, a phenotype is observed that closely mimics the inflammatory skin disease psoriasis, as assessed by the change to high expression levels of cytokeratin 16, skın-derived antileukoprotease (SKALP/elafin), transglutamınase and involucrın "11 Furthermore, flow-cytometric analysis showed sustained hyperproliferation of keratinocytes when induced with fetal calf serum, as opposed to a low proliferative rate seen in normally differentiating keratinocytes

Interestingly, the expression of SKALP/elafin is upregulated during psoriasis, and its expression can be modulated by cytokines and growth factors that are known to play important roles in inflammatory skin disease Especially TNF- $\alpha$ is capable of upregulating these molecules through a pathway involving the mitogen activated protein (MAP) kinase famıly member c-Jun termınal kınase (JNK-1) 112 Another protease inhıbitor, secretory leukoprotease inhibitor (SLPI) is also regulated by TNF- $\alpha$ in this culture model, and is believed to play an important role in antımıcrobial defense Like SKALP/elafin, it is also upregulated in cultures with a regenerative, psoriatic phenotype ${ }^{113}$ The transcription factor CCAAT-enhancer binding protein alpha (C/EBP- $\alpha)$ is associated with differentiation in human epidermis In the submerged culture system the expression of C/EBP- $\alpha$ is indeed also associated with nuclei of differentiated keratinocytes, further strengthening the assumption that the model system used throughout the studies described in this thesis can mimick early differentiation ${ }^{114}$ The culture system has also successfully been used to test and investigate the effect of detergents on keratinocytes ${ }^{115}$

Taken together, these data indicate that the culture model is suitable for the investigation of cellular responses and pathways that also play a pivotal role in keratinocytes in vivo Furthermore, the use of a culture system allows large-scale gene expression analysis, as bioactive substances can be added to the medium and their effect can be assessed by the use of technologies such as SAGE and the cDNA micro-array technology This is especially important because gene expression profiling of live epidermis is far from easy since biopsies are small, requiring possibly interfering adaptations of the aforementioned techniques The culture model, however, enables one to obtain a maximum amount of sample with little hassle, and does not inflict harm on a volunteer or patient, nor does it require adaptatıons to any protocol In this thesis, the culture system described above was used in all studies involving in vitro experiments, and its expression profile was compared to that of epidermal biopsies that were subjected to MicroSAGE, the results of which are discussed in CHAPTERS 2 and 3 
For the differentiation process to proceed, 1 e to produce a normal epidermis with all its functions and the competence to respond to tissue damage, a wide variety of genes must be activated or inactivated at correct time and place As pointed out before, gene regulation can be controlled at multuple levels These include regulation of the rate of mRNA synthesis, the rate of decay (or stability) of the mRNA product, the rate at which the mRNA is translated, and the stability of the protein product Many of the keratinocyte genes discovered so far are at least regulated on the transcriptional level by transcription factors These DNA binding proteins are targets of signal transduction pathways that convert extra- or intracelluiar stimuli via protein cascades to the nucleus and the gene Several transcription factors involved in the regulation of epidermal genes have already been idenufied

During embryogenesis, the human ectoderm forms the outermost cell layer of the embryo, and later in development gives rise to the formation of a neural tube and human epidermis through a carefully directed process of gene expression ${ }^{116}$ Human mesodermal embryonic cells and later in development dermal fibroblasts, express growth factors which in turn stimulate growth and differentiation of overlying ectoderm or embryonic epidermis ${ }^{11}$ ? Early embryonic keratinocyte development also involves $\beta_{1}$-integrin, which together with keratinocyte growth factor (KGF) and fibroblast growth factor 10 (FGF 10), produced by the underlying cells, and epidermal growth factor (EGF), produced by both the underlying cells as well as keratinocytes themselves, set off an intricate gene expression program that leads to proliferation and differentiation of keratinocytes $\boldsymbol{\beta}_{1}$-integrin is essential for this differentiation, as the transition of 'simple' epithelial cells with a debilitating mutation in $\beta_{1}$-integrin, but expressing keratins 8, 18 and 19 , to basal epidermal cells expressing cytokeratins 5 and 14 does not occur in vitro ${ }^{118}$, although differentiation is observed to some extent when these cells are cultured on dead, de-epidermized human dermis in the presence of aforementioned growth factors ${ }^{119}$ It has been shown that keratins 8 and 18 are controlled by the activator protemn 1 (AP1), a homo- or heterodımer of jun, fos or activating transcription factors (ATFs) They bind to the 12-O-tetradecanoylphorbol-13acetate (TPA) responsive element (TRE) that is present in many keratunocyte genes Various studies indicate that AP1 factors play an important role in the regulation of cell differentiation and cell death in the epidermis ${ }^{120} 121$ In addition, it has been shown that keratın 18 is regulated by the oncogenic Ras signalıng pathway through transcription from closely spaced Ets and AP1 transcription factor binding sites ${ }^{122}$ Other data suggest that expression of keratins 8 and 18 is regulated by AP1 through EGF and retinoic acid ${ }^{123} 124$, the latter of which binds the nuclear receptors retinoic acid receptor (RAR) and retinoic $X$ receptor (RXR) and mediate transcription directly through the cis-acting retinoic acid response element (RARE) or by binding other transcription factors Both classes of retinoic acid receptors consist of three family members, $\alpha, \beta$, and $\gamma$ RAR preferentially binds all trans-retinoic acid, whereas RXR preferentially binds 9-cis-retınoic acid, and they primarily exist as RAR- $\gamma /$ RXR- $\alpha$ heterodimers in human keratinocytes ${ }^{121} 125127$ Adult condıtional knockour mice have shown that RXR- $\alpha$ plays an important role in hair morphogenesis, and in functional state suppresses hyperproliferation of the epidermis as measured by keratin 16 expression which is usually associated with this condition ${ }^{128} 129$ Completely knocking out RXR- $\alpha$ in mice results in embryonic death, which only shows how important this transcription factor is during development ${ }^{130}$, whereas RAR- $\gamma$ knockout mice show severe growth retardation and other abnormalities ${ }^{131}$ Using dominant negative constructs of RAR- $\alpha$, it has been shown that the skin of transgenic mice loses its barrier func- 
ton ${ }^{132}$, and when a dominant negative RXR- $\alpha$ mutant is targeted to suprabasal layers of the epidermis, proliferation of basal keratinocytes is disturbed ${ }^{133}$ When administering the retinoic acid antagonist AGN 193109 to female pregnant mice late in gestation (14 days post cottum), keratınocyte differentiation and hair follicle maturation is delayed, indicating an important role for retinoic acid receptors in the development and homeostasis of the epidermis and its appendages ${ }^{134}$ The vitamin D receptor 15 , like RAR and RXR, a nuclear receptor that induces differentiation of keratinocytes in culture, but in vivo seems to suppress differentiation, although low doses of vitamin $D$ induce proliferation in vitro Vitamin D receptors are expressed in all layers of the epidermis, but it is believed that its ligand vitamin $D$ does not exclusively mediate its effect through the receptor, but also through protein kunase $C$ and G-protenn coupled receptors, among others ${ }^{121}$ It has been shown that ablation of the vitamin $\mathrm{D}$ receptor in mice leads to an abnormal mineral metabolism and loss of hairs ${ }^{135}$

The role of Wnt/wingless and Notch signaling in the development of the epidermis and Its appendages has become apparent only recently, mainly through experiments using the mouse and rat as a model system The Wnt pathway is involved in mesenchymal-epidermal interactions during embryogenesis ${ }^{136}$, and is important in harr follicle development ${ }^{15-}$ Lef-1, a transcription factor that is regulated through the Wnt pathway, requires activated $\beta$-catenin for its activity, and is involved in the transcription of har-specific keratins and controls hair differentiation, but not in epidermal differentiation ${ }^{13 \mathrm{H}}$ Mice that have a condicional, inhibitory mutation in $\beta$-catenin fail to form normal hatr follicles 139 Furthermore, there is evidence that $\beta$-catenin is directly regulated by Wnt signals, and upon activation binds either Lef- 1 or the transcription factor T cell factor 3 (Tcf3), depending on which factor is expressed Tcf3 can also act independently from $\beta$-catenın, and represses terminal keratınocyte differentiation, which may explain its presence in the bulge of hair follicles where the pluripotent epidermal stem cells reside Although other transcription factors may play a role in Wnt signaling, it is clear that $\beta$-catenin, Lef-I and TcF3 play central roles It is unclear however, which Wnt family members are involved in the activation of the aforementioned transcription factors in the human epidermis 138 Signalıng via the heterodimeric Notch receptor appears to play an important role in keratınocyte differentiation, and is modulated by proteins of the Fringe family, which show a differentiation-dependent expression in human epidermis, and which are in turn regulated by retınoic acid ${ }^{140}$ Deltal, a ligand of the Notch receptor, is exclusively expressed in the basal layers of the epidermis, whereas the receptor is expressed throughout all layers ${ }^{141}$ Keratınocytes that have an inhibitıng mutation in the Notch receptor show deralled expression of differentiation markers, while intact Notch signaling is required for keratinocye growth arrest and differentiation ${ }^{142}$ There is also evidence that Deltal independently from Notch regulates the migration of transient amplifying keratinocytes ${ }^{143}$

From the above it is clear that various transcription factors are activated in response to stımulı from outsıde the cell to form the epidermis and to direct keratınocyte differentiation APl transcription factors are expressed in a differentiation dependent manner and the activity of APl transcription factors is regulated by the distribution of these factors in cytoplasm and nucleus and by phosphorylation AP1 transcription factors are targets of the protein kınase $C$ signal transduction pathway that precedes the mitogen-activated protein kunase (MAPK) signal transduction cascades ${ }^{144}$ Well-known enhancers of keratinocyte differentiation are phorbol esters like TPA, which operate, at least in part, via activation of this parhway Other factors that regulate APl activity are ultraviolet (UV) light and tissue trauma ${ }^{145} 146$ A closely related transcription factor family is the AP2 family, the members 
of which are, contrary to AP1, encoded as monomers of $52 \mathrm{kDa}$. Genes that are activated by $A P 2$, as with $A P 1$, include genes that are expressed under different conditions (i.e. proliferation and differentiation), including cytokeratins $5^{147}, 14^{148}$, and $16^{149}$, involucrin ${ }^{150}$, and transglutaminase type ${ }^{151}$. Another transcription factor that has been implicated in the regulation of several keratinocyte genes is Sp1. Like AP1 and AP2, Spl activates transcription of epidermal genes belonging to different functional protein classes (cornified envelope precursors and keratins) and having different patterns of regulation (basal cells, hyperproliferative cells, disease states) during differentiation. Previous studies have identified a number of keratinocyre genes that are regulated by Spl, including transglutaminase type 3, involucrin, and cytokeratins $3,5,16$, and $18^{120}{ }^{121}$. Other transcription factors that have been identified and found to play a role in the regulation of keratinocyte gene expression, are Ets transcription factors 152153 , POU domain proteins ${ }^{154}{ }^{155}$, ATF family members of CRE binding proteins ${ }^{156}, \mathrm{C} / \mathrm{EBPs}$, and NF- $\mathrm{kB}$. The C/EBPs comprise a family of transcription factors that are involved in the regulation of many genes. As mentioned earlier, C/EBP- $\alpha$ is found in the suprabasal layers of the epidermis and in human keratinocytes induced to differentiate, and a role for $\mathrm{C} / \mathrm{EBPs}$ in the regulation of differentiation has been suggested ${ }^{114}$. NF- $\kappa B$ is a transcription factor that is activated when it is released from the protein with which it forms a complex, I-KB. Upon release, NF-kB migrates from the cytoplasm to the nucleus, where it binds to the promoter of its target genes, for example cytokeratin $6 \mathrm{~b}$. Recently, Seitz et al. suggested a role for NF-KB in the switch from proliferation to growth arrest and differentiation of suprabasal keratinocytes ${ }^{157} 158$. Furthermore, a role for this transcription factor has been suggested in the anti-apoptotic phenotype of keratinocytes ${ }^{159}$.

Taken together, keratinocytes contain various members of different transcription factor families. These are needed to drive the basal transcriptional activity, but are also active in the process of cellular signaling. During this process, transcription factors integrate the signals that are relayed from the cell surface via signal transduction pathways. In addition, the members of different transcription factor families can participate as multimeric assemblies to regulate gene expression by binding to nearby binding sites. This process is called combinatorial regulation ${ }^{160}$. This allows differential activation of transcription and is based on the particular transcription factor binding sites present in the target gene, whether the transcription factor is in an inactive or active form, and the abundance of each factor. This makes it possible for keratinocytes to activate a diversity of genes at correct time and place, and control the pathways that regulate cell proliferation and differentiation in order to produce a normal epidermis with all its functions ${ }^{161}{ }^{164}$.

In the skin, these pathways play an important role in the regulation of local inflammatory processes following UV-irradiation, disordered proliferation and differentration of keratinocytes in psoriatic epidermis, or in the process of wound healing. Most of the signal transduction pathways start at the level of the plasma membrane, where extracellular signals, such as hormones, cyrokines, and growth factors, bind to their cognate cell surface receptors. This leads, depending on the incoming signal, to the liberation of second messengers and the activation of protein kinases such as the CAMP-and cGMP-dependent protein kinases and protein kinase $C$. Three well establıshed pathways are known to operate in cutaneous tissues. The adenylate cyclase/cAMP-dependent protein kinase signaling system is involved in hyperproliferative epidermal conditions, such as psoriasis ${ }^{165} 166$. The phospholipase $\mathrm{C} /$ proteın kunase $\mathrm{C}$ ( $\mathrm{PKC}$ ) system, which is activated upon binding of ligands to their cognate receptors, activates an intracellular phospholipase $\mathrm{C}$ that hydrolyses membrane phospholipıds, the products of whıch serve as a second messenger: diacylglycerol 
(DAG) activates PKC ${ }^{167}$ and inositol-1,4,5-triphosphate $\left(\mathrm{IP}_{3}\right)$ ıncreases the concentration of intracellular free calcium by binding to a specific receptor at the endoplasmatic reticulum ${ }^{168}$, this pathway plays an important role in the response to stımulı such as EGF and platelet-derived growith factor (PDGF) ${ }^{169}$ A third pathway that is important in keratinocytes is the one that activates receptor tyrosine kunases, which through a process of autophosphorilation in their cytoplasmic domain, become activated by after binding of polypeptide hormones that control metabolism, cell growth, and cell differentiation ${ }^{170}$, effectively inıtıatıng a signaling cascade involving proteins with Src homology 2 (SH2) domains ${ }^{171}$

Apart from housekeeping genes, such as those involved in metabolism and protein synthesis, various unique gene families are being expressed in the human epıdermis, most notably cytokeratıns They are the main buldıng blocks of the keratınocyte cytoskeleton Interestingly, the expression of these proteins depends on the state of keratınocyte differerentiation As indicated before, the expression of cytokeratins 5 and 14 is associated with undıfferentiated, proliferatıng keratınocytes at the basal membrane, while cytkeratıns 1 and 10 are associated with differentiation and are thus expressed in suprabasal layers of the epidermıs ${ }^{121}$ Cytokeratıns 6,16 and 17 are expressed in keratınocytes durıng inflammatory conditions and wound healing ${ }^{172}$ It has been demonstrated that cytokeratin 6 is also regulated by TNF- $\alpha$ and interleukun 1 (IL1) during inflammatıon ${ }^{173}{ }^{174}$, thus explaining its involvement in stress response There is evidence that cytokeratin 16 is involved in cytoskeletal rearrangement in order to facilitate keratınocyte migration during wound healing ' Other genes that are associated with differentiation are filaggrin, lonicrin and involucrin, all of which are part of the cornified layer, and are expressed in the outer layers of the epidermis The formation of the cornifued envelope involves the cross-linking actuvity, and therefore the expression, of transglutamınase ${ }^{176}$ It is clear that, in addition to the expression of structural genes that are involved in physical and chemical barrier formation, keratınocytes need to express genes that provide some level of defense against microbes $A$ large number of genes that are involved in antımıcrobial defense are expressed in the epidermis, among others defensıns ${ }^{177}$, cystatın $A^{178181}$, SLPI, SKALP/elafin ${ }^{182} 185$ and various cytokines ${ }^{1 \text { th }}$ Some of these are under the direct regulation of inflammatory cytokines through MAP kinase pathways or NF- $k B$, whereas cystatın A is constitutively expressed and is even present in the cornified envelope Another member of the cystatin family for which a clear role has yet to be established, cystatın E/M, will be discussed in more detall in CHAPTER 6

It is obvious that these genes are under the control of pathways that direct normal differentiation and stress response, via cell-cell interactions and via stimulation by extracellular signals, respectively These signals are thus relayed from the outside to the inside of the cell The relay of the signal from the plasma membrane to the transcription machinery can be very complex, and usually involves varıous mediators such as kunases, phosphorylases or just adaptor proteins or chaperones However, not all signal transduction pathways necessarily result in induction of gene expression, as is illustrated by the existence of a cellular suicidal machinery that can be invoked by extracellular signals Many members of the tumor necrosis factor (TNF) family of cytokines have the unique ability to initiate either a transcriptional program, or execute cell death in target cells through serial activation of proteases, which in turn destroy the cell in a carefully choreographed manner As two of these family members have played a pivotal role in the course of the studies that led to this thesis, the following chapter will be devoted to the pathways they initiate 
Already three decades ago lymphotoxin (LT) and TNF- $\alpha$ were identified as inducers of cell lysis in tumor cells ${ }^{187}{ }^{180}$. Their cDNAs were cloned ${ }^{189}{ }^{190}$, and soon it appeared that LT- $\alpha$ and TNF share homology and that they are members of a superfamily of genes that now is being referred to as the TNF family. Although both molecules were initially thought to be effective in the treatment of cancers, systemic toxicity prevented them from being used as anticancer drugs. Interestingly, their cognate receptors also share considerable homology, thus also belonging to a TNF receptor (TNFR) superfamily ${ }^{191}$. In recent years both superfamilies have grown, as database mining identified many ESTs that show considerable homology with the archetypical family members ${ }^{192}$. To date, 17 TNF homologues and 26 TNF receptor homologues have been identified ${ }^{123}$. The discovery of the TNF and TNFR superfamilies has spawned an enormous amount of research into the biology of these molecules, as they play seemingly disparate roles in host defense, inflammation, apoptosis, autoimmunity and organogenesis. TNF homologues are type II transmembrane proteins that exist as trimers on the plasma membrane, and can bind their trimerized cognate type I receptors on the target cell. TNF family members can act in two modes: they can induce a transcriptional program, or they can trigger a signaling cascade in which a set of cysteine proteases, called caspases, are serially activated and eventually cause the cell to die ${ }^{194}{ }^{195}$. Both pathways are important to the research described in this thesis, as both TNF- $\alpha$ signaling and the induction of apoptosis by TRAIL are being investigated. An overview of the pathways is depicted in FIGURE 7.

TNF- $\alpha$ binds to one of its receptors, TNF-RI or TNF-RII, through which it can either induce apoptosis in the presence of the protein synthesis inhibitor cycloheximide, or initiate a signaling cascade that results in a transcriptional response respectively. TNF-RU contains a modest cytoplasmic domain harboring a docking site for adapter proteins, the death domain (DD). Likewise, death receptors 4 and 5 (DR4, DR5) for TRAIL also contain these domains. In the case of TNF-RI, the death domain can bind, through homotypic interaction, with TNFR-associated death domain containing protein (TRADD) ${ }^{196}$, which in turn can bind Fas-associated death domain containing protein (FADD) ${ }^{197}$. DR4 and DR5 directly bind to FADD upon TRAIL engagement to the receptors ${ }^{198}{ }^{200}$. FADD can recruit caspase- 8 or -10 to the receptor through homotypic interaction of the 'death effector domain' (DED) in FADD and the prodomain of the caspases ${ }^{201}{ }^{204}$, essentially forming a complex that is also referred to as death-inducing signaling complex (DISC) ${ }^{205}$. These proximal caspases are believed to be proteolytically activated by induced proximity through the binding of the ligand to its receptor ${ }^{206} 207$, and are cleaved into two subunits that together can form an active heterodimer ${ }^{208} 209$. Acrivated caspases-8 and -10 then either proteolytically activate downstream effector caspases like caspases $-3,-6$ or -7 , or, in the case of caspase- 8 , cleave and thereby activate the caspase- 8 specific substrate $\mathrm{Bcl}$ homology 3 interacting domain and death agonist protein (Bid), which in turn translocates to the mitochondria ${ }^{210}$. There it associates with Bcl-2 antagonist and killer (Bak) or Bcl-2 associated $X$ protein (Bax), triggering cytochrome $c$ release from the inner membrane and the activation of apoptotic protein activating factor 1 (Apaf-1) which in turn triggers the activation of caspase- 9 and the subsequent activation of executioner caspases 205211212 . Caspase- 9 interacts with Apaf-1 through another domain, structurally related to DD and $\mathrm{DED}$, called caspase recruitment domain, or CARD ${ }^{213}$. Where DDs and DEDs play pivotal roles in death receptor signaling, CARDs seem to be playing an important role in apoptotic pathways via the mitochondrion and in inflammation 211215 . 


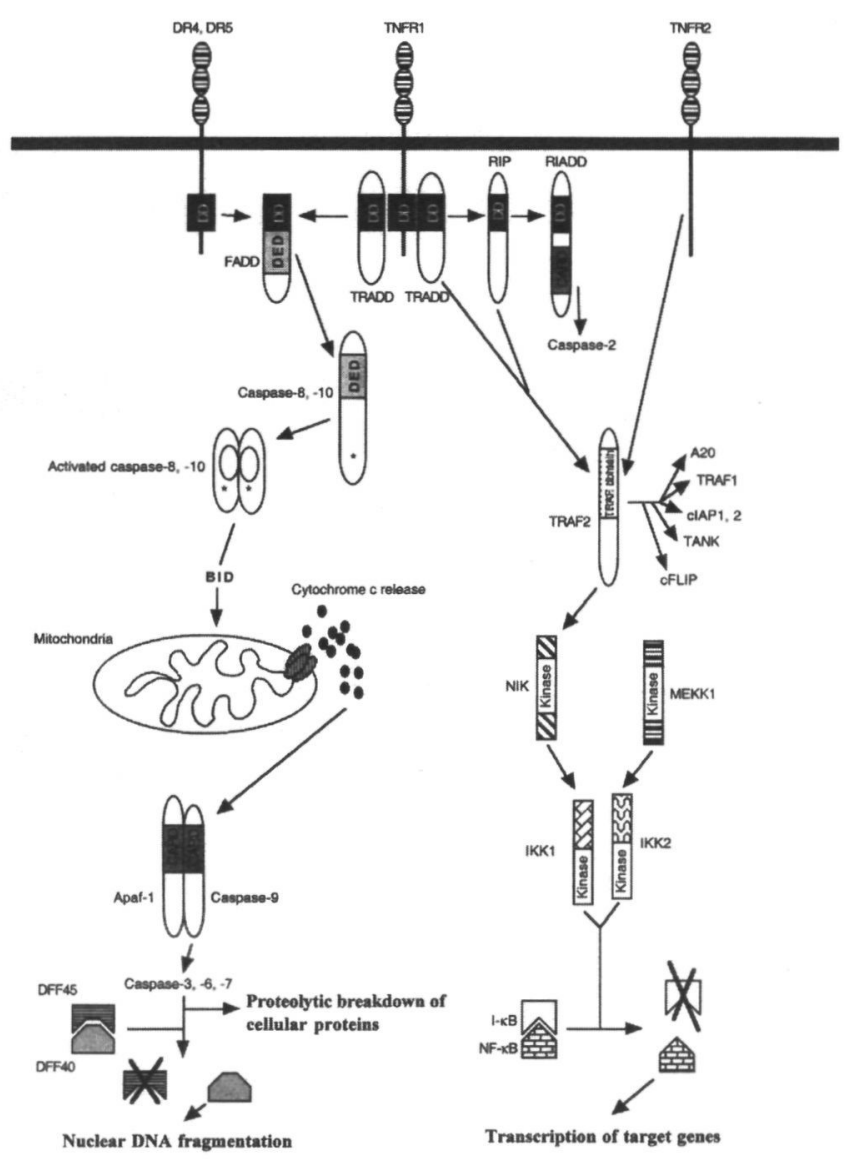

FIGURE 7 Regulation of caspase activation and the NF-kB activating signaling cascade by the TNF receptors and death receptors 4 and 5. For details, see text.

The so-called short-prodomain executioner caspases-3, -6 and -7 relay the apoptotic signal, but their roles are distinct during apoptotic demolition of the cell ${ }^{216}$. They are able to inactivate cellular protein substrates by proteolysis. Famous examples are the cyclindependent kinase inhibitors CDKN1A and CDKN1B, the degradation of which by caspase- 3 causes the accumulation of cyclin-dependent kinase 2 (CDK2), which is associated with apoptosis in endothelial cells ${ }^{217}$. Other substrates include lamins for caspase- $6{ }^{218}$, and the human DNA fragmentation factor of $45 \mathrm{kDa}$ (DFF45) for caspase-3, which is the inhibitor of the DNA endonuclease DNA fragmentation factor of $40 \mathrm{kDa}$ (DFF40), responsible for the typical internucleosomal DNA fragmentation seen during apoptosis ${ }^{219-222}$. Widespread destruction of the cellular structure and its biochemical machinery, as well as the targeted, efficient degradation of its genetic material causes typical morphological 
changes that are associated with programmed cell death, such as membrane blebbing, cellular shrinking and nuclear condensation ${ }^{223}$.

TNF- $\alpha$ usually only induces apoptosis in target cells in the presence of protein synthesis inhibitor cycloheximide, and there is evidence that the apoptotic response is enhanced by TNF-RII. It is as yet unclear how TNF-RII influences this process, although it has been hypothesized that TNF-RII may facilitate TNF- $\alpha$ binding to TNF-RI ${ }^{195}$, but it requires TRAF2 ${ }^{224}$. TNF-RII is most probably involved in inflammatory processes, as it does not contain a DD, but is able to bind TNF receptor-associated factors (TRAFs), which are known mediators of inflammatory stimuli 225226 . TRAIL, on the other hand, is known for its selective killing of transformed cells and tumor cells, and primarily functions as an inducer of apoptosis through DR4 and DR5 ${ }^{227}{ }^{230}$. Two other receptors, decoy receptors 1 and 2 (DcR1, DcR2) also bind TRAIL but do not contain a complete DD in their cytoplasmic tails, and are not able to relay an apoptotic signal. It is believed that they confer resistance to TRAIL-induced apoptosis in healthy cells by simply binding TRAIL, thus effectively modulating the apoptotic response. Interestingly, DcR2 is also able to activate the pro-survival NF-kB pathway in target cells, adding some insurance against apoprosis ${ }^{231} 2 "$.

TNF-RI and -RII can also induce pathways that lead to induction of gene expression, most notably in inflammation ${ }^{19}$. These pathways are either regulated primarily through the MAP kinase cascade, which eventually leads to the activation of JNK, and ultimately the transcription factor AP1, or via a pathway that induces the transcription factor NF- $k B$. Both pathways are involved in stress response, inflammation in particular. How exactly JNK is activated is not entirely clear, but there is evidence that MAP kinase activating death domain protein (MADD) can induce the MAP kinase pathway after interaction with the death domain of TNF-RI ${ }^{2 * 4}$, whereas TRAF2 plays a key role in signaling induced by TNF-RII, which results in the activation of JNK ${ }^{235}$. Other TRAF family members also induce a variety of pathways and can form heterodimers, indicating that they have largely overlapping functions in a wide variety of tissues ${ }^{236}$.

One of the best-studied pathways initiated by TNF- $\alpha$ is probably the NF- $\kappa B$ activation kinase cascade. The mode of activation involves various scaffold and adapter proteins that associate with the cytoplasmic tail of one of the TNF receptors, like receptor-interacting proteins (RIPs) ${ }^{237}{ }^{239}$, TRADD ${ }^{1 \%}, 197$, RIP-associated ICH1/CED3-homologous protein with death domain (RIADD) ${ }^{240}{ }^{241}$, and TRAFs, and these are, upon ligation of the ligand to the extracellular domain of the TNF receptors, able to activate NF- $\mathrm{kB}$ inducing kinase (NIK) and MAP/ERK kinase kinase 1 (MEKK1). These latter kinases in turn phosphorylate and thereby activate I-KB kinases 1 and 2 (IKK1, IKK2), which phosphorylate

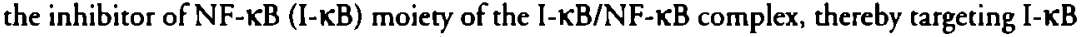
for degradation by the proteasome ${ }^{242250}$. Upon liberation of NF- $\kappa B$, it translocates to the nucleus and induces the transcription of various genes, including cytokines, chemokines, adhesion molecules and cytoprotective molecules. Interestingly, many genes that are believed to be transcribed through NF-KB activity are not necessarily immediately expressed. Indeed, there is evidence that genes are expressed in two waves, where some promoters of genes are immediately accessible to NF- $\mathrm{KB}$, whereas others are accessible at a later stage and require additional regulation through MAP kinase signaling cascades ${ }^{251}$ that may be initiated through the same receptor as the NF-KB inducing pathway.

Studies with knock-out mice have shown the importance of TNF signaling molecules in human epidermal biology. TNF-RI appears to be the main mediator of TNF- $\alpha$ induced 
cutaneous inflammation, and plays an important role in the induction of apoptosis of epidermal cells in response to UV irradiation as delerion of this receptor could suppress apoptosis ${ }^{252} 253$. Interestingly, TNF- $\alpha$ ablation renders mice resistant to skin carcinogenesis, ruling out TNF- $\alpha$ as the main mediator of apoptosis to prevent carcinogenesis ${ }^{254}$. TNF-RII appears to play a role in Langerhans cell migration and contact hypersensitivity ${ }^{25}$. Mice that have a debilitating mutation in $\mathrm{I}-\kappa \mathrm{B} \alpha$, one of the subunits of $\mathrm{I}-\kappa \mathrm{B}$, have a sustained NF-KB response and suffer from widespread dermatitis ${ }^{256}$. Knocking out IKKl in mice results in abnormalities in the skeleton and the skin ${ }^{25}$. When knocking out both IKKl and IKK2, NF-KB activity is completely lacking ${ }^{258}$. IKK3, a relative of IKK1 and IKK2, is involved in the human skin disease X-linked incontinentia pigmenti, as was discovered by knocking out IKK3 in the mouse, which shows similar pathology. The disease is characterized by keratinocyte hyperproliferation, skin inflammation, hyperkeratosis, and increased apoptosis ${ }^{259} 260$. The importance of TNF signaling in skin development and homeostasis is further exemplified by the fact that the anhydrotic ectodysplasin protein (EDA) and its receptors (EDAR and X-linked EDAR), are TNF and TNFR superfamily members respectively, and inhibiting mutations in any of these genes lead to a disease in mice similar to human anhydrotic ectodermal displasia ${ }^{261}{ }^{262}$. Nerve growth factor receptor (NGFR) signaling is involved in the regulation of hair follicle development, as mice that lack NGFR, which is also a member of the TNFR superfamily, display an accelerated hair development, suggesting a negative regulatory role for NGFR in that process ${ }^{263}$. Furthermore, TNF- $\alpha$ can be shed from the plasma mebrane, such that it is soluble. The enzyme responsible for shedding, TNF- $\alpha$ converting enzyme (TACE), is essential for mouse development, indicating that ectodomain shedding is required for normal development (264).

The role for TNF- $\alpha$ and its homologues in skin development is evident from the above, as well as its role in inflammation. TNF- $\alpha$ is also induced during microbial challenge by lipopolysaccharide (LPS) and therefore plays an important role during host defense ${ }^{265}$. Furthermore, therapy specifically aimed at the inhibition of TNF- $\alpha$ in the treatment of psoriasis points to a key role in this inflammatory skin condition, although many other cytokines play a seemingly important role in this disease. Psoriasis is characterized by keratinocyte hyperproliferation and a leukocyte infiltrate. The cause of this disease is not clearly understood, although both genetic and environmental elements are implicated 266267. TNF- $\alpha$ is not genetically linked to the disease ${ }^{268}$, but patients treated with antibodies agaunst TNF- $\alpha$ (known as Infliximab) show strong clinical improvement ${ }^{269}{ }^{271}$. In another approach, TNF- $\alpha$ was inhibited by the use of a human recombinant soluble TNF-RII linked to the Fc portion of IgG1 (commercially available as Etanercept), which acts as a competitive inhibitor of TNF- $\alpha$ binding to its receptors. Again, psoriasis patients treated with this molecule show promising clinical improvement ${ }^{269} 272273$. Clearly, TNF- $\alpha$ and its family members play important roles in the development and homeostasis of the epidermis, and the effectiveness of anti-TNF- $\alpha$ therapy underscores its importance in disease as well. An in-deprh analysis of the effects of TNF- $\alpha$ on keratinocyte gene expression is therefore warranted, and the results are presented and discussed in Chapter 2. 


\section{Aim of this thesis}

The rapid development of molecular biology and genetics over the last two decades has culminated in the application of large-scale, high-throughput technologies in order to investigate genome-wide gene expression profiles and differential gene expression. Combined with the development of bioinformatics tools, these technologies provide a powerful means to elucidate general transcriptional programs underlying normal development and disease. Serial Analysis of Gene Expression (SAGE) is a gene expression profiling rool that can be applied relatively easily as it is based on classic molecular-biological techniques. Previous studies have already shown great promise, as SAGE has lead to the identification of new genes, new markers for certain types of cancer, and even the elucidation of certain biochemical pathways. Furthermore, SAGE has helped in determining the role of known genes of which the function was previously unknown. SAGE therefore is an excellent tool to investigate gene expression profiles in human cultured keratinocytes under various conditions in vitro, because sufficient material can be obtained for use in the conventional SAGE protocol. Furthermore, adaptations of the SAGE protocol have made it possible to use small samples like skin biopsies as input material, thus enabling gene expression profiling in vivo.

The aim of this thesis is to apply SAGE to keratinocytes, to investigate differential gene expression in vitro in response to an inflammatory stimulus to keratinocytes, to investigate differential gene expression in vivo in normal epidermis and epidermal premalignant tumors, and to establish a partial transcriptome of epidermal keratinocytes. Furthermore, unknown genes or genes that were previously not known to be expressed in keratinocytes or epidermis, were identified and characterized. In Chapter 2 the effect of TNF- $\alpha$ is investigated in a submerged culture model that allows differentiation. TNF- $\alpha$ is an important mediator of inflammatory response in psoriasis, and is able to trigger a psoriasis-like stress response in vitro. In order to investigate differential gene expression in premalignant actinic keratosis and unaffected and normal epidermis, biopsies were taken and epidermis isolated from the biopsies. As presented in Chapter 3, a modified SAGE protocol, MicroSAGE, was used to perform large-scale gene expression profiling and analysis of isolated epidermis, identifying clusters of genes that are relevant to premalignant skin tumor biology. In Chapter 4 a partial transcriptome of human epidermal keratinocytes is presented, and gene expression in the keratinocyte culture model and in human epidermis are compared.

These gene expression studies have led to the identification of genes of which the function in keratinocytes is obscure, or have not been described in human keratinocyres. One of these genes, encoding the TNF homologue TRAIL, has the capability of inducing apoptosis in transformed cells and tumor cells. In Chapter 5 the effect of TRAIL on both differentiated and undifferentiated keratinocytes is described, and it is shown that keratinocytes are sensitive to TRAIL and do not exhibit internucleosomal DNA fragmentation during apoptosis. Another gene that has been subjected to thorough research is cystatin $\mathrm{E} / \mathrm{M}$, of which the expression in keratinocytes was initially established by SAGE. In Chapter 6 its expression pattern is investigated, and it is shown that the expression of cystatin E/M is limited to human keratinocytes and epidermis. Finally, in CHAPTER 7 the work presented in this thesis is summarized and discussed. 
1. Shenk T. Transcriptional control regions. nucleotide sequence requirements for inttation by RNA polymerase II and III. Curr Top Microbıol Immunol 1981;93:25-46

2. McKnight SL, Kungsbury R. Transcriptional control signals of a eukaryotic protein-coding gene Science 1982;217(4557):316-24.

3. Dynan WS, Tjian R Control of eukaryotic messenger RNA synthesis by sequence-specific DNA- bunding proteins. Nature 1985;316(6031)·774-8.

4. Sawadogo M, Roeder RG Energy requirement for specific transcription untuation by the human RNA polymerase II system. J Biol Chem 1984;259(8):5321-6.

5. Weiss SB. Enzymatıc incorporation of ribonucleotide triphosphates into the interpolynucleoride linkages of ribonuclesc acid Proc Nad Acad Sa U S A 1960;46:1020-1030.

6. Brent R. Repression of transcription in yeast Cell 1985,42(1).3-4.

7. Guarente L. Yeast promoters: positive and negative elements Cell 1984,36(4):799-800.

8. Iyer V, Struhl K. Absolute mRNA levels and transcripuonal initiation rates in Saccharomyces cerevisiae Proc Natl Acad Sci U S A 1996;93(11).5208-12.

9. Darnell JE, Jr RNA. Scl Am 1985;253(4):68-78

10 Erdmann VA, Barciszewska MZ, Hochberg A, de Groor N, Barciszewska J Regulatory RNAs Cell Mol Life Sci 2001;58(7)·960-77.

11 Busch H, Reddy R, Rothblum L, Choi YC. SnRNAs, snRNPs, and RNA processing Annu Rev Biochem 1982;51:617-54.

12 Gıdonı D, Dynan WS, Tjian R. Multıple specific contacts between a mammalian rranscription factor and its cognate promoters Nature 1984,312(5993):409-13.

13 Hastıngs ML, Krainer AR. Pre-mRNA splicing in the new millennıum Curr Opın Cell Bıol 2001;13(3):302-9.

14. Nevins JR The pathway of eukaryotic mRNA formation Annu Rev Biochem 1983;52 441-66

15 Proudfoot N. Connecting transcruption to messenger RNA processing. Trends Biochem Sct 2000;25(6):290-3

16 Bırnstiel ML, Busslınger M, Strub K. Transcripuon termination and $3^{\prime}$ processing: the end is in site' Cell 1985;41(2) 349-59
17. Keesey JK, Jr., Bıgelıs R, Fink GR. The product of the hus 4 gene cluster in Saccharomyces cerevisıae. A trifuncuonal polypeptide. J Biol Chem 1979;254(15):7427-33.

18. Sherman F, Stewart JW. Mutations Altering Initiation of Translation of Yeast Iso-1-Cytochrome c; Contrasts Between the Eucaryotic and Procaryotic Inirnation Process. In: Strathern JN, Jones EW, Broach JR, editors. The Molecular Biology of the Yeast Saccharomyces, Metabolism and Gene Expression. Cold Spring Harbor, N. Y.: Cold Sprıng Harbor Laboratory; 1982 p. 301-333

19. Bosse LH, Gonzalez-Garcia M, Postema CE, Ding L, Lindsten T, Turka LA, et al. bcl-x, a bel-2-related gene that functions as a dominant regulator of apoptotic cell death Cell 1993;74(4) ·597-608.

20. Irmler $M$, Thome $M$, Hahne $M$, Schneider $P$, Hofmann K, Sreiner V, et al Inhibition of deach receptor signals by cellular FLIP Nature 1997;388(6638):190-5

21. Furuichı Y, Morgan M, Muthukrishnan S, Sharkin AJ Reovirus messenger RNA contauns a methylated, blocked 5 -termunal structure. m-7G(5')ppp(5')G-MpCp. Proc Nad Acad Seı U S A 1975,72(1):362-6

22. Adams JM, Cory S. Modified nucleosides and bızarre 5 -termını in mouse myeloma mRNA Narure 1975,255(5503):28-33.

23. Shatkin AJ, Manley JL. The ends of the affarr: capping and polyadenylation. Nat Struct Biol 2000;7(10) $838-42$

24. Jacob F, Monod J. Geneuc Regulatory Mechanisms in the Synthesis of Proteins J Mol Biol 1961;3:318-356.

25 Sprague GF, Jr, Blair LC, Thorner J. Cell interactions and regulation of cell type in the yeast Saccharomyces cerevisiae. Annu Rev Microbıol 1983;37:623-60.

26 Carballo E, Lai WS, Blackshear PJ Feedback inhibirion of macrophage tumor necrosis factor-alpha production by tristetraprolin. Science 1998;281 (5379):1001-5.

27 Dean JL. Wait R, Mahtan KR, Sully G, Clark AR, Saldarvala J. The 3' untranslated region of tumor necrosis factor alpha mRNA is a target of the mRNA-stabılızing factor HuR Mol Cell Bıol 2001;21(3):721-30 
28. Ming XF, Stoecklın G, Lu M, Looser R, Moronı $C$ Parallel and Independent Regulation of Incerleukun-3 mRNA Turnover by Phospharıdylınositol 3-Kinase and p38 Mitogen-Aativated Protein Kunase. Mol Cell Bıl 2001;21(17):5778-89

29. $\mathrm{Km} \mathrm{H}$, You S, Farris J, Foster LK, Foster DN Post-transcripuional inactivation of p53 in Immortalized murine embryo fibroblast cells. Oncogene 2001,20(25):3306-10.

30. D'Erchia A M, Pesole G. Tullo A, Saccone C, Sbisa E. Guinea pig p 53 mRNA. identification of new elements in coding and untranslated regions and their functional and evolutionary ımplicatuons. Genomıcs 1999;58(1):50-64.

31. Le, EP, Krebber H, Suver PA. Messenger RNAs are recruted for nuclear export during transcription Genes Dev 2001;15(14) -1771-82.

32. Gyga SP, Rochon Y, Franza BR, Aebersold R Correlation between ptotein and mRNA abundance in yeast.

Mol Cell Bıol 1999;19(3):1720-30.

33. Mendez R, Myers MG, Jr, White MF, Rhoads RE Stimulation of protein synthesis, cukaryotic translation iniuation factor $4 \mathrm{E}$ phosphorylation, and PHAS-I phosphorylation by insuln requires insulun receptor substrate 1 and phosphatidylinositol 3-kunase.

Mol Cell Bıol 1996;16(6):2857-64.

34 Muller HJ. Arrificial Transmutation of the Gene. Science 1927;46:84-87

35. Stadler Mutations in Barley Induced by X-Rays and Radium. Saence 1928;1 10:543-548

36 Signer R, Caspersson T, Hammarsten E. Molecular Shape and Size of Thymonucleic Acid. Nature 1938;141:122.

37 Watson JD, Crick FHC. Molecular Structure of Nuclesc Acids. A Structure for Deoxyribose Nucleic Acıd Nature 1953;171·737-738.

38. Chargaff E, Davidson JN. The nucleic acids: chemusiry and biology New York: Academuc Press, 1955.

39 Brachet J. Brochemical cytology. New York: Academic Press; 1957.

40 Caspersson TO Cell growth and cell function, a cyrochemical study. 1st ed.

New York: Norton; 1950

41 Crick FHC. On Protein Synthesis. Symp. Soc. Exp Bıol. 1958;12:548-555
42. Brenner S, Jacob F, Meselson M An Unstable Intermediare Carrying Information from Genes to Rubosomes for Prorein Synthesis Nature 1961,190:576-581.

43 Gros F, Huatt H, Gilbert W, Kurland CG, Rusebrough RW, Watson JD. Unstable Rubonucleic Acid Revealed by Pulse Labelling of Escherichı colı. Nature 1961;190:581-585.

44. Hall BD, Spiegelman S Sequence Complementaricy of T2 DNA and T2-Specific RNA Proc. Nat Acad. Sci 1961;47-137-146.

45. Alwine JC, Kemp DJ, Stark GR. Method for detection of specific RNAs in agarose gels by transfer to diazobenzyloxymethyl-paper and hybridization with DNA probes. Proc Natl Acad Sa U S A 1977;74(12)·5350-4.

46. Southern EM. Detection of specific sequences among DNA fragments separated by gel electrophoresis. J Mol Bıol 1975;98(3).503-17.

47. Melton DA, Krieg PA, Rebagliatı MR, Manıatıs T, Zinn K, Green MR. Efficient in vitro synthesis of bıologically active RNA and RNA hybridization probes from plasmids contaning a bacteriophage SP6 promoter. Nudesc Acids Ros 1984;12(18)-7035-56.

48 Prediger EA. Detection and quantitation of mRNAs using ribonuclesse protection assays. Methods Mol Biol 2001;160:495-505.

49. Lee SW, Tomasetto C, Sager R. Positive selecuon of candidate rumor-suppressor genes by subtractive hybridization Proc Natl Acad Sci U S A 1991,88(7).2825-9.

50 Kavathas P, Sukhatme VP, Herzenberg LA, Pames JR Isolation of the gene encoding the hurnan T-lymphocyte differentiation antugen Leu-2 (T8) by gene transfer and cDNA subtraction. Proc Natl Aad Scı U S A 1984;81(24).7688-92.

51 Chien Y, Becker DM, Lindsten T, Okamura $M$, Cohen DI, Davis MM. A third rype of munne T-cell receptor gene. Nature 1984;312(5989):31-5.

52. Wang $Z$, Brown DD. A gene expression screen Proc Natl Aad Scı U S A 1991;88(24):11505-9.

53. Diatchenko L, Lau YF, Campbell AP, Chenchik A, Moqadam F, Huang B, et al. Suppression subtractuve hybridization' 2 method for generatıng differentually regulated or tissuespecific cDNA probes and libraries Proc Natl Acad Scı U S A 1996;93(12):6025-30. 
54. Siebert PD, Chenchik A, Kellogg DE, Lukyanov KA, Lukyanov SA. An improved PCR method for walkung in uncloned genomic DNA. Nucleıc Acıds Res 1995;23(6).1087-8

55. Liang P, Pardee AB Differentıal display of eukaryotic messenger RNA by means of the polymerase chain reaction.

Science 1992,257(5072).967-71.

56 Welsh J, Chada K, Dalal SS, Cheng R, Ralph D, McClelland $M$ Arbitrarly primed PCR fingerprinting of RNA.

Nucleic Acids Res 1992;20(19):4965-70.

57 Liang P, Averboukh L, Pardee AB. Distribution and cloning of eukaryoric mRNAs by means of differential display. refinements and optimization.

Nuderc Acids Res 1993;21(14)·3269-75.

58 O'Garra A, Vieıra P Polymerase chan reaction for derection of cytolane gene expression. Curr Opın Immunol 1992,4(2) -211-5

59 Freeman WM, Walker SJ, Vrana KE. Quanutative RT-PCR: putfalls and potential. Biotechniques 1999,26(1) $112-22,124-5$.

60 Bustun SA. Absolute quantification of mRNA using real-rime reverse transcriprion polymerase chan reaction assays.

J Mol Endocrinol 2000;25(2)·169-93.

61 Adams MD, Soares MB, Kerlavage AR, Fields C. Venter JC Rapid cDNA sequencing (expressed sequence tags) from a directionally cloned human infent bran cDNA library. Nat Gener 1993;4(4):373-80.

62 Adams MD, Kerlavage AR, Fields C, Venter JC 3,400 new expressed sequence tags identify diversity of transcripis in human brain Nat Genet 1993;4(3):256-67.

63. Venter JC, Adams MD, Myers EW, LI PW, Mural RJ, Sucton GG, et al. The sequence of the human genome.

Science 2001;291(5507):1304-51.

64. Lander ES, Linton LM, Birren B, Nusbaum C, Zody MC, Baldwin J, et al Inttal sequencing and analysis of the human genome. Nature 2001;409(6822):860-921.

65 Brown PO, Botsteın D. Exploring the new world of the genome with DNA microarrays Nat Genet 1999;21(1 Suppl):33-7.

66. Lipshute RJ, Fodor SP, Gingeras TR Lockhart D]. High densıty synthetic oligonucleotide amays Nat Genet 1999,21(1 Suppl):20-4.
67. DeRisi JL, Iyer VR. Genomics and array technology. Curr Opin Oncol 1999,11(1).76-9.

68 Schena M, Shalon D, Davis RW, Brown PO Quantitative monitoring of gene expression patterns wich a complementary DNA microarray. Science 1995;270(5235):467-70

69 Fodor SP, Read JL, Pircung MC, Stryer L, Lu AT, Solas D. Lighi-directed, spatially addressable parallel chemical synchesis. Science 1991;251(4995):767-73.

70. Aebersold R, Rist B, Gygı SP. Quantıtative proteome analysis: methods and applicarions Ann N Y Acad Scı 2000;919·33-47.

71 Gygi SP, Rust B, Aebersold R. Measuring gene expression by quantitative proteome analysis Curr Opin Brocechnol 2000,11(4)·396-401.

72. Blackstock WP, Weır MP. Proteomics quanutative and physical mapping of cellular proteins. Trends Blotechnol 1999;17(3).121-7

73 Yates JR, 3rd. Mass spectrometry From genomics to proteomics. Trends Genet 2000;16(1) 5 -8

74. Velculescu VE, Zhang L, Vogelsteın B, Kinzler KW. Serıal analysis of gene expression Science 1995,270(5235):484-7.

75 Velculescu VE, Zhang L, Zhou W, Vogelstein J, Basrai MA, Bassett DE, Jr., et al. Characterization of the yeast transcriptome. Cell 1997;88(2).243-51

76. Velculescu VE, Madden SL, Zhang L, Lash AE, Yu J, Rago C, et al Analysıs of human transcriptomes. Nat Genet 1999,23(4).387-8.

77 Caron H, van Schaik B, van der Mee M, Baas F, Ruggins G, van Sluss P, et al. The human transcriptome map' clustering of highly expressed genes in chromosomal domans Science 2001;291(5507) -1289-92

78 Zhang L, Zhou W, Velculescu VE, Kern SE, Hruban RH, Hamilton SR, et al. Gene expression profiles in normal and cancer cells Science 1997;276(5316).1268-72.

79. Zhou W, Sokoll LJ, Bruzek DJ, Zhang L, Velculescu VE, Goldın SB, et al. Identifyıng markers for pancreauc cancer by gene expression analysis. Cancer Epidemıol Bıomarkers Prev 1998,7(2):109-12.

80. Polyak K, Xia Y, Zweier JL, Kınzler KW, Vogelstein B. A model for p53-ınduced apoptosis. Nature 1997;389(6648):300-5. 
81. He TC, Sparks AB, Rago C, Hermeking $H$, Zawel L, da Costa LT, et al. Identification of c-MYC as a target of the APC pathway. Science 1998,281(5382):1509-12.

82 Hermeking $H$, Lengauer C, Polyak $K$, He TC, Zhang $L$, Thuagalıngam $S$, et al. 14-3-3 sıgma is a p53-regulated inhibitor of G2/M progression. Mol Cell 1997;1(1):3-11.

83. Datson NA, van der Perk-de Jong J, van den Berg MP, de Kloet ER, Vreugdenhil E MicroSAGE. a modified procedure for serial analysis of gene expression in limited amounts of ussue. Nucleic Acids Res 1999;27(5) -1300-7.

84 Lash AE, Tolstoshev CM, Wagner $L$, Schuler GD, Strausberg RL, Ruggins GJ, et al. SAGEmap: a public gene expression resource. Genome Res 2000;10(7) -1051-60.

85. Margulies EH, Innis JW. eSAGE: managing and analysing dan generated with serial analysis of gene expression (SAGE) Bıoinformaucs 2000;16(7):650-1.

86 Man MZ, Wang X, Wang Y. POWER_SAGE comparing statistical tests for SAGE experiments Bioinformatics 2000;16(11):953-9

87. Larsson $M$, Stahl S, Uhlen $M$, Wennborg A. Expression profile vewer (ExProView). a software tool for transcriptome analysis. Genomics 2000;63(3):341-53.

88. van Kampen AH, van Schak BD, Pauws E, Michiels EM, Ruijter JM, Caron HN, et al. USAGE: a web-based approach rowards the analysis of SAGE dan. Serial Analysis of Gene Expression. Biounformatics 2000;16(10)-899-905

89 Jenssen TK, Laegreid A, Komorowskı J, Hovig E. A literature network of human genes for high-throughput analysis of gene expression. Nat Genet 2001;28(1)-21-8.

90. Sambrook J, Fritsch EF, Maniatis T. Molecular cloning ' a laboratory manual 2nd ed. Cold Spring Harbor, N.Y.. Cold Spring Harbor Laboratory; 1989.

91. van den Berg A, van der Leıj J, Popperna S. Serial analysis of gene expression rapid RT-PCR analysis of unknown SAGE tags. Nucleic Acids Res 1999;27(17):e17.

92. Chen JJ, Rowley JD, Wang SM. Generation of longer cDNA fragments from serial analysis of gene expression tags for gene identification Proc Natl Acad Scı U S A 2000;97(1) 349-53
93 Matsumura $H$, Nirasawa $S$, Terauchı $R$

Technıcal advance: transcript profilıng in rice (Oryza sariva L.) seedlings using serial analysis of gene expression (SAGE).

Plant J 1999;20(6) 719-26.

94 Netlson L, Andalibi A, Kang D, Coutufars C, Strauss JF, 3rd, Stanton JA, et al. Molecular phenorype of the human oocyre by PCR-SAGE. Genomics 2000;63(1):13-24.

95 Peters DG, Kassam AB, Yonas H, O'Hare EH, Ferrell RE, Brufsky AM Comprehensive transcript analyss in small quantities of mRNA by SAGE- lite.

Nucleıc Acids Ros 1999;27(24)-e39.

96 Kenzelmann M, Muhlemann K Substantially enhanced cloning efficiency of SAGE (Serial Analysis of Gene Expression) by adding a heatung step to the onginal protocol. Nucleic Acids Res 1999,27(3) 917-8

97 Powell J Enhanced concatemer cloning-a modification to the SAGE (Serıal Analysıs of Gene Expression) technique. Nucleıc Acids Res 1998;26(14) 3445-6

98 Velculescu VE, Vogelsten B, Kinzler KW. Analysing uncharted transcripromes with SAGE Trends Genet 2000;16(10):423-5

99 Margulies EH, Karda SL, Innis JW Identification and prevention of a GC content bias in SAGE libraries. Nucleic Acids Res 2001;29(12).E60-0.

100 Srollberg J, Urschirz J, Urban Z, Boyd CD. A quantitative evaluation of SAGE. Genome Res 2000;10(8):1241-8.

101. Pauws E, van Kampen AH, van de Graaf SA, de Viflder JJ, Ris-Stalpers C. Heterogeneity in polyadenylation cleavage sites in mammalian mRNA sequences: Implications for SAGE analysis. Nucleıc Acids Res $2001 ; 29(8): 1690-4$

102 Oshima H, Rochat A, Kedzıa C, Kobayashı K, Barrandon Y. Morphogenesis and renewal of har follicles from adult multipotent stem cells. Cell 2001;104(2) 233-45.

103 Taylor G, Lehrer MS, Jensen PJ, Sun TT, Lavker RM. Involvernent of follicular stem cells in forming not only the follicle but also the epidermıs. Cell 2000,102(4) 451-61

104 Eady RAJ, Leigh IM, Pope FM Anatomy and organization of human skun. In. Champion RH, Burton JL, Burns DA, Breathnach SM, editors. Textbook of Dermatology. 6th ed Oxford- Blackwell Science, 1998. p 37-111. 
105 Ansel J, Perry P, Brown J, Damm D, Phan T, Hart C, et al. Cytokune modulation of keraunocyte cyrokunes. J Invest Dermatol 1990;94(6 Suppl)·101S-107S

106 Kupper TS. Immune and inflammarory processes in cutaneous tussues. Mechanısms and speculations.

J Clin Invest 1990;86(6):1783-9.

107. Willarns IR, Kupper TS. Immunity at the surface: homeostatic mechanisms of the skun Immune system

Lıfe SeI 1996,58(18).1485-507.

108 Archer CB. Functions of the skın

In. Champion RH, Burron JL, Burns DA,

Breathnach SM, editors. Textbook of

Dermatology. 6th ed.

Oxford- Blackwell Science; 1998. p 113-122

109. van Russen F, van Erp PE, de Jongh GJ, Boezeman JB, van de Kerkhof PC, Schalkwijk J. Cell kunetic characterization of growth arrest in cultured human keratinocyres.

J Cell Seı 1994,107(Pt 8):2219-28.

110 van Russen F, de Jongh GJ, van Erp PE, Boezeman JB, Schalkwıjk J. Cell kuneric characterizacion of culcured human keracunocyres from normal and psoriatic individuals. J Cell Physıol 1996;168(3):684-94.

111 Van Ruissen F, de Jongh GJ, Zeeuwen PL, Van Erp PE, Madsen P, Schalkwık J Induction of normal and psoriauc phenotypes in submerged keratinocyte cultures.

J Cell Physiol 1996,168(2):442-52.

112. Pfundr $R, W$ ingens $M$, Bergers $M, Z$ weers $M$, Frenken $M$, Schalkwık J. TNF-alpha and serum induce SKALP/elafin gene expression in human keratinocytes by a p38 MAP kunase-dependent pathway

Arch Dermatol Res 2000,292(4), 180-7.

113 Wingens $M$, van Bergen BH, Hiemstra PS, Meis JF, van Vlımen-Willems IM, Zeeuwen PL, et al Induction of SLPI (ALP/HUSI-I) in epidermal keratınocytes. J Invest Dermatol 1998;111(6)·996-1002

114. Swart GW, van Groningen JJ, van Ruissen F, Bergers M, Schalkwık J Transcription facror C/EBPalpha. novel sires of expression and cloning of the human gene Biol Chem 1997;378(5) 373-9.
115. van Russen F, Le M, Carroll JM, van der Valk PG, Schalkwijk J. Differential effeets of detergents on keratinocyte gene expression.

J Invest Dermatol 1998;110(4):358-63

116. Fuchs $E$. Beauty is skun deep: the fascinating biology of the eptdermıs and its appendages. Harvey Lect 1998,94:47-77.

117. Watt FM, Hogan BL Out of Eden' stem cells and their niches.

Science 2000;287(5457):1427-30.

118. Bagutt C, Wobus AM, Fassler R, Watt FM. Differentuation of embryonal stem cells into keratinocytes comparson of wild-type and beta 1 integrin-deficient cells.

Dev Biol 1996;179(1)·184-96.

119. Baguttı C, Hutter C, Chıquet-Ehrısmann R, Fassler R, Watt FM. Dermal fibroblast-derived growth factors restore the abilicy of beta(1) integrin-deficient embryonal stem cells to differentiate into keratinocytes.

Dev Bıol 2001;231(2):321-33.

120 Eckert RL, Crish JF, Banks EB, Welter JF The epidermus. genes on - genes off. J Invest Dermatol 1997,109(4) 501-9

12I. Eckert RL, Crish JF, Robinson NA. The epidermal keratinocyte as a model for the study of gene regulation and cell differentiation Physiol Rev 1997,77(2) 397-424

122 Pankov R, Umezawa A, Maku R, Der CJ, Hauser CA, Oshıma RG. Oncogene activation of human keratın 18 transeription via the Ras sıgnal transduction pathway Proc Narl Acad Scı U S A 1994;91(3):873-7.

123. Cheng $C$, Tennenbaum T, Dempsey PJ, Coffey RJ, Yuspa SH, Dlugosz AA. Epidermal growth factor receptor ligands regulate keratin 8 expression in keratinocytes, and transforming growth factor alpha mediates the induction of keratun 8 by the $v$-rasHa oncogene. Cell Growth Differ 1993;4(4):317-27

124 Pankov R, Neznanov N, Umezawa A, Oshıma RG AP-1, ETS, and transcriptional slencers regulate retınoic acid- dependent induction of keratin 18 in embryonic cells. Mol Cell Bıol 1994,14(12)·7744-57

125 Chambon P. A decade of molecular biology of retinoic acid receptors FASEB J 1996; 10(9):940-54 
126 Xrao JH, Durand B, Chambon P, Voorhees JJ

Endogenous retınoic acid receptor

(RAR)-retinoid X receptor (RXR) heterodimers are the major functional forms regulating retınoid- responsive elements in adult human keratınocytes. Binding of ligands to RAR only is sufficient for RAR-RXR heterodimers to confer ligand- dependent activation of hRAR beta 2/RARE (DR5).

J Bıol Chem 1995;270(7) 3001-11

127. Elder JT, Fisher GJ, Zhang QY, Eısen D, Krust A, Kastner P, et al. Retinoic acid receptor gene expression in human skan J Invest Dermatol 1991;96(4).425-33.

128. L M, Indra AK, Warot $X$, Brocard J, Messaddeq N, Kato S, et al. Skun abnormalities generated by temporally controlled RXRalpha mucations in mouse epidermis Nature 2000;407(6804):633-6.

129. L M, Chiba H, Warot X, Messaddeq N, Gerard C, Chambon P, et al. RXR-alpha ablation in skun keratinocytes results in alopecia and epidermal alterations. Development 2001;128(5):675-88

130. Kastner P, Grondona JM, Mark M, Gansmuller A, LeMeur M, Decimo D, et al Genetic analysis of RXR alpha developmental function convergence of RXR and RAR signalıng pathways in heart and cye morphogenesis. Cell 1994,78(6):987-1003

131 Subbarayan V, Kastner P, Mark M, Dierich A, Gorry P, Chambon P. Limited specificiry and large overlap of the functions of the mouse RAR gamma 1 and RAR gamma 2 isoforms. Mech Dev 1997;66(1-2):131-42.

132. Imalado S, Bıckenbach JR, Bundman DS, Rothnagel JA, Attar PS, Wang XJ, et al. Targerıng expression of a domınant-negative retinoic acid receptor mutant in the epidermıs of transgenic mice results in loss of barrier function. Genes Dev 1995;9(3):317-29.

133 Feng X, Peng ZH, Di W, L XY, Rocherre-Egly C, Chambon P, et al. Suprabasal expression of a dominant-negative RXR alpha mutant in transgenic mouse epidermis impars regulation of gene transcription and basal keratinocyte proliferatıon by RAR-selective retınoids. Genes Dev 1997,11(1):59-71.
134 Kochhar DM, Jang $H$, Penner JD, Johnson AT, Chandraratna RA. The use of a retinoid receptor antagonist in a new model to study vitamın A-dependent developmental events. Int J Dev Bıol 1998;42(4):601-8

135 Li YC, Pirro AE, Amlıng M, Dellıng G, Baron R, Bronson R, et al Targeted ablation of the vitamin $D$ receptor an animal model of vitamin D-dependent rickets type II with alopecia Proc Natl Acad Sa U S A 1997;94(18):9831-5.

136 Satoh A, Hansen LA, Vogel JC, Udey MC. Characterizauon of Wht gene expression in murıne skin. possible involvement of epidermis-derived Wnt-4 in curaneous epithelıa- mesenchymal interactions.

Exp Cell Ros 1998;243(1):150-60

137. Kishimoto J, Burgeson RE, Morgan BA. Wnr signaling maintans the hair-inducing activity of the dermal papilla.

Genes Dev 2000;14(10):1181-5

138. Fuchs E, Merrill BJ, Jamora C, DasGupta R At the Roots of a Never-Ending Cycle. Dev Cell 2001;1(1)-13-25

139. Huelsken J, Vogel R, Erdmann B, Cotsarelıs G, Birchmeier W. beta-Catemin controls hair follucle morphogenesis and stem cell differentiation in the skun Cell 2001,105(4):533-45.

140. Thelu J, Viallet JP, Dhouarlly D Differential expression partern of the three Fringe genes is associated with epidermal differentiation.

J Invert Dermarol 1998;111(5):903-6.

141. Lowell S, Jones P, Le Roux I, Dunne J, Watt FM. Stumulation of human epidermal differentiation by delta-notch signalling at the boundaries of stem-cell clusters. Curr Brol 2000;10(9):49]-500.

142. Rangarajan A, Talora C, Okuyama $R$, Nicolas M. Mammucari C, Oh $\mathrm{H}$, er al Norch signaling is a direct dererminant of keratinocyte growth arrest and entry into differentiation. EMBO J 2001;20(13).3427-36.

143. Lowell S, Watt FM Delea regulates keratınocyte spreading and motility undependently of differentiauon. Mech Dev 2001,107(1-2):133-40.

144. Cano E, Mahadevan LC. Parallel signal processing among mammalian MAPKs Trends Bıochem Scı 1995;20(3):117-22. 
145 Smeyne RJ, Vendrell M, Hayward M, Baker SJ, Miao GG, Schuling K, et al Contınuous c-fos expression precedes programmed cell death in vivo Nature 1993;363(6425): 166-9.

146 Basset-Seguin N, Escot C, Blanchard JM, Kerai C, Verrier B, Mion $\mathrm{H}$, et al High levels of $c$-fos proto-oncogene expression in normal human adult skun

J Invest Dermatol 1990:94(4):418-22.

147 Ohtsuks M, Flanagan S, Freedberg IM, Blumenberg $M$. A cluster of five nuclear proteıns regulates keratin gene transcription. Gene Expr 1993,3(2) 201-13

148 Leask A, Byrne C, Fuchs E. Transcription factor AP2 and iss role in epidermal-specific gene expression. Proc Natl Acad Sci U S A $1991 ; 88(18): 7948-52$.

149 Magnaldo T, Bernerd F, Freedberg IM. Ohtsuku M, Blumenberg M. Transcriptional regulators of expression of $K \# 16$, the disease- associated keratın. DNA Cell Bıol 1993;12(10) 911-23.

150. LaPres JJ, Hudson LG. Idenufication of a functional determinant of differentiationdependent expression in the involucrin gene J Biol Chem 1996;271(38) 23154-60

151 Marıniello L, Qın Q, Jessen BA, Rice RH. Keratınocyte transglutaminase promoter analysis. Identification of a functional response element. J Biol Chem 1995,270(52)·31358-63

152. Fischer DF, Gibbs S, van De Putte P, Backendorf C. Interdependent transcription control elements regulate the expression of the SPRR2A gene during keratınocyte termınal differentiation Mol Cell Biol 1996;16(10) 5365-74.

153. Lee JH, Jang SI, Yang JM, Markova NG, Steinert PM. The proxımal promoter of the human transglutaminase 3 gene Stratified squanous epithelial-specific expression in cultured cells is mediated by binding of Spl and ets transcription factors to a proxamal promoter element.

J Biol Chem 1996;271(8):4561-8.

154 Faus I, Hsu HJ, Fuchs E. Oct-6 a regulator of keratınocyte gene expression in stratıfied squamous epthelia.

Mol Cell Biol 1994;14(5):3263-75

155 Welter JF, Galı H, Crısh JF, Eckert RL. Regulation of human involucrin promoter actuvity by POU doman proteıns.

J Bıl Chem 1996;271(25)·14727-33.
156. Zhou J, Finch PW. Identification of a novel transcriptional regulatory element within the promoter region of the keratunocyte growth factor gene that mediates inducibulity to cyclic AMP

Bıochım Bıophys Acta 1999;1446(1-2) 71-81.

157. Sesz CS, Lin Q, Deng H, Khavari PA

Alterations in NF-kappaB function in transgenic epithelial tissue demonstrate a growth inhibitory role for NF-kappaB. Proc Natl Acad Scı U S A 1998;95(5) $\cdot 2307-12$

158. Seız CS, Deng H, Hınata K, Lin Q, Khavarı PA. Nuclear factor kappaB subunits induce epithelial cell growth arrest.

Cancer Res 2000;60(15):4085-92.

159. Qin JZ, Chaturvedı V, Denning MF, Choubey D, Diaz MO, Nickoloff BJ Role of NF-kappaB in the apoptouc-resistant phenorype of keratınocytes. J Biol Chem 1999;274(53):37957-64

160 Wu H, Moulton K, Horva A, Parik S, Glass CK Combinatorial interactions between $\mathrm{AP}-1$ and ets doman proteins contribuce to the developmental regulation of the macrophage scavenger recepror gene. Mol Cell Bıol 1994;14(3):2129-39.

161 Tornic-Canıc M, Komine M, Freedberg IM, Blumenberg M. Epıdermal signal transduction and transcription factor activation in actuvated keratınocytes. J Dermatol Sci 1998;17(3).167-81.

162. Geulen CC, Wieprecht M, Orfanos CE The mitogen-activated protein kinases system (MAP kunase cascade) • tts role in skun sıgnal transduction. A review J Dermatol Sci 1996,12(3) 255-62.

163. Dlugosz AA, Yuspa SH Protein kunase C regulates keratınocyte transglutamınase (TGK) gene expression in culured primary mouse epidermal keratinocytes induced to terminally differenciace by calcium. J Invest Dermatol 1994;102(4)·409-14

164. Rosenthal DS, Steinert PM, Chung S, Huff CA, Johnson J, Yuspa SH, et al. A human epidermal differentiation-specific keratın gene is regulated by calcium but not negative modulators of differentiation in transgenic mouse keratinocyies. Cell Growth Differ 1991,2(2)·107-13. 
165. Voorhees JJ. “Psoriasis as a possible defect of the adenyl cyclase-cyclic AMP Cascade" by Voorhees and Duell, Ocrober 1971.

Commentary' Cyclic adenosine monophosphate regulation of normal and psoriatic epıdermis Arch Dermatol 1982;118(10)·862-74

166 Voorhees JJ, Duell EA. Psoriasis as a possible defect of the adenyl cyclase-cyclic AMP cascade. A defective chalone mechanusm' Arch Dermatol 1971,104(4).352-8.

167 Nsshizuka $Y$. The role of protein kinase $C$ in cell surface signal transduction and cumour promotion Narure 1984;308(5961) ·693-8

168 Srreb H, Irvine RF, Berrıdge MJ, Schulz I. Release of $\mathrm{Ca} 2+$ from a nonmitochondrial intracellular store in pancreatic acinar cells by inosicol-1,4,5-trisphosphate. Nature 1983;306(5938)-67-9.

169. Detmar M, Gelen CC, Wieder T, Orfanos CE, Reutter W. Phospholipid analogue hexadecylphosphocholine inhibits proliferation and phospharidylcholine biosynthesis of human epidermal kerannocyres in vitro. J Invest Dermatol 1994;102(4):490-4

170 Ullnich A, Schlessinger J. Signal transduction by receptors with tyrosine kunase activity. Cell 1990;61(2):203-12.

171. Koch CA, Anderson D, Moran MF, Ellıs C, Pawson $\mathrm{T}$ SH2 and $\mathrm{SH} 3$ domans elements that control interactions of cytoplasmic signaling proteins Science 1991;252(5006)·668-74

172. Leigh IM, Navsarı H, Purkus PE, McKay IA, Bowden PE, Riddle PN. Keratins (K16 and K17) as markers of keratınocyte hyperproliferation in psoriasis in vivo and in vitro Br J Dermatol 1995;133(4):501-11.

173. Komine M, Rao LS, Freedberg IM, Simon M, Milisavjevic V, Blumenberg $M$. Interleuknn-1 induces transcription of keratin $\mathrm{K} 6$ in human epidermal keratinocyes J Invest Dermatol 2001;116(2):330-8

174. Komıne M, Rao LS, Kaneko T, Tomic-Canıc M, Tamaki K, Freedberg IM, et al Inflammarory versus proliferative processes in epıdermis. Tumor necrosis factor alpha induces K6b keratın synthesis through a transcriptional complex contaning NFkappa B and C/EBPbeta. J Bıol Chem 2000,275(41).32077-88.
175. Paladini RD, Takahashı K, Bravo NS, Coulombe PA. Onset of re-epthelialization after skin injury correlates with a reorganization of keratın filaments in wound edge keratinocytes. definıng a porentıal role for keratın 16 J Cell Biol 1996;132(3) 381-97.

176. Nemes Z, Stemert PM Bricks and mortar of the epidermal barrier.

Exp Mol Med 1999:31(1)-5-19.

177. Harder J, Bartels J, Christophers E, Sehroder JM. A peptide antibiotic from human skin. Narure 1997:387(6636):861.

178. Tezula T, Takahashi M, Katsunuma N. Cystatin alpha ts one of the component proteins of keratohyalın granules. J Dermatol 1992;19(11)·756-60

179. Takahashı M, Tezuka T, Katunuma N. Phosphorylated cystatin alpha is a natural substrate of epidermal transglutaminase for formation of skın cornified envelope FEBS Lett 1992;308(1) 79-82

180 Takahashı M, Tezuka T, Katunuma N. Inhibition of growch and cysteine proteinase activity of Staphylococcus aureus V8 by phosphorylated cystatın alpha in skan cornufied envelope. FEBS Lett 1994;355(3).275-8.

181 Takahash $M$, Tezuka T, Kakegawa $H$, Katunuma N. Lunkage berween phosphorylared cystarın alpha and filaggrin by epidermal transgluraminase as a model of cornufied envelope and inhibition of cathepsin $L$ activity by cornufied envelope and the conjugated cystatin alpha. FEBS Lett 1994;340(3)-173-6

182. Schalkwijk J, de Roo C, de Jongh GJ. Skun-derived antuleukoprotennase (SKALP), an elastase inhibitor from human keratınocytes. Purification and biochemical properties Bıchım Bıophys Acta 1991;1096(2) 148-54.

183 Molhuizen HO, Schalkwijk J. Structural, biochemical, and cell biological aspects of the serıne proreinase inhıbitor SKALP/elafin/ESI. Bıol Chem Hoppe Seyler 1995;376(1):1-7.

184 Pfundt $R$, van Ruissen $F$, van Vlımen-Willems $I M$, Alkemade HA, Zeeuwen PL, Jap PH, et al. Constıtutive and inducible expression of SKALP/elafin provides antI- elastase defense in human epithelia J Clin Invest 1996;98(6) 1389-99. 
185 Molhuizen HO, Alkemade HA, Zeeuwen PL, de Jongh GJ, Wierınga B, Schalliwık J

SKALP/elafin: an clastase inhıbitor from culrured human keratınocytes. Purıfication, cDNA sequence, and evidence for transglutaminase cross- linking

J Biol Chem 1993;268(16):12028-32.

186. Barker JN, Mitra RS, Griffiths CE, Dixit VM, Nickoloff BJ. Keratınocytes as initiators of inflammation Lancet 1991;337(8735).211-4.

187. Granger GA, Shacks SJ, Willıans TW, Kolb WP Lymphocyte in vitro cytotoxıcity: specific release of lymphotoxin-like materials from tuberculın-sensitıve lymphoid cells. Nature 1969;221(5186) 1155-7

188 Carswell EA, Old LJ, Kassel RL, Green S, Fiore N, Willıamson B. An endotoxın-ınduced serum facror that causes necrosis of tumors. Proc Natl Acad Scı U S A 1975;72(9):3666-70.

189. Pennica D, Nedwin GE, Hayflıck JS, Seeburg PH, Derynck R, Palladino MA, et al Human tumour necrosis factor. precursor structure, expression and homology to lymphotoxın Nature 1984;312(5996)·724-9.

190 Gray PW, Aggarwal BB, Benton CV, Bnngman TS, Henzel WJ, Jarrett JA, et al Cloning and expression of cDNA for human lymphotoxan, a lymphokane with tumour necrosis activity. Nature 1984;312(5996):721-4.

191. Wallach D, Varfolomeev EE, Malınin NL Goltsev YV, Kovalenko AV, Boldın MP.

Tumor necrosis factor receptor and Fas signalıng mechanisms.

Annu Rev Immunol 1999;17:331-67.

192. Ashkenazi A, Dixit VM. Dearh receptors. signalıng and modulation Science 1998;281(5381):1305-8.

193. Locksley RM, Kılleen N, Lenardo M] The TNF and TNF receptor superfamilies: integratıng mammalıan bıology. Cell 2001;104(4) 487-501

194. Baud V, Karın M. Signal transduction by tumor necrosis factor and its relatives.

Trends Cell Bıol 2001;11(9)·372-7

195 Schulze-Osthoff K, Ferran D, Los M, Wesselborg S Perer ME. Apoptosis signalıng by death receprors. Eur J Brochem 1998;254(3):439-59.

196 Hsu H, Xıong J, Goeddel DV. The TNF receptor 1 -associated protein TRADD signals cell death and NF- kappa B activation Cell 1995;81(4):495-504
197 Hsu H, Shu HB, Pan MG, Goeddel DV TRADD-TRAF2 and TRADD-FADD Interactions define two distınct TNF receptor 1 signal transduction pachways. Cell 1996;84(2) 299-308.

198. Kischkel FC, Lawrence DA, Chuntharapa A, Schow P, Kim KJ, Ashkenaz1 A Apo2UTRAILdependent recrustment of endogenous FADD and caspase-8 to death receprors 4 and 5 . Immunity 2000;12(6):611-20.

199. Kuang AA, Diehl GE, Zhang J, Winoto A. FADD is required for DR4- and DR5-mediared apoptosis. lack of trarl- induced apoprosis in FADD-deficient mouse embryonic fibroblasts. J Biol Chem 2000,275(33):25065-8.

200 Schneider P, Thome M, Burns K, Bodmer JL, Hofmann K, Kataoka T, et al. TRAIL receptors 1 (DR4) and 2 (DR5) signal FADD-dependent apoptosis and activate NF-kappaB Immunıty 1997;7(6):831-6

201. Fernandes-Alnemrı T, Armstrong RC, Krebs J, Srınivasula SM, Wang L, Bullrich F, et al In vitro activation of CPP32 and Mch3 by Mch4, a novel human apoptoric cysreıne prorease containing two FADD-lıke domains. Proc Nat Acad Sci U S A 1996;93(15) 7464-9

202. Vincenz C, Dixit VM. Fas-associated death doman protein interleutun-I beta-converting enzyme 2 (FLICE2), an ICE/Ced-3 homologue, is proximally involved in CD95- and p55-mediated death sıgnaling J Bıol Chem 1997,272(10):6578-83

203. Boldın MP, Goncharov TM, Golrsev YV, Wallach D. Involvement of MACH, a novel MORT1/FADD-1nteracting protease, in Fas/APO-1 - and TNF receptor-induced cell death. Cell 1996;85(6)·803-15

204. Muzio M, Chunnayan AM, Kischkel FC, O'Rourke K, Shevchenko $A, N_{1}$ J, er al FLICE, a novel FADD-homologous ICE/CED-3-lıke protease, is recruted to the CD95 (Fas/APO-1) death--inducing signalıng complex Cell 1996;85(6):817-27

205 Krammer PH. CD95's deadly mission in the Immune system Nature 2000;407(6805) 789-95.

206 Muzo M, Stockwell BR, Stennıcke HR, Salvesen GS, Dixit VM. An induced proximity model for caspase-8 activation. J Biol Chem 1998,273(5):2926-30 
207. Salvesen GS, Duxat VM. Caspase activation: the induced-proxumity model Proc Natl Acad ScI U S A 1999;96(20):10964-7.

208 Nicholson DW. From bench to clinic with apoptosis-based therapeutic agents Narure 2000;407(6805):810-6.

209 Nicholson DW, Thornberry NA.

Caspases: kuller proteases.

Trends Blochem Sci 1997;22(8)·299-306.

210. Gross A, Yin XM, Wang K, Weı MC, Jockel J, Millıman $C$, et al. Caspase cleaved BID targets mitochondria and is required for cytochrome $c$ release, while $\mathrm{BCL}-\mathrm{XL}$ prevents this release but not tumor necrosis factor-R1/Fas death J Bıol Chem 1999;274(2):1 156-63.

211 Korsmeyer SJ, Gross A, Harada H, Zha J, Wang $K, Y_{i n} X M$, et al. Death and survival signals derermine active/ınactive conformations of pro-apoprotic BAX, BAD, and BID molecules Cold Spring Hart Symp Quant Biol 1999;64:343-50.

212. Wei MC, Lindsten T, Mootha VK, Weiler $S$, Gross A, Ashiya $M$, et al tBID, a membranerargeted dearh ligand, oligomerizes BAK to release cytochrome c.

Genes Dev 2000; 14(16):2060-71

213 Zhou P, Chou J, Olea RS, Yuan J, Wagner G. Solution structure of Apaf-1 CARD and its interaction with caspase-9 CARD. a structural basis for specific adaptor/caspase interaction Proc Natl Acad Sa U S A 1999,96(20).11265-70.

214. Fesik SW Insights into programmed cell death through structural biology.

Cell 2000; 103(2):273-82.

215. Humke EW, Shriver SK, Starovasnk MA, Farbrother WJ, Dixit VM ICEBERG. a novel inhibitor of interleukun-l beta generation. Cell 2000;103(1):99-111.

216. Slee EA, Adran C, Martin SJ. Executtoner caspase-3, -6 , and -7 perform distınct, non-redundant roles during the demoliuon phase of apoptosis. J Bıol Chem 2001;276(10)·7320-6

217 Levkau B, Koyama H, Ranes EW, Clurman BE, Herren B, Orth K, et al Cleavage of p21Cipl/Wafl and p27Kıpl medıates apoptosis in endothelial cells through activation of Cdk2: role of a caspase cascade. Mol Cell 1998;1(4)·553-63
218 Buendia B, Santa-Maria A, Courvalin JC. Caspase-dependent proteolysis of integral and peripheral proteins of nuclear membranes and nuclear pore complex proreins during apoprosis. J Cell Sc1 1999,112(Pr |1):1743-53.

219 Enarı M, Sakahira H, Yokoyama H, Okawa K, Iwamatsu A, Nagata S. A caspase-activated DNase that degrades DNA during apoptosis, and its inhibitor ICAD Nature 1998;391(6662).43-50.

220. Sakahira $H$, Enarı $M$, Nagata $S$ Cleavage of CAD inhibitor in CAD activation and DNA degradacion during apoptosis. Nature 1998,391(6662) 96-9.

221. Liu X, Li P, Widlak P, Zou H, Luo X, Garrard WT, et al The $40-\mathrm{kDa}$ subunit of DNA fragmentation factor induces DNA fragmentation and chromatun condensation during apoptosis. Proc Natl Acad Seı U S A 1998;95(15):8461-6

222 Liu X, Zou H, Slaughter C, Wang X. DFF, a heterodimeric protein that functions downstream of caspase-3 to trigger DNA fragmentation during apoptosis.

Cell 1997;89(2):175-84

223. Wyllie AH, Kerr JF, Currie AR Cell death: the significance of apoptosis Int Rev Cyrol 1980;68:251-306

224. Weiss $T$, Grell M, Siemienski K, Muhlenbeck $F$, Durkop $H$, Pfizenmayer $K$, et al. TNFR80dependent enhancement of TNFR60-induced cell death is mediated by TNFR-associated factor 2 and is specific for TNFR60. J Immunol 1998;161(6) 3136-42

225. Peschon JJ, Torrance DS, Stockung KL, Glaccum MB, Otten C, Willis CR, et al. TNF receptor-deficient mice reveal divergent roles for p55 and p75 in several models of inflammation. J Immunol 1998,160(2):943-52.

226 Douni E, Kollias G A critical role of the p75 tumor necrosis factor receptor (p75TNF-R) in organ inflammation independent of TNF lymphotoxin alpha, or the P5STNF-R. J Exp Med 1998; 188(7) 1 1343-52

227 Wiley SR, Schooley K, Smolak PJ, Din WS, Huang CP, Nicholl JK, et al. Idencification and characterization of a new member of the TNF family that induces apoptosis Immuntty 1995;3(6) 673-82 
228. Pan G, Ni J, We1 YF, Yu G, Gentz R, Diut VM. An antagonist decoy receptor and a death doman-contanıng receptor for TRAIL Science 1997,277(5327):815-8.

229. Pan G, O'Rourke K, Chinnayan AM, Gentz R, Ebner R, Ni J, et al. The recepror for the cytotoxuc ligand TRAIL. Science 1997;276(5309):111-3.

230. Walcak H, Degli-Esposti MA, Johnson RS, Smolak PJ, Waugh JY, Boianı N, et al. TRAIL-R2: a novel apoptosis-mediating receptor for TRAIL. EMBO J 1997;16(17).5386-97.

231. Sheridan JP, Marsters SA, Pitti RM, Gurney A, Skubatch M, Baldwin D, et al. Control of TRAIL-ınduced apoptosis by a farnily of sıgnalıng and decoy receptors.

Science 1997;277(5327):818-21

232 Degli-Espost1 MA, Smolak PJ, Walcak H, Waugh J, Huang CP, DuBose RF, et al Cloning and characterization of TRAIL-R3, a novel member of the emerging TRALL receptor family. J Exp Med 1997;186(7):1 165-70.

233 Deglu-Esposti MA, Dougall WC, Smolak PJ, Waugh JY, Smıth CA, Goodwin RG The novel receptor TRAIL-R4 induces NF-kappaB and protects agaunst TRAIL-mediated apoptosis, yet retains an incomplete death doman Immunity 1997,7(6):813-20.

234. Schuevella AR, Chen JH, Graham JR, Lin LL. MADD, a novel death domann protein that interacts with the rype I rumor necrosis factor receptor and activates mitogen-actuvated protein kınase. J Biol Chem 1997,272(18) 12069-75

235. Reinhard C, Shamoon B, Shyarnala V, Willams LT Tumor necrosis factor alpha-induced acrivation of c-jun $\mathrm{N}$-terminal kunase is mediated by TRAF2, EMBO J 1997.16(5):1080-92.

236 Wajant $\mathrm{H}$, Henkler $F$, Scheurich $P$.

The TNF-receptor-associated factor famly. scaffold molecules for cytokane receptors, kunases and their regulators.

Cell Signal 2001,13(6) 389-400.

237 Kelliher MA, Grımm S, Ishida Y, Kuo F, Stanger $\mathrm{BZ}$, Leder $\mathrm{P}$. The dearh domain kınase RIP mediates the TNF-Induced NF-kappaB signal Immunity 1998;8(3):297-303.

238 Thome M, Hofmann K, Burns K, Martinon F, Bodmer JL, Mattmann C, et al Identification of CARDLAK, a RIP-like kunase that associates with caspase-1 Curr Biol 1998;8(15) 885-8
239. Yu PW, Huang BC, Shen M, Quast J, Chan E, Xu X, et al. Identification of RIP3, a RIP-like kınase that acuvates apoptosıs and NFkappaB. Curr Biol 1999;9(10)·539-42

240 Duan H, Duut VM. RAIDD is a new 'death' adaptor molecule. Nature 1997;385(6611)·86-9.

241 Ahmad M, Srinivasula SM, Wang L, Talanian RV, Lirwack G. Fernandes-Alnemrı $T$, et a. CRADD, a novel human apoptotic adaptor molecule for caspase-2, and FasL/rumor necrosis factor receptor-interacting protein RIP Cancer Res 1997,57(4):615-9.

242. Lee FS, Hagler J, Chen ZJ, Manatis $T$. Activation of the IkappaB alpha kınase complex by MEKK1, a kunase of the JNK pathway. Cell 1997;88(2).213-22

243. Malının NL, Boldın MP, Kovalenko AV, Wallach D. MAP3K-related kunase involved in NF-kappaB induction by TNF, CD95 and IL-1. Nature 1997;385(6616)·540-4.

244. Ling L, Cao Z, Goeddel DV. NF-kappaBinducing kınase activates IKK-alpha by phosphorylarion of Ser- 176. Proc Natl Acad Sa U S A 1998;95(7) ·3792-7

245. Nakano H, Shındo M, Sakon S, Nishınaka S, Mihara M, Yagita $H$, et al. Differential regulation of IkappaB kunase alpha and beta by two upstream kinases, NF-kappaB-ınducıng kınase and mitogen-actuvated protein kunase/ERK kunase lunase-1. Proc Natl Acad Seı U S A 1998;95(7):3537-42.

246 Regnier CH, Song HY, Gao X, Goeddel DV, Cao Z, Rothe M. Identufication and characterization of an IkappaB kunase. Cell 1997;90(2)·373-83.

247. DiDonato JA, Hayakawa $M$, Rothwarf DM, Zandı E, Karın M A cytokune-responsıve IkappaB kunase that activates the transcription factor NF-kappaB. Nature 1997;388(6642):548-54.

248. Mercurio F, Zhu H, Murray BW, Shevehenko A, Bennett BL, LI J, et al IKK-I and IKK-2: cytokune-activated IkappaB kunases essential for NF- kappaB activation. Science 1997,278(5339) $860-6$

249. Zand $E$, Rothwarf DM, Delhase $M$, Hayakawa $M$, Karin M The IkappaB kunase complex (IKK) contans two kanase subunits, IKKalpha and IKKbeta, necessary for IkappaB phosphorylation and NF-kappaB actrvation. Cell 1997,91(2) 243-52 
250. Woronicz JD, Gao X, Cao Z, Rothe M, Goeddel DV. IkappaB kunase-beta- NF-kappaB activation and complex formation with IkappaB kunase-alpha and NIK Science 1997;278(5339):866-9.

251 Saccanı S, Pantano S, Natolı G. Two waves of nuclear factor kappaB recrument to arget promoters. J Exp Med 2001;193(12):1351-9.

252. Zhuang L, Wang B, Shinder GA, Shivi GM, Mak TW, Sauder DN. TNF receptor 555 plays a pivotal role in murine keratınocyte apoptosis induced by ultraviolet $B$ urradiation.

J Immunol 1999;162(3) $1440-7$

253 Kondo S, Sauder DN. Tumor necrosis factor (TNF) receptor type 1 ( $\mathrm{p} 55$ ) is a main mediator for TNF-alpha-induced skun inflammation Eur J Immunol 1997;27(7):1713-8.

254. Moore RJ, Owens DM, Stamp G, Arnot C. Burke F, East N, et al. Mice deficient in tumor necrosis factor-alpha are resistant to skin Carcinogenesis. Nac Med 1999;5(7):828-31.

255 Wang B, Fujisawa $H$, Zhuang L, Kondo S, Shivji GM, Kım CS, et al. Depressed Langerhans cell migrarion and reduced contact hypersensitivity response in mice lackung TNF receptor p75. J Immunol 1997;159(12):6148-55

256. Klement JF, Ruce NR, Car BD, Abbondanzo S], Powers GD. Bhatt PH, et al. IkappaBalpha deficiency resules in a sustaned NF-kappaB response and severe widespread dermatitus in mice. Mol Cell Bıol 1996;16(5):2341-9.

257. Li Q, Lu Q. Hwang JY, Buscher D, Lee KF, Izpisua-Belmonte JC, et al. IKK1-deficient mice exhibit abnormal development of skin and keleton Genes Dev 1999;13(10):1322-8.

258. L, Q, Estepa G, Memet S, Israel A, Verma IM. Complete lack of NF-kappaB activity in IKKI and IKK2 double-deficient mice: additional defect in neurulation. Genes Dev 2000;14(14):1729-33.

259. Makris C, Godfrey VL, Krahn-Senfuleben G, Takahashi T, Robers JL, Schwarz T, et al. Female mice heterozygous for IKK gamma/NEMO deficiencies develop a dermatopathy sımilar to the human X-linked disorder incontinentıa pigmentu. Mol Cell 2000;5(6):969-79.

260 Schmidt-Supprian M, Bloch W, Courtors G, Addıcks K, Israel A, Rajewsky K, et al. NEMO/IKK gamma-deficient mice model incontinentia pigmentı Mol Cell 2000;5(6):981-92
261 Headon DJ, Overbeek PA. Involvement of a novel Tnf receptor homologue in harr follicle Induction. Nat Genet 1999;22(4) 370-4.

262 Monreal AW, Ferguson BM, Headon DJ, Street SL, Overbeek PA, Zonana J. Mutations in the human homologue of mouse $\mathrm{dl}$ cause autosomal recessive and dominant hypohidrotıc ectodermal dysplasia Nat Genet 1999;22(4):366-9.

263 Botchkareva NV, Botchkarev VA, Chen LH, Lindner G, Paus R. A role for p75 neurotrophen receptor in the control of har follicle morphogenesis Dev Bıol 1999,216(1):135-53.

264. Peschon JJ, Slack JL, Reddy P, Stockung KL, Sunnarborg SW, Lee DC, et al. An essentual role for ectodomarn sheddıng in mammalian development. Science 1998,282(5392).1281-4

265. Aderem A, Ulevitch RJ. Toll-like receptors in the induction of the innate ummune response Nature 2000;406(6797) $782-7$

266. Ortonne JP. Recent developments in the understanding of the pachogenesis of psoriasis. Br J Dermatol 1999;140 Suppl 54:1-7

267. Nickoloff BJ Skin innate immune system in psoriasis: friend or foe? J Clin Invest 1999;104(9):1161-4.

268. Craven NM, Jackson CW, Kurby B, Perrey C. Pravica V, Hutchinson IV, et al. Cytokune gene polymorphusms in psonasis. Br J Dermatol 2001,144(4):849-53.

269. Mrowien. U Advances in systemic therapy for psoriasıs. Clın Exp Dermatol 2001;26(4):362-7

270. Oh CJ, Das KM, Gotrlieb AB Treatment with antı-tumor necrosis factor alpha (TNF-alpha) monoclonal antibody dramatically decreases the clinical activity of psoriasis lesions J Am Acad Dermatol 2000;42(5 Pt 1):829-30.

271. Chaudharı U, Romano P, Mulahy LD, Dooley LT, Baker DG, Gortlieb AB. Efficacy and safery of influximab monotherapy for plaque-type psoriasis. a randomised trial. Lancer 2001;357(9271):1842-7.

272. Mease PJ, Goffe BS, Mez J, VanderStoep A, Finck B, Burge DJ. Etanercept in the treatment of psorıatic arthritıs and psorıasıs: a randomised trial. Lancet 2000;356(9227) $385-90$

273 Moreland LW, Schuff MH, Baumgarner SW, Tindall EA, Fleischmann RM, Bulpitt KJ, et al Etanercept therapy in rheumatoid arthritss. A randomized, controlled trial Ann Intern Med 1999;130(6).478-86 


\section{, \\ Serial Analysis of Gene Expression
in differentiated cultures of human \\ Serial Analysis of Gene Expression
in differentiated cultures of human \\ epidermal keratinocytes (1)}
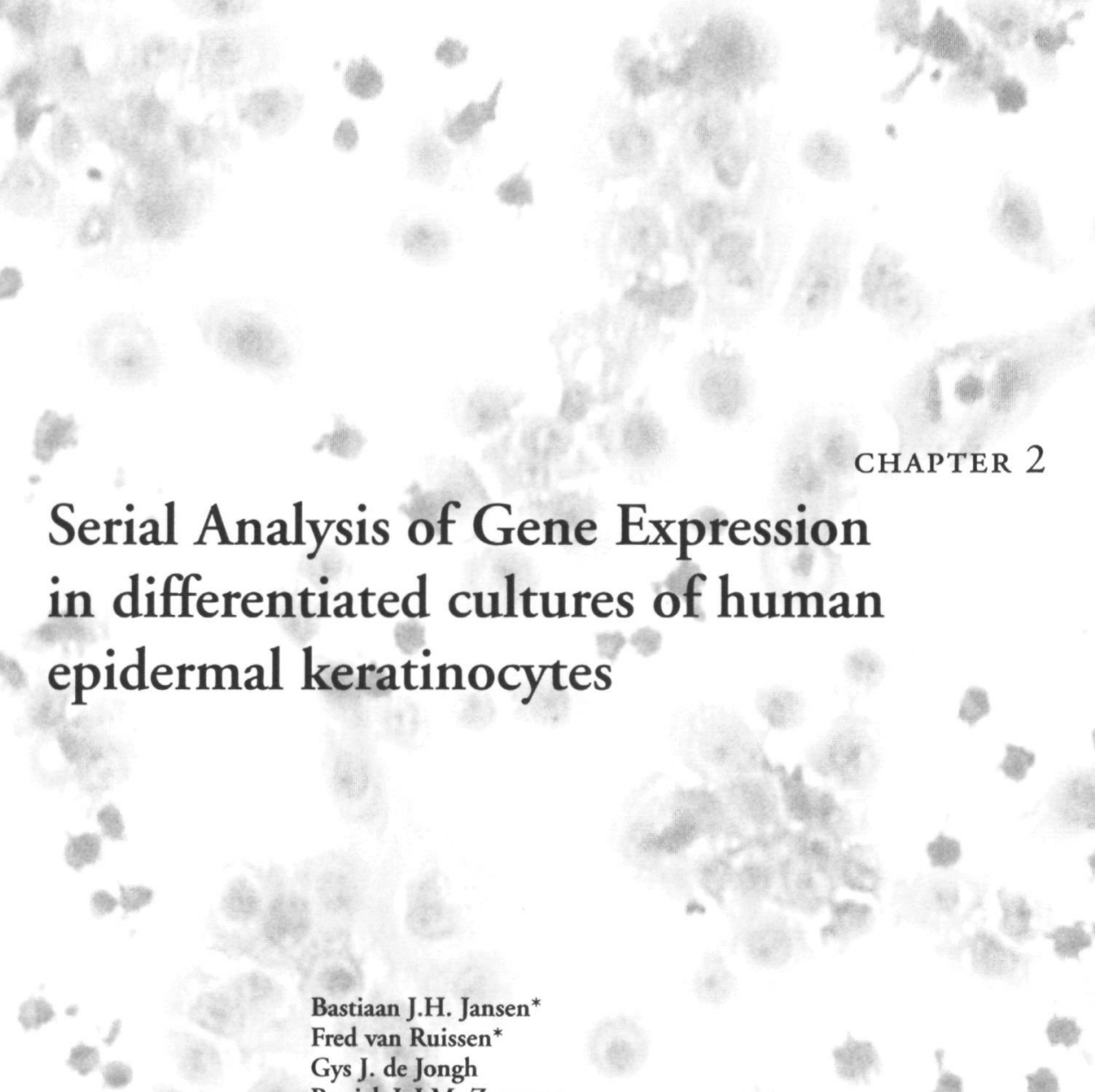

Bastiaan J.H. Jansen*

Fred van Ruissen*

Gys J. de Jongh

Patrick L.J.M. Zeeuwen

Joost Schalkwijk

Department of Dermatology

University Medical Center St. Radboud

PO Box 9101

6500 HB Nijmegen

The Netherlands

*These authors contributed equally to this Chapter

This Chapter has been published as:

Jansen B.J.H., Van Ruissen F., De Jongh G., Zeeuwen P.L.J.M., Schalkwijk J.

Serial Analysis of Gene Expression in differentiated cultures

of human epidermal keratinocytes. J.Invest Dermatol. 2001;116(1):12-22. 

Keratinocyte gene expression was surveyed more comprehensively than before, by means of Serial Analysis of Gene Expression. A total of 25,694 tags derived from expressed mRNA were analyzed in a model for normal differentiation and in a model where cultured keratinocytes were stimulated for a prolonged period of time with tumor necrosis factor- $\alpha$, thus mimicking aberrant differentiation in the context of cutaneous inflammation. Serial analysis of gene expression revealed many transcripts derived from unknown genes and a large number of genes that are nor known to be expressed in keratinocytes; furthermore, these data provide quantitative information about the relative abundance of transcripts, allowing the identification of differentially expressed genes. A major part of the identified transcripts accounted for genes involved in energy metabolism and protein synthesis. A large proportion of all transcripts (6\%) corresponded to genes associated with terminal differentiation and barrier formation. Another highly expressed functional group of genes ( $2 \%$ of all transcripts) corresponded to proteins involved in host protection such as antimicrobial proteins and proteinase inhibitors. Three of these genes were not known to be expressed in keratinocytes, and some were upregulated after prolonged tumor necrosis factor- $\alpha$ exposure. Our data on expressed genes in keratinocytes are consistent with the known function of human epidermis, and provide a first step to generate a transcriptome of human keratinocytes. 
The keratinocyte is the major cell type in mammalian epidermis, which provides the organism with a protective barrier against pathogens and chemical or physical stimuli. A complex program of gene expression underlies the tightly coordinated differentiation of keratinocytes, and eventually leads to the unique structure of the epidermis i-s. Proliferating, undifferentiated cells in the basal layer supply the upper layers with new cells, which enter a state of terminal differentiation. Ultimately, these cells die and form the outermost cornified layer or stratum corneum in which the dead, flattened cells or corneocytes form a covalently cross-linked protein network embedded in lipids. In addition to the formation of the cornified layer that provides a physical barrier, keratinocytes are also engaged in innate and adaptive immunity. This is illustrated by the ability of keratinocytes to present antigens ${ }^{4}$, to express various proteins involved in host protection ${ }^{5.8}$, and to secrete cytokines and chemokines ${ }^{9}$. Furthermore, keratinocytes have cytokine receptors and adhesion molecules on their plasma membranes through which they interact with inflammatory cells, and they can be regulated in both an autocrine and paracrine fashion ${ }^{10}$. Both the innate immune response and the interaction with the immune system during wound healing, skin infections, and inflammation, show that keratinocytes serve as an important signaling interface berween the external environment and the organism.

There is considerable knowledge about gene expression profiles in human keratinocytes in vivo and in culture, especially on genes encoding cytoskeletal and structural proteins ${ }^{11-13}$. On the protein level Celis et al. ${ }^{14}$ have extensively analyzed gene expression in epidermis and cultured keratinocytes, using two-dimensional polyacrylamide gel electrophoresis (2D-PAGE) and microsequencing (see http://biobase.dk/cgi-bin/celis/). Recently, a partial catalog of secreted proteins in keratinocyte cultures was published by Katz \& Taichman ${ }^{15}$. No systematic studies on keratinocyte gene expression at the mRNA level have been undertaken so far, although a considerable amount of data is available from randomly sequenced keratinocyte cDNA libraries ${ }^{16}$, differential display polymerase chain reaction (PCR) ${ }^{172}$ and cDNA filter arrays ${ }^{23}$.

In order to perform a systematic, comprehensive study of keratinocyte gene expression at the mRNA level, we used serial analysis of gene expression (SAGE) ${ }^{24}$. SAGE allows the rapid, quantitative, and simultaneous analysis of thousands of genetic transcripts from a well-defined source, and also provides information about their relative abundance. SAGE is based on two principles: first, a nucleotide sequence of 10 bps is sufficient to identify uniquely a transcript and second, by cloning these 10 bp fragments or 'tags' serially, along with a restriction enzyme recognition sequence that serves as an anchor, a large amount of transcripts can be identified efficiently through sequencing. To achieve this, mRNA is first isolated and converted to cDNA with biotinylated oligo-dT, and cDNA is then digested with the restriction endonuclease NlaIII at the recognition sequence CATG. This recognition sequence occurs randomly every $256 \mathrm{bps}$, and serves as the anchor. The most $3^{\prime}$ end fragments of cDNA are isolated with streptavidin-coated magnetic beads, then divided into two portions and ligated to two distinct linkers. This is followed by digestion with a 'tagging' endonuclease to release the linker with a tag of approximately $10 \mathrm{bps}$. The two portions are then combined to ligate, and the resulting 'ditag' is being amplified with linkerspecific primers. Ditags are then liberated from linkers by $N$ LaIII digestion, followed by ligation of the ditags to form concatemers. These concatemers are cloned into a suitable sequencing vector, allowing serial sequencing of ditags (see FIGURE 1 for SAGE overview). 


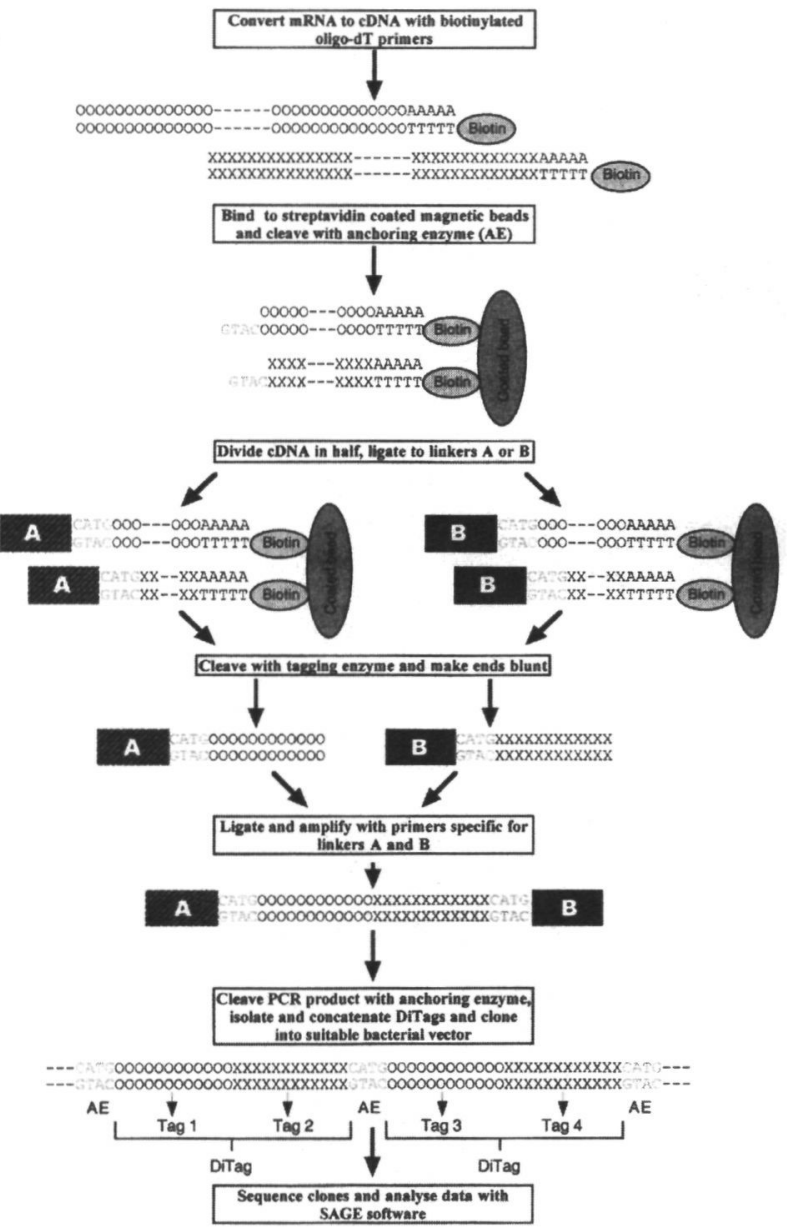

FIGURE 1 Schematic overview of the SAGE technique. A dashed line represents any possible DNA sequence, and $\mathrm{X}$ and $\mathrm{O}$ represent any of the four possible deoxynucleotides $\mathrm{A}, \mathrm{C}, \mathrm{G}$, or $\mathrm{T}$. For explanation see introduction.

We have applied SAGE to analyze gene expression profiles in a keratinocyte culture model that we have previously described ${ }^{5,25}$. This model allows the development of a differentiated phenotype in a submerged culture system, as witnessed by the expression of involucrin, transglutaminase, and cytokeratins CK1 and CK10. As it is known that keratinocyte gene expression is altered under inflammatory conditions (such as psoriasis or wound healing) that last for a relatively long period of time, we investigated the indirect effect of tumor necrosis factor- $\alpha$ (TNF- $\alpha$ ) on cultured keratinocytes as a model for inflammationinduced, long-term changes in epidermis. Normally, TNF- $\alpha$ exerts a direct effect on its tar- 
get cell in a matter of hours. Ligation to one of its receptors, TNF receptor I or II, can either lead to apoptosis within hours through a caspase-dependent pathway, or induce a stress response through various pathways leading to the activation of nuclear factor kappa $\beta$ $(\mathrm{NF}-\mathrm{kB})$ and, subsequently, to the transcription of various genes ${ }^{26-28}$. Stimulation of cultured keratinocytes with TNF- $\alpha$ and other cytokines, however, also sets off a cascade of events that can trigger secondary effects, leading to long-term, aberrant differentiation as seen in inflammatory conditions of the skin. To investigate the changes in keratinocyte gene expression due to these secondary effects, two SAGE libraries from resting keratinocytes and keratinocytes after long-term stimulation with TNF- $\alpha$ were constructed, and subjected to further analysis as described in this study.

\section{Materials and methods}

\section{Cells and cell culture}

Primary human epidermal keratinocytes were obtained as previously described ${ }^{25}$. Cells (16 $\times 10^{6}$ ) were grown to confluency in $75 \mathrm{~cm}^{2}$ culture flasks under keratinocyte growth medium (KGM), consisting of KBM $\left(0.15 \mathrm{mM} \mathrm{Ca}{ }^{2 \cdot}\right.$ BioWhittaker, Verviers, Belgium) supplemented with ethanolamine $(0.1 \mathrm{mM}$; Sigma, St Louis, MO), phosphoethanolamine ( $0.1 \mathrm{mM}$, Sigma), bovine pituitary extract $(0.4 \% \mathrm{vol} / \mathrm{vol}$; BioWhittaker, Verviers, Belgium) epidermal growth factor (10 $\mathrm{ng} / \mathrm{ml}$; Sigma), insulin $(5 \mu \mathrm{g} / \mathrm{ml}$; Sigma), hydrocortisone (0.5 $\mu \mathrm{g} / \mathrm{ml}$; Collaborative Research, Lexington, MA), penicillin (100 U/ml; Life Technologies, Gaithersburg, MD), and streptomycin ( $100 \mu \mathrm{g} / \mathrm{ml}$; Life Technologies). Cells were switched to KGM depleted of growth factors (bovine pituitary extract, epidermal growth factor, hydrocortisone, and insulin) for 48 hrs before half of the cells ( $8 \times 10^{6}$ cells) was swirched ro KGM depleted of growth factors for an additional 48 hrs to induce normal differentiation, whereas the other half was switched to KGM depleted of growth factors containing 25 $\mathrm{ng} / \mathrm{ml}$ TNF- $\alpha$ (R\&D Systems, Minneapolis, MN). Non-adherent cells were washed off with phosphate buffered saline, and RNA was isolated as indicated below.

\section{RNA isolation}

Total RNA was isolated from normal and stimulated keratinocytes by lysing cells in RNase All (2.1 M guanidine thiocyanate (Research Organics, Cleveland, $\mathrm{OH}$ ), $8.5 \mathrm{mM} N$-laurylsarcosine (Sigma), $12.5 \mathrm{mM} \mathrm{NaAc} \mathrm{pH} 5.2,0.35 \%$ v/v $\beta$-mercaptoethanol (Merck GmbH, Darmstadr, Germany) and 50\% v/v Tris-saturated phenol pH 8.0 (Biosolve, Amsterdam, the Netherlands)), and total RNA was extracted by adding $1 / 10$ of a volume of chloroform and centrifugation at $12,000 \mathrm{xg}$ at $4^{\circ} \mathrm{C}$ for $15 \mathrm{~min}$. The aqueous phase was recovered and total RNA was precipitated by adding an equal volume of isopropanol, followed by an incubation on ice for $45 \mathrm{~min}$. RNA was pelleted by centrifugation at 12,000 $\mathrm{xg}$ for $15 \mathrm{~min}$, and the pellet was washed with $70 \%$ ethanol and dried at room temperature. The pellet was then resuspended in $3.6 \mathrm{ml} \mathrm{NSE}(50 \mathrm{mM} \mathrm{NaAc}, 0.2 \%$ sodium dodecyl sulfate, $2 \mathrm{mM}$ ethylenediamine tetraacetic acid) and $13.5 \mathrm{ml} \mathrm{100 \%}$ ethanol was added. For quantitation, $100 \mu$ of this suspension was used to pellet RNA, and the pellet was resuspended in $1 \mathrm{ml} \mathrm{H} \mathrm{H}_{2} \mathrm{O}$. Purity and concentration of total RNA were determined spectrophotometrically. Subsequently, mRNA was isolated using the QuickPrep Micro mRNA Purification Kit (Pharmacia Biotech, Uppsala, Sweden), according to the manufacturer's protocol. 
Purıfied mRNA was used to generate SAGE librarıes from both normal and stımulated keratınocytes, essentially as described previously ${ }^{24}$ The SAGE protocol and the SAGE Software Package version 304 were kindly provided by Dr. K Kunzler (Johns Hopkuns Oncology Center, Baltımore, MD) Isolated concatemers, consıstıng of serially ligated tags, were ligated into pUC18 (Invitrogen, San Diego, CA) and transformed in chemically competent MAX Efficiency DH5 $\alpha$ Escherichra coll Competent Cells (Life Technologies) by means of heat-shock transformation, following the manufacturer's protocol Colony PCR ${ }^{21}$ was performed on positive colonies with $\mathrm{PUCl}^{\mathrm{U}}$-specific primers $\mathrm{pUC18-F}$ (5'AAGTTGGGTAACGCCAGG-3') and pUC18-R (5'-GGCTCGTATGTTGTGTGG$\left.3^{\prime}\right)$ and PCR products were analyzed by agarose gel electrophoresis. 1,800 clones were selected for DNA sequencing with the Big Dye Termınator Kit and the $-21 \mathrm{M} 13$ sequencing primer (PE Applied Biosystems, Foster City, CA), according to the manufacturer's recommendations Sequencing reactions were run on an ABI 310 Genetic Analyzer Sequence data were analyzed with the SAGE Software Package v3 04, and online with the SAGE analysis tools at the website of the National Center for Biotechnology Information (NCBI), Bethesda, MD (http //www.ncbı nlm nih gov/SAGE/).

\section{Reverse transcription-PCR}

Total RNA from which the SAGE libraries were derived, was used for reverse transcription with Expand Reverse Transcriptase (Boehringer Mannheım, Mannheım, Germany) according to the manufacturer's protocol, followed by PCR following standard protocols " Primers used for amplification of the corresponding gene transcripts were for radiationinducible immediate-early response gene 1 (IEX-1) - 5'-TGTCACTCTCGCAGCTGC-3 and 5'-CTCTTCAGCCATCAGGATCTG-3', cyrokeratın 1 (CK1) 5'-CT'TGCTCTGGTACAAGGACTCGGC-3' and 5'-TTCCTTACAGCACTCTACCA-3' and migration inhibitory factor-related protein 8 (MRP-8) 5'-CGGGATCCATGTTGACCGAGCTGG-3' and 5-CGGAATTCCTACTCTTTGTGGCTTTCT-3' Copy DNAs were cloned into the pGEM-T vector, according to the manufacturer's recommendations (Promega, Madıson, WI) Purified plasmids were sequenced in order to verify inserts

\section{Northern blot hybridization}

Northern blot analysis was essentially carried out as described previously, and most cDNA clones have been described elsewhere ${ }^{25}$ The cDNA for cystatin $M$ was cloned as described previously ${ }^{30}$ Labelling with $\left[\alpha-{ }^{32} \mathrm{P}\right]$ deoxycytidine triphosphate was carried out with the Oligolabelıng Kut (Pharmacia Biotech) according to the manufacturer's directions 


\section{Results}

\section{General results and statistics}

Cells were cultured under conditions that allow differentiation in a submerged system as previously described 5. ${ }^{25}$. Messenger RNA was purified from TNF- $\alpha$ stimulated keratinocytes and from an equivalent number of normally differentiated cells, and analyzed using SAGE. A total number of 25,694 tags was generated, roughly half of which were from TNF- $\alpha$ stimulated cells and the other half from normal cells. A large number of tags corresponding to genes known to be highly expressed in epidermis were identified, as well as many genes not previously known to be expressed by keratinocytes. The expression of several genes of these two categories was verified by Northern blot hybridization. In all cases examined, the expression of genes represented by tags in either SAGE library was confirmed. A third category of transcripts represents tags with matches to poorly characterized expressed sequence tags (ESTs), or with no match in the public mRNA databases. Approximately 6,000 different tags were expressed in each library, putatively corresponding to an equal number of genes. Both libraries have a similar frequency distribution. About $78 \%$ of unique genes are represented by only one tag, whereas slightly more than $1 \%$ of unique genes identified in each library were represented by more than 20 tags; this is independent of culture conditions (TABLE 1). The combined data set for the two libraries

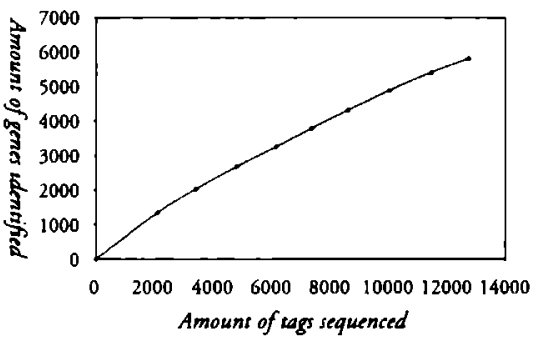

FIGURE 2 The number of unique genes plotted against the number of tags sequenced from the combined libraries. The number of unique genes identified is roughly proportional to the number of sequenced tags. Sequence tags were generated and analyzed using the SAGE Software Package v3.04.

indicates that a total of 10,224 likely genes has been identified. FIGURE 2 shows that the number of genes identified is nearly proportional to the amount of tags sequenced, and extrapolation of the curve suggests that the theoretical number of unique tags will be well over 12,000. Clearly, far more tags need to be sequenced to obtain a complete and reliable coverage of expressed genes (a 'transcriptome') in these cells, as was previously performed for Saccharomyces cerevisiae ${ }^{31}$. In TABLE 2, 20 tags that are expressed at the highest levels in our keratinocyte SAGE libraries, regardless of stimulation, are shown, as well as their corresponding UniGene cluster. A list of tags found in both libraries will be made available to the public at our Website (http://dermatology.azn.nl/) in the near furure. Statistical analysis with the SAGE Software Package (v3.04) revealed that 90 genes show a significant difference $(p<0.05)$ in expression level. Forty-seven genes were upregulated and 43 downregulated after TNF- $\alpha$ stimulation. Of these 90 genes, 15 genes appeared to have no match in UniGene, six matched solely with EST clusters, and 69 matched with clusters of known genes in the UniGene database (UniGene Build \#108; see also http://www.ncbi.nlm.nih.gov/SAGE/ and http://www.ncbi.nlm.gov/UniGene/), whereas some tags had multiple matches with otherwise unrelated genes (TABLE 3). These data do not necessarily reflect the biologic relevance of differential expression, as small differences between high scoring tags obviously lead to high p-values. For instance, galectin-7 shows only a minor (less than 2 -fold) decrease following TNF- $\alpha$ stimulation, but this difference is statistically highly significant due the high expression levels of this gene (about $2 \%$ of the total). 
Libraries

Frequency distribution ${ }^{*} \quad$ TNF- $\alpha$ stımulated

\begin{tabular}{lr} 
& \multicolumn{2}{c}{ Genes } \\
$\geq 20$ tags $^{* *}$ & $72(12 \%) * * *$ \\
$5-19$ tags & $271(45 \%)$ \\
$2-4$ tags & $1,018(169 \%)$ \\
I tag & $4,653(774 \%)$
\end{tabular}

Tags

$3,472(27 \%)$

$2,331(18 \%)$

$2,509(19 \%)$

$4,653(36 \%)$

$\begin{array}{rc}\text { Genes } & \text { Tags } \\ 80(14 \%) & 3,820(30 \%) \\ 228(39 \%) & 2,039(16 \%) \\ 928(160 \%) & 2,292(18 \%) \\ 4,578(787 \%) & 4,578(36 \%)\end{array}$

* Calculation of the frequency distribucion of a given tag was based on a total number of 12,965 sequenced tags from TNF- $\alpha$ sumulated keratınocytes, and 12,729 tags from restıng keraunocytes A total of 6,014 unique genes was identified in the library of stimulated cells, and a total of 5,814 genes was identıfied in the library of resting cells

** Tags per unique gene

*** Percentage of unıque genes in frequency group

\section{Ihe awenty ags with highest expression in the wo combined SACil libraries}

\begin{tabular}{|c|c|c|c|}
\hline Tag Sequence & $\begin{array}{l}\text { Total no. } \\
\text { of tags* }\end{array}$ & $\begin{array}{l}\text { UniGene } \\
\text { cluster** }\end{array}$ & Cluster name \\
\hline TAAACCTGCT & 518 & Hs 99923 & lecun, galactoside-bındıng, soluble, 7 (galectın 7) \\
\hline GATGTGCACG & 406 & Hs 117729 & $\begin{array}{l}\text { keraun } 14 \text { (epidermolysıs bullosa sımplex, } \\
\text { Dowlıng-Meara, Koebner) }\end{array}$ \\
\hline CTTCCTTGCC & 352 & Hs 2785 & keranın 17 \\
\hline TGTGTTGAGA & 286 & $\begin{array}{l}\text { Hs } 181165 \\
\text { Hs } 251674\end{array}$ & $\begin{array}{l}\text { eukaryotic translation elongation factor } 1 \text { alpha } 1 \\
\text { eukaryotic translation elongation factor } 1 \text { alpha } 1 \text {-like } 14\end{array}$ \\
\hline CCCAAGCTAG & 204 & Hs 76067 & heat shock $27 \mathrm{kD}$ protein 1 \\
\hline CCCTTGAGGA & 191 & $\begin{array}{l}\text { Hs } 1076 \\
\text { Hs } 46320\end{array}$ & $\begin{array}{l}\text { small prolıne-rıch proteın 1B (cornıfin) } \\
\text { small prolıne-rıch protein SPRK } \\
\text { [human, odontogenic keratocysts, mRNA Partıal, } 317 \mathrm{nt} \text { ] }\end{array}$ \\
\hline GTGACCACGG & 188 & $\begin{array}{l}\text { Hs } 36451 \\
\text { Hs } 244733\end{array}$ & $\begin{array}{l}\text { glutamate receptor, ionotropic, } \mathrm{N} \text {-methyl D aspartate } 2 \mathrm{C} \\
\text { ESTs, highly similar to GLUTAMATF (H sapiens) }\end{array}$ \\
\hline CTAAGACTTC & 164 & - & No match \\
\hline GAAAACAAAG & 163 & Hs 99936 & $\begin{array}{l}\text { keratın } 10 \text { (epidermolytıc hyperkeratosıs, } \\
\text { keratosıs palmarıs et plantarıs) }\end{array}$ \\
\hline AAAGCACAAG & 162 & Hs 111758 & keratın 6B \\
\hline CCCGTCCGGA & 126 & Hs 180842 & ribosomal protein L13 \\
\hline TTGGGGTTTC & 122 & Hs 62954 & ferritun, heavy polypeptide 1 \\
\hline TTGGTCCTCT & 119 & Hs 108124 & ribosomal protein 141 \\
\hline ACATTTCAAA & 118 & Hs 80828 & keratın 1 (epidermolyuc hyperkeratosıs) \\
\hline GCCGTGTCCG & 114 & Hs 241507 & ribosomal protein $\$ 6$ \\
\hline CCACAGGAGA & 109 & Hs 23579 & ESTs \\
\hline ATCCГTGCTG & 104 & Hs 2621 & cystaun A (stefin A) \\
\hline CCTGTAATCC & 104 & Multıple clusters & Clusters matching multuple, unrelated genes \\
\hline GTGGCCACGG & 102 & Hs 112405 & S100 calcıum-bındıng proteın A9 (calgranulın B) \\
\hline TGGTGTTGAG & 100 & $\mathrm{Hs}_{5} 75362$ & ribosomal protein $\$ 18$ \\
\hline
\end{tabular}

* Total number of tags from the combined data set of the two SAGE libraries, containing a total of 25,694 tags

** Derived from UniGene Build \#108, known genes are from GenBank 114 (December 1, 1999),

ESTs are from dbEST through February 13, 2000 


\begin{tabular}{|c|c|c|c|c|c|}
\hline \multirow[b]{2}{*}{ Tag sequence } & \multicolumn{3}{|c|}{ Number of tags per library* } & \multirow[b]{2}{*}{$\begin{array}{l}\text { UniGene } \\
\text { cluster }^{* * *}\end{array}$} & \multirow[b]{2}{*}{ Cluster name } \\
\hline & TNF- $\alpha$ & Resting & P-value ${ }^{* *}$ & & \\
\hline TAAACCTGCT & 194 & $324^{* * * *}$ & 0.0000 & Hs. 99923 & $\begin{array}{l}\text { lectun, galactoside-binding, } \\
\text { soluble, } 7 \text { (galectın } 7 \text { ) }\end{array}$ \\
\hline GTGACCACGG & 148 & 40 & 0.0000 & $\begin{array}{l}\text { Hs. } 36451 \\
\text { Hs } 244733\end{array}$ & $\begin{array}{l}\text { glutamate receptor, ınotropıc, N-methyl D- } \\
\text { aspartate } 2 \mathrm{C} \\
\text { ESTs, highly sımilar to GLUTAMATE } \\
\text { [H.sapıens] }\end{array}$ \\
\hline GTAATCCTGC & 30 & 3 & 0.0000 & - & No match \\
\hline TGGTGTTGAG & 29 & 71 & 0.0000 & Hs.75362 & ribosomal protein 518 \\
\hline AGAGGTGTAG & 17 & 0 & 0.0000 & Hs. 135084 & $\begin{array}{l}\text { cystatin C (amyloid angiopathy and } \\
\text { cerebral hemorrhage) }\end{array}$ \\
\hline GCCGTGTCCG & 37 & 77 & 0.0001 & Hs.241507 & ribosomal protein 56 \\
\hline TTCATACACC & 7 & 29 & 0.0001 & - & No match \\
\hline TTGGTGAAGG & 35 & 10 & 0.0002 & Hs.75968 & thymosin, beta $4, X$ chromosome \\
\hline GCAACTTAGA & 16 & 1 & 0.0002 & Hs. 54451 & $\begin{array}{l}\text { lamınin, gamma } 2 \text { (niceın (100kD), } \\
\text { kalının (105kD), BM600 (100kD), } \\
\text { Herliz junctional epıdermolysıs bullosa)) }\end{array}$ \\
\hline CAAGCATCCC & 12 & 36 & 0.0003 & - & No match \\
\hline AAAGCACAAG & 104 & 58 & 00003 & Hs. 111758 & keratin 6B \\
\hline GTGGCCACGG & 69 & 33 & 0.0003 & Hs 112405 & $\begin{array}{l}\text { S100 calcıum-bındıng proteın A9 } \\
\text { (calgranulin B) }\end{array}$ \\
\hline CTCAACATCГ & 26 & 55 & 00006 & Hs.73742 & ribosomal protem, large, P0 \\
\hline CCCATCGTCC & 29 & 59 & 00007 & - & No match \\
\hline TACCTGCAGA & 34 & 12 & 0.0011 & Hs. 100000 & $\begin{array}{l}\text { S100 calcıum-bindıng protein A8 } \\
\text { (calgranulin A) }\end{array}$ \\
\hline CCGTCCAAGG & 8 & 26 & 0.0013 & Hs 80617 & ribosomal protein S16 \\
\hline CCCCCTGGAT & 14 & 35 & 00016 & Hs 183418 & cell division cycle 2-lkke 1 (PTTSLRE proteins) \\
\hline CTAAGACTTC & 64 & 100 & 00019 & - & No match \\
\hline CCAGGGGAGA & 9 & 0 & 00021 & Hs 2867 & interferon, alpha-ınducible protein 27 \\
\hline CGCGTCACTA & 9 & 0 & 00021 & Hs 135084 & $\begin{array}{l}\text { cystatın C (amyloid angiopathy } \\
\text { and cerebral hemorrhage) }\end{array}$ \\
\hline CTTCCCITGC & 2 & 13 & 00032 & - & No match \\
\hline GACGACACGA & 9 & 25 & 00038 & Hs. 153177 & ribosomal protein $\mathrm{S} 28$ \\
\hline
\end{tabular}

table consinued on nas page

* SAGE library of TNF- $\alpha$ stimulated keratinocytes contans a total of 12,965 tags, whereas the library of restung keratınocytes contains 12,729 tags.

** All significant differences in expression levels wirh p-values less than 005 are sorred according to significance level Tags were analysed using the SAGE. Software Package 3.04, and p-values were derermined by performing Monte Carlo simulatıons, given the null hypothesis that the level, kind and distribution of tags is the same for both libraries

*** Derıved from UnıGene Build \#108; known genes are from GenBank 114 (December 1, 1999), ESTs are from dbEST through February 13, 2000.

**** Bold numbers indicate upregulation in respective library 
Number of tags per library*

Tag sequence

$\begin{array}{lllll}\text { CCCITGAGGA } & 78 & 113 & 0.0043 & \text { Hs.1076 }\end{array}$

Hs. 46320

$\begin{array}{lllll}\text { GAAAACAAAG } & 65 & 98 & 0.0043 & \text { Hs.99936 } \\ \text { GCTCCCAGAC } & \mathbf{8} & 0 & 00045 & \text { Hs.5097 } \\ \text { CCAGTGGCCC } & 10 & 26 & 00048 & \text { Hs.180920 } \\ \text { AAAAAAAAAA } & 5 & 18 & 0.0048 & \text { Muluple clusters } \\ \text { GCAACAACAC } & \mathbf{2 0} & 6 & 00049 & \text { Hs } 186571 \\ \text { CTCATAAGGA } & \mathbf{2 8} & 11 & 0.0058 & - \\ \text { TTGGGGTTTC } & 76 & 46 & 00058 & \text { Hs } 62954 \\ \text { CCCGTCCGGA } & 49 & 77 & 0.0060 & \text { Hs } 180842 \\ \text { TGATTTCACT } & 6 & 19 & 00065 & \text { Hs } 181368 \\ \text { GCCTGCTGGG } & 24 & 9 & 0.0078 & \text { Hs.2706 } \\ & & & & \\ \text { CGCTGGTTCC } & 9 & 23 & 0.0085 & \text { Hs.179943 } \\ \text { GTGGTACAGG } & \mathbf{4} & 15 & 0.0086 & \text { Hs } 23131 \\ & & & & \text { Hs.31731 }\end{array}$

$\begin{array}{lllll}\text { ATCTTGTTAC } & 7 & 0 & 0.0086 & \text { Hs } 118162 \\ \text { ATCCTTGCTG } & 40 & 64 & 0.0089 & \text { Hs.2621 } \\ \text { CCTGTAATCC } & 40 & 64 & 0.0089 & \text { Multuple clusters } \\ \text { CGTGTTAATG } & 9 & 1 & 0.0107 & \text { Hs.2110 } \\ & & & & \\ \text { GAGATCCGCA } & 9 & 1 & 0.0107 & \text { Hs.247710 }\end{array}$

Hs.75348

$\begin{array}{lllll}\text { CTGTCACCCT } & 33 & 54 & 0.0134 & \text { Hs.46320 }\end{array}$

$\begin{array}{lllll}\text { GAGGAGGGTG } & \mathbf{2 7} & 12 & 00145 & \text { Hs.75318 } \\ \text { AAGAAGACTT } & 6 & 0 & 0.0145 & \text { Hs.7719 } \\ \text { CCACTGCATT } & 6 & 0 & 00145 & \text { Hs } 199245 \\ \text { CCCICAGCAC } & 6 & 0 & 0.0145 & \text { Hs.87268 } \\ \text { CTCATAAGGG } & 6 & 0 & 00145 & \text { Hs } 29835 \\ & & & & \\ \text { GGTTGAGTGT } & \mathbf{6} & 0 & 00145 & \text { Hs 20529 } \\ \text { CTGTTGGTGA } & 15 & \mathbf{3 0} & 0.0149 & \text { Hs.3463 } \\ \text { TAAGCCTGCT } & 0 & \mathbf{6} & 00150 & - \\ \text { TGGTGTTAAG } & 0 & \mathbf{6} & \mathbf{0 . 0 1 5 0} & \text { Hs } 75362\end{array}$

\section{Cluster name}

small prolıne-rich protein $1 B$ (cornıfin)

small proline-rich protein SPRK

[human, odontogenic keratocysts, mRNA Partual, $317 \mathrm{nt}$ ]

keratın 10 (epidermolycic hyperkeratosıs; keratosis palmarıs et plantaris)

synaptogyrin 2

ribosomal protern $S 9$

Clusters matching multiple, unrelated genes

TRF-proximal protein

No match

ferriun, heavy polypepude 1

ribosomal protenn $\mathrm{L} 13$

myosın-bındıng proteın $\mathrm{C}$, cardıac

glutathione peroxidase 4

(phospholıpid hydroperoxidase)

ribosomal procein L11

kınesin family member $\mathrm{C} 3$

ESTs, highly sımılar to PUTATIVE

PEROXISOMAL ANTIOXIDANT

ENZYME [H.sapiens]

fibronectun 1

cystatun A (stefin A)

Clusters matching multıple genes

zinc finger protein 9 (a cellular retroviral nucleic acid binding protein)

Homo sapiens mRNA for preproprolactin-releasing peptide, complete cds proteasome (prosomc, macropan) activator subunit 1 (PA28 alpha) Small proline-rich protein SPRK (human, odontogenic keratocysts, mRNA Partıal, $317 \mathrm{nt}$ ] rubulin, alpha 1 (testıs specific) GABA(A) receptor-associated protein inactivation escape 1 annexin $A 8$ wingless-type MMTV integration site family, member $2 B$

ESTs ribosomal protein S23

No match ribosomal proteın $\mathrm{S} 18$ 


\begin{tabular}{|c|c|c|c|c|c|}
\hline \multirow[b]{2}{*}{ Tag sequence } & \multicolumn{3}{|c|}{ Number of tags per library* } & \multirow[b]{2}{*}{$\begin{array}{l}\text { UniGene } \\
\text { cluster*** }\end{array}$} & \multirow[b]{2}{*}{ Cluster name } \\
\hline & TNF- $\alpha$ & Resting & p-value ${ }^{* *}$ & & \\
\hline AGCCCTACAA & 6 & 17 & 0.0164 & - & No match \\
\hline AGCAGATCAG & 31 & 15 & 0.0165 & Hs. 119301 & $\begin{array}{l}\text { S100 calcıum-bındıng protein A10 } \\
\text { (annexin II ligand, calpactın I, } \\
\text { light polypeptıde (pl l)) }\end{array}$ \\
\hline CTTCTTGCCT & 14 & 4 & 0.0165 & Hs. 128095 & $\begin{array}{l}\text { ESTs, moderarely similar to } \\
\text { GLUTAMATE RECEPTOR, } \\
\text { IONOTROPIC KAINATE } 5\end{array}$ \\
\hline & & & & Hs.75792 & $\begin{array}{l}\text { PRECURSOR [H.sapiens] } \\
\text { hemoglobın, alpha l }\end{array}$ \\
\hline GATGTGCACG & 227 & 179 & 0.0178 & Hs.117729 & $\begin{array}{l}\text { keratın } 14 \text { (epıdermolysıs bullosa simplex, } \\
\text { Dowlıng-Meara, Koebner) }\end{array}$ \\
\hline GCCCGTGTCC & 1 & 8 & 0.0178 & Hs.241507 & ribosomal protein $\$ 6$ \\
\hline ACGCAGGGAG & 23 & 10 & 0.0200 & Hs. 180532 & heat shock $90 \mathrm{kD}$ protein 1 , alpha \\
\hline CCCATCCGAA & 29 & 47 & 0.0213 & Hs. 91379 & ribosomal protenn L26 \\
\hline ATCGTGGAGG & 10 & 2 & 0.0223 & Hs.727 & $\begin{array}{l}\text { Inhibın, beta } A \text { (actıvin } A \text {, } \\
\text { activin } A B \text { alpha polypeptide) }\end{array}$ \\
\hline GGTGAGACAC & 8 & 1 & 0.0227 & Hs. 164280 & adenine nucleotıde translocator 3 (liver) \\
\hline TAAAATGTAT & 8 & 1 & 00227 & Hs.161566 & ESTs \\
\hline & & & & Hs. 194104 & $\begin{array}{l}\text { ESTs, weakly similar to intrinsıc factor-B } 12 \\
\text { receptor precursor [H.sapıens] }\end{array}$ \\
\hline GGCAAGAAGA & 13 & 26 & 0.0235 & Hs.111611 & ribosomal protein L27 \\
\hline CCTCGGAAAA & 6 & 16 & 00249 & Hs.2017 & ribosomal proteın $\mathrm{L} 38$ \\
\hline TGTGCTAAAT & 9 & 20 & 0.0249 & Hs. 250895 & ribosomal protein L34 \\
\hline AGGGCTTCCA & 26 & 13 & 0.0289 & Hs. 29797 & ribosomal proteın L10 \\
\hline TTTGTAGAGG & 16 & 6 & 0.0304 & Hs. 32426 & ESTs \\
\hline CCССTTGAGG & 1 & 7 & 0.0305 & - & No match \\
\hline AAGGGCGCGG & 0 & 5 & 0.0316 & Hs. 1378 & annexin $A 3$ \\
\hline ACAGTGATGA & 0 & 5 & 0.0316 & - & No match \\
\hline ACCGCCTGTG & 0 & 5 & 0.0316 & Hs.240443 & $\begin{array}{l}\text { ESTs, weakly simılar to HNK-1 } \\
\text { sulforransferase [H sapiens] }\end{array}$ \\
\hline ATGTAAAATC & 0 & 5 & 0.0316 & Hs 111758 & keratın 6B \\
\hline CTCATCTGCT & 0 & 5 & 0.0316 & $\mathrm{Hs} .82109$ & syndecan 1 \\
\hline GATGCGCACG & 0 & 5 & 0.0316 & - & No match \\
\hline GTGTAATAAG & 0 & 5 & 0.0316 & Hs.75598 & $\begin{array}{l}\text { heterogeneous nuclear ribonucleoproteın } \\
\mathrm{A} 2 / \mathrm{BI}\end{array}$ \\
\hline AACGAGGAAT & 5 & 0 & 0.0332 & - & No match \\
\hline AAGAGTTTTG & 5 & 0 & 00332 & $\mathrm{Hs} 75313$ & $\begin{array}{l}\text { aldo-keto reductase family } 1 \text {, } \\
\text { member } \mathbf{B l} \text { (aldose reductase) }\end{array}$ \\
\hline AAGCTGTGTC & 5 & 0 & 00332 & Hs 108332 & $\begin{array}{l}\text { ubıquirin-conjugating enzyme E2D } 2 \\
\text { (homologous to yeast UBC } 4 / 5 \text { ) }\end{array}$ \\
\hline AATGCTTTGT & 5 & 0 & 00332 & Hs. 248323 & tubulın, alpha, brain-specific \\
\hline ССТТСССАТА & 5 & 0 & 00332 & - & No match \\
\hline CGCTGTGGGG & 5 & 0 & 00332 & Hs 7486 & protein expressed in thyroid \\
\hline
\end{tabular}




\begin{tabular}{|c|c|c|c|c|c|}
\hline \multirow[b]{2}{*}{ Tag sequence } & \multicolumn{3}{|c|}{ Number of tags per library* } & \multirow[b]{2}{*}{$\begin{array}{l}\text { UnıGene } \\
\text { cluster**** }\end{array}$} & \multirow[b]{2}{*}{ Cluster name } \\
\hline & TNF- $\alpha$ & Restıng & P-value** & & \\
\hline GAAGCAGGAC & 5 & 0 & 00332 & Hs 180370 & cofilın 1 (non-muscle) \\
\hline GACTTCACTT & 5 & 0 & 00332 & Hs 77356 & transferrın receptor ( $p 90, C D 71)$ \\
\hline GATGTGCACT & 5 & 0 & 00332 & - & No match \\
\hline GCTGGCTGGC & 5 & 0 & 00332 & Hs 108809 & $\begin{array}{l}\text { chaperonın containıng TCP1, } \\
\text { subunit } 7 \text { (eta) }\end{array}$ \\
\hline TAGGGCAATC & 5 & 0 & 00332 & Hs 180139 & $\begin{array}{l}\text { SMT3 (suppressor of mif two 3, yeast) } \\
\text { homolog } 2\end{array}$ \\
\hline TGAGTCTGGC & 5 & 0 & 00332 & $\mathrm{Hs} 4055$ & core promorer element bindıng proteın \\
\hline CACAAACGGT & 29 & 45 & 00341 & Hs 195453 & $\begin{array}{l}\text { ribosomal proteın } \$ 27 \\
\text { (metallopanstimulın I) }\end{array}$ \\
\hline AGGGTGGTGA & 7 & 1 & 00368 & Hs 44036 & ESTs \\
\hline TGACTGGCAG & 7 & 1 & 00368 & Hs 119663 & $\begin{array}{l}\text { CD59 antigen p18 } 20 \text { (antigen identified } \\
\text { by monoclonal antibodies } 163 \mathrm{~A} \text {, EJI6, } \\
\text { EJ30, EL32 and G344) }\end{array}$ \\
\hline TGTTTATCCT & 3 & 10 & 00409 & Hs 78888 & $\begin{array}{l}\text { diazepam bindıng inhibitor } \\
\text { (GABA receptor modulator } \\
\text { acyl-Coenzyme A bindıng proteın) }\end{array}$ \\
\hline CTCATAGCAG & 16 & 28 & 00417 & Hs 119252 & tumor protein, translationally controlled 1 \\
\hline
\end{tabular}

Most genes that are expressed at high levels in keratınocytes, as determıned through SAGE, are those that are involved in cellular energy metabolism and protein synthesıs (data not shown), which is in line with previous reports ${ }^{11} 32$ Keratınocytes, however, follow a unique differentiation pathway that can be monitored by the expression of genes that are associated with various stages of differentiation, and that also play an important part in cytoskeleton assembly and epidermal barrier function Our data indicate that this class of genes is abundantly expressed in our librartes (at least $6 \%$ of all transcripts) and is not appreciably affected by TNF- $\alpha$ stımulation Genes that are believed to be involved in host defense and protection are also expressed at substantial levels (about $2 \%$ of all transcripts) One of the intriguing aspects of TNF- $\alpha$ is that it is able to either induce apoptosis or promote survival through a pathway that involves the activation of NF- $\kappa B^{27}$ Several genes that are involved in either pathway have been identified in our libraries A more detailed overview of tags belonging to these functional classes of genes and their regulation in aberrant, TNF- $\alpha$ induced differentiation will be presented below.

\section{Genes coding for cytoskeletal and differentiation-related proteins}

Genes that are associated with cytoskeleton assembly and epidermal barrier function in keratınocytes are abundantly expressed, irrespective of stımulation (TABLE 4) Cytokeratins make up an important part of the cytoskeleton, and different cytokeratins are expressed at varıous stages of differentiation In both SAGE librarıes, CK5 and CK14 are among the most abundantly expressed genes CK14 showed the highest expression of all keratins in 


\begin{tabular}{|c|c|c|c|c|}
\hline \multirow[b]{2}{*}{ Tag Sequence } & \multicolumn{2}{|c|}{ Frequency $(\%)^{*}$} & \multicolumn{2}{|c|}{$\begin{array}{l}\text { Fold up-/down- } \\
\text { regulation }\end{array}$} \\
\hline & + TNF & - TNF & $+\mathrm{TNF}^{* *}$ & Gene \\
\hline GATGTGCACG & 1.75 & 1.41 & 1.2 & Cytokeratın 14*** \\
\hline СГТССТTGCC & 1.30 & 145 & -11 & Cytokeratın 17 \\
\hline AAAGCACAAG & 0.80 & 046 & 1.7 & Cytokeratin $6^{* * *}$ \\
\hline CCCTTGAGGA & 0.60 & 089 & -15 & Small proline-rich protein $1^{* * *}$ \\
\hline GAAAACAAAG & 0.50 & 0.77 & -1.5 & Cytokeratın $10^{* * *}$ \\
\hline ACATTTCAAA & 0.43 & 049 & -11 & Cytokeratın 1 \\
\hline GССССТGСТG & 0.39 & 036 & 11 & Cytokeratın 5 \\
\hline GGCTTCTAAC & 0.13 & 0.12 & 1.1 & Small prolıne rich protein II \\
\hline CAGCTGTCCC & 0.10 & 009 & 11 & Cytokeratın 16 \\
\hline ТСТСТТТААТ & 0.05 & 0.09 & -1.8 & Involucrin \\
\hline CTGCTCAATG & 0.04 & 003 & 13 & Transglutamınase 1 \\
\hline TCTTAACCTA & 0.008 & 0.00 & $\mathrm{ND}^{* * * *}$ & Loricrin \\
\hline
\end{tabular}

* Frequency as percentage of the toral number of tags in a given library

** Based on relative frequencies of a particular sequence tag

*** Significantly up- or downregulated, $p<005$

****ND, not determıned: no meaningful ratıo due to low frequency.

the combined librarıes, accounting for more than $1.5 \%$ of all transcripts. CK1 and CK10 are also found at high levels, indicating that the model system allows a considerable degree of differentiation. Expression levels of these cytokeratins did not markedly differ between the two libraries (less than 1.5-fold), although the difference was significant for CK10 and CK14. CK6b, CK16, and CK17 are in vivo usually seen following stress and during hyperproliferation ", but are invariably found in cultured keratinocytes. In both libraries CK17 was highly expressed at equal levels, whereas CKGb was significantly upregulated after TNF- $\alpha$ stimulation. CK2e, a cytokeratin found in the stratum granulosum of normal skin "i was not detected in either library. Small proline-rich proteins I and II (also referred to as cornifins) make up an important structural part of the cornified layer and were found at high levels in both libraries. Transglutaminase 1 , an enzyme involved in protein cross-linking durıng assembly of the cornified layer, and involucrin were found in both libraries at moderate levels. Loricrin and filaggrin, two major components of the stratum corneum ${ }^{15}{ }^{36}$, were nor detected in the library of normally differentiated cells, although one tag for loricrin was found in the library from TNF- $\alpha$ stımulated cells. The absence of CK2e, filaggrin, and a substantial number of tags for loricrin is consistent with the absence of $d$ morphologically recognizable stratum granulosum in submerged cultures.

\section{Genes involved in host protection}

In addition to the formation of a physical skun barrier, keratinocytes are involved in the protection of the host against microbial atrack, and in the protection of the tissue against self proteinases derived from inflammatory cells. The presence of several antimicrobial pro- 


\begin{tabular}{|c|c|c|c|c|}
\hline \multirow[b]{2}{*}{ Tag Sequence } & \multicolumn{2}{|c|}{ Frequency (\%) } & \multicolumn{2}{|c|}{$\begin{array}{l}\text { Fold up-/down- } \\
\text { regulation }\end{array}$} \\
\hline & $+\mathrm{TNF}$ & -TNF & + TNF & Gene name \\
\hline GTGGCCACGG & 0.53 & 026 & 20 & MRP-14* \\
\hline TGTGGGAAAT & 042 & 0.34 & 1.2 & SLPI \\
\hline ATCCTTGCTG & 0.31 & 050 & -1.6 & Cystarin $A^{*}$ \\
\hline TACCTGCAGA & 0.26 & 0.09 & 2.9 & MRP-8* \\
\hline TTGAATCCCC & 017 & 019 & -11 & SKALP \\
\hline ATGAGCTGAC & 013 & 0.13 & 1 & Cystatin B \\
\hline GTTCCCTGGC & 010 & 0.09 & 1.1 & Ubiquicidın \\
\hline GTGGAGGGCA & 009 & 0.04 & 23 & Cystatın M \\
\hline TGCCTGCACC & 007 & 0.07 & 1 & Cystatin C \\
\hline CACTCCAGCC & 0015 & 0 & $\mathrm{ND}^{* *}$ & Carhepsin G \\
\hline AGAACTTCCT & 0008 & 0015 & -2 & $\beta$-Defensın 1 \\
\hline TAAACCAAAT & 0.008 & 0 & $\mathrm{ND}^{* *}$ & $\beta$-Defensin 2 \\
\hline
\end{tabular}

* Transcripts with a significant difference in expression level after TNF- $\alpha$ stımulation, $p<0.05$.

** ND, not determined. no meaningful ratıo due to low frequency.

teins like skın-derıved anti-leukoproteinase (SKALP/elafin), secretory leukoprotease Inhibitor (SLPI), $\beta$-defensin 2, and cystatın A has been described in epidermis. In addition, SKALP/elafin, SLPI, and cystatin A are also proteinase inhibitors. Remarkably, this class of genes was highly expressed in our librarıes (TABLE 5). High levels of SLPI, SKALP/elafin, MRP-8 and MRP-14 (also referred to as calgranulins) and various cystatins were found (almost $2 \%$ of the total number of tags). The expression of these cystatins, except cystatin $\mathrm{A}$, has nor been reported previously for adult human keratinocytes. The recently discovered cystatin $\mathrm{M}^{30}$ and cystatins $B$ and $C$ are also expressed in keratinocytes. For cystatın $\mathrm{C}$ two tags were found that could be assigned to the cystatin $\mathrm{C}$ UnıGene cluster (Hs.135084). One tag that corresponds to the known cDNA sequence is nor differentially expressed, whereas another tag assigned to the cystatin $\mathrm{C}$ cluster on the basis of assembled ESTs (tag-to-gene analysis, http://www.ncbi.nlm.nh.gov/SAGE/SAGErag.cgi) is highly upregulated after TNF- $\alpha$ sumulation (see TABLE 3). Other genes that play a part in host protecrion, such as SKALP and SLPI, are expressed in both libraries at high levels. These proteins are inhibitors of leukocyte-derived proteinases ${ }^{5} 30{ }^{37}{ }^{38}$, and SLPI has both ant1microbial and ant1-viral properties ${ }^{*}$. SKALP/elafin is a member of the recently described trappin gene family ${ }^{31}$ and is involved in the protection against microbial infection ${ }^{40}$. MRPs are calcium-binding proteins, and it has been demonstrated that MRP-8 and MRP14 can form a heterodimer and have anti-microbial activity in vitro ${ }^{41-43}$. Boch proteins are significantly upregulated after TNF- $\alpha$ stımulation. Ubıquicidın, a new anti-microbial protein recently described in murine macrophages ${ }^{44}$, is abundantly expressed in cultured keratinocytes, irrespective of sumulation. It exists as a post-translational modification of the fau gene product and has not been described previously in human epithelial cells. A tag corresponding to the human fau gene was found at significant levels in both SAGE libraries. Members of the serprocidin family ${ }^{15}$, which are abundantly expressed in human 
Tag Sequence

CTCCTCACCT

GCAAAACCCC

CCACTACACT

AAAGTCTAGA

GAGGCGCTGG

TTAATTGGGA

ACAATCATCC

GGCATTTTTC

ATGCCTTTTT

ACCGGTACTG

ACСАAАГГАA

ACCATCCTGC

TTCTAGTCTG
Number of tags

$\begin{array}{rrl}10 & 10 & \text { Bak } \\ 6 & 2 & \text { HVEM-L/LIGHT } \\ 3 & 2 & \text { TRAIL } \\ 1 & 0 & \text { Bcl-1 } \\ 1 & 0 & \text { Bad } \\ 1 & 1 & \text { Bag-1 } \\ 1 & 0 & \text { Bcl-2 } \\ 1 & 3 & \text { Bax } \\ 0 & 1 & \text { Nbk/B k } \\ 1 & 0 & \text { TRAIL-R2 } \\ 0 & 1 & \text { TRAIL-R2 (variant) } \\ 1 & 0 & \text { IEX-1 } \\ 0 & 1 & \text { hIAP-2 }\end{array}$

- Difference between expression levels of genes associated with apoptosis and survival was statistically nor significant ( $p<0$ 05)

neutrophils, were not found with the notable exception of the proteinase/antımicrobial cathepsin $G$, of which two tags were found in the library of TNF- $\alpha$ stimulated keratinocytes. $\beta$-defensins 1 and 2 were found at low levels after TNF- $\alpha$ stimulation, whereas $\beta$-defensin 1 was only present in normally differentiared keratınocytes.

\section{Genes involved in apoptosis and survival}

Exposure of target cells to TNF- $\alpha$ can etcher lead to apoptosis or the induction of gene expression leading to cell survival. TNF- $\alpha$ can induce apoptosis by triggering a proteolytic cascade through its receptor TNF-R1, eventually leading to DNA fragmentation and cell death. In our hands TNF- $\alpha$ did not induce apoptosis in keratinocytes when applied at concentrations up to $25 \mathrm{ng} / \mathrm{ml}$. Two inhibitors of TNF-mediated apoptosis were, however, detected: IEX-1 and cellular inhibitor of apoptosis protein 2 (TABLE 6). IEX-1 was originally identıfied in keratınocytes, and its expression is mediated through NF- $\kappa B^{~}{ }^{8}$. IEX-1 is only represented by one tag after TNF- $\alpha$ stimulation. Clearly, such small differences do not allow conclusions on differential expression; however, when IEX-1 expression was checked by Northern blot analysis, a clear signal was obtanned showing a strong upregularion following TNF- $\alpha$ stimulation (data not shown). Of special interest is the presence of TNF-related apoptosis inducing ligand (TRAIL) in both libraries as well as herpes virus entry mediator ligand (HVEM-L), as their gene products can induce apoptosis in varıous transformed and tumor cell lines ${ }^{46}{ }^{49}$, but can also induce the NF- $K B$ pathway in various cell types ${ }^{50} " 1$ albeit to a lesser extent than TNF- $\alpha$. One of the receptors for TRAIL, TRAIL receptor 2 (also known as KILLER and death receptor 5), was also identified in both libraries (TABLE 6).

Apoptosis can also be the result of a balance between the expression of pro-apoptotic and antı-apoptotıc genes of the $\mathrm{Bcl}$ family, which appeared to be expressed in our librarıes ar surprisingly high levels (TABLE 6). It has been shown that Bak, a pro-apoptoric gene, is expressed in both normal and inflamed skun ", most promınently in the granular layer, just before the 


\section{Discussion}

We have applied SAGE technology in order to make a comprehensive study of keratinocyte gene expression in vitro. The major goal was to obtain insight into the repertoire of expressed genes in these cells, and a second goal was to examine the long-term, secondary effect of a pro-inflammatory cytokine, as it is known that epidermal differentiation is altered in the context of inflammation. SAGE allows the generation of a catalog of thousands of expressed genes, without any prior knowledge of the cell's repertoire, and has the additional advantage of discovery of new genes. When large numbers of tags are sequenced to obtain a several-fold coverage of the expressed genes, as was performed in yeast, a socalled transcriptome is obtained ${ }^{31}$. In our study a total of 25,000 tags were analyzed in the combined libraries that allows the identification of more than 10,000 expressed genes in keratinocytes using a well-defined culture system (FIGURE 2); however, a limitation of the approach is that only a small part of the genes are expressed at sufficient levels to allow a statistically reliable comparison between the normal and aberrantly differentiated cells. This problem can be overcome by simply sequencing more tags, i.e., by increasing the sample size. Nevertheless, a wealth of data is generated in our analysis because: (i) it is has uncovered many genes not previously known to be expressed by keratinocytes; (ii) differential gene expression has been demonstrated for 90 genes after prolonged TNF- $\alpha$ stimulation; and (iii) several tags have been identified that have no match in the public databases, and thus potentially represent new genes.

We have sought to analyze gene expression in keratinocytes in a submerged culture system, and we compared gene expression of normally differentiated keratinocytes with those stimulated with TNF- $\alpha$, a potent pro-inflammatory cytokine which is likely to play an important part in various pathologic conditions of the skin. It should be noted that TNF- $\alpha$ is able to induce a response in the target cell within minutes, leading to rapid changes at the transcriptional level; however, in this study we have chosen to analyze the indirect effects of TNF- $\alpha$ stimulation after 48 hrs of addition to cultured keratinocytes, as a model system to examine the long-term effects of an inflammatory stimulus on keratinocyte gene expression. The results indicate that at least 10,000 genes are expressed by keratinocytes, irrespective of stimulation, most of which are involved in protein synthesis and metabolism (data not shown). Based on the results of 2D-PAGE and large-scale protein sequencing ${ }^{14}$ it has been established that in keratinocytes 2,315 gene products can be identified at the protein level. Allowing for redundancy and isoforms, over 100 unique genes could be attribured to these 2315 sequenced proteins according to UniGene cluster analysis, thus identifying more than 100 unique genes that are expressed at the protein level (http://biobase.dk/cgi-bin/celis/). This number is far less than the number of expressed genes in our two SAGE libraries. Gygi et al. "s, however, have shown that, although many genes are found to be differentially expressed through SAGE and Northern blot hybridization in yeast during the cell cycle ", expression levels of genes at the protein level can greatly differ from the SAGE data. This finding implies that one should be cautious in the interpretation of data concerning mRNA levels, and that the catalog generated through SAGE should only be considered a rough indication of which genes are active, and is by no means conclusive with regard to their presence at the protein level. Furthermore, only 90 genes or approximately $1 \%$ of all genes identified show a significant upregulation or downregulation after TNF- $\alpha$ stimulation, indicating that relatively few genes are involved in the profound phenotypic and biochemical changes that are usually seen after cytokine-induced aberrant differentiation. The relative amount of differentially expressed genes appears to be 


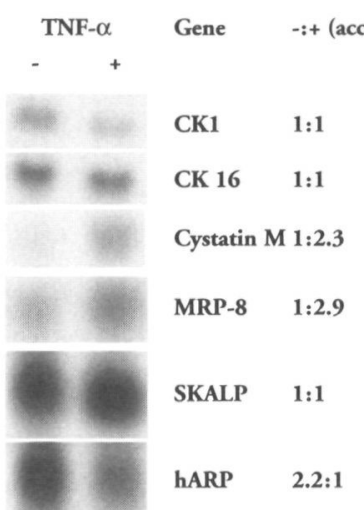

FIGURE 3 Verification of SAGE data by Northern blot hybridization. A) Ten micrograms of total RNA from which either library was derived was loaded on a $1 \%$ agarose gel, blotted to nitrocellulose membrane and hybridized with probes for the genes indicated. B) Equal loading was verified by methylene blue staining of $28 \mathrm{~S}$ and $18 \mathrm{~S}$ rRNA. CK, cytokeratin; hARP, human acidic ribosomal protein; MRP, migration inhibitory factor-related protein; ND, not determined: no meaningful ratio obtained due to low frequency; NS: not significant according to SAGE data.

final steps that lead to the formation of the cornified layer. Bak is also expressed in our culture model, irrespective of stimulation. The pro-apoptotic proteins Bad and Bax are also expressed, albeit at lower levels. One pro-apoptotic protein, Nbk/Bik, has never been described in keratinocytes; its tag occurs once in the library from normally differentiated cells. Bag-1 is a potent inhibitor of apoptosis and Fas-induced cell death ${ }^{53}$, and its expression has never been described in keratinocytes either.

\section{Verification of SAGE data by Northern blot analysis}

Although the high expression levels of several genes in the SAGE libraries (already known from epidermis and cultured keratinocytes) suggested that the data obtained were valid at least for the high scoring tags, we wanted to verify some of the data by an independent method. To this end we selected various tags corresponding with genes for which probes were available in our lab, or for which probes could be generated by means of reverse transcription-PCR. Primers for reverse transcription-PCR are based on mRNA sequences as deposited in GenBank. Reverse transcription-PCR products were cloned into the pGEM-T vector and PCR products were checked by sequence analysis. For Northern blotting, RNA was used from which the two libraries are derived, and equal loading was verified by the staining of ribosomal RNA with methylene blue before Northern blot hybridization (FIGURE 3B). As seen in FIGURE 3A, CK1 and CK16 are expressed in resting and stimulated cells at similar levels, correlating well with SAGE data. MRP-8 is upregulated almost 3-fold according to the SAGE data ( $<<0.01)$, which was confirmed by Northern blot hybridization. Human acidic ribosomal protein $\mathrm{P} 0$, a housekeeping gene, appears to be downregulated more than 2-fold after TNF- $\alpha$ stimulation ( $\mathrm{p}<0.001$ ), which is also confirmed by Northern blot hybridization. IEX-1, a gene previously shown to be upregulated by TNF- $\alpha^{54}$, was only represented by one tag after TNF- $\alpha$ stimulation. Northern blot hybridization, however, revealed that IEX-1 is indeed markedly upregulated (data not shown). 
in line with other reports in which SAGE was used as a means to study gene expression in the comparison of normal colon and cancer cells, more than 500 genes of 49,000 different genes identified, or about $1 \%$, appeared to be differentially expressed ${ }^{56}$ In the case of p53-induced gene expression, only 34 of 7,202 genes identified, or less than $05 \%$, appear to be markedly, $1 \mathrm{e}$, more than 10-fold, upregulated or downregulated 57 Interestingly, many of the differentially expressed tags are present in ESTs that have been assigned to UniGene clusters of known genes (TABLE 3) It is clear from the UniGene clusters that various different tags can represent a single gene, as is the case for tags AGAGGTGTAG and CGCGTCACTA of which the corresponding ESTs have been assigned to the UniGene cluster of cystatin C, as has the tag TGCCTGCACC, which also corresponds with the original mRNA in GenBank (accession number X05607) This may be the result of alternative polyadenylation, alternative splicing, or polymorphisms in the mRNA from which these tags are derived One should also bear in mind that ESTs are in general poorly characterized, and that tags can incorrectly be assigned to a particular UniGene cluster as a result of sequencing artifacts It should be noted that UniGene is constantly evolving, and that the assignment of tags to genes may change over tıme, as more data become available from the Human Genome Project and the characterization of ESTs A minority of the identified tags corresponds with several different genes Two prominent examples are the tags AAAAAAAAAA and CCTGTAATCC, which match with multıple UnıGene clusters This may be due to the presence of conserved sequences and common repeats in the $3^{\prime}$ untranslated regions of various mRNA Independent assays, e $g$, Northern blotung, are then needed to ascertan from which gene, or combination of genes, the observed tags are derived Positive identification of the corresponding genes, and their biologic significance in aberrant TNF- $\alpha$ induced differentiation awaits further investigation

Our results indicate that in this submerged keratınocyte culture model, genes involved in epidermal barrier function are expressed, predominantly associated with the early differentiation of keratinocytes, their expression is also not modified to a great extent by TNF- $\alpha$ stimulation As the cultures consist of a monolayer of basal cells with scattered differentıated cells on top ${ }^{25}$, the cyrokeratins typical for basal cells (CK5 and CK14) are highly expressed, accountung for about $2 \%$ of all transcripts CK14 was expressed at significantly higher levels ( $p<0$ 05, see also TABLE 4) after TNF- $\alpha$ stimulation, but it remains to be determined whether its slight (less than 2-fold) upregulation is biologically significant, as it is expressed in both libraries at very high levels Because there are two cell populations within the cultures (basal cells and differentiated cells), the observed difference could also reflect the relative cell numbers of each population As the expression levels of CK1 and CK10 are somewhat lower in the TNF- $\alpha$ stimulated cultures, it is very well possible that TNF- $\alpha$ stimulation has caused a minor shift in the two populations The observation that $\mathrm{CKI}$ and $\mathrm{CK} 10$ are highly expressed (about $1 \%$ of all tags) indicates that a considerable degree of differentiation has occurred in these cultures The epidermal expression of CK6b, CK16, and CK17 in vivo is usually restricted to conditions of hyperproliferation, abnormal epidermal differentiation, and wound healing, whereas these genes are always expressed in cultured keratinocytes CK6b, CK16, and CK17 are believed to be involved in keratinocyte migration at the wound edge, where they are involved in the reshuffling of the intermediate keratın filaments ${ }^{\circ}$ Only CK6b was significantly upregulated after TNF- $\alpha$ stımulation (nearly 2-fold, $\mathrm{p}<0$ 001) Other differentiation-related genes that were found include the small prolıne-rich proteıns I and II, involucrin, and transglutaminase Genes that are expressed during the late stages of differentiation are either absent, as is the case for filaggrin and $\mathrm{CK} 2 \mathrm{e}$, or hardly present, such as lonicrin From these data we can conclude that the culture model used here has some characteristics of normal epidermis, but 
is still very similar to that of psorıatic epidermis, which is known to be posıtive for CK6, CK16, and CK17, and where a morphologically recognizable granular layer, and expression of filaggrin and loricrin is markedly reduced 5960 .

Apart from housekeeping genes and differentiation-related genes, a third functional group of proteins is abundantly expressed. This group involved in host protection, comprises proteinase inhibitors and anti-microbial proteins. In many cases these properties are found within the same molecule as in the dual function proteins SLPI ${ }^{81}$, some of the cystatins ${ }^{62}{ }^{64}$, and also SKALP/elafin ${ }^{39}{ }^{40}$. It is clear that keratinocytes invest large efforts in expression of these proteins (almost $2 \%$ of all tags), which is consistent with the function of the epidermis. Previous studies have indicated that the expression of these proteins is not restricted to cultured keratinocytes, but is also found in normal and inflamed human epidermis ${ }^{78} 6567$. As some of these molecules are known to be upregulated during inflammation in vivo, we expected an effect of TNF- $\alpha$ stimulation. This was indeed found to be the case for MRP-8 and MRP-14, a finding that was further confirmed on Northern blors. The fact that some of these molecules are already expressed at high levels, whereas in normal skin their expression is limited, further underlines that the nonstimulated culture from which the SAGE library was derived is in some respects more similar to psoriatic epidermis, as witnessed by the expression of CK6, CK16, CK17, SLPI, and SKALP/elafin. The model system using growth factor depleted medium to induce normal differentiation is sensitive to other factors such as confluency of the cultures. We have recently found that by carefully controlling these factors the expression of psoriasis-associated genes is suppressed. This makes the model system more sensitive to proinflammatory cytokines such as TNF- $\alpha$, and we found that, e.g., SKALP expression is under (indirect) control of TNF- $\alpha$ provided that the initial SKALP expression levels are low ${ }^{60}$. This suggests that, although we find significant differences between the two libraries, our study might underestimate the quantitative and qualitative effects of TNF- $\alpha$ on keratinocyte gene expression.

At this moment SAGE appears to be one of the most powerful methods for expression profiling, because in addition to yielding quantitative expression data it allows new genes to be discovered. Obviously, when the entire set of human genes is known, microarrays covering the entire genome will be the first choice for expression profiling studies. In conclusion, we think that these data provide basic, partial information on gene expression in keratinocytes and long-term differences induced by TNF- $\alpha$ stimulation. This analysis could be a first step towards a transcriptome of primary human cells, which could provide a wealth of information for future research in keratinocyte biology.

\section{Acknowledgements}

We gratefully thank Dr. K. Kinzler, Johns Hopkuns Oncology Center, Baltımore, MD, for the SAGE protocol and the SAGE Software Package, and Dr. Georgia Sotiropoulou, University of Patras, Greece, for providing us with the cDNA for cystatin M. This work was in part supported by the Dutch Cancer Sociery (KWF).

Note. I he libraries described in this Chapter have been deposited at the Gene Expression Ommibus (http / www ncbı nlm nıh gov/geo/) under the following accession numbers (aSMI121 SAGE library derived from cultured keratinocytes, GSM 122 SAGE library derived from INF- $\alpha$ stımulared keratınocytes Both librarıes can be accessed through the SAGE website at http//www ncbi nlm nih gov/SAGE/ 
1 Watt FM. Terminal differentiation of epıdermal keratınocyies.

Curr Opın Cell Biol 1989;1(6)-1107-15

2. Fuchs E. Epıdermal differentiation and keratın gene expression

J Cell Sc1 Suppl 1993,17·197-208

3. Eckert RL, Crish JF, Banks EB, Welter JF. The epidermis: genes on - genes off. J Invest Dermatol 1997;109(4):501-9.

4 Orren HG, Bor B, Ververs C, Verdonck LF, De Boer M, De Gast GC Alloantigen-specific T-cell anergy induced by human keratinocytes is abrogated upon loss of cell-cell contact Immunology 1996;88(2),214-9

5. Pfundt $R$, van Ruissen $F$, van Vlijmen-Willems $I M$, Alkemade HA, Zeeuwen PL, Jap PH, et al. Constitutive and inducible expression of SKALP/elafin provides antI- elastase defense in human epithelıa.

J Clın Invest 1996;98(6):1389-99.

6 Frohm M, Agerberth B, Ahangarı G, Stahle-Backdahl M, Liden S, Wigzell H, et al The expression of the gene coding for the antibacterial peptide LL-37 is induced in human keratinocytes during inflammatory disorders J Bıl Chem 1997;272(24):15258-63

7 Harder J, Bartels J, Christophers E, Schroder JM. A pepude antibıotic from human skin Nature 1997;387(6636) 861

8 Wingens $M$, van Bergen BH, Hiemstra PS, Meis JF, van Vlymen-Willems IM, Zeeuwen PL, et al Induction of SLPI (ALP/HUSI-I) un epidermal keratınocytes J Invest Dermatol 1998.11 1(6).996-1002.

9 Kupper TS. The actuvated keratınocyte a model for inducible cyrokine production by non-bone marrow-derived cells in cutaneous inflammatory and immune responses J Invest Dermarol 1990,94(6 Suppl).146S-150S.

10 Barker JN, Mitra RS, Griffiths CE, Dixıt VM, Nickoloff BJ Keraunocyres as inıtıators of inflammanon Lancer 1991;337(8735)-211-4.

11 Eckert RL Structure, function, and differentiation of the keratunocyte Physiol Rev 1989;69(4) 1316-46

12 Fuchs $E$ Keratıns and the skan Annu Rev Cell Dev Biol 1995,11.123-53.
13 Eckert RL, Crish JF, Robinson NA The epıdermal keratınocyre as a model for the study of gene regulation and cell differentiation Physiol Rev 1997;77(2):397-424.

14 Celıs JE, Rasmussen HH, Gromov P, Olsen E, Madsen P, Leffers $\mathrm{H}, \mathrm{et}$ al. The human keratınocyte two-dimensional gel protein database (update 1995). mapping components of signal transduction pathways. Electrophoresıs 1995;16(12)-2177-240

15. Kan AB, Taichman LB. A partual catalog of proteins secreted by epidermal keratinocytes In culcure. J Invest Dermatol 1999;112(5):8 18-21.

16 Konıshı K. Morıshıma Y, Ueda E, Kube Y, Nonomura K, Yamanıshı K, et al. Catalogıng of the genes expressed in human keratınocytes: analysss of 607 randomly ssolated cDNA sequences. Bıochem Bıophys Res Commun 1994;202(2):976-83.

17 Frank S, Werner S The human homologue of the yeast $\mathrm{CHLl}$ gene is a novel kerarınocyte growth factor-regulated gene. J Biol Chem 1996;271(40) 24337-40

18. Frank $S$, Munz B, Werner $S$. The human homologue of a bovine non-selenıum glutathıone peroxudase is a novel keratınocyte growth factor-regulated gene Oncogene 1997;14(8):915-21

19. Munz B, Gerke V, Gllızer R, Werner S Differential expression of the calpactin I subunits annexun II and Pl 1 in cultured kerarınocytes and during wound reparr

J Invest Dermatol 1997,108(3).307-12

20. Ruvas MV, Jarvıs ED, Morısakı S, Carbonaro H, Gottlieb AB, Krueger JG Identification of aberrantly regulated genes in diseased skun using the cDNA differential display technıque. J Invest Dermatol 1997,108(2):188-94

21. Rurberg SE, Lee EJ, Hansen LH, Glick AB, Yuspa SH Identıfication of differentıally expressed genes in chemically induced skun tumors Mol Carcinog 1997;20(1):88-98

22 DiSepıo D, Ghosn C, Eckert RL, Deucher A, Robinson N, Duvic $M_{1}$ et al Identification and characterization of a retınold-Induced class II rumor suppressor/growth regulatory gene Proc Nad Acad Scı U S A 1998,95(25) 14811-5. 
23 Trenkle T, Welsh J, Jung B, Mathieu-Daude F, McClelland M. Non-stoichiomerric reduced complexty probes for cDNA arrays Nucleıc Acıds Res 1998;26(17).3883-91

24 Velculescu VE, Zhang L, Vogelstein $B$ Kunzler KW. Serıa analysıs of gene expression Science 1995:270(5235):484-7.

25 Van Russen F, de Jongh G], Zeeuwen PL. Van Erp PE, Madsen P, Schalkwijk J. Induction of normal and psoriatic phenotypes in submerged keratınocyte cultures.

J Cell Physiol 1996;168(2)-442-52.

26. Schulze-Osthoff $K$, Ferrarı D, Los $M$, Wesselborg S, Perer ME. Apoptosis signaling by deach receptors

Eur J Biochem 1998;254(3).439-59.

27. Wang CY, Mayo MW, Korneluk RG, Goeddel DV, Baldwin AS, Jr. NF-kappaB antiapoptosis: induction of TRAF1 and TRAF2 and c-LAP1 and C- LAP2 to suppress caspase-8 activation Science 1998;281(5383) ·1680-3

28. Wu MX, Ao Z, Prasad KV, Wu R, Schlossman SF. IEX-1L, an apoptosis inhibitor involved in NF-kappaB-mediated cell survival. Science 1998;281(5379) ·998-1001.

29. Ausubel FM. Current protocols in molecular biology. Brooklyn, N Y Greene Publıshıng Associates; 1987.

30. Soturopoulou G, Anisowic A, Sager R Idenufication, cloning, and characterization of cystaun $M$, a novel cysteine proteinase inhibitor, down-regulated in breast cancer. J Bıol Chem 1997;272(2):903-10

31. Velculescu VE, Zhang L, Zhou W, Vogelstein J, Basrai MA, Bassett DE, Jr., et al. Characterization of the yeast transcriptome.

Cell 1997;88(2):243-51.

32. Chen H, Centola $M$, Alschul SF, Metzger $H$. Characterization of gene expression in resung and acuvated mast cells J Exp Med 1998;188(9):1657-68.

33. Leıgh IM, Navsaria H, Purkus PE, McKay LA Bowden PE, Ruddle PN. Kerauns (K16 and K17) as markers of keratınocyte hyperproliferation in psortasis in vivo and in vitro.

Br J Dermatol 1995;133(4):501-11.
34 Steinert PM, Marekov LN The proteins elafin, filaggrın, keratın intermediate filaments, lonerın, and small proline-rich proteins 1 and 2 are sodipeptide cross-linked components of the human epidermal cornified cell envelope. J Bıol Chem 1995;270(30):17702-11

35. Steven AC, Steinert PM Protein composition of cornufied cell envelopes of epidermal keratunocytes. J Cell Sa 1994,107(Pt 2):693-700.

36 Candi E, Melıno G, Meı G, Taresa E, Chung SI, Marekov LN, et al Brochemical, structural, and transglutaminase substrate properties of human loricrın, the major epidermal cornıfied cell envelope prorein.

J Biol Chem 1995;270(44) $26382-90$

37. Molhuizen HO, Alkemade HA, Zeeuwen PL, de Jongh GJ, Wieringa B, Schalkwijk J SKALP/elafin an elastase inhubitor from cultured human keratınocytes Purıfication, cDNA sequence, and evidence for transglutaminase cross- linking

J Biol Chem 1993;268(16):12028-32

38 Zeeuwen PL, Hendriks W, de Jong WW, Schalkwıjk J Identufication and sequence analysıs of rwo new members of the SKALP/elafin and SPAl-2 gene family. Biochemical properties of the transglutaminase substrate motif and suggestions for a new nomenclature.

J Biol Chem 1997;272(33).20471-8.

39 Schalkwijk J, Wiedow O, Hirose S The trappin gene family. proteins defined by an N-terminal transglutaminase substrate domain and a C-terminal four-disulphide core. Biochem ] 1999;340(Pr 3)·569-577

40. Simpson AJ, Maxwell AJ, Goven JR, Haslett C, Sallenave JM. Elafin (elastase-specific ınhibitor) has antı-microbıal actuvity against gram-positive and gram-negative respiratory pachogens FEBS Lett 1999;452(3):309-13

41 Brandzaeg P, Gabrielsen TO, Dale I, Muller F, Steınbakk M, Fagerhol MK. The leucocyte proteın L1 (calprotectin)' a putative nonspecific defence factor at epichelial surfaces. Adv Exp Med Bıol 1995-201-6

42. Santhanagopalan V, Hahn BL, Dunn BE, Weissner JH, Sohnle PG Antumicrobial actuvity of calprotectin isolated from human empyerna flud supernatants. Clin Immunol Immunopathol 1995;76(3 Pt 1):285-90. 
43. Loomans HJ, Hahn BL, Li QQ, Phadnis SH, Sohnle PG. Histıdine-based zinc-binding sequences and the antımicrobıal actuvicy of calprorectun J Infect Dis 1998:177(3)·812-4

44. Hiemstra PS, van den Barselaar MT, Roest M, Nibberıng PH, van Furth R. Ubıquicıdın, a novel murine microbicidal protein present in the cytosolic fraction of macrophages J Leukoc Bıol 1999;66(3) 423-8.

45. Nathan CF, Gabay J. Antımicrobıal mechanisms in macrophages. In. Van Furth $R$, ediror. Mononuclear phagocytes ' biology of monocytes and macrophages. Dordrecht ; Boston Kluwer Academic Publishers; 1992. p. 259-267.

46 Wiley SR, Schooley K, Smolak PJ, Din WS, Huang CP, Nıcholl JK, et al Identification and characterization of a new member of the TNF famly that induces apoptosis. Immunity 1995:3(6):673-82.

47. Pittı RM, Marsters SA, Ruppert S, Donahue CJ, Moore A, Ashkenazi A Induction of apoprosis by Apo-2 ligand, a new member of the tumor necrosis factor cyrokine family. J Biol Chem 1996;271(22):12687-90.

48. Maurı DN, Ebner R, Montgomery RI, Kochel KD, Cheung TC, Yu GL, et al LIGHT, a new member of the TNF superfamily, and lymphotoxin alpha are ligands for herpesvirus entry mediator. Immunity 1998,8(1):21-30.

49 Zha Y, Guo R, Hsu TL, Yu GL, Nı J, Kwon BS, et al. LIGHT, a novel ligand for lymphotoxin beta receptor and TR2/HVEM induces apoptosis and suppresses in vivo tumor formation via gene rransfer J Clın Invest 1998;102(6) $1142-51$

50. Chaudhary PM, Eby M, Jasmın A, Bookwalter A, Murray J, Hood L Death receptor 5, a new member of the TNFR family, and DR4 induce FADD- dependent apoptosis and activate the NF-kappaB pathway. Immunity 1997,7(6).821-30.

51. Harrop JA, McDonnell PC, Brigham-Burke $M$, Lyn SD, Minton J, Tan KB, et al. Herpesvirus entry mediator ligand (HVEM-L), a novel ligand for HVEM/TR2, stimulates proliferation of T cells and inhibits HT29 cell growth. J Bıl Chem 1998;273(42) 27548-56

52. Tomkova H, Fujımoto W, Arata J. Expression of bcl-2 antagonıst bak in inflanmatory and neoplasuc skin diseases.

Br J Dermatol 1997;137(5)·703-8
53. Takayama S, Saro T, Krajewskı S, Kochel K, Irıe $S$, Millan JA, et al. Cloning and functional analysis of BAG-1. a novel Bcl-2-binding proteın with anti-cell death activity Cell 1995;80(2) $279-84$

54. Kondratyev AD, Chung KN, Jung MO. Identification and characterization of a radiation-inducible glycosylared human early-response gene Cancer Res 1996;56(7) $1498-502$

55. Gyg 1 SP, Rochon Y, Franza BR, Aebersold R. Correlation between protein and mRNA abundance in yeast. Mol Cell Biol 1999;19(3) $1720-30$

56. Zhang L, Zhou W, Velculescu VE, Kern SE, Hruban RH, Hamilton SR, et al Gene expression profiles in normal and cancer cells. Science 1997;276(5316):1268-72

57. Polyak K, Xıa Y, Zweier JL, Kınzler KW, Vogelstein B A model for p53-induced apoptosis Narure 1997,389(6648).300-5.

58. Paladin RD, Takahashı $K$, Bravo NS, Coulombe PA Onset of re-epithelialization after skin injury correlates with a reorganization of keratın filaments in wound edge keratınocytes defining a potentıal role for keratın 16

J Cell Bıol 1996;132(3):381-97

59. Bernard BA, Asselineau D, Schaffar-Deshayes L, Darmon MY Abnormal sequence of expression of differentiation markers in psoriatic epidermıs Inversion of two steps in the differentiation program' J Invest Dermatol 1988,90(6).801-5

60 Ishida-Yamamoto A, Eady RA, Watt FM, Roop DR, Hohl D, I Izuka H. Immunoelectron microscopic analysis of cornified cell envelope formation in normal and psoriatic epidermis. J Histochem Cytochem 1996;44(2)-167-75.

61. Wiedow O, Harder J, Bartels J, Streit V, Christophers E Antileukoprotease in human skin: an antibiouc pepude consututively produced by keratinocytes Biochem Biophys Res Commun 1998;248(3):904-9.

62. Bjorck L. Proteınase ınhibırion, Immunoglobulinbınding proreıns and a novel antimıcrobıal princıple. Mol Microbiol 1990;4(9) $1439-42$

63. Blankenvoorde $M F$, van't Hof W, Walgreen-Weterings E, van Steenbergen TJ, Brand HS, Veerman EC, et al. Cysratın and cystatin-derived pepudes have antibacterıal activity against the pathogen Porphyromonas gingivalis Biol Chem 1998;379(11):1371-5 
64 Takahashi M, Tezuka T, Katunuma N. Inhıbition of growth and cysteine proteinase activity of Staphylococcus aureus V8 by phosphorylated cystatın alpha in skın cornified envelope FEBS Lett 1994;355(3)·275-8.

65 Takahashı M, Tezuka T, Karunuma N.

Phosphorylated cystatun alpha is a natural substrate of epidermal transglutaminase for formation of skun cornified envelope. FEBS Lett 1992;308(1)·79-82.

66 Schalkwijk J, van Vlımen IM, Alkemade JA, de Jongh GJ Immunohistochemical localızation of SKALP/elafin in psoriatic epidermıs. I J Invest Dermatol 1993;100(4) 390-3.

67 Schroder JM, Harder J Human bera-defensin-2. Inr J Bıochem Cell Bıol 1999;31(6):645-51

68 Pfundt $R$, Wingens $M$, Bergers $M$, Zweers $M$, Frenken $M$, Schalkwık J. TNF-alpha and serum induce SKALP/elafin gene oxpression in human keratınocytes by a 38 MAP kınase-dependent parhway. Arch Dermatol Res 2000;292(4):180-7. 


\title{
Differential gene expression in premalignant human epidermis revealed by cluster analysis of Serial Analysis of Gene Expression (SAGE) libraries
}

\author{
Fred van Ruissen* \\ Bastiaan J.H. Jansen* \\ Gys J. de Jongh \\ Ivonne M.J.J. van Vlijmen-Willems \\ Joost Schalkwijk \\ Department of Dermatology \\ University Medical Center St. Radboud \\ PO Box 9101 \\ $6500 \mathrm{HB}$ Nijmegen \\ The Netherlands
}

*These authors contributed equally to this Chapter

This Chapter has been published online at http://www.fasebj.org/express/ and a summary has appeared as:

Van Ruissen F., Jansen B.J.H., de Jongh G.J., van Vlijmen-Willems I.M.J.J., Schalkwijk J.

Differential gene expression in premalignant human epidermis revealed by cluster analysis of

Serial Analysis of Gene Expression (SAGE) libraries. FASEB J. 2002:16(2): 246-48. 

Serial analysis of gene expression (SAGE) has been used for quantitative analysis of gene expression. We applied cluster analysis on multiple SAGE libraries derived from premalignant epidermal tissue (actinic keratosis), normal human epidermis and cultured keratinocytes. The samples were obtained from skin biopsies without contamination by der$\mathrm{mal}$ tissue or blood. A total of 60,000 transcripts (tags) were analyzed. Two-way cluster analysis was applied to both the transcripts and the tissues, resulting in separation of the cultured cells from the epidermal samples, and clustering of many, presumably co-regulated genes. Two clusters of genes, strongly upregulated in the tumor tissue compared to normal epidermis, were investigated in more detail. The differential expression of genes could be confirmed in actinic keratosis from four patients. Several of these genes have been previously associated with carcinogenesis, or are likely to be important on the basis of their presumed function. Automated literature search tools show that a subgroup of these genes is known to be co-expressed in other tissues, and is part of an epidermal differentiation gene cluster on chromosome lq21. We conclude that cluster analysis on large data sets uncovers clear partitions and correlations that could be confirmed by independent methods. We predict that these partitions will lead to biological interpretations that can be relevant for understanding the processes of carcinogenesis and tumor progression. 


\section{Introduction}

Non-melanoma skin cancers (NMSC), which preferentially occur at sun-exposed body-sites are the most common malignancies in the western world '. Because they are so common and easily accessible, they offer a unique opportunity to study the process of carcinogenesis in humans. In particular neoplasms with a squamous phenorype can be very informative because they manifest thernselves clinically in a range from benign forms (keratoacanthoma), premalignant tumors (actinic keratosis), carcinoma in situ and aggressive squamous cell carcinomas (SCC) that have the potential for local invasion and distant metastasis. Investigations on the genetic alterations in SCC have focused on the role of oncogenes and tumor suppressor genes that are involved in tumor initiation and progression. Both in humans and in animal models the role of ultraviolet (UV) induced mutations in $\mathrm{p} 53$ were shown to be early and predominant events even present in pre-cancerous lesions and normal skin ${ }^{2-4}$. The significance of activated oncogenes such as ras is less clear. At the cytogenetic level loss of heterozygosity was found at several loci, and it was suggested that only a limited number of alterations is sufficient for skin carcinogenesis '. A large number of studies have reported increased or decreased expression levels of certain genes in NMSC, that may contribute to the process of altered growth, differentiation and migration. However, this knowledge is fragmentary, often non-quantitative and does not yield comprehensive expression patterns in well-defined types of tumors compared to normal skin.

Recent developments in functional genomic technology such as micro-arrays and Serial Analysis of Gene Expression (SAGE) now allow the expression of thousands of genes to be analyzed, either in parallel or serially. SAGE is a sequencing-based approach that has been developed for quantitative analysis of gene expression ${ }^{6}$. Several laboratories, including our own, have published large-scale analyses of transcriptomes from yeast, cultured cells or organs ${ }^{7-12}$. A number of studies have reported transcriptome analysis of human tumors ${ }^{11.14}$, using SAGE or micro-array technology ${ }^{14.15}$. A potentially confounding factor in these studies is the presence of transcripts derived from normal tissue, stromal cells and infiltrating inflammatory cells, although recently a transcriptomic study was published on purified tissue ". Cluster analysis on micro-array data has recently been applied for leukemia and colon tumors, resulting in the identification of broad patterns of differentially expressed genes ${ }^{14.15}$. SAGE analysis of various tissues including thyroids, muscle, liver, brain, kidney and pancreas and glioblastomas, ovarian cancer, breast cancer, thyroid tumors and gastrointestinal tumors has been performed (for review see Yamamoto et al. ${ }^{12}$ and http://www.sagenet.org/ for recent publications). Most of these studies have described a transcriptome of one tissue, or pairwise comparison of normal and tumor tissue and the data were presented as frequency tables of expressed genes, from which the most striking differences were selected for further analysis. The purpose of the present study was to apply cluster analysis on multiple SAGE libraries, and to uncover partitions and correlations of expressed genes in purified human premalignant skin lesions. We have constructed SAGE libraries from normal epidermis and from premalignant skin lesions (actinic keratosis) of kidney transplant patients. These patients are under continuous immunosuppressive therapy, and the majority of them develop benign and premalignant skin tumors that can progress to overt malignant SCCs ${ }^{16-18}$. Here we report a comprehensive study of differential gene expression in this tumor by SAGE. Although we do not report here on the biological relevance of the data per se, our results indicate that in this way we can obtain correlations and partitions in SAGE data sets, that can be extrapolated more generally to this type of tumor. 


\section{Cells \& Cell Culture}

Primary human epidermal keratinocytes were obtained as previously described ${ }^{19} .16 \times 10^{6}$ cells were grown to confluency in $75 \mathrm{~cm}^{2}$ culture flasks under KGM, consisting of KBM $\left(0.15 \mathrm{mM} \mathrm{Ca}^{2+}\right.$; BioWhittaker, Verviers, Belgium) supplemented with ethanolamine (0.1 $\mathrm{mM}$; Sigma, St. Louis, MO), phosphoethanolamine (0.1 mM, Sigma Chemical Co., St. Louis, MO), bovine pituitary extract (BPE, $0.4 \% \mathrm{v} / \mathrm{v}$; BioWhittaker, Verviers, Belgium) epidermal growth factor (EGF, $10 \mathrm{ng} / \mathrm{ml}$; Sigma Chemical Co., St. Louis, MO), insulin (5 $\mu \mathrm{g} / \mathrm{ml}$; Sigma Chemical Co., St. Louis, MO), hydrocortisone $(0.5 \mu \mathrm{g} / \mathrm{ml}$; Collaborative Research Inc., Lexington, MA), penicillin (100U/ml; Life Technologies Inc., Gairhersburg, MD) and strepromycin ( $100 \mu \mathrm{g} / \mathrm{ml}$; Life Technologies Inc., Gaithersburg, $\mathrm{MD}$ ). Cells were switched to KGM depleted of growth factors (BPE, EGF, hydrocortisone and insulin; KGM/-GF) for 48 hrs before half of the cells ( $8 \times 10^{6}$ cells) was switched to KGM/-GF for an additıonal 48 hrs to induce normal differentiacion, while the other half was switched to KGM/-GF containing $25 \mathrm{ng} / \mathrm{ml}$ TNF- $\alpha$ (R\&D Systems, Minneapolis, $\mathrm{MN}$ ). Non-adherent cells were washed off with phosphate buffered saline (PBS), and RNA was isolated as indicared below.

\section{Biopsy material}

Punch biopsies $(4 \mathrm{~mm})$ were obtained from normal skin after surgical removal and from patients that had undergone kidney transplantation. These patients develop multiple skin tumors such as actinic keratosis and squamous cell carcinomas due to the immunosuppressive therapy. Biopsies of the unaffected skin were taken from sun-exposed sides of the forearm. In our study, three small sized lesions $(4-8 \mathrm{~mm})$ that were clinically diagnosed as actinic keratosis, were taken from each parient. All biopsies were taken after the volunteers gave their written informed consent. The local medical ethics commitree had approved the study protocol.

\section{Separation of epidermis and dermis}

To obtain epidermal sheets without admixture of contaminating cells punch biopsies were washed with phosphate buffered salıne (PBS) and treated with a proteinase preparation (dispase, $12 \mathrm{mg} / \mathrm{ml}$ in PBS) under gentle agitation. To prevent induction of new transcripts during the procedure, we performed the separation at $4^{\circ} \mathrm{C}$ in the presence of actinomycin D $(5 \mathrm{mg} / \mathrm{ml})$. Previous experiments demonstrated that treatment with dispase for 4 hours at $4^{\circ} \mathrm{C}$ resulted in efficient separation of the epidermis from the underlying dermis. One part of the epidermis and dermis was treated with $3.8 \%$ formaldehyde solution and embedded in paraffin for histological examinarion. The other part of the epidermis and a control biopsy were stored in RNAzol at $80^{\circ} \mathrm{C}$ until further use.

\section{Serial Analysis of Gene Expression}

Total RNA was isolared from homogenized epidermal sheets and cultured human keratinocytes. Purified mRNA obtained using the mRNA Capture Kit (Boehringer Mannheim) was used for doublestranded cDNA synthesis (cDNA Synthesis System; Boehringer Mannheim). We performed MicroSAGE with minor modifications as 
described by Datson et al. and Velculescu et al. ${ }^{6,20}$. In contrast to Datson et al. we used 10 $\mu \mathrm{g}$ of total RNA as starting material and performed anchoring and trapping of cDNA in two separate tubes. This procedure also allowed us to perform large-scale PCR amplifications without the need of prior amplification of the $104 \mathrm{bp}$ product. Finally, concatemers were precipitated using 35\% alcohol resulting in a reduction of DNA fragments smaller than $200 \mathrm{bp}$. Size-separation of concatemers was performed either on polyacrylamide gel or using SizeSep Columns (Pharmacia) with a cut-off around 400 bp, yielding a majority of fragments larger than $400 \mathrm{bp}$. Prior to loading on $8 \%$ polyacrylamide gel or on SizeSep columns we heated the concatemers at $65^{\circ} \mathrm{C}$ for $10 \mathrm{~min}$ followed by 2 min on ice ${ }^{21}$. Purified concatemers were subsequently cloned in the Sphl site of pZero (Invitrogen Corp., San Diego, CA) and transformed in chemically competent MAX Efficiency DH5 $\alpha$ E. coli Competent Cells (Life Technologies Inc., Gaithersburg, MD) by means of heatshock transformation, following the manufacturer's protocol. Clones were selected and colony PCR, sequencing and analysis was performed as described elsewhere ${ }^{7}$.

\section{Cluster Analysis}

Sequencing of SAGE libraries generates frequency tables that indicate how many times that a certain tag was encountered. The frequency tables of the five libraries were first normalized to expression levels per 10,000 tags and then combined in an expression level matrix. A row in this expression level matrix corresponds to a single tag (or gene, if identifrable), while each column represents a particular tissue sample from which a SAGE library was constructed. A difficulry in studying biological processes is that one wants to focus on a relatively small subset of genes while the large majority of the tags (genes) identified in a SAGE library only generates a noisy background ${ }^{15}$. We therefore reduced the data by sorting the rows of the expression matrix for information content. Rows in which the expression of the transcripts did not differ significantly were filtered out, and only the 300 most informative tags were used for further analysis. This new expression matrix of 300 tags was again normalized to obtain a matrix with column means of 1 . Subsequently, the matrix was subjected to a $Z$-transformation where $Z=(x-\mu) / \sigma_{x}$. This will yield a matrix with a row mean of 0 , and a standard deviation of 1 . After this transformation the Euclidean distance (D) is used as the dissimilarity measure. For two genes, $\mathrm{D}^{2}$ is closely related to their Pearson correlation $\left(D^{2} /\right.$ number of libraries $\left.=2(1-r)\right)$ and the distance between columns (libraries) is a measure of the relative tag numbers ${ }^{14}{ }^{22}$. Finally, columns and rows were clustered by Ward's method using the Statistica ${ }^{\mathrm{TM}}$ software package (StatSoft Benelux BV, Groningen, The Netherlands). Sorting in two dimensions reorganized these data, which generates an expression matrix as shown in FIGURE 1, in which each cell was assigned a color corresponding to its value.

\section{Northern Blot hybridization}

Northern blot analysis was essentially carried out as described previously ${ }^{12}$. Labeling with $\left[\alpha-{ }^{32} \mathrm{P}\right]$ deoxycytidine triphosphate was carried out with the Oligolabeling Kit (Pharmacia Biotech, Uppsala, Sweden) according to the manufacturer's directions.

\section{Immunohistochemistry}

Immunohistochemistry was performed on epidermal sheets of normal skin and actinic keratosis obtained as indicated above. Tissues were fixed in formalin, embedded in paraffin and processed for staining as described previously ${ }^{23}$. 


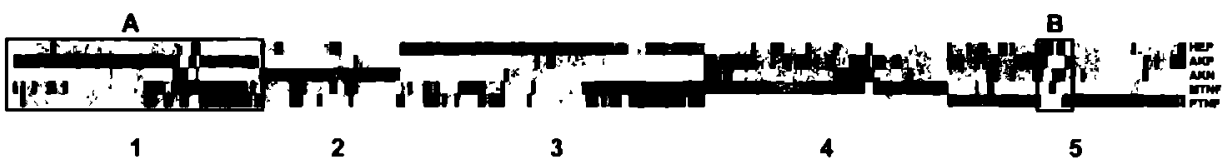

Figure 1 Visualization of the expression level matrix consisting of the 300 most informative transcripts. From top to bottom the five different libraries are represented as follows: normal human epidermis (HEP), epidermis from actinic keratosis rumor materıal (AKP), normal epidermis from the actinic keratosis patient (AKN), resting cultured keratınocyes (MTNF) and cultured keratinocytes treated with tumor necrosis factor alpha (PTNF). Clusters of co-regulated genes that are clearly distinguishable are numbered from 1 to 5. Two clusters that differentuate gene expression in actinıc keratosis lesions from the other samples are marked with $A$ and B. Gene expression levels are indicared usıng a color index ; ranging from high (red) to low (dark blue). See last pages for colour image of this figure.

\section{Construction of SAGE libraries}

Three punch biopsies were taken from each tissue and treated with dispase, to generate epidermal sheets without admixture of components from the underlying dermis. Histological examination revealed that clear separation of dermis and epidermis was routinely obtained both for normal epidermis and for skin tumors (actinic keratosis) which grow superficially and do not penetrate the epidermis very deeply. Epidermal sheets were pooled and subjected to RNA isolation. To exclude the possibility that one of the epidermal sub-populations was damaged during the isolation, and would therefore be subject to mRNA degradation we examined the ratio berween mRNA levels in basal en suprabasal cells. Using cytokeratin 5 and cytokerarin 10, restricted respectively to basal layer and suprabasal layers, we calculated the ratio of $\mathrm{K} 5$ over $\mathrm{K} 10$. As the ratio of $\mathrm{K} 5$ over $\mathrm{K} 10$ in either total biopsy and epidermal sheet were similar (data not shown) we concluded that no essential information is lost during the isolation procedure. Using this procedure in combination with the MicroSAGE protocol ${ }^{20}$, three SAGE libraries were generated from normal human epidermis, epidermis from an actinic kerarosis lesion and normal epidermis from the same individual. Two libraries obtained from cultured keratinocytes ${ }^{7}$ were generated using the original SAGE procedure as previously described ${ }^{6}$.

\section{General results and statistics}

TABLE 1 summarizes the number of tags sequenced in the five combined libraries and the frequencies of occurrence. A large proportion of the tags was found only once and are therefore not informative for quantitarive purposes. Clearly, far more tags need to be sequenced to obtain a true transcriptome as was done for yeast ${ }^{24}$. A list of all tags found is available at our web site (http://dermatology.azn.nl/). In the two libraries of normal human epidermis we found that over 12,500 genes were expressed. As recent estimates of the total number of genes in the human genome are in the order of 30,000 to $40,00025,26$, our data demonstrate that epidermal keratinocytes have the potential to express at least $35 \%$ of the human genome.

\section{Cluster analysis}

To use the full potential of the data, we used cluster analysis to identify sets of genes that 
All libraries

Frequency

$>20$

519

24

1

Total

$$
\begin{array}{r}
\text { Genes } \\
332 \\
1,135 \\
4,226 \\
17,906 \\
23,599
\end{array}
$$

$\%$
14
48
179
759
1000
$\%$
372
159
172
297
1000

behave sımılarly across the different librarıes In this study frequency distributions from the five individual SAGE librarıes were organized in an expression level matrix, in which each row corresponds to a single transcript and each column represents an individual library To efficiently separate, identify and extract useful information the data set was compressed, to focus on a small subset of transcripts Within the data set the majoricy of transcripts is expressed at low levels and may mask the effect of smaller subsets of genes that are relevant After transformation of the final subset of most informative transcripts, cluster analysis was performed on both libraries and transcripts The results are visualızed in FIGURE 1, using a color index (ranging from high (red) to low (dark blue) gene expression levels) Clustering of the individual SAGE libraries separates the two in vitro libraries from the in vivo ones (data not shown) The libraries obtained from cultured cells are clearly separated from the epidermal libraries by the gene clusters marked with 4 and 5 Looking at the overall picture, cluster analysis shows several compact clusters of co-regulated genes within the different libraries (indicated by the sidebars with corresponding number) Visual representation of the cluster analysis also reveals two clearly discernible clusters (A and B) that differentiate gene expression in actinic keratosis lesions from other samples Cluster A contains genes that are expressed at high levels only in the tumor tussue Cluster B contans genes that are highly expressed in the tumor and in the cultured cells, but have low expression levels in the two libraries from normal epidermis These two clusters are potentially interesting because the genes contained in it can be of biological or diagnostic/prognostic significance for this particular type of tumor In FIGURE 2 we have enlarged the two clusters and their corresponding tags were associated with either the GenBank accession numbers or -in case no accession number was avalable- with the UnıGene cluster identification Usıng GenBank accession numbers, several tags could be unequivocally identıfied, stıll leaving a considerable set of tags as unknown Because many of these tags refer to ESTs or uncertan UniGene clusters, these tags were left out of the analysis

\section{Verification and validation of gene expression data}

Because SAGE is a complex technique that results in large data sets derived from a small number of samples, we wanted to verify two things before we proceeded with further analysis and biological interpretation First, we wanted to investigate if the observed differences were not artificial, and secondly we wanted to establish if the findings derived from the pooled tumors obtained from one patient could be extrapolated more generally to this type of tumor Therefore, we examined the expression of three genes identified in clusters $A$ and $B$ from figure 1 , that showed an increased expression in the tumor psoriasis-associated fatty acid binding protein (PA-FABP), also known as epidermal fatty acid binding protein (E-FABP), migration inhibitory factor-related protein 8 (MRP-8) and psoriasin To this end, we investigated these genes at the mRNA and protein level in tissue 


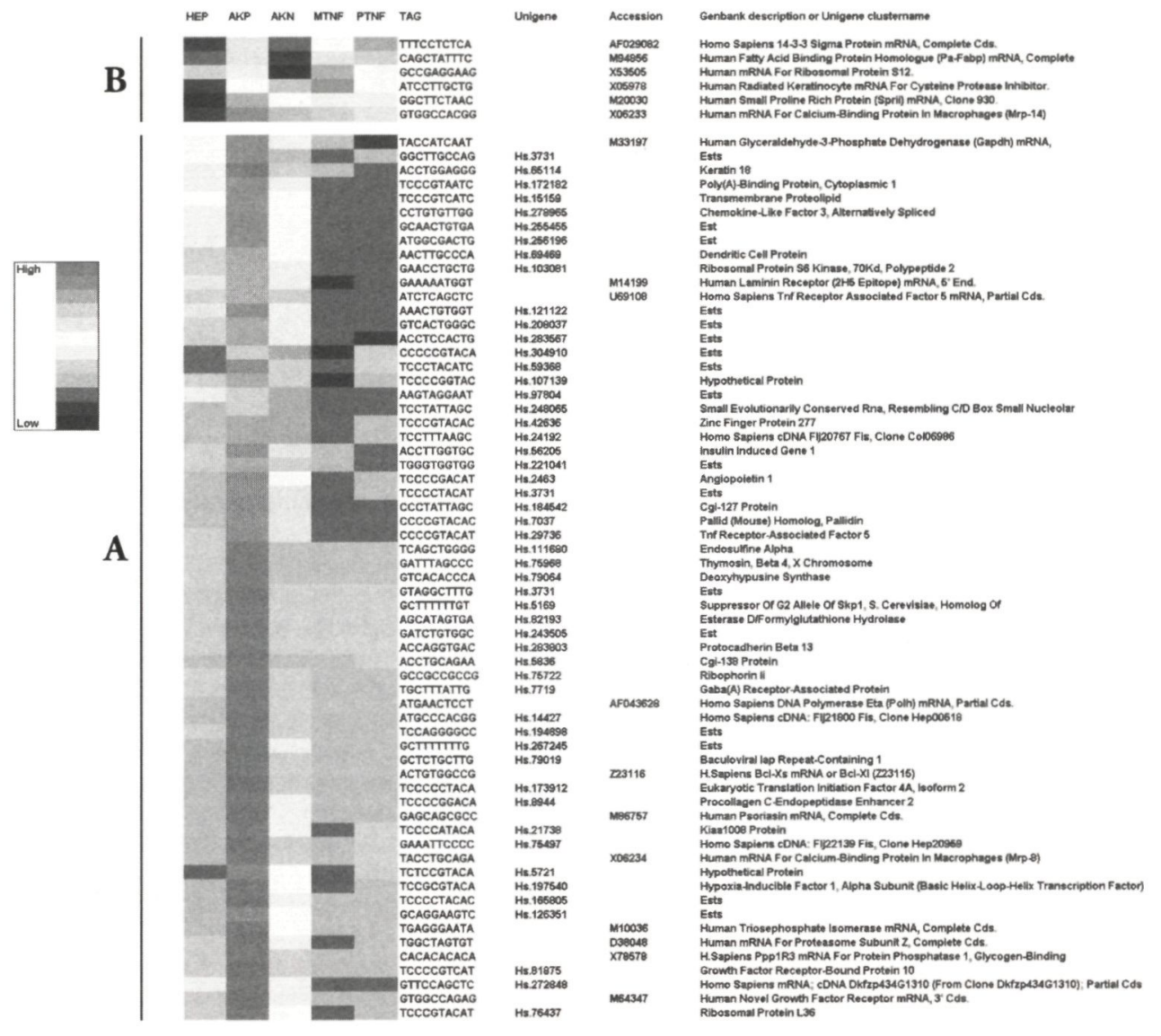

Homo Sapiens 1433 Sigma Protein mRNA, Complete Cds

Est Dendritic Cell Protein Hyothetical Protein Homo Sapiens CDNA Fll20767 Fis, Clone Col069e0 Anglopoletin 1

Cgl-127 Protein Palld pouse) Homolog. Palt din Thr Receptor-Associated Factor ( Dexylypusine Symthase

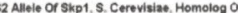
Caborill

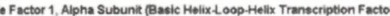
Nomat Protein L36

FIGURE 2 Tags and corresponding genes from cluster A and B (FIGURE 1). These clusters contain tags that are upregulated in tumor tissue compared to normal epidermis. From left to right the libraries are indicated as follows: normal human epidermis (HEP), epidermis from actinic keratosis tumor material (AKP), normal epidermis from the actinic keratosis patient (AKN), resting cultured keratinocytes (MTNF) and cultured keratinocytes treated with tumor necrosis factor alpha (PTNF). Corresponding tags were associated with either the GenBank accession numbers or the UniGene cluster identifications and their gene description. See last pages for colour image of this figure.

samples from 4 different patients, one of which was used to construct the SAGE libraries. In addition, normal epidermis from 3 healthy volunteers was included. Using northern blot analysis (FIGURE 3A) it is shown that the difference in expression levels of these genes, as found in SAGE analysis of one patient, can also be demonstrated in tumors from 4 patients, using an independent technique. We extended these control experiments at the protein level by immuno-histochemical examination of MRP-8 and PA-FABP (FIGURE 3B), which also confirmed the observed differences.

Our analyses also revealed the expression of a number of tags not associated with a GenBank/UniGene accession number or not previously known to be expressed in human 


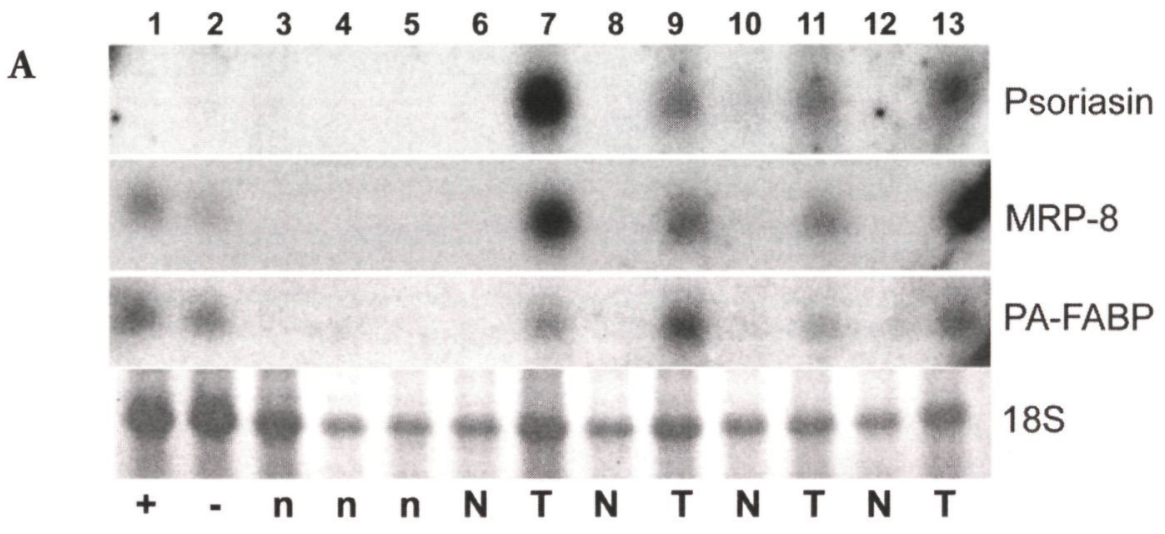

B

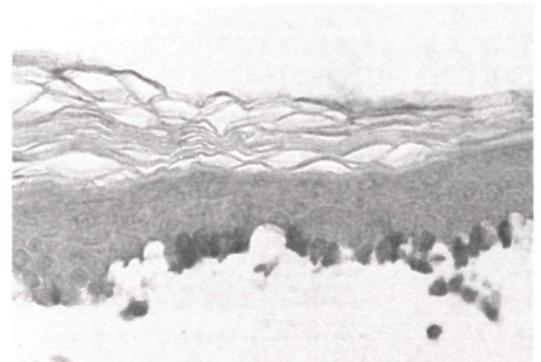

A
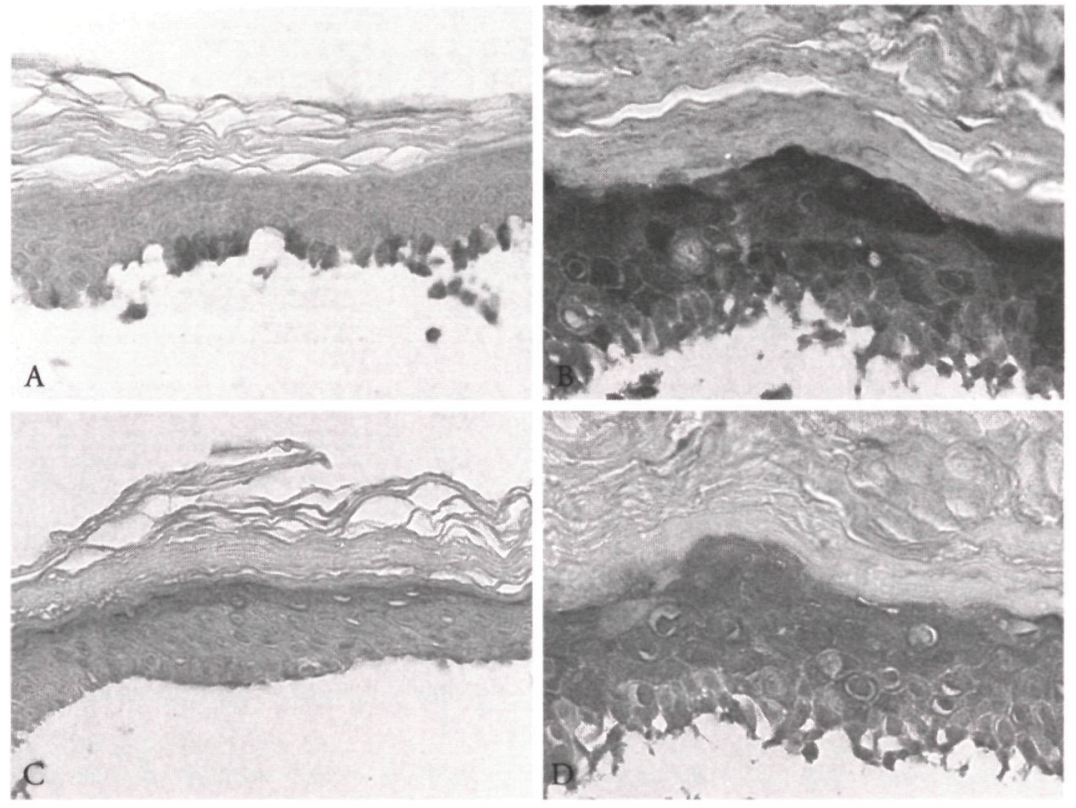

FIGURE 3 A) Confirmation of SAGE data by northern blot analysis. The expression of three genes identified in clusters A and B from Figure 1 was examined: PA-FABP, MRP-8 and psoriasin. Biopsy material from 4 different patients (N=normal; $T=t$ tumor; lanes 6-13) including the patient from which the SAGE library was constructed (lanes 6 and 7) was compared against normal (n) epidermis (lanes 3-5). Lanes 1 and 2: TNF-a stimulated cultured keratinocytes (+) and resting keratinocytes (-). To verify that the changes in expression levels were not due to unequal loading of the samples we included the $18 \mathrm{~S}$ band as a control. In all tumors examined the upregulation of these genes could be confirmed. B) Confirmation of SAGE data by immunohistochemistry. Protein expression levels of MRP-8 (panel A and B) and E-FABP (panel C and D) were examined in normal human skin (panel A and C) and in actinic keratosis lesions (panel B and D). MRP-8 is not expressed in normal epidermis but is found in the suprabasal compartment of the tumor. The staining of the basal cells is due to melanin. E-FABP is normally restricted to the stratum granulosum but in the tumor it is expressed throughout the suprabasal compartment. See last pages for colour image of this figure. 

gene symbol (HUGO) used as reference for PubGene network searches

\section{Tag}

$\begin{array}{lll}\text { ACTGTGGCCG } & \text { BCL2L1 } & \text { Z23116 } \\ \text { CACACACACA } & \text { PPP1R3 } & \text { X78578 } \\ \text { GCCGAGGAAG } & \text { RPS12 } & \text { X53505 } \\ \text { TACCTGCAGA } & \text { S100A8 } & \text { X06234 } \\ \text { GTGGCCACGG } & \text { S100A9 } & \text { X06233 } \\ \text { ATCCTTGCTG } & \text { CSTA } & \text { X05978 } \\ \text { ATCTCAGCTC } & \text { TRAF5 } & \text { U69108 } \\ \text { CAGCTATTTC } & \text { FABP5 } & \text { M94856 } \\ \text { GAGCAGCGCC } & \text { S100A7 } & \text { M } 86757 \\ \text { GTGGCCAGAG } & \text { FGFR3 } & \text { M64347 } \\ \text { TACCATCAAT } & \text { GAPD } & \mathrm{M} 33197 \\ \text { GGCTTCTAAC } & \text { SPRR2A } & \mathrm{M} 20030 \\ \text { GAAAAATGGT } & \text { LAMR1 } & \mathrm{M} 14199 \\ \text { TGAGGGAATA } & \text { TPI1 } & \mathrm{M} 10036 \\ \text { TGGCTAGTGT } & \text { PSMB7 } & \text { D 38048 } \\ \text { ATGAACTCCT } & \text { POLQ } & \text { AF052573 } \\ \text { TTTCCTCTCA } & \text { SFN } & \text { AF029082 }\end{array}$

Gene symbol Accession no. GenBank description

Bcl-Xs or Bcl-Xl (Z23115)

Ppp1R3

Ribosomal Protein S12.

Calcium-Binding Protein In Macrophages (Mrp-8)

Calcium-Binding Protein In Macrophages (Mrp-14)

Cysteine Protease Inhibitor.

Tnf Receptor Associated Factor 5

Fatty Acid Binding Protein Homologue (Pa-Fabp)

Psoriasin

Novel Growth Factor Receptor

Glyceraldehyde-3-Phosphate Dehydrogenase (Gapdh)

Small Proline Rich Protein (Sprii)

Laminin Receptor (2H5 Epitope)

Triosephosphate Isomerase

Proteasome Subunit Z

DNA polymerase theta (POLQ)

14-3-3 Sigma Protein

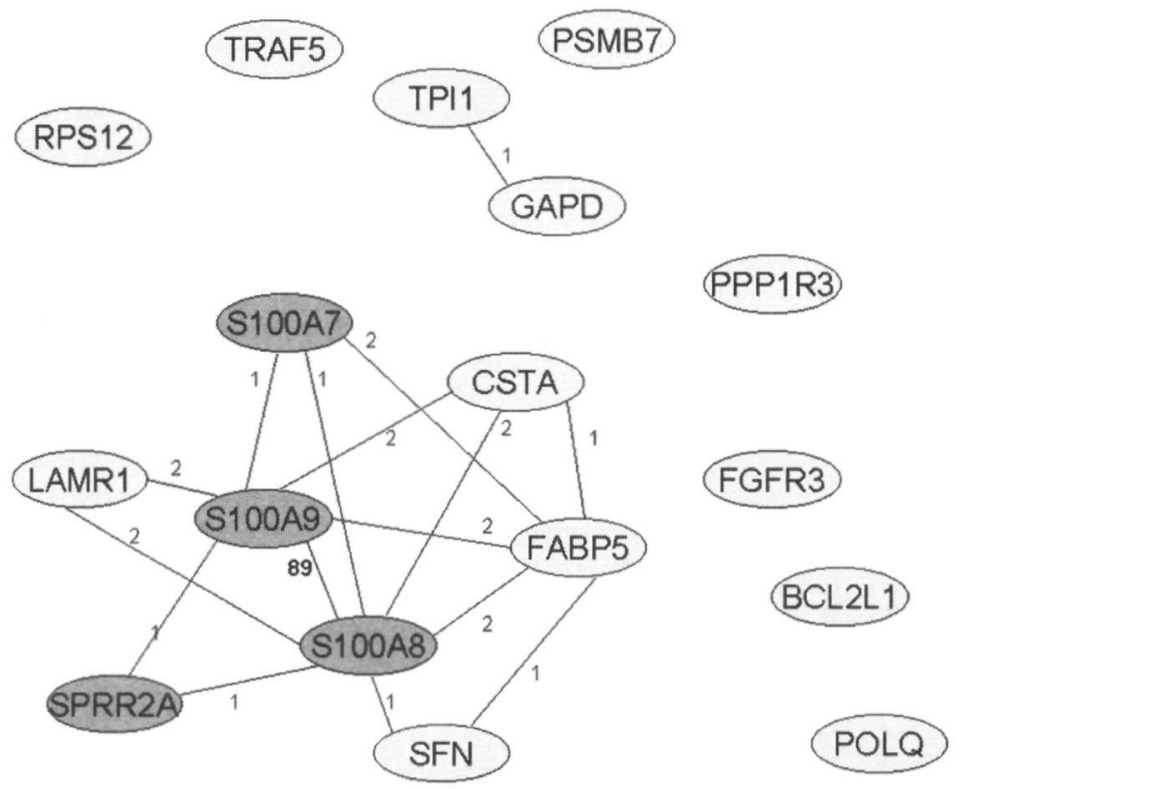

FIGURE 4 Literature networks of reliable genes found upregulated in actinic keratosis (see TABLE 2). Gene symbols were submitted to identify co-expressed groups of genes associated in the literature. Lines connect genes that have cooccurred in one or more articles. Annotations reflecting the number of literature co-citations are indicated. Gene indicated in dark gray are located on chromosome 1q21. 
kerarinocytes, such as polymerase theta ${ }^{27}$ which was found to be upregulated in actinic keratosis (see FIGURE 2). The presence of polymerase theta was confirmed using RT-PCR and sequence analysis (data not shown). A number of unidentified tags were examined to identify the corresponding cDNA via a recently published protocol that uses the tag sequence and modified oligo dT as PCR primers ${ }^{28}$. Identification of the corresponding genes is beyond the scope of this paper and will be published separately.

\section{Pathway and profile analysis by automated literature search}

The set of reliable genes (clear identification in GenBank, TABLE 2) which was found to be overexpressed in the tumor was subjected to conventional PubMed searches to look for known expression patterns and putative functions of these molecules. In addition we used the PubGene tool that was recently developed for automated literature-to-gene searches ${ }^{29}$. When this set of genes, with their corresponding gene symbol according to the HUGO Nomenclature Committee, was subjected to the PubGene Subset network tool, a literature network of 8 of the upregulared genes based on co-occurrence was obtained as shown in FIGURE 4. Interestingly, within this cluster 4 of the identified genes are located in a region on chromosome $1 \mathrm{q} 21$, which contains a known differentiation cluster ${ }^{30,31}$. 
Cellular changes within the transition of normal skin to a (pre)malignant state as exemplified in the skon tumor studied here, may involve only a small subset of genes. Relevant signals associated with this process may be overwhelmed by the noise of irrelevant information. The information content of gene expression levels across the samples can be low in two ways. In our SAGE libraries many genes showed only low expression levels across the samples (1-3 tags); obviously, these levels of expression are insufficient to allow statistically reliable evaluation. Alternatively, expression levels for a given gene can be high across the samples, but are not informative because of the lack of difference. To examine the data generated in the SAGE libraries we first reduced the number of genes to be analyzed, by compressing the data set and selecting the $\mathbf{3 0 0}$ most informative tags for further study. These tags were used to cluster the samples and the genes. A similar approach was recently described to analyze micro-array data from which stable gene and sample clusters were obtained using coupled two-way cluster (CTWC) analysis ${ }^{15}$. In a recent publication using SAGE different colorectal and pancreatic carcinomas were compared and cluster analysis revealed a cluster of invasion-specific genes ${ }^{32}$. Due to the complexity and amount of effort associated with the generation of SAGE libraries, it is obvious that only small numbers of samples (libraries) can be analyzed. Therefore, it is mandatory that whenever genes are detected that are differentially expressed, independent methods for confirmation on larger sample numbers are required to ascertain if the data can be extrapolated more generally.

To examine the data generated in the SAGE libraries we first reduced the number of genes to be analyzed, by sorting the tags for information content. The $\mathbf{3 0 0}$ most informative tags were used for further study. Figure 1 shows a number of tag-clusters that can be easily recognized by visual inspection. The two clusters $A$ and $B$ that we have examined more closely were selected because they contain transcripts that were strongly upregulated in the tumor compared to normal human epidermis and compared to epidermis from the same patient. These genes appear to be tumor-specific in a sense that they are not found at appreciable levels in the normal tissue. As such, they can either be causally involved in the process of carcinogenesis, or they are part of an alternative program of differentiation that is switched on by acquired alterations in genes that act as molecular switches. Clearly, identification of these genes would allow us to study initiating events in carcinogenesis. In the case of the type of tumor studied here (actinic keratosis in kidney transplant patients), both vırus infectıons and non-infectious mechanısms such as UV-irradiation have been implicated as a triggering event. The continuous immuno-compromised status of these patients would favor development of tumors that would otherwise be cleared by the immune system. The two clusters of tags that are upregulated in the tumor contain a number of transcripts that cannot be assigned unequivocally to a UniGene cluster or a defined mRNA in the databases. However, several of the tags that could be identified with certainry can be associated with the process of cancer development on the basis of their presumed function or expression pattern reported in the literature, such as MRP8 and MRP14 ${ }^{33}$, PA-FABP ${ }^{4}$, psoriasin ${ }^{35}{ }^{36}, 14-3-3$-sigma ${ }^{17}{ }^{18}$, PPPIR3 ${ }^{39}{ }^{40}$, polymerase theta ${ }^{27}$ and $\mathrm{Bcl}-\mathrm{X}^{41}{ }^{42}$. Interestingly, at least five of these genes are known to be strongly upregulated in psoriasis, a benign hyperproliferative skin condition characterized by grossly abnormal differentiation. However, in psoriasis the expression of this phenotype is reversible as the disease is presumably triggered by environmental stimuli (activated T-cells, infection, stress), whereas in actınic keratosis this phenotype is permanently switched on. We would hypothesize that genes that act as a (reversible) molecular switch in psortasis could be irreversibly activated by genetic alterations in premalignant epidermis leading to actinic keratosis and 
eventually to SCC. The on-switch of a hyperproliferative phenotype, in combination with mutations in tumor suppressor genes or DNA-repair genes would effectively favor tumor promotion and further acquisition of genetic alterations leading to tumor progression and malignancy. In this perspective p 53 could be considered as a relevant tumor suppressor gene for skin tumors with a squamous differentiation phenotype, as mutations in p 53 have been found in early premalignant skin lesions and even in normal skin, and are implicated in the formation of $\mathrm{SCC}^{24}$.

Two-way cluster analysis of these 300 informative tags separated the cultured cells from the biopsies. Remarkably, the expression profile from the 'normal' epidermis of the patient was more similar to the epidermis of the tumor tissue than to normal epidermis from a healthy volunteer. The apparent difference between the normal skin from the healthy individual and the patient can be caused by the fact that the skin of the patient was from a sunexposed area, whereas the skin from the healthy individual was from a non sun-exposed area. Alternatively, the immunosuppressive therapy that kidney transplant patients undergo could also affect epidermal gene expression in the normal skin and in the tumor, resulting in deviation from skin of non-immunosuppressed individuals which causes them to be similar in the cluster analysis. Recently it has been shown that immunosuppressive therapy (e.g. cyclosporin) can cause tumor progression and malignancy independent of host immunity ${ }^{43}$. Our findings lend support for this contention, but clearly this needs further investigation in a larger series of patients.

To exploit the full potential of large-scale expression data, not only appropriate statistical tools need to be available but also tools that allow biological interpretation of the data are required. Sets of co-regulated genes identified in SAGE or micro-array experiments should be analyzed in the available biomedical literature or databases for common properties with respect to tissue/cell type expression patterns and regulatory mechanisms such as similarities in promoter regions, signaling cascades, response to drugs etc. Automated literature and database search tools would be extremely useful in this. A recently developed webbased interface such as PubGene ${ }^{29}$ is a first step in this direction as demonstrated in FigURE 5 . Although limited by inconsistencies of used gene symbols, synonyms and abbreviations in the biomedical literature it provides us with a powerful tool to identify networks of genes that are possibly related by their function or expression patterns. In addition to the reference network, chromosomal localization of these genes confirms the idea that they are likely to be co-regulared because four of them (S100A7, S100A8, S100A9, SPRR2A) are located in a gene cluster on chromosome lq21. Manual lirerature searches using PubMed resulted in the following literature references in which combinations of the previously mentioned genes are described ${ }^{30} 31{ }^{44} 46$, supporting the idea that these genes are coexpressed. In the special case of S100A8 and S100A9 we retrieved 112 literature references in which both genes were described. The number of reference hits is not completely surprising because S100A8 and S100A9 form a heterodimeric complex resulting in a relatively high number of literature references.

How does this type of analysis applied to SAGE data compare with analysis of micro-array data? Obviously, the throughput of micro-array technology is higher than that of SAGE and it is anticipated that micro-arrays will utimately be the preferred methodology. However, we and others have now shown that it is possible to obtain medium-sized SAGE libraries from very small tissue samples (105-106 cells) yielding $100 \mathrm{ng}$ of mRNA or less which is still below the sensitivity of micro-array hybridization ${ }^{20}$. An additional advantage is that SAGE does not select for known genes but potentially can discover new genes, whereas with cDNA micro-arrays only the genes present on the array are addressed. 
Finally, data from a number of SAGE libraries are now publicly available and could be used for the type of analyses described here. Clearly, use and further development of cluster analysis algorithms ${ }^{15}$ and automated literature search tools ${ }^{29}{ }^{47}$ will generate powerful tools for large scale expression data analysis.

\section{Acknowledgements}

We gratefully thank Dr. K.W. Kinzler, Johns Hopkins Oncology Center, Baltimore, MD, for advise and providing the SAGE protocol and the SAGE Software package, and Dr. P. Madsen, Department of Medical Biochemistry, University of Aarhus, Denmark. for providing us with cDNA probes for respectively psoriasin, PA-FABP, and the antibody raised against MRP-8 (Madsen). Finally, we want to thank Dr. G. Siegenthaler, Department of Dermatology, Hôpital Cantonal Univ., Geneva, Switzerland for providing the antibody raised against E-FABP, and J. Smit and Dr. E.M.G.J. de Jong, Department of Dermatology, University Medical Center St Radboud, Nijmegen, The Netherlands for providing the patient material and useful discussions.

Note. The libraries described in this Chaprer have been deposired at the Gene Expression Omnibus (hrp //www.ncbı.nlm.nih gov/geo/) under the following accession numbers GSM1 $121 \cdot$ SAGE library derived from culcured kerannocytes, GSM1122. SAGE library derıved from TNF- $\alpha$ stımulated keranonocytes, GSM1123 SAGE library derived from human epidermis; GSMII24 SAGE library denved from unaffected epidermis of acunic keratosis patient, GSM1125 SAGE hbrary derived from affected epidermus of acunic keratosis patient The libraries are collectively accessible under sample series accession number GSE31. All libraries can also be accessed through the SAGE websıte at http $/ /$ www ncbı.nlm nih gov/SAGE/ 
1 Rees J Genetic alterations in non-melanoma skan cancer.

J Invest Dermatol 1994:103(6)·747-750

2. Nelson MA, Einspahr JG, Aberts DS, Balfour CA, Wymer JA, Welch $K L$, et al Analysis of the $\mathrm{p} 53$ gene in human precancerous actinic keratosis lesions and squamous cell cancers Cancer Letr 1994,85(1):23-29.

3. Jonason AS, Kunala S, Price GJ, Restıfo RJ, Spınellı HM, Persıng JA, et al Frequent clones of p53-mutated keratinocytes in normal human skun. Proc Nat Aad So U S A 1996;93(24)·14025-14029

4. Ziegler A, Jonason AS, Leffell DJ, Simon JA, Sharma HW, Kmmelman J, et al Sunburn and p53 in the onset of sken cancer.

Nature 1994;372(6508):773-776.

5 Popp S, Waltering S, Holrgreve-Grez $H$, Jauch $A$, Proby C, Leigh IM, ex al Genetic characterization of a human skun carcınoma progression modelfrom primary tumor to metastasts. J Invest Dermatol 2000;115(6) 1095-1103

6. Velculescu VE, Zhang L, Vogelstein B, Kinzler KW Serial analysis of gene expression Science 1995;270(5235):484-487.

7 Jansen BJH, Van Russen F, De Jongh G, Zeeuwen PLJM, Schalkwıjk J. Serıal Analysıs of Gene Expression in Differentiated Cultures of Human Epıdermal Keratinocyres. J Invest Dermatol 2001;116(1) 12-22

8 Colantuonı C, Purcell AE, Bouton CM, Pevsner J. High throughput analysis of gene expression in the human bran.

J Neurosel Res 2000:59(1) 1-10

9. El Meanawy MA, Schelling JR, Pozuelo F, Churpek MM, Ficker EK, lyengar $S$, et al Use of serial analysis of gene expression to generace kidney expression lıbraries Am J Physiol Renal Physiol 2000;279(2).F383-F392.

10 Virlon B, Cheval L, Buhler JM, Billon E, Doucet A, Elalouf JM. Serial microanalysis of renal transcriptomes Proc Natl Acad Sci USA 1999;96(26) 15286-15291

11 St Croux B, Rago C. Velculescu V, Traverso G, Romans KE, Montgomery $E$, et al Genes expressed in human rumor endorhelium Science 2000;289(5482):1197-1202.
12. Yamamoto M, Wakatsuku T, Hada A, Ryo A Use of serial analysis of gene expression (SAGE) technology J Immunol Methods 2001;250(1-2):45-66.

13 Zhou W, Sokoll LJ, Bruzek DJ, Zhang L, Velculescu VE, Goldın SB, et al Idenrifyıng markers for pancreatic cancer by gene expression analysıs Cancer Epıdemıol Bıomarkers Prev $1998 ; 7(2) 109-112$

14 Alon U, Barkan N, Notterman DA, Gish K, Ybarra S, Mack D, et al Broad patterns of gene expression revealed by clustering analysis of tumor and normal colon tussues probed by oligonucleotide arrays. Proc Natl Acad Sa U S A 1999,96(12):6745-6750.

15 Gerz G, Levine E, Domany E. Coupled rwo-way clustering analysis of gene microarray dara. Proc Natl Acad Sci U S A 2000;97(22).12079-12084.

16 Hartevelt MM, Bavınck JN, Kootte AM, Vermeer BJ, Vandenbroucke JP. Incidence of skun cancer after renal transplantation in The Netherlands. Transplantation 1990;49(3):506-509.

17. Glover MT, Niranjan N, Kwan JT, Leigh IM Non-melanoma skun cancer in renal transplant recipients: the extent of the problem and a strategy for management Br J Plast Surg 1994,47(2) $\cdot 86-89$

18 Birkeland SA, Srorm HH, Lamm LU, Barlow L, Blohme I, Forsberg B, et al. Cancer risk after renal transplantation in the Nordic countries, 1964-1986. Int J Cancer 1995;60(2) 183-189.

19. Van Ruissen F, de Jongh GJ, Zeeuwen PL, van Erp PE, Madsen P, Schalkwıjk J Induction of normal and psortatic phenorypes in submerged keratınocyre cultures.

J Cell Physiol 1996;168(2) $442-452$

20. Datson NA, Perk-de Jong J, van den Berg MP, de Kloet ER, Vreugdenhil E MicroSAGE a modified procedure for serial analysis of gene expression in limited amounts of tissue. Nucleic Acıds Res 1999,27(5) 1300-1307

21 Kenzelmann M, Muhlemann K Substantially enhanced cloning efficiency of SAGE (Serial Analysis of Gene Expression) by adding a heating step to the original protocol.

Nucleic Acids Res 1999;27(3)・917-918 
22 Hartigan JA. Clusterıng algorıthms.

New York: Wiley; 1975.

23 Van Russen F, Le M, Carroll JM, van der Valk PG, Schalkwıjk J Differential effects of derergents on keratınocyre gene expression. J Invest Dermarol 1998;1 10(4):358-363.

24 Velculescu VE, Zhang L, Zhou W, Vogelstein J, Basra MA, Bassett DE, Jr., et al. Characrerization of the yeast transcriptome Cell 1997;88(2).243-251.

25 Lander ES, Linton LM, Birren B, Nusbaum C, Zody MC, Baldwin J, et al. Initıal sequencing and analysis of the human genome Nature 2001;409(6822):860-921.

26 Venter JC, Adams MD, Myers EW, Lı PW, Mural RJ, Sutton GG, et al. The sequence of the human genome Science 2001,291(5507):1304-1351.

27 Johnson RE, Prakcash S, Prakash L The human DINB1 gene encodes the DNA polymerase Polcheta. Proc Natl Acad Scı U S A 2000;97(8):3838-3843

28 Chen JJ, Rowley JD, Wang SM. Generation of longer cDNA fragments from serial analysis of gene expression tags for gene identification Proc Nacl Acad Sci U S A 2000;97(1).349-353.

29 Jenssen TK, Laegreıd A, Komorowsk J, Hovig E A literature network of hurnan genes for high-throughput analysis of gene expression. Nat Gener 2001;28(1):21-28.

30 Marenholz I, Volz A, Ziegler A, Davies A, Ragoussis I, Korge BP, et al. Generic analysis of the epidermal differentiation complex (EDC) on human chromosome $1 \mathrm{q} 21$ : chromosomal orientation, new markers, and a 6-Mb YAC conesg Genomics 1996;37(3)·295-302

31 Mischke D, Korge BP, Marenholz I, Volz A, Ziegler A. Genes encoding structural proteins of epidermal cormification and $S 100$ calcium-bınding proteins form a gene complex ("epidermal differentiation complex") on human chromosome lq21

J Invest Dermatol 1996,106(5)·989-992

32 Ryu B, Jones J, Hollıngsworth MA, Hruban RH, Kern SE. Invasion-specific genes in malıgnancy. serial analysis of gene expression comparisons of primary and passaged cancers.

Cancer Res 2001;61(5):1833-1838.
33. Stulık J, Kouplova K, Osterreicher J, Knizek J, Macela A, Bures J, et al Protein abundance alterations in matched sets of macroscopically normal colon mucosa and colorecral carcinoma Electrophoresıs 1999;20(18)·3638-3646

34 Jing C, Beesley C, Foster CS, Rudland PS, Fuji $\mathrm{H}$, Ono $\mathrm{T}$, et al Identification of the messenger RNA for human cutaneous fatty acid- binding prorein as a metastasis inducer. Cancer Res 2000;60(9):2390-2398

35 Al Haddad S, Zhang Z, Leygue E, Snell L, Huang A, Niu Y, et al Psoriasın (S100A7) expression and invasive breast cancer. Am J Parhol 1999;155(6)·2057-2066

36 Wasson PH, Leygue ER, Murphy LC Psoriasın (S100A7) Int J Bıochem Cell Bıol 1998;30(5):567-571.

37 Vercoutcer-Edouart AS, Lemone J, Le B, X, Louis H, Boilly B, Nurcombe V, et al. Proteomic analysis reveals that 14-3-3sigma is down-regulared in human breast cancer cells Cancer Res 2001;61(1):76-80

38 Suzukı H, Iroh F, Toyota M, Kıkuchı T, Kakuuchı H, Imas K. Inactivation of the 14-3-3 sigma gene is associated with $5^{\prime} \mathrm{CpG}$ island hypermethylation in human cancers. Cancer Res 2000;60(16)·4353-4357.

39. Takakura S, Kohno T, Shımızu K, Ohwada S, Okamoto A, Yokota J Somatic mutations and genetic polymorphisms of the PPPIR3 gene in patients with several types of cancers Oncogene 2000;19(6) $\cdot 836-840$

40 Kohno T, Takakura S, Yarnada T, Okamoto A, Tanaka T, Yokota J. Alterarions of the PPP1R3 gene in human cancer Cancer Res 1999;59(17).4170-4174.

41. Kondo S, Shınomura Y, Kanayama S, Higashimoto Y, Mıyagawa JI, Mınamı T, et al Over-expression of $b c l-x \perp$ gene in human gastric adenomas and carcinomas.

Int J Cancer 1996;68(6)·727-730.

42 Leiter U, Schmid RM, Kaskel P, Peter RU, Krahn G Antiapoptotic bcl-2 and bel-xL in advanced malıgnant melanoma. Arch Dermatol Res 2000,292(5).225-232.

43 Hojo M, Morımoro T, Maluccio M, Asano T, Morımoto K, Lagman M, et al Cyclosporıne induces cancer progression by a cell-autonomous mechanism Nature 1999,397(6719)·530-534 
44. Hardas BD, Zhao $X$, Zhang J, Longqing $X$, Stoll S, Elder JT Assigninent of psoriasin to human chromosomal band $1 \mathrm{q} 21 \cdot$ coordinate overexpression of clustered genes in psoriasis J Invest Dermatol 1996; 106(4):753-758

45 Madsen P, Rasmussen HH, Leffers $H$, Honore B, Dejgaard K, Olsen E, et al Molecular cloning, occurrence, and expression of a novel partially secreted protein "psoriasin" that is highly up-regulated in psoriatic sken J Invest Dermatol 1991,97(4).701-712.

46 Madsen P, Rasmussen HH, Leffers $\mathrm{H}$, Honore B, Celis JE Molecular cloning and expression of a novel keratinocyte protein (psorlasis-associared fatty acid-binding protein [PA-FABP]) that is hughly up-regulared in psoriatic skon and thar shares sımilarity to fatty acid-bindıng proteins J Invest Dermatol 1992,99(3).299-305

47. Tanabe L, Scherf U, Smith LH, Lee JK, Hunter $L$, Weinstein JN. MedMiner: an Internet rext-mining tool for biomedical information, with application to gene expression profilıng.

Brorechnıques 1999;27(6) 1 1210-1217 

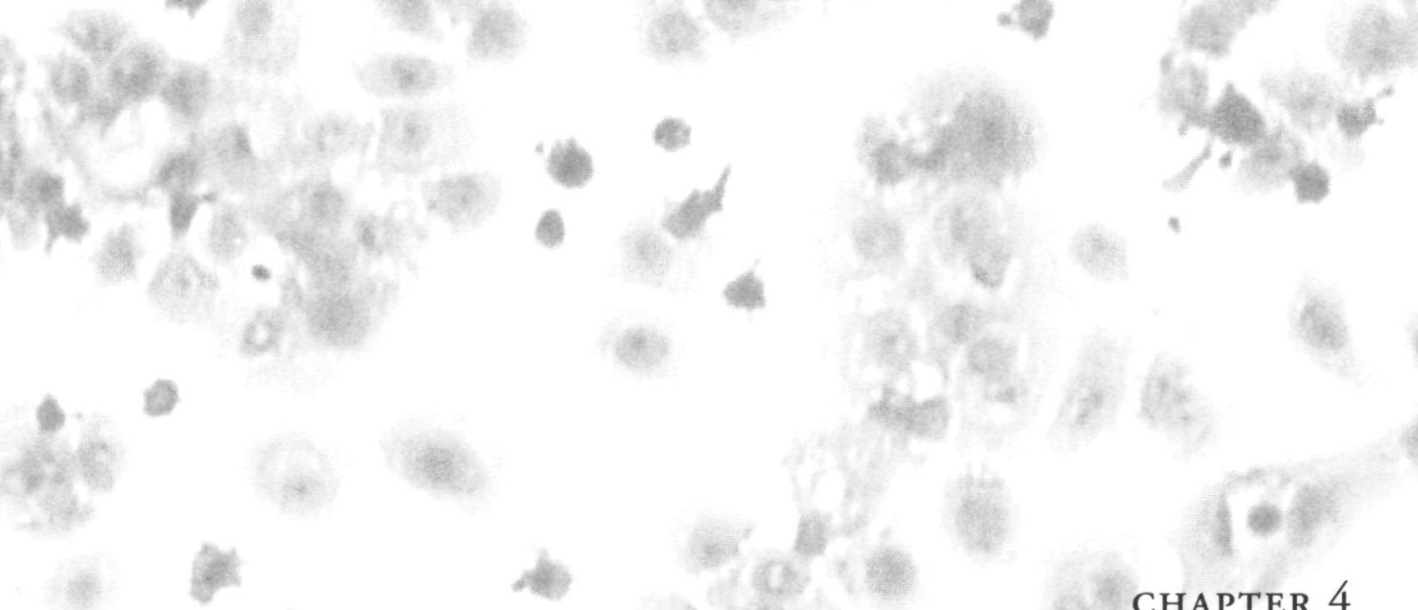

\section{A partial transcriptome of human epidermis}

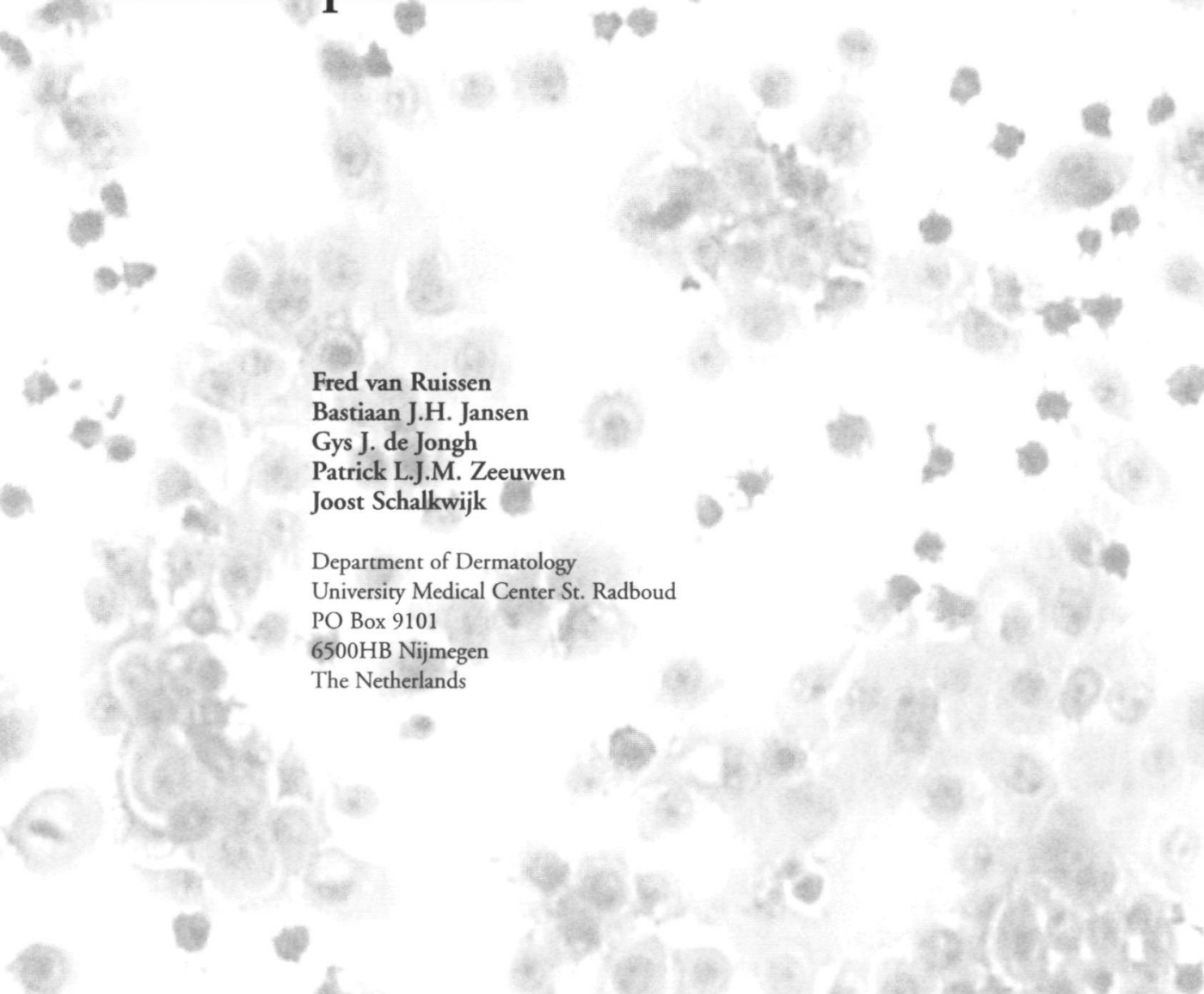

This Chapter has been accepted for publication in Genomics.

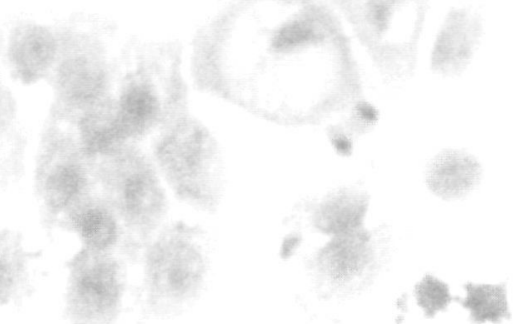



Serial analysis of gene expression (SAGE) is a powerful technique for global expression profiling without prior knowledge of the genes of interest Here we describe SAGE analysis of purıfied keratınocytes derıved from human skın biopsies, resultıng in a partıal transcriptome of human epidermis A library of 15,131 transcript tags was obtained from approximately $3 \times 10^{6}$ epidermal cells In this library more than 7,500 unique tags were identified that putatively correspond to genes expressed by these cells This catalogue contains a large number of genes that were not previously known to be expressed by human epidermis Comparison with the databases of all known human SAGE tags allowed us to identify a number of keratınocyte-specific tags that putatively correspond to hitherto unknown genes Surprisingly, human epidermal keratinocytes in vivo show relatively low expression levels of genes typically associated with epidermal differentiation, whereas the expression levels of housekeeping genes are considerably higher than in cultured keratinocytes This study provides a first step towards a transeriptome of human epidermis and as such harbors a wealth of information to identify genes involved in skin function, and candidate genes for genetic skın disorders 


\section{Introduction}

Within human epidermis, keratınocytes represent the major cell type, providing the organism with a protective barrier agaunst pathogens and chemical or physical stimuli The ughtly coordinated growth and differentiation of keratinocytes, which eventually leads to the unique structure of the epidermis, is controlled by a complex program of gene expression ${ }^{12}$ Within the epidermis, proliferating, undifferentiated cells located in the basal layer undergo a process of terminal differentiation Finally, these cells form the outermost cornified layer or stratum corneum consisting of a covalently cross-linked protein network embedded in lipids In addition, keratınocytes are also engaged in innate and adaptive immunity This is illustrated by the ability of keratinocytes to present antigens ${ }^{b}$, to express various proteins involved in host protection ${ }^{4}$, and to secrete cytokunes and chemokines ${ }^{8}$ Furthermore, keratinocytes can interact with inflammatory cells through their cytokune receptors and adhesion molecules on their plasma membranes, and they can be regulated in both an autocrine and paracrine fashion "Both the innate immune response and the interaction with the immune system during wound healing, skin infections and inflammation, show that keratınocytes serve as an important sıgnaling interface between the external environment and the organism

With improvement and development of new technıques to monitor gene expression patterns, considerable knowledge about gene expression profiles in human keratinocytes in vtvo and in vitro has been obtained, especially on genes encoding cyroskeletal and structural proteins ${ }^{1012}$ Extensive analysis of gene expression in epidermis and cultured keratınocytes on the protein level has been performed previously by the group of Celis " Usıng 2-dimensional polyacrylamide gel electrophoresis (2D-PAGE) and micro-sequencing, hundreds of known and new proteins in epidermis and cultured keratinocytes were identıfied In addition, a partial catalog of secreted proteins in keratınocyte cultures was recently published by Katz \& Taichman ${ }^{14}$ Thus far, no systematic studies on keratinocyte gene expression at the mRNA level have been undertaken, although a considerable amount of data is avalable from randomly sequenced keratinocyte cDNA librarıes ${ }^{15}$ ", differential display polymerase chain reaction ${ }^{1722}$ and cDNA filter arrays ${ }^{21}$

We have previously performed a comprehensive study of keratunocyte gene expression using serial analysıs of gene expression (SAGE) on cultured human keratınocytes The gene expression profiles obtained showed that keratınocytes in vitro express more than 10,000 different genes ${ }^{24}$, although most of them were found at low levels A next step would be to obtain transcriptome information on normal and diseased human skin in vivo, in order to increase our knowledge on normal skın function and to elucidate the molecular basıs of disease The aim of the present study was to describe a partial transcriptome of normal human epidermis, 1 e to make a catalogue of expressed genes at the mRNA level It is, for obvious reasons, difficult to obtain transcriptome information of purified cells derived from solid ussues in vivo First, human skin is a tissue consisting of an epidermal and dermal compartment not allowing direct examination of gene expression in the epidermal compartment Second, only very small amounts of poly-A+ mRNA can be obrained from punch biopsies of human skin The first obstacle could be overcome by enzymatic separation of the dermis and epidermis, using a rapid protocol that minimizes the induction or breakdown of cellular mRNA during the isolation procedure In this way we have generated a homogenous cell populatıon, mainly consistıng of human epıdermal keratınocytes 
We present a detailed description and validation of this separation protocol. To overcome the second obstacle, we used a modification of MicroSAGE ${ }^{25}$ allowing us to start with 100-500 ng poly-A+ mRNA as input material. In principle, this allows us to use one single $4 \mathrm{~mm}$ punch biopsy of human skin as input for the analysis. Because SAGE tag abundances provide a measure of the transcript levels present within the mRNA population, this analysis not only provides qualitative information on new genes expressed in epidermis but also provides quantitative information. As SAGE is not dependent on preexisting databases of expressed genes, it provides an unbiased view of gene expression profiles within mRNA populations.

\section{Cells \& Cell Culture}

Primary human epidermal keratinocytes were obtained as previously described (26). Cells were grown to confluency in $75 \mathrm{~cm}^{2}$ culture flasks under $\mathrm{KGM}\left(0.15 \mathrm{mM} \mathrm{Ca}{ }^{2+}\right.$; BioWhittaker, Verviers, Belgium). Cells were switched to KGM depleted of growth factors for $96 \mathrm{hr}$, a procedure that induces a normal differentiation phenotype in a submerged culture as described extensively before ${ }^{6}{ }^{26}$.

Biopsy material

Punch biopsies ( $4 \mathrm{~mm}$ ) were obtained from normal human skin after surgical removal. All biopsies were taken from volunteers that gave written informed consent. The study protocol was approved by the local medical ethics committee.

\section{Separation of epidermis and dermis}

Punch biopsies were washed with phosphate-buffered saline (PBS) and treated with a proteınase preparation (dispase; $12 \mathrm{mg} / \mathrm{ml}$ in PBS, Roche, The Netherlands) under gentle agitation. To prevent induction of transcription due to the treatment, we performed the separation at $4^{\circ} \mathrm{C}$ in the presence of actinomycin $\mathrm{D}(5 \mu \mathrm{g} / \mathrm{ml})$. A time course experiment demonstrated that treatment with dispase for 4 hours at $4^{\circ} \mathrm{C}$ resulted in efficient separation of the epidermis from the underlying dermıs, and this procedure was used in all experiments. One part of the epidermis and dermis was fixed with $3.8 \%$ formaldehyde solution and embedded in paraffin for histological examination. The other part of the epidermis and a control biopsy were stored in $1 \mathrm{ml} \mathrm{RNAzol} \mathrm{at}-80^{\circ} \mathrm{C}$ until further use.

\section{Serial Analysis of Gene Expression}

Total RNA was isolated from homogenized epidermal sheets and cultured human keratinocytes as described by Jansen et al. ${ }^{24}$. Purified mRNA obtained using the mRNA Capture Kit (Roche, The Netherlands) was used for double stranded cDNA synthesis (cDNA Synthesis System; Roche, The Netherlands). We performed MicroSAGE as described previously with minor modifications ${ }^{25}{ }^{27}$. In contrast to Datson et al. ${ }^{25}$ we used $10 \mu \mathrm{g}$ of total RNA as starting material and performed anchoring and trapping of cDNA in two separate tubes. This procedure also allowed us to perform large-scale PCR amplifications without the need of prior amplification of the 104 bp product. Finally, concatemers were precipitated using $35 \%$ ethanol resulting in a reduction of DNA fragments 
smaller than 200 bp Size-separation of concatemers was performed either on gel or using SizeSep Columns (Pharmacia) with a cutoff around $400 \mathrm{bp}$, yielding a majority of fragments larger than 400 bp Prior to loading on $8 \%$ polyacrylamide gel or on SizeSep columns we heated the concatemers at $65^{\circ} \mathrm{C}$ for 10 min followed by 2 min on ice ". Purified concatemers were subsequently cloned in the SphI site of pZero (Invitrogen Corp., San Diego, CA) and transformed in chemically competent MAX Efficiency DH5 $\alpha$ $E$ colt Competent Cells (Life Technologies Inc., Gauthersburg, MD) by means of heatshock transformation, following the manufacturer's prorocol Clones were selected and colony PCR, sequencing and analysis was performed as described by Jansen et al 20 Corresponding accession numbers were retrieved using the homo sapiens NCBI-GenBank database release $124^{29}$

\section{Northern Blot hybridization}

Northern blot analysis was essentially carried out as described previously ${ }^{26}$ Labeling with $\left[\alpha-{ }^{32} \mathrm{P}\right.$ ] deoxycytıdine truphosphate was carried out with the Oligolabeling Kut (Pharmacia Biotech, Uppsala, Sweden) according to the manufacturer's directions.

\section{Immunohistochemistry}

Immunohistochemistry was performed on epidermal sheets of normal skın obtaned as indicated above Tissues were fixed in formalin, embedded in paraffin and processed for stainıng as described previously ${ }^{30}$

\section{Results and discussion}

\section{Preparation of pure epidermal tissue}

Normal skun tissue was obtaned using a $4 \mathrm{~mm}$ biopsy punch In order to examine gene expression patterns exclusively in the epidermis we developed a protocol that allows rapid separation of the epidermis from the underlyıng dermis under conditions that would minimize de novo expression or degradation of mRNA transcripts during the isolation procedure (see FIGURE 1 for an overview). To assure that during treatment with dispase none of the epidermal cell sub-populations was preferentially lost, the resulting tissue specimen were analyzed histologically. As shown in FIGURE 1, a clear separation of dermis and epidermis was routinely obtauned for normal epidermis To exclude the possibility that one of the epidermal sub-populations was damaged during the isolation, and would therefore be subject to mRNA degradation we examined the ratıo between mRNA levels in basal en suprabasal cells Because cytokeratin 5 (K5) expression is restricted to the basal layer and cytokeratın 10 (K10) expression is restricted to the suprabasal layers, we calculared the ratio of K5 over K10 figure 2 shows a Northern blot that analyzes a complete biopsy consisting of epidermis and dermis, and an epidermal sheet obtained as described in Figure 1 As the ratio of $\mathrm{K} 5$ over $\mathrm{K} 10$ in both lanes is similar we concluded that no essential information is lost during the isolation procedure In addition, we did not detect induction of a known epidermal stress-response marker (skun-derıved antuleukoproteinase, SKALP), a gene that is rapidly induced following epidermal injury (dara not shown) From these findings we concluded that the separation protocol would in principle allow us to take a snapshot of epidermal gene expression without qualitative or quantitative distortion between the time of biopsytakıng and lysis of the cells in denaturing agents to isolate the mRNA 
$4 \mathrm{~mm}$ punch biopsy

of human skin

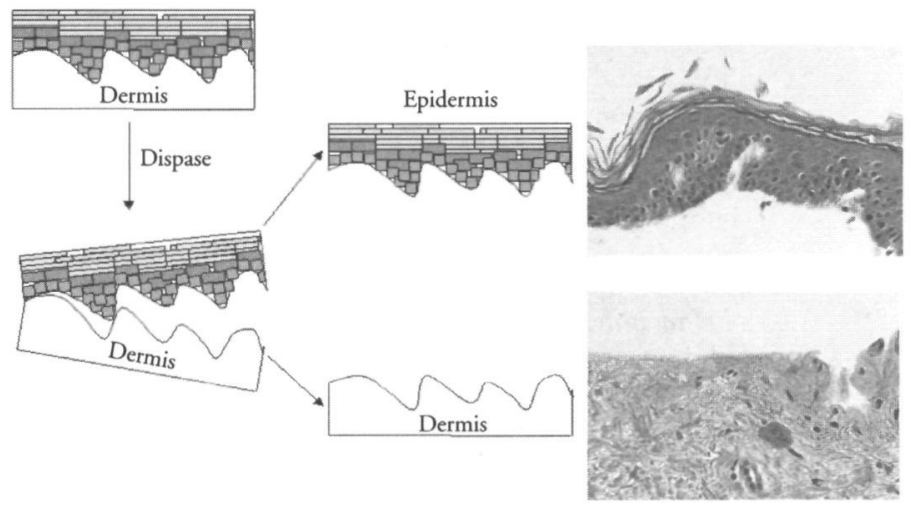

FIGURE 1 Schematic representation of the protocol for purification of epidermal keratinocytes from a 4 mm punch biopsy treatment with dispase followed by mechanical separation of the dermis from the epidermis. On the right side histological sections are shown to visualize the clear separation of dermis from epidermis without disruption of the basal layer of the epidermis.See last pages for colour image of this figure.

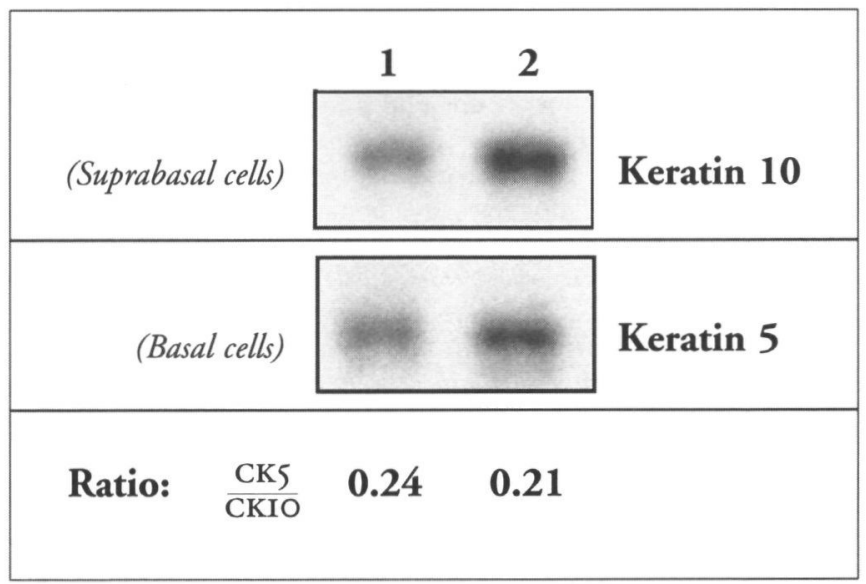

FIGURE 2 Quality control of the epidermal mRNA, before and after treatment with dispase. Northern blot analysis of (1) the total biopsy (including epidermis and dermis) and (2) epidermis after separation. Hybridizations were performed using Keratin 10 and Keratin 5 as probes to compare the ratios between basal and suprabasal cells. 
The main aim of this study was to obtain a (partial) transcriptome of human epidermis, and a second aım was to compare these data with our previous findings on SAGE expression profilıng in keratınocytes cultured under conditions that favor normal differentiation in a submerged system as previously described " $"$ Messenger RNA from human epidermis was purified and analyzed using MicroSAGE A total number of 27,860 tags was generated from the two libraries In table 1 we have summarized the number of tags sequenced in two libraries from human epidermis and cultured cells Within these libraries a large number of tags corresponding to genes known to be highly expressed in epidermis were identified, as well as genes not previously known to be expressed by keratinocytes SAGE analysis generates frequency tables of expressed genes, which for obvious reasons cannot be depicted here in their entirery The full caralogues of expressed genes in vitro and in vivo are accessible through our website (http//dermatology azn $\mathrm{nl} /$ ) As such, these libraries contain a wealth of information on new genes that are potentially involved in skin function or that are candidate genes in genetic skun diseases A significant proportion of the tags was only encountered once, comprising almost $40 \%$ of the generated data Obviously, these tags are not useful for quantitative purposes An estımated $10 \%$ of the tags that is only encountered once probably represent artifacts introduced during SAGE procedures or sequencing ${ }^{31}$ Only a small number of transcripts is highly expressed ( $>20$ tags per library), comprising approximately $30 \%$ of all sequenced tags TABLE 1 shows that the number of unique transcripts identufied for keratinocytes in vivo is 7,645 and in vitro is 5,814 Clearly, the number of sequenced tags should be extended to obtain a complete and reliable coverage of all expressed genes under these situations, as was performed for Saccharomyces cerevistae ${ }^{12}$

\section{Comparison of $i n$ vivo and $i n$ vitro gene expression profiles}

TABLEs 2 and 3 show the twenty tags that are expressed at the highest level in human epidermis and in cultured keratinocytes Most of these tags match unique genes in the public databases and the corresponding accession numbers are given Surprisingly a few highly expressed tags cannot be assigned to known genes, and probably represent new genes A number of tags refer to more than one known gene in the databases (indicated as multuple matches) The most striking finding is that in epidermis the housekeeping genes (notably ribosomal proterns) are among the highest scorıng tags, whereas in cultured cells high expression levels of typical kerattnocyte-specific genes are found such as cytokeratıns and small prolıne-rich proteins In both librarıes galectın-7 and cytokeratın 10 are found at high levels Because cytokeratin 10 and galectin-7 are markers for epidermis-specific terminal differentiation, we conclude that in this respect the model system used to induce keratınocyte differentiation mimics normal sken The presence of cytokeratin 17 and cytokeratin 6 in the cultured cells indicate that these cultures, although they resemble normal epidermis, have the phenotype of activated cells because these genes are normally silent in resting human epidermis

Subsequently, we made a comparison of all tags from the two libraries using the SAGE software package (SAGE 2000 version 412 ) TABLE 4 shows a comparison of all genes expressed in the two libraries Transcripts are arranged in descending order of significance (all values $\mathrm{P}<001$ ) Only transcripts with a reliable match in the public database of GenBank are depicted A number of expected differences emerge from this list Genes such as cytokeratin 6 " MRP-8, MRP-14 ", SKALP/elafin "35, SLPI , psoriasin " and PA- 


\section{TABIE I Irequency distribution of identilied transcripts in SACiE libraries}

of human epidermis and culured licranocyes

\section{Frequency}

distribution

\section{$>20$ tags}

5-19 rags

2-4 tags

$1 \mathrm{tag}$

Total

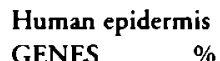

GENES \%

$$
91
$$

291

1,058

6,205

7,645

$\begin{array}{rr}1.2 & 3,790 \\ 3.8 & 2,580 \\ 13.8 & 2,556 \\ 81.2 & 6,205 \\ & 15,131\end{array}$

TAGS

$\%$
25.0
171
169
410

Cultured keratinocytes

GENES $\quad \% \quad$ TAGS $\quad \%$

$\begin{array}{rr}80 & 14 \\ 228 & 39 \\ 928 & 160 \\ 4,578 & 787 \\ 5,814 & \end{array}$

3,820

300

16.0

180

36.0

\section{2 Top 20 expressed genes in human epidermis}

\begin{tabular}{|c|c|c|c|}
\hline Tag sequence & Accession no. & Gene description & No. of tags \\
\hline CGCCGCCGGC & U12465 & Rubosomal protein L35 & 115 \\
\hline TAAACCTGCT & NM_002307 & Galectun-7 & 97 \\
\hline GAAAACAAAG & NM_000421 & $\begin{array}{l}\text { Keratın } 10 \text { (epıdermolyuc hyperkerarosis, } \\
\text { keratosis palmarıs et plantarıs) }\end{array}$ & 00 \\
\hline AGGCTACGGA & $\mathrm{AB} 028893$ & Rubosomal proten $\mathrm{Ll3}_{\mathbf{a}}$ & 84 \\
\hline TGTGCTAAAT & NM_000995 & Rubosomal protein L34 & 76 \\
\hline TTGGTCCTCT & & Multuple match & 73 \\
\hline GGGCTGGGGT & & Multuple match & 70 \\
\hline TCCCGTACAT & & No match & 67 \\
\hline GGTGAAGACA & AB002373 & KIAA0375 proteIn & 67 \\
\hline GTGAAGGCAG & $\times 53777$ & Rubosomal protein S3a & 64 \\
\hline AGCTCTCCCT & M77234 & L23 mRNA purarıve ribosomal protein & 64 \\
\hline GAGGGAGTTT & $\mathrm{U} 14968$ & Rubosomal protein $\mathrm{L} 27 \mathrm{a}$ & 63 \\
\hline TAGGTTGTCT & & Multuple match & 61 \\
\hline CTGGGTTAAT & NM_001022 & S19 rıbosomal proteın & 60 \\
\hline CGCTGGTTCC & NM_000975 & Rubosomal protein L11 & 59 \\
\hline GTGACCACGG & & Muluple match & 57 \\
\hline \multirow[t]{2}{*}{ ACCTCCACTG } & BG150312 & Likely ortholog of rat keratınocyre & \\
\hline & & differentıation associated protein & \\
\hline TGCACGTTTT & NM_000994 & Rubosomal protein L32 & 50 \\
\hline CCCGTCCGGA & BC000851 & Rubosomal proteın L13 & 53 \\
\hline CCTGTAATCC & & Multuple match & 5 \\
\hline
\end{tabular}

FABP ${ }^{38}$ are known to be absent or expressed at low levels in normal human epidermis, whereas they are strongly upregulated in activated epidermis in vivo (psoriasis) and in cultured cells. These findings fit very well with known expression levels as assessed with Northern blor analysis in previous studies by ourselves and others ${ }^{26}{ }^{38}{ }^{39}$. Figure 3 shows a comparison of SAGE data from the two libraries expressed as tag frequencies, and results from Northern blot analysis on the same material that was used to construct the SAGE lıbraries. The results demonstrate that the ratıo of gene expression within the two libraries 


\begin{tabular}{|c|c|c|}
\hline Tag sequence & Accession No. & Gene description \\
\hline TAAACCTGCT & NM_002307 & Galectın-7 \\
\hline CTTCCTTGCC & NM_000422 & Keratın 17 \\
\hline GATGTGCACG & NM_000526 & $\begin{array}{l}\text { Keratın } 14 \text { (epidermolysıs bullosa sımplex, } \\
\text { Dowling-Meara, Koebner) }\end{array}$ \\
\hline TGTGTTGAGA & J04617 & Eukaryotıc translation elongation factor 1 alpha 1 \\
\hline CCCAAGCTAG & NM_001540 & Heat shock $27 \mathrm{kD}$ proteın 1 \\
\hline CCCTTGAGGA & NM_003125 & Small prolıne rich protein (sprl) mRNA (Cornıfin) \\
\hline CTAAGACTTC & & No Match \\
\hline GAAAACAAAG & NM_000421 & $\begin{array}{l}\text { Keratın } 10 \text { (epıdermolytıc hyperkeratosis; } \\
\text { keratosis palmarıs et plantaris) }\end{array}$ \\
\hline GCCGTGTCCG & NM_001010 & Rubosomal proteın $\mathrm{S6}$ \\
\hline CCCGTCCGGA & $\mathrm{BC} 007563$ & Ribosomal protein L13 \\
\hline TGGTGTTGAG & NM_022551 & Ribosomal proteın S18. \\
\hline TTGGTCCTCT & & Muluple match \\
\hline CCTGTAATCC & & Multiple match \\
\hline ATCCTTGCTG & NM_005213 & cystaun A (stefin A) \\
\hline CCACAGGAGA & AJ 251830 & p53-induced protein PIGPCI \\
\hline ACATTTCAAA & AF304164 & Keratin 1 (epidermolytic hyperkeratosıs) \\
\hline CCCATCGTCC & & No match \\
\hline AAAGCACAAG & J00269 & Keratin 6A \\
\hline CTCAACATCT & NM_001002 & Acidic ribosomal phosphoproteın P0 mRNA, complete co \\
\hline CTGTCACCCT & S73288 & Small prolıne-rıch proteın SPRK \\
\hline
\end{tabular}

resembles the expression seen on the Northern blots. TABLE 4 also reveals similar unexpected findings as TABLES 2 and 3 with respect to epidermis-specific transcripts. Whereas in the cultured cells involucrin and stratum corneum chymotryptic enzyme are readily detected, they are undetectable in the library from epidermis. This is not caused by specific loss of the stratum granulosum during the isolation procedure because other stratum granulosum transcripts, e.g. cystatin $\mathrm{M} / \mathrm{E}$ and SLPI ${ }^{7}$ ", are present in the epidermal library. Although involucrin is abundant at the protenn level in human epidermis, it is apparently expressed at low levels at the mRNA level because Northern blot analysis showed the same findings as SAGE: no detectable signal in epidermis and a detectable signal in cultured cells. Loricrin, another abundant epidermal protern, was also absent in our SAGE libraries. The differences in mRNA and protein levels can be explained by many factors such as translation efficiency, and stability of mRNA and protein. This phenomenon has previously been encountered by Gygi et al. ${ }^{40}$. They reported that the correlation between mRNA and prorein levels was not sufficient to predict protein levels from quantitative mRNA data or vice versa. This might in part also explan the differences we find when comparing the keratinocyte $2 \mathrm{D}$ protein database ${ }^{13}$ with our transcript database. The $2 \mathrm{D}$ database contains 865 known protein spots, which represent 149 single genes of which we could identify 95 transcripts in our database. The absence in a SAGE library of a gene that is highly expressed at the protein level could also be explained by factors that are inherent to the SAGE methodology. In the case of loricrin, the presence of a CATG sequence (the NLIII restriction site used in the SAGE protocol) close to the polyadenylation signal, could preclude the generation of a reliable SAGE tag. In general, heterogeneity in polyadenylation cleavage sites ${ }^{41}$ can result in loss of the NLallI restriction site or induction of a site that is slightly changed resulting in another tag. Another explanation for the absence of individual genes that one would expect to be present could be a polymorphism in the genome from the individual from which the SAGE library was derived. Obviously, this is one of the flaws of the 


$\begin{array}{lll}1 & 2 & \\ & & \\ & \text { Keratin } 10 & (98: 87) \\ & \text { Keratin } 16 & (11: 1) \\ & & \\ \text { PRA-FABP } & (27: 7) \\ & & \\ & & \\ & & \\ & \end{array}$

FIGURE 3 Verification of SAGE data by Northern blot hybridization. Lane 1: cultured keratinocytes; lane 2: human epidermis. Equal loading was verified by methylene blue staining of $28 \mathrm{~S}$ rRNA. PA-FABP, psoriasis-associated fatty acid binding protein; MRP-8, migration inhibitory factor-related protein 8 . Besides the gene names ratios found according to SAGE are shown.

TABLE 4 Top 50 of transcripts with significantly differential expression between keratinocytes in vitro and in vivo

$\begin{array}{lrrll}\text { Tag sequence } & \text { In vivo } & \text { In vitro } & \text { Accession no. } & \text { Gene description } \\ \text { CTTCCTTGCC } & 13 & 184 & \text { X05803 } & \text { Keratin 17 } \\ \text { TAAACCTGCT } & 98 & 324 & \text { L07769 } & \text { Galectin-7 } \\ \text { GATGTGCACG } & 32 & 179 & \text { NM_000526 } & \text { Keratin 14 } \\ \text { CCCTTGAGGA } & 4 & 113 & \text { NM_003125 } & \text { Small proline rich protein 1B (cornifin) (SPRR1B) } \\ \text { CCCAAGCTAG } & 7 & 113 & \text { X54079 } & \text { Heat shock protein HSP27 } \\ \text { CTGTCACCCT } & 0 & 54 & \text { S73288 } & \text { Small proline-rich protein SPRK } \\ \text { AAAGCACAAG } & 3 & 58 & \text { J00269 } & \text { Keratin 6B } \\ \text { GGTGAAGACA } & 68 & 1 & \text { AB002373 } & \text { KIAA0375 protein } \\ \text { CTCAACATCT } & 8 & 55 & \text { M17885 } & \text { Acidic ribosomal phosphoprotein P0 } \\ \text { GCCGTGTCCG } & 21 & 77 & \text { M20020 } & \text { Ribosomal protein S6 } \\ \text { ATCCTTGCTG } & 14 & 64 & \text { NM_005213 } & \text { Cystatin A (Stefin A) (CSTA) } \\ \text { GATCTCTTGG } & 4 & 44 & \text { M87068 } & \text { S100 calcium-binding protein A2 } \\ \text { TTGGGGTTTC } & 5 & 46 & \text { L20941 } & \text { Ferritin heavy chain } \\ \text { GTGGCCACGG } & 2 & 33 & \text { NM_002965 } & \text { Calcium-binding protein in macrophages (MRP-14) } \\ \text { TGTGGGAAAT } & 9 & 43 & \text { AF114471 } & \text { Secretory leukocyte proteinase inhibitor (SLPI/ALP) } \\ \text { GCTTTATTTG } & 0 & 24 & \text { X00351 } & \text { Beta-actin } \\ \text { GAGGGAGTTT } & 64 & 12 & \text { U14968 } & \text { Ribosomal protein L27a } \\ \text { CTAGCCTCAC } & 0 & 23 & \text { M16247 } & \text { Gamma-actin } \\ \text { CGCCGCCGGC } & 116 & 41 & \text { U12465 } & \text { Ribosomal protein L35 } \\ \text { GCCCCTGCTG } & 13 & 46 & \text { M19723 } & \text { Keratin 5 } \\ \text { GGGGAAATCG } & 2 & 26 & \text { M92381 } & \text { Thymosin beta 10 } \\ \text { CTTCCAGCTA } & 7 & 33 & \text { NM_004039 } & \text { Annexin-2 } \\ & & & & \end{array}$




\begin{tabular}{|c|c|c|c|c|}
\hline Tag sequence & In vivo & itro & Accession no. & Gene description \\
\hline CCTTCGAGAT & 7 & 32 & U14970 & Rubosomal protein S5 \\
\hline GTTTTTCATT & 31 & 2 & AB027289 & Cyclın-E bindıng proteın 1 \\
\hline CCCTGGGTTC & 3 & 24 & M10119 & Ferritın light subunit \\
\hline TGTTCTGGAG & 24 & 0 & $\times 52947$ & Cardıc gap junction protein. \\
\hline ATTCTCCAGT & 43 & 8 & $\times 52839$ & Rubosomal proteın L17 \\
\hline ATAАТТСТTТ & 49 & 11 & U14973 & Rubosomal protein S29 \\
\hline ATGAGCTGAC & 0 & 16 & L03558 & Cystatın B \\
\hline CCAGTGGCCC & 5 & 26 & $\mathrm{U} 14971$ & Ribosomal proteın S9 \\
\hline TTGAATCCCC & 4 & 24 & 218538 & Skun-derıved antıleukoproteınase (SKALP/Elafin) \\
\hline TAATAAAGGT & 52 & 13 & NM_001012 & Rubosomal proteın 58 \\
\hline ATTATTTTTC & 39 & 7 & $\times 52967$ & Ribosomal proteın L7 \\
\hline TCAGATCTIT & 47 & 11 & $\mathrm{M} 22146$ & Scar protein \\
\hline TAAGGAGCTG & 29 & 3 & X69654 & Ribosomal proteın S26. \\
\hline GTTGTGGTTA & 38 & 7 & ABO21288 & Beta 2-microglobulin \\
\hline CAGCTATTTC & 7 & 27 & M94856 & Fatty acid binding protein homologue (PA-FABP) \\
\hline TGGTGTTGAG & 40 & 71 & $\times 69150$ & Rubosomal protein $S 18$ \\
\hline GCCTACCCGA & 1 & 16 & $\mathrm{X} 13425$ & Pancreatic carcinoma marker GA733-1 \\
\hline GAACACATCC & 7 & 26 & $\mathrm{X} 63527$ & Rubosomal protein L19 \\
\hline CGCCGGAACA & 7 & 25 & $\mathrm{D} 23660$ & Ribosomal protein L4 \\
\hline ATCCAGAGGC & 0 & 12 & $\mathrm{~L} 42612$ & Keratin 6 isoform K6f (KRT6F) \\
\hline TACCTGCAGA & 0 & 12 & $\mathrm{X06234}$ & Calcium-binding protein in macrophages (MRP-8) \\
\hline TAGGTTGTCT & 62 & 22 & $\mathrm{X} 16064$ & Translationally controlled tumor protein. \\
\hline GAAAAATGGT & 28 & 5 & $X 61156$ & Lamının-bındıng proteın \\
\hline GTGTTAACCA & 4 & 19 & $\mathrm{~L} 25899$ & Rubosomal protein L10 \\
\hline TCTCCTGGAC & 0 & 11 & AF 168768 & Stratum corneum tryptic enzyme (SCTE) \\
\hline ТСТСТТТААТ & 0 & 11 & M13903 & Involucrın \\
\hline GACGACACGA & 8 & 25 & $\mathrm{U} 58682$ & Rubosomal protein S28 \\
\hline CACCACCACC & 15 & 0 & U09585 & Putative interferon-related proteın (SM15) \\
\hline
\end{tabular}

SAGE rechnology. Because of the complexity of the technique and the large sequencing efforts required to obtain these libraries, the throughput is low. Once all the genes within the human genome have been reliably identified, parallel methods for expression profiling (e.g. micro-arrays) will be the preferred method. At present, SAGE is a still a valuable methodology because it allows fairly accurate quantitative determination of expression levels, sensitivity can be increased upon demand simply by sequencing larger libraries, and finally SAGE allows, in principle, detection of new, unique tags and identification of their cognate genes.

\section{Functional classification of expressed genes}

To obtain a better view on differences between keratinocytes in vivo and in vitro we classified the transcripts into different functional categories. Using a database relying on data retrieved from TIGR (http://www.tugr.org/) we sorted the transcripts into different categories, thereby omitting a large amount of transcript that could not be easily assigned to a specific caregory (TABLE 5). From taBle 5 which represents a simplification of our classification it is clear that cultured keratinocytes express more tags involved in cell structure and 


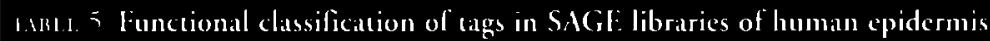

and cultured keratinocyte

$\begin{array}{ll}\text { Percentage of classified tags } \\ \text { Category } & \text { Human epidermis Cultured keratinocytes }\end{array}$

Cell division

$\begin{array}{rr}3 & 2 \\ 7 & 10 \\ 10 & 26 \\ 4 & 5 \\ 69 & 47 \\ 7 & 10\end{array}$

1.131: 6, Possible keratinocyer specific tags, chus far noe found in other SAcil libraries

\begin{tabular}{|c|c|c|c|}
\hline Tag sequence & No. of tags & UniGene code & Gene description \\
\hline GTCACTGGGC & 21 & Hs 112457 & $\begin{array}{l}\text { likely ortholog of rat keratinocyte } \\
\text { differentiation associated protein }\end{array}$ \\
\hline GCAGCTACGG & 7 & & Unknown \\
\hline ССТАТTТСАТ & 6 & & Unknown \\
\hline GTGGAGGATT & 5 & & Unknown \\
\hline GAGTGAAGCT & 5 & $\mathrm{H}_{5} 188757$ & Homo sapiens, clone MGC.5564, mRNA, complete cds \\
\hline ACCTTGGTGC & 5 & & Unknown \\
\hline CCCAGGTGAC & 4 & & Unknown \\
\hline ATTCTAGCAC & 4 & Hs 31314 & recinoblastoma-binding protern 7 \\
\hline ACTCAAAGGG & 4 & & Unknown \\
\hline TGGGAAACTA & 4 & & Unknown \\
\hline
\end{tabular}

motility, and epidermis express more tags involved in gene and protein expression. Taking a closer look at TABLE 5 and the subdivisions (data not shown) we see that the difference in cell structure and motility is due to the fact that keratinocytes in vitro express far more tags for cytoskeletal genes than keratinocytes in vivo. Within the group of gene and protein expression we found that the differences are caused by the high expression of tags encoding ribosomal proteins in keratinocytes in vivo.

\section{Novel keratinocyte-specific transcripts}

Finally, we invesugated if our SAGE analyses contained novel transcripts that were specific for keratinocytes, in addition to known epidermis-specific genes. We therefore compared all tags from the human epidermal SAGE library with all tags deposited at the NCBI, which are derived from a variety of cell lines and tissues. This analysis revealed that keratınocytes indeed produce tags that are not found in other cells. Comparison of 15,131 epidermal tags with a total of 389,438 unique tags within 100 libraries at the NCBI, we end up with about 1,100 tags not previously reported. Within this group 10 tags were expressed more than three umes, 
which makes it unlikely that they are artifacts introduced by various steps in the SAGE protocol (PCR or sequencing errors). These tags might represent novel keratinocyte-specific transcripts. Most of these tags could not be identified within the public mRNA or EST databases and we surmise that they correspond to hitherto unidentified genes. A list of keratinocytespecific tags that occur more than three times in our database is given in TABLE 6 . We are currently cloning the corresponding cDNAs, and in furure experiments we will try to establish their relevance for skin function.

\section{Conclusions}

The data presented here are a first attempt to generate a partial transcriptome of human epidermis. Obviously a far larger number of tags need to be sequenced to obtain a complete picture of expressed genes in this tissue. Even this limited SAGE analysis has provided us with a wealth of information with respect to expression profiles of human keratinocytes, identification of novel genes, and differences between in vivo and in vitro conditions. We are currently using these SAGE data as an inpur for tissue-specific microarrays, that can address epidermal gene expression in high-throughput format. Bioinformatics tools such as tag-to-gene and gene-to-tag mapping, that are freely available on the web (at the NCBI) can be useful to detect potentially transcribed sequences in genomic regions of interest, and to search for candidate genes in human skin diseases.

\section{Acknowledgements}

We gratefully thank Dr. K.W. Kinzler, Johns Hopkins Oncology Center, Baltimore, MD, for advise and providing the SAGE protocol and the SAGE Software package, Dr. T. Magnaldo, Laboratoire de Génétique Moléculaire, Centre National de la Recherche Scientifique, Villejuif, France, and Dr. P. Madsen, Department of Medical Biochemistry, University of Aarhus, Denmark. for providing us with cDNA probes for respectively keratin 10, keratin 5 (Magnaldo), PA-FABP (Madsen). This work was supported by the Dutch Cancer Society (research grant 1998-1781) and The Netherlands Organization for Scientific Research (NWO, grant 902-11-092).

Note The libraries described in this Chapter have been deposited at the Gene Expression Omnibus (hetp//www ncbi nlm nih gov/geo/) under the following accession numbers GSM1121. SAGE library derived from cultured keratınocytes, GSM1123 SAGE library derived from human epidermis Both libraries can be accessed through the SAGE website at hrtp //www ncbi nlm nih gov/SAGE/ 
1. Eckert RL, Crish JF, Banks EB, Welrer JF. The epidermus: genes on - genes off J Invest Dermatol 1997;109(4):501-9.

2. Sunha S, Degenstein L, Copenhaver C, Fuchs E. Definung the regulatory factors required for epidermal gene expression Mol Cell Bıol 2000;20(7)-2543-2555.

3. Otren HG, Bor B, Ververs C, Verdonck LF, De Boer M, De Gast GC Alloanugen-specific T-cell anergy induced by human kerarinocyres is abrogated upon loss of cell-cell contact. Immunology 1996;88(2):214-9.

4. Frohm $M$, Agerberth $B$, Ahangari G, Stahle-Backdahl M, Liden S, Wigzell H, et al The expression of the gene coding for the antibacterıal peptide LL-37 is induced in human keratinocytes durıng inflammatory disorders. J Biol Chem 1997,272(24):15258-63.

5. Harder J, Bartels J, Christophers E, Schroder JM A pepude antibıotic from human skın Nature 1997;387(6636)·861

6. Pfundr R, Van Ruissen F, Vlımen-Willems IM, Alkemade HA, Zeeuwen PL, Jap PH, et al Consturutive and inducible expression of SKALP/elafin provides antı-elastase defense in human epithelia.

J Clin Invest 1996;98(6)·1389-1399

7 Wingens $M$, van Bergen BH, Hiemstra PS, Mers JF, Vlımen-Willems IM, Zeeuwen PL, et al. Induction of SLPI (ALP/HUSI-I) in epidermal keratınocytes J Invest Dermatol 1998,1 11(6).996-1002.

8. Kupper TS The activated keratınocyte- a model for inducible cyrokune production by non-bone marrow-derived cells in cutaneous inflammatory and immune responses J lnvest Dermatol 1990;94(6 Suppl)' 146S-150S.

9 Barker JN, Mitra RS, Griffiths CE, Duut VM, Nickoloff BJ Keratinocytes as inıtıators of Inllammation. Lancet 1991,337(8735) 211-4

10. Eckert RL, Crish JF, Robınson NA The epidermal keratinocyte as a model for the srudy of gene regulation and cell differentiation Physiol Rev 1997;77(2).397-424

11 Eckert RL Structure, function, and differentiation of the keratinocyre. Physiol Rev 1989;69(4):1316-46

12. Fuchs E. Keratins and the skan Annu Rev Cell Dev Bıl 1995;11 123-53.
13. Celis JE, Rasmussen HH, Gromov $P_{1}$ Olsen E, Madsen $\mathrm{P}$, Leffers $\mathrm{H}$, et al. The human keratınocyte two-dimensional gel proteın database (update 1995): mapping components of signal transducrion pathways. Electrophoresis 1995;16(12):2177-240

14 Karz AB, Tachman LB A parral catalog of proteıns secreted by epidermal keratınocytes in culture J Invest Dermatol 1999;1 12(5)·818-21

15. Kuta H, Okubo K, Matsubara K An expression profile of active genes in cultured human keratınocytes. DNA Res 1996,3(1):1-7.

16. Konush K, Morishima Y, Ueda E, Kube Y, Nonomura K, Yamanıshı K, et al. Catalogıng of the genes expressed in human kerarinocytes analysis of 607 randomly isolated cDNA sequences Biochem Biophys Res Commun 1994;202(2).976-983

17 DiSepio D, Ghosn C, Eckert RL, Deucher A, Robinson N, Duvic $M$, et al Identification and characierizarion of a reunoid-induced class II tumor suppressor/growth regulatory gene. Proc Natl Acad Sc1 U S A 1998;95(25):14811-5

18. Frank $S$, Werner $S$. The human homologue of the yeast $\mathrm{CHLl}$ gene is a novel keratinocyte growth factor-regulated gene.

J Bıl Chem 1996;271(40):24337-40.

19 Frank S, Munz B, Werner S. The human homologue of a bovine non-selenium glutathione peroxidase is a novel keratinocyte growth factorregulated gene. Oncogene 1997;14(8) 915-21

20. Munz B, Gerke V, Gillıtzer R, Werner $S$ Differential expression of the calpactin I subunits annexın II and pl1 in cultured keratınocytes and during wound reparr J Invest Dermatol 1997;108(3)·307-12.

21. Rivas MV, Jarvis ED, Morisaks $S$, Carbonaro $H$, Gottieb AB, Krueger JG. Identification of aberrantly regulated genes in diseased skın using the cDNA differential display technique. J Invesr Dermatol 1997;108(2)・188-94

22. Rurberg SE, Lee EJ, Hansen LH, Glıck AB, Yuspa SH. Identification of differentıally expressed genes in chemically induced skun tumors Mol Carcınog 1997;20(1):88-98 
23 Trenkle I, Welsh J, Jung B, Machieu-Daude F, McClelland $M$ Non-storchiometric reduced complexuty probes for $\mathrm{CDNA}$ arrays. Nucleıc Acids Res 1998;26(17) 3883-91

24. Jansen BJH, Van Russen F, De Jongh G, Zeeuwen PLJM, Schalkwıjk J Serıal Analysıs of Gene Expression in Differentiated Cultures of Human Epidermal Keratinocytes J Invest Dermatol 2001;1 16(1) 12-22

25. Datson NA, Perk-de Jong J, van den Berg MP, de Kloer ER, Vreugdenhil E. MicroSAGE: a modified procedure for serial analysıs of gene expression in limited amounts of tissue Nucleic Acids Res 1999,27(5) 1300-1307.

26. Van Russen F, de Jongh GJ, Zeeuwen PL, van Ep PE, Madsen P, Schalkwikk J Induction of normal and psoriatic phenotypes in submerged keratinocyte cultures J Cell Physiol 1996,168(2):442-452.

27 Velculescu VE, Zhang L, Vogelstein B, Kunzler KW. Serial analysis of gene expression. Science 1995;270(5235):484-487

28. Kenzelmann M, Muhlemann K. Substantially enhanced cloning efficiency of SAGE (Serial Analysis of Gene Expression) by addung a heating step to the original protocol.

Nucleıc Acıds Res 1999;27(3)-917-918

29 Benson DA, Karsch-Mızachı I, Lipman DJ, Ostell J, Rapp BA, Wheeler DL GenBank Nucleic Acids Res 2000,28(1).15-18

30 Van Ruissen F, Le M, Carroll JM, van der Valk PG, Schalkwıjk J. Differentıal effects of detergents on keratınocyie gene expression J Invest Dermatol 1998;1 10(4):358-363.

31 Yamamoto M, Wakatsuki T, Hada A, Ryo A. Use of serial analysis of gene expression (SAGE) technology.

J Immunol Methods 2001,250(1-2):45-66.

32 Velculescu VE, Zhang L, Zhou W, Vogelstein J, Basra MA, Bassert DE, Jr., et al. Characterization of the yeast transcriptome.

Cell 1997;88(2)·243-251

33. Weiss RA, Eichner R, Sun TT. Monoclonal antibody analysis of keratin expression in epidermal diseases a 48- and 56-kdalton keratin as molecular markers for hyperproliferative keratınocytes. J Cell Bıol 1984;98(4):1397-1406.

34. Kunz M, Roth J, Sorg C, Kolde G. Epiderma expression of the calcium binding surface antigen 27E10 in inflammatory skın diseases Arch Dermatol Res 1992;284(7):386-390
35 Nonomura K, Yamanıshı K, Yasuno H, Nara K, Hirose $S$ Up-regulation of elafin/SKALP gene expression in psoriatic epidermıs. J Invest Dermarol 1994;103(1)'88-91

36. Schalkw1jk J, Chang A, Janssen P, de Jongh GJ, Mier PD Skın-derived antileucoproteases (SKALPs) characterization of two new elastase inhibitors from psoriatic epidermis.

Br J Dermarol 1990;122(5)·631-641.

37. Madsen P, Rasmussen $\mathrm{HH}$, Leffers $\mathrm{H}$, Honore B, Dejgaard K, Olsen E, et al Molecular cloning, occurrence, and expression of a novel partially secreted prorein "psoriasin" that is highly up-regulated in psoriatic skın J Invest Dermatol 1991;97(4):701-712.

38 Madsen P, Rasmussen HH, Leffers $\mathrm{H}$, Honore B, Celis JE. Molecular cloning and expression of a novel keratinocyte protein (psoriasis-2ssociated fatty acid-binding proteın [PA-FABP]) that is highly up-regulated in psoriatic skın and that shares similaricy to fatry acid-binding proteins. J Invest Dermatol 1992,99(3):299-305.

39. Zeeuwen PL, Vlymen-Willems IM, Jansen BJ, Soturopoulou G, Curfs JH, Mets JF, et al. Cystatun M/E Expression is Restricied to Differentiated Epidermal Keratinocyres and Sweat Glands. a New Skun-Specific Proteinase Inhibitor that is a Target for Cross-Lınkung by Transglutamınase. J Invest Dermatol 2001;116(5) 693-701.

40 Gygı SP, Rochon Y, Franza BR, Aebersold R Correlation berween protein and mRNA abundance in yeast. Mol Cell Bıol 1999;19(3).1720-1730.

41. Pauws E, van Kampen AH, van de Graaf SA, de Vijlder JJ, Rus-Stalpers C Heterogenerty in polyadenylation cleavage sites in mammalian mRNA sequences: Implications for SAGE analysis Nucleic Acids Res 2001;29(8):1690-1694 
CHAPTER 5

\section{TNF-related apoptosis inducing ligand (TRAIL) triggers apoptosis in human epidermal keratinocytes in the absence of internucleosomal DNA fragmentation}

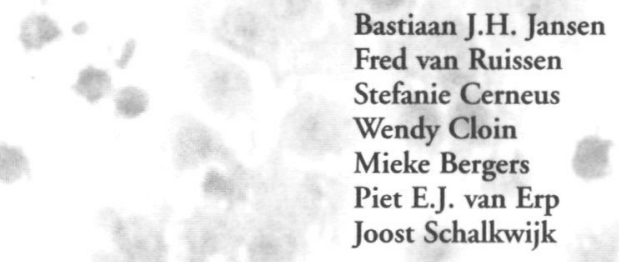

Department of Dermatology 802

University Medical Center St. Radboud PO Box 9101

6500HB Nijmegen

The Netherlands

This Chapter has been submitted for publication 

Using Serial Analysis of Gene Expression (SAGE) we have previously identified the expression of several pro- and anti-apoptotic genes in cultured human primary epidermal keratinocytes, including TNF-related apoptosis inducing ligand (TRAIL). Here we present a study on the effect of TRAIL on cultured keratinocytes. It is shown that differentiated and undifferentriated keratinocytes undergo apoptosis after addition of TRAIL to the medium as determined by morphological and biochemical criteria, like activation of caspases- 3 and -8 . Induction of terminal differentiation in the absence of TRAIL does not induce apoptosis. In contrast to the promyelocytic cell line HL60, internucleosomal DNA fragmentation does not occur in keratinocytes, as assessed by flow-cytometric analysis and agarose gel-electroforesis. Reverse transcription polymerase chain reaction (RT-PCR) showed low to undetectable levels of human DNA fragmentation factor of $40 \mathrm{kDa}$ (DFF40) in human keratinocyres and epidermis, whereas this gene was expressed at appreciable levels in HL60 cells. The absence of DFF40 in keratinocytes may explain the absence of internucleosomal DNA fragmentarion during apotosis and terminal differentiation. Our data indicate that programmed cell death during keratinocyte differentiation is distinct from apoptosis in response to cytotoxic, biochemical stimuli. 


\section{Introduction}

Human epidermis is a stratıfied, squamous epithelium mostly consisting of keratinocytes, and constitures the outermost part of the skun Basal, proliferating keratinocytes supply the outer layers of the epidermis with keratinocyres that are set to undergo a terminal differentiation program This tightly coordinated, complex program ultımately leads to the the formation of the stratum corneum, a layer of deceased cells that are covalently linked through a network of structural proteins, thus providing a defensive barrier against biological, chemical and physical stımulı ${ }^{1-4}$ There is evidence that apoptosis and terminal differentiation are two distinct processes terminal differentiation is not associated with membrane blebbing and nuclear condensation, and the process requires days to complete, as opposed to hours for apoptosis " Interestingly, it has recently been shown that the typical pro-apoptotic, short prodomain effector caspases-3, -6 and -7 are not activated during terminal differentiation in the epidermıs Terminal differentıation does, however, involve the skın-specific caspase-14 which is exclusively expressed in the stratum granulosum, a layer just below the stratum corneum of the epidermıs ${ }^{6} 7$

In addition to the normal pathway of programmed cell death during terminal differentiation, keratinocytes have the armament to undergo apoptosis upon genomic and toxic insult High doses of ultraviolet (UV) irradiation induce apoptosis, either directly by DNA damage ${ }^{10}$, activation of the tumor suppressor p53 1112 , direct triggening of cell death receptors ${ }^{13} 14$, or autocrine release of death ligands ${ }^{15}$ Furthermore, several clinical conditions are associated with excessive apoptosis in the epidermis Autocrine expression of FasL has been described in toxic epidermal necrolysis (TEN), a severe adverse, drug-induced reaction in which keratınocytes die and epidermis separates from the dermıs ${ }^{16}$, and a role of T-cell mediated FasL-induced apoptosis in keratınocytes has been established for varıous forms of dermatutus ${ }^{17} 18$

We have previously shown, by means of Serıal Analysis of Gene Expression (SAGE), that the TNF homologue TNF-related apoprosis inducing ligand (TRAIL) is moderately expressed in keratinocytes at the mRNA level " TRAIL is known to be a porent inducer of apoptosis in various tumors and cell lines derived thereof, but it has recently been shown that TRAIL can also induce apoptosis through a caspase-dependent pathway in hepatocytes, raising concerns about the applicability of TRAIL in cancer therapy ${ }^{20}$ TRAIL can induce apoptosis in primary keratinocytes, but the apoptoric response is far less intense than in the transformed keratinocyte cell line $\mathrm{HaCaT}^{21}$, whereas others have claimed that primary keratinocytes are resistant to TRAIL-induced apoptosis ${ }^{22}$, or that sensitivity to TRAIL requires the addition of the protein synthesis inhibitor cycloheximide ${ }^{23}$ TRAIL expression has previously been established at both the mRNA and proten levels in cultured keratınocytes "2

Here we have sought to determine the effect of TRAIL on cultured keratinocytes, using a model system that allows differentiation in a submerged culture ${ }^{24}{ }^{25}$ We show that TRAIL is able to induce apoptosis in cultured keratınocytes, and that the severity of the apoptonic response is dependent on both concentration of TRAIL and differentiation state As we were unable to demonstrate internucleosomal DNA fragmentation by means of agarose gel electroforesis and flow cytometry, we investigated whether human DNA fragmentation factor of $40 \mathrm{kDa}$ (DFF40), is expressed in cultured keratınocytes and human epidermıs DFF40 is an endonuclease responsible for the typical internucleosomal fragmentation of 
genomic DNA during apoptosis and is activated upon cleavage of its inhibitor, DFF45 (also known as DNA fragmentation factor of $45 \mathrm{kDa}$; DFF45), by caspase-3 ${ }^{26}{ }^{28}$. The resulting DNA fragmentation is generally considered a biochemical hallmark of apoptosis ${ }^{29.30}$. Its absence in human epidermis and keratinocytes explains why keratinocytes do not show the typical pattern of DNA fragmentation during TRAIL-induced apoptosis.

\section{Materials \& methods}

\section{Cells \& cell culture}

Primary keratinocytes were obtained as described elsewhere ${ }^{24}$. Cells were grown to confluence $\left(10^{6}\right.$ cells) at $37^{\circ} \mathrm{C}$ in $5 \% \mathrm{CO}_{2}$ in 6 -wells tissue culture plates in keratinocyte growth medium (KGM) consisting of KBM $\left(0.15 \mathrm{mM} \mathrm{Ca}{ }^{24}\right.$; BioWhittaker, Verviers, Belgium) supplemented with ethanolamine $(0.1 \mathrm{mM}$; Sigma, St Louis, MO), phosphoethanolamine $(0.1 \mathrm{mM}$, Sigma),bovine pituitary extract $(0.4 \% \mathrm{vol} / \mathrm{vol}$; BioWhittaker, Verviers, Belgium) epidermal growth factor (10 ng/ml; Sigma), insulin $(5 \mu \mathrm{g} / \mathrm{ml}$; Sigma), hydrocortisone $(0.5 \mu \mathrm{g} / \mathrm{ml}$; Collaborative Research, Lexington, MA), penicillin (100 $\mathrm{U} / \mathrm{ml}$; Life Technologies, Gaithersburg, MD), and strepromycin $(100 \mu \mathrm{g} / \mathrm{ml} ; \mathrm{Life}$ Technologies). Cells were not switched or switched to KGM depleted of growth factors (bovine pituitary extract, epidermal growth factor, hydrocortisone, and insulin) for 24 hrs before being stimulated for various periods of time with different concentrations of TRAIL (Biomol, Plymouth Meeting, PA). HL60 cells were cultured at $37^{\circ} \mathrm{C}$ in $5 \% \mathrm{CO}_{2}$ to a density of $10^{7}$ cells $/ \mathrm{ml}$ in RPMI Complete (10\% fetal calf serum (Harlan SeraLab, Crawley Down, UK) in RPMI (ICN Biomedicals, Costa Mesa, CA), 100U/ml penicillin and 100 $\mu \mathrm{g} / \mathrm{ml}$ streptomycin). Fetal calf serum was heated for $30 \mathrm{~min}$ at $56^{\circ} \mathrm{C}$ in order to avoid effects of components that may interfere with apoptosis. HL60 cells were directly stimulated with various concentrations of TRAIL in their medium.

\section{Haematoxylin/eosin staining of cultured keratinocytes}

Keratinocytes were cultured on Thermanox coverslips (Nalge Nunc International, Rochester, NY) as indicated. Three hours after stimulation with various concentrations of TRAIL, coverslips were collected and washed in phosphate buffered saline (PBS), $\mathrm{pH} \mathrm{7,}$ and cells were fixed for $10 \mathrm{~min}$ in ice-cold methanol/aceton $1: 1 \mathrm{v} / \mathrm{v}$, incubated at $-20^{\circ} \mathrm{C}$ for $10 \mathrm{~min}$, and stored until furrher use at $-20^{\circ} \mathrm{C}$. Before staining, cells were incubated in $70 \%$ ethanol, and then stained with Mayer's haematoxylin (Sigma Chemicals, St. Louis, $\mathrm{MO}$ ) for $10 \mathrm{~min}$, washed for $10 \mathrm{~min}$ with tap water and counterstained with eosin for 90 sec. Cells were washed 3 times with $100 \%$ ethanol and incubated in histosafe for at least 5 min. Coverslips were mounted using Permount (Fisher Scientific, Fairlawn, NJ). Cells were examined under a light microscope at a magnification of $200 \mathrm{X}$ and photographed.

\section{Serial Analysis of Gene Expression}

Serial Analysis of Gene Expression was essentially carried out as described before ${ }^{31}$. Purified mRNA was used to generate SAGE libraries from both normal and TNF- $\alpha$ stimulated keratinocytes, and has been described elsewhere ". The SAGE protocol and the SAGE2000 Software Package were kindly provided by Dr. K. Kinzler (Johns Hopkins Oncology Center, Baltimore, MD). Isolated concatemers, consisting of serially ligated 
tags, were ligated into pUC18 (Invitrogen, San Diego, CA) and transformed in chemically competent MAX Efficiency DH5 $\alpha$ Escherichia coli Competent Cells (Life Technologies) by means of heat-shock transformation, following the manufacturer's protocol. Colony PCR was performed on positive colonies with pUC18-specific primers pUC18-F (5'-AAGTTGGGTAACGCCAGG-3') and pUCi 8-R (5'-GGCTCGTATGTTGTGTGG-3') and PCR products were analyzed by agarose gel electrophoresis. PCR conditions are available upon request. 1,800 clones were selected for DNA sequencing with the Big Dye Terminator Kit and the -21M13 sequencing primer (PE Applied Biosystems, Foster City, CA), according to the manufacturer's recommendations. Sequencing reactions were run on an ABI 310 Genetic Analyzer. Sequence data were analyzed with the SAGE2000 Software Package, and online with the SAGE analysis tools at the website of the National Center for Biotechnology Information (NCBI), Bethesda, MD (http://www.ncbi.nlm.nih.gov/SAGE/).

\section{Isolation of total RNA}

Total RNA was isolated from normal and stimulated keratinocytes, HL60 cells, isolated epidermis and whole skin biopsies by lysing cells in RNase All (2.1 M guanidine thiocyanate (Research Organics, Cleveland, OH), $8.5 \mathrm{mM}$ N-laurylsarcosine (Sigma), 12.5 $\mathrm{mM} \mathrm{NaAc}$ pH 5.2, 0.35\% v/v $\boldsymbol{\beta}$-mercaptoethanol (Merck GmbH, Darmstadt, Germany) and $50 \% \mathrm{v} / \mathrm{v}$ Tris-saturated phenol $\mathrm{pH} 8.0$ (Biosolve, Amsterdam, the Netherlands)) and rissue was grinded with a mixer. Total RNA was extracted by adding $1 / 10$ of a volume of chloroform and centrifugation at $12,000 \mathrm{xg}$ at $4^{\circ} \mathrm{C}$ for $15 \mathrm{~min}$. The aqueous phase was recovered and total RNA was precipitated by adding an equal volume of isopropanol, followed by an incubation on ice for $45 \mathrm{~min}$. RNA was pelleted by centrifugation at $12,000 \times \mathrm{g}$ for $15 \mathrm{~min}$, and the pellet was washed with $70 \%$ ethanol an dried at room temperature. The pellet was then resuspended in $0.1 \mathrm{ml} \mathrm{NSE}$ ( $50 \mathrm{mM} \mathrm{NaAc}, 0.2 \%$ sodium dodecyl sulfate, $2 \mathrm{mM}$ ethylenediamine terraacetic acid) and $375 \mu \mathrm{l} 100 \%$ ethanol was added. For quantitation, $10 \mu \mathrm{l}$ of this suspension was used to pellet RNA, and the pellet was resuspended in $1 \mathrm{ml} \mathrm{H}_{2} \mathrm{O}$. Purity and concentration of total RNA were determined spectrophotometrically.

\section{Reverse transcription polymerase chain reaction}

Total RNA was converted to single-stranded cDNA using the Superscript kit (Life Technologies, Gaithersburg, MD), following the manufacturer's guidelines. Single stranded cDNA was dilured $50 \mathrm{X}$ before a PCR was performed. PCRs were performed with AmpliTaq Gold polymerase in the supplied buffer, supplemented with $1.5 \mathrm{mM} \mathrm{Mg^{2 }}$ in a reaction volume of $25 \mu$. For the PCR to identify TRAIL, the following primers were used: TRAIL-F (5'-ACCCCAATGACGAAGAGAG-3') and TRAIL-R (5'-TCAGGAATGAATGCCCAC-3') with the following PCR conditions: 1 cycle of $95^{\circ} \mathrm{C}$ for $9 \mathrm{~min}$, followed by $35 \mathrm{cycles}$ of $95^{\circ} \mathrm{C}$ for $30 \mathrm{sec}, 54^{\circ} \mathrm{C}$ for $45 \mathrm{sec}$ and $72^{\circ} \mathrm{C}$ for $45 \mathrm{sec}$, followed by one cycle of $72^{\circ} \mathrm{C}$ for $10 \mathrm{~min}$, after which reactions were cooled to $10^{\circ} \mathrm{C}$ until further analysis. For the PCR to identify DFF40 the following primers were used: CAD435-F (5'GGAGTCCCGATTTCAGAGCAAGTC-3') and CAD816-R (CAGTGTAGGAATGATGGTGCGTTTC-3'), whereas for the internal control a $\beta$-Actin PCR was performed with the following primers: $\beta$-Actin-Left (5'-AGAGATGGCCACGGCTGCTT-3') and $\beta$-Actin-Right (5'- ATTTGCGGTGGACGATGGAG-3'). Both the DFF40 and $\beta$-Actin PCRs have been carried out using the following conditions: 1 cycle of $95^{\circ} \mathrm{C}$ for $9 \mathrm{~min}$, followed by 35 cycles of $95^{\circ} \mathrm{C}$ for $30 \mathrm{sec}, 59.2^{\circ} \mathrm{C}$ for $45 \mathrm{sec}$ and $72^{\circ} \mathrm{C}$ for $45 \mathrm{sec}$, followed by 
one cycle of $72^{\circ} \mathrm{C}$ for $10 \mathrm{~min}$, after which reactions were cooled to $10^{\circ} \mathrm{C}$ until further analysıs All PCRs were carried out in a Bıometra T1 Thermocycler (Bıometra, Gottıngen, Germany) $10 \mu \mathrm{l}$ of each reaction was run on an $1 \%$ agarose gel under standard conditions, and visualized with UV light, with ethidiumbromide as a chromophore ${ }^{32}$

\section{Protein extraction, polyacrylamide gel electroforesis and Western blot analysis}

Cultured keratınocytes were harvested at varıous tımes after stımulation with TRAIL, depending on the protein under investigation, in $150 \mu \mathrm{l} \mathrm{Laemmlı} \mathrm{buffer} \mathrm{(BioRad,}$ Hercules, $C A$ ) and $\beta$-mercaptoethanol was added to a final concentration of $5 \% \mathrm{v} / \mathrm{v}$ Samples were sonificated, boiled for $3 \mathrm{~min}$ and $15 \mu \mathrm{l}$ loaded onto $15 \%$ polyacrylamide Tris/HCl Ready Gels (BioRad, Hercules, CA) and run for 45 min at $175 \mathrm{~V}$ in buffer supplied by the manufacturer, along with Kaleidoscope prestained size standards (BıoRad, Hercules, CA) and Bıotınylated Protein Marker (Cell Signalıng, Beverley, MA) After the run, proteın was blotted onto PVDF membrane by in a Tris/Glycine/Methanol buffer at $400 \mathrm{~mA}$ for 35 minutes Membranes were washed with Tris-buffered saline/Tween-20 (TBS/T) and blocked for 1 to 2 hours in Blotto/0 1\% Tween-20 (BioRad, Hercules, CA) Then membranes were incubated overnight at $4^{\circ} \mathrm{C}$ with primary mouse antibodies, diluted 1000X in Blotto/0 1\%Tween-20, aganst either human caspase-3 (monoclonal, R\&D Sytems, Minneapolıs, MN) or human caspase-8 (monoclonal, BioSource, Camarillo, CA), each recognizing both their inactive substrates as well as activated caspases After washing with TBS/T, membranes were incubated with secondary ancibodies, biotınylated goat-antı-mouse and horse raddish peroxidase conjugated goat-anti-biotın, 1000X diluted in Blotto/0 $1 \%$ Tween-20 Membranes were washed with TBS/T, then incubated with LumıGLO (Cell Signalıng, Beverly, MA) and peroxide Membranes were then exposed to Kodak film and auroradiographs were developed after 1 min, 2 min and 75 min Autoradiographs showing caspase-3 activation were analyzed digitally with ImageMaster software, v1 0 (Pharmacia, Uppsala, Sweden)

\section{Isolation of genomic DNA and agarose gel electroforesis}

Various tıme intervals after TRAIL stımulation of keratinocytes, $15 \mathrm{ml} 2 \mathrm{X}$ lysis buffer (200mM Trıs/HCl pH 8, $10 \mathrm{mM}$ EDTA, $0,4 \%$ SDS, $400 \mathrm{mM} \mathrm{NaCl}$, and $400 \mu \mathrm{g} / \mathrm{ml}$ proteinase $\mathrm{K}$ ) was added to cultured keratinocytes submerged in $15 \mathrm{ml}$ medium Samples were incubated for 2 hours at $50^{\circ} \mathrm{C}$, and extracted twice with 1 volume phenol/chloroform 11 , followed by one extraction with chloroform DNA was precipitated with 1 volume isopropanol and centrifuged at $12,000 \mathrm{xg}$ for $45 \mathrm{~min}$ Pellets were washed twice with $70 \%$ ethanol, ardried and resuspended in $10 \mathrm{mM}$ Tris/ $\mathrm{HCl} \mathrm{pH} 8,1 \mathrm{mM}$ EDTA DNA concentration was determined spectrofotometrically, and $1 \mu \mathrm{g}$ of DNA was run on a $15 \%$ agarose gel in IX TAE (BioRad, Hercules, CA) DNA was visualızed with UV light, using ethidium bromide as a chromophore

Flow cytometry

Afer stimulation with TRAIL for 3 hours, cells were incubated with $025 \%$ trypsin in PBS for $7-8$ min at $37^{\circ} \mathrm{C}$ Trypsinization was stopped by addıng 6 vol KGM supplemented with $5 \%$ fetal calf serum (Harlan SeraLab, Crawley Down, UK) Cells were collected by gentle centrifugation $(300 \mathrm{xg}$ ) for 7-8 min and washed 3 times with PBS After the last wash, cells were resuspended in PBS contanning $1 \% \mathrm{w} / \mathrm{v}$ paraformaldehyde, incubated on ice for $15 \mathrm{~min}$, pelleted by gentle centrifugation and washed several times with PBS con- 
taining $1 \% \mathrm{w} / \mathrm{v}$ bovine serum albumine (BSA). $50 \mu 10 \mathrm{mg} / \mathrm{ml} \mathrm{RNase} A$ was added to the pellet, along with $40 \mathrm{mg} / \mathrm{ml}$ propidium iodide in PBS, and incubated in the dark for at least 15 min at room temperature, and washed and resupended in PBS. Cells were analysed on the Epics Elite flow cytometer equipped with a $\mathbf{4 0} \mathrm{mW}$ air-cooled argon laser set at 15 $\mathrm{mW}$ and tuned at a wavelength of $488 \mathrm{~nm}$. Red fluorescent propidium iodide signals were detected through a $630 \mathrm{~nm}$ long-pass filter. Usually $10^{6}$ cells were measured at a flow rate of 50 cells per second. Data were collected and analysed with the WinsList Software Package, v4.0 (Verity Software House, Topsham, ME).

\section{Results}

\section{TRAIL is expressed in human keratinocytes and epidermis}

We have have previously constructed SAGE libraries of resting and TNF- $\alpha$ stimulated keratinocytes and found that various genes involved apoptosis and survival were expressed in cultured keratinocytes, irrespective of TNF- $\alpha$ stimulation (summarized in TABLE 1). SAGE is based on the principle that a sequence tag of 10 nucleotides is sufficient to uniquely identify a transcribed mRNA. Through various molecular techniques, these sequence tags of 10 basepairs can be isolated from a fixed position within a cDNA, and can be serially cloned and sequenced. This gives rise to a database or 'expression profile', consisting of a collecrion of tags of 10 nucleotides in length, each representing a unique mRNA. SAGE therefore allows qualitative as well as quantitative analysis of genes expressed in a given tissue or cell type ${ }^{31}$. These tags can then be assigned to genes or clusters, depending on whether a tag database is extracted from GenBank files or UniGene clusters. As shown in TABLE 1, TRAIL and its receptor TRAIL-R2 (also known as DR5 or KILLER) are expressed at moderate levels in keratinocytes that have differentiated for $\mathbf{4 8}$ hrs, and from which SAGE libraries were derived. Since the tag for TRAIL also matches FLJ21411, a gene with unknown function, we examined whether TRAIL is expressed at the mRNA level in our culture model and human skin under various conditions by means of RT-PCR. The expected 298 bp basepair fragment was indeed amplified, as shown in FIGURE 1. Expression was established not only for cultured keratinocytes (lane 1, FIGURE 1), but also for human epidermis (lane 5, FIGURE 1), and in biopsies of affected and unaffected skin from a psoriasis parient (lanes 3 and 4 respectively, FIGURE 1). HL60 cells were also included because they have been used as a control throughout the study. The PCR product was cloned and sequenced, verifying that the PCR product was derived from TRAIL mRNA. Expression of TRAIL-R1 and -R2 in cultured keratinocytes has been demonstrated by others ${ }^{21}$, and both tags in TABLE 1 could exclusively be assigned to TRAIL-R2 as determined by Tag to Gene screening at http://www.ncbi.nlm.nih.gov/SAGE. Tags for TRAIL-R1 were not detected in our libraries.

\section{TRAIL induces apoptosis in cultured, primary human keratinocytes}

In order to investigate the response of keratinocytes to TRAIL, keratinocytes were obtained and cultured as described before ${ }^{24}$. Both undifferentiated (cultured to confluence) and differentiating keratinocyres (cultured to confluence, then cultured under medium withour growth factors for $24 \mathrm{hrs}$ ) were exposed to TRAIL at concentrations of 0 (negative control), 63 and $250 \mathrm{ng} / \mathrm{ml}$, and stained with haematoxylin/eosin (HE) in order to visualize morphological changes. Undifferentiated kerarinocytes readily show apoptotic, morpho- 


$\begin{array}{lrl}\text { Tag sequence } & \text { No. of tags } & \text { Corresponding gene(s) } \\ \text { CTCCTCACCT } & 20 & \text { Bak, ribosomal protein L13a } \\ \text { GCAAAACCCC } & 8 & \text { HVEM-L/LIGHT, 14 others } \\ \text { CCACTACACT } & 5 & \text { TRAIL, FLJ21411 } \\ \text { GAGGCGCTGG } & 1 & \text { Bad, N-acetylglucosaminidase alpha- (Sanfilippo disease IIIB) } \\ \text { TTAATTGGGA } & 2 & \text { Bag-1 } \\ \text { GGCATTTTTC } & 4 & \text { Bax } \\ \text { ATGCCTTTTT } & 1 & \text { Nbk/Bik } \\ \text { ACCGGTACTG } & 1 & \text { TRAIL-R2 } \\ \text { ACCAAATTAA } & 1 & \text { TRAIL-R2 (splice variant) } \\ \text { ACCATCCTGC } & 1 & \text { IEX-1, K-cadherin } \\ \text { TTCTAGTCTG } & 1 & \text { hIAP-2 } \\ \text { AACTACATAG } & 1 & \text { APR-3 } \\ \text { CTGTGATTGT } & 1 & \text { cFLIP, phosphatidylinositol glycan, class F }\end{array}$

* Based on SAGEmap d.d. 20 August 2001

FIGURE 1 TRAIL expression in human keratinocytes, unaffected and diseased skin, isolated normal epidermis, and the promyelocytic leukemia cell line HL60 as assessed by means of RT-PCR. See Materials and Methods for details. Lane 1, cultured keratinocytes, 24 hrs differentiated; lane 2, HL60 cells; lane 3, psoriatic epidermis, involved; lane 4, uninvolved skin from psoriasis patient; lane 5 , normal human epidermis; lane 6: negative control, no template. An RTPCR with $\beta$-Actin served as an internal control. TRAIL is expressed in all cells and tissues tested.

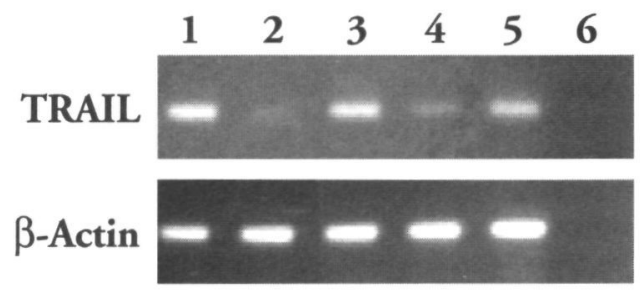

logical features, like nuclear condensation and cellular shrinkage within 3 hrs of stimulation with $250 \mathrm{ng} / \mathrm{ml}$ TRAIL (FIGURE 2C); virtually all cells had undergone apoptosis and most of them had detached from the culture dish. Cells that were allowed to differentiate for $24 \mathrm{hrs}$ were less sensitive to TRAIL-induced apoptosis, as shown in FIGURE 2F. The number of intact cells in undifferentiated keratinocytes appeared to be lower as compared to differentiating cells at a concentration of $63 \mathrm{ng} / \mathrm{ml}$ TRAIL (FIGUREs 2B and 2E). Negative controls do not display apoptotic morphology, indicating that endogenously expressed TRAIL is apparently not able to trigger apoptosis, regardless of differentiation (FIGURES 2A and 2D).

\section{Induction of apoptosis by TRAIL activates executioner caspase-3}

As the morphological analysis (FIGURE 1) suggested that differentiating cells were less sensitive to TRAIL, we investigated whether keratinocyte differentiation influences the apoptotic response as measured by caspase- 3 activation. It appears that undifferentiated keratinocytes are more sensitive to TRAIL-induced apoptosis than those committed to differ- 


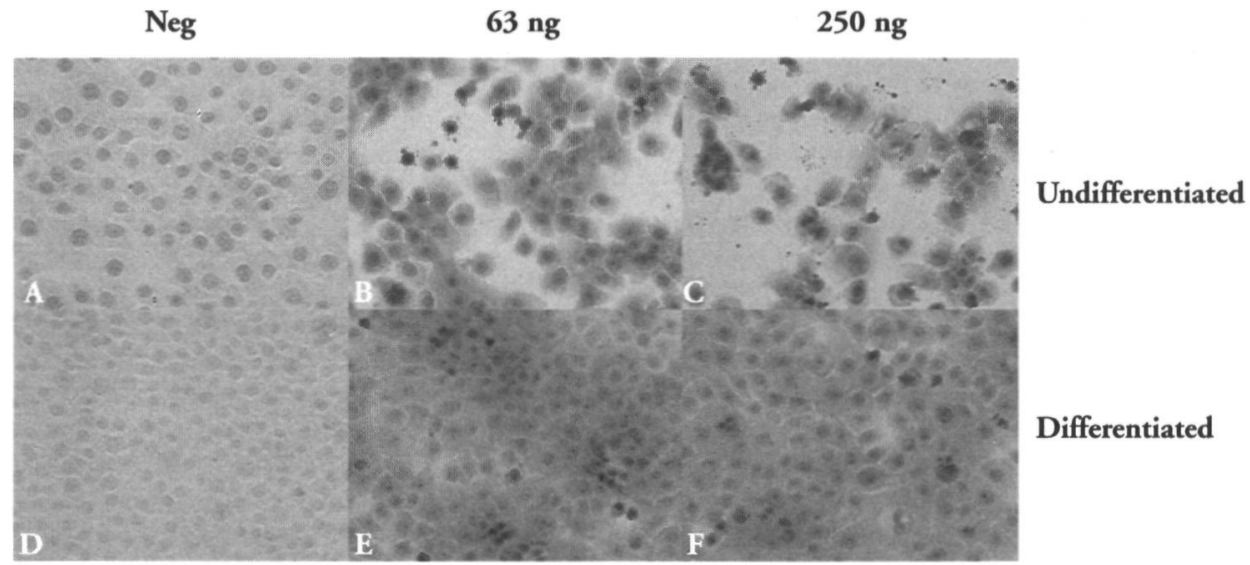

FIGURE 2 TRAIL causes apoptosis in cultured human epidermal keratinocytes. Keratinocytes were either stimulated directly with 0 (negative control), $63 \mathrm{ng} / \mathrm{ml}$ (B), and $250 \mathrm{ng} / \mathrm{ml}$ TRAIL (C), or first differentiated for 24 hrs before stimulation 0 (negative control) with $63 \mathrm{ng} / \mathrm{ml}$ (E) and $250 \mathrm{ng} / \mathrm{ml}$ TRAIL (F). Negative controls were either undifferentiated (A) and differentiated for 24 hrs (D). Cells were stained with haematoxylin to visualize nuclei, and counterstained with eosin. Apoptotic cells are characterized by nuclear condensation and cellular shrinkage. Neg: negative control; undiff: undifferentiated; diff: differentiating. See last pages for colour image of this figure.

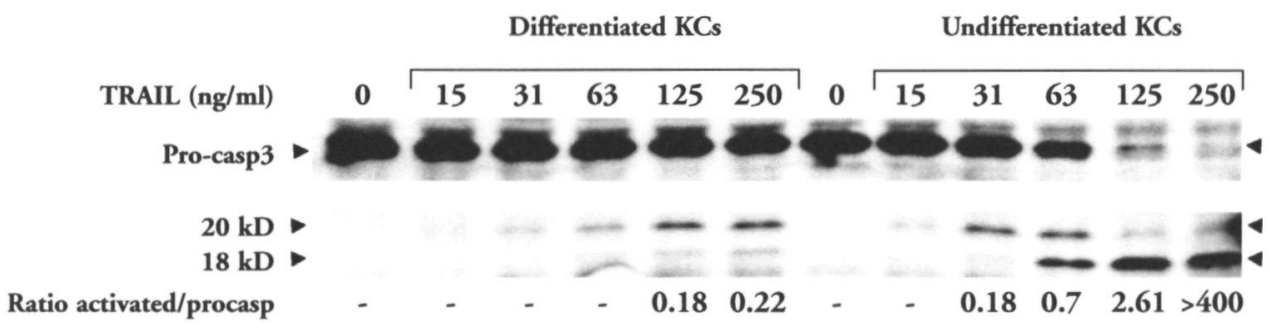

FIGURE 3 Human caspase-3 is activated by TRAIL to a much higher degree in undifferentiated cultured human keratinocytes. Undifferentiated (right side) and differentiated (for $24 \mathrm{hrs,} \mathrm{left} \mathrm{side)} \mathrm{cells} \mathrm{were} \mathrm{incubated} \mathrm{with} 0$ (negative control), 15, 31, 63, 125 or $250 \mathrm{ng} / \mathrm{ml}$ TRAIL, and harvested 3 hours later in Laemmli reducing sample buffer. Bottom: the ratio of activated (18 kDa and $20 \mathrm{kDa}$ products) caspase- 3 to procaspase (bottom) as determined by digital densitometric analysis.

entiation for $24 \mathrm{hrs}$ (FIGURE 3). Furthermore, the band representing the $18 \mathrm{kDa}$ subunit of activated caspase- 3 is almost absent in differentiating keratinocytes, and there is still a considerable amount of unprocessed, inactive caspase present even at the highest concentration of TRAIL used. Indeed, digital densitometric analysis revealed that TRAIL activated caspase-3 to a spectacular, much higher degree in undifferentiated cells as the ratio of activated caspase (18 and $20 \mathrm{kDa}$ bands) to procaspase was more than 400 times higher in in these cells at $250 \mathrm{ng} / \mathrm{ml}$ TRAIL. At $125 \mathrm{ng} / \mathrm{ml}$ TRAIL, this ratio was still a respectable 15 times higher in undifferentiated keratinocytes (FIGURE 3, bottom). Taken together, these data indicate that TRAIL-induced apoptosis is incomplete in differentiating kera- 
FIGURE 4 Human caspase- 8 is rapidly activated by TRAIL in undifferentiated cultured human keratinocytes. Undifferentiated (left side) and differentiated (for $24 \mathrm{hrs,} \mathrm{right} \mathrm{side)} \mathrm{cells} \mathrm{were}$ incubated with 0 (negative control), 63 or $250 \mathrm{ng} / \mathrm{ml}$ TRAIL, and harvested $90 \mathrm{~min}$ later in Laemmli reducing sample buffer. Samples were run on a $12 \%$ polyacrylamide gel, and blotted onto a PVDF membrane. Caspase- 8 was detected with a mouse monoclonal antibody against the active $18 \mathrm{kDa}$ subunit of caspase-8, which also recognizes the active procaspase- 8 and an intermediate of $41 \mathrm{kDa}$.

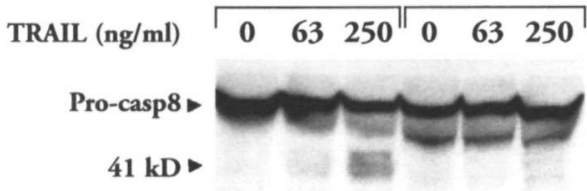

$18 \mathrm{kD}$

tinocytes, and that undifferentiated keratinocytes are extremely sensitive to TRAILinduced apoptosis.

\section{Apoptosis is induced through proximal caspase-8}

It has recently been shown that TRAIL-induced apoptosis through TRAIL-R2 requires the recruitment of Fas-associated death domain containing protein (FADD) and caspase- 8 to the death-inducing signalling complex (DISC), which is associated intracellularly with TRAIL-R2 ${ }^{33-35}$. Upon binding of TRAIL to TRAIL-R2, it is believed that conformational changes in the DISC induce proteolytic activation of caspase- $8^{30,36,37}$. In order to verify that apoptosis is indeed mediated through a receptor and DISC, keratinocytes were grown to confluence, and either directly stimulated with TRAIL, or differentiated for $24 \mathrm{hrs}$ before stimulation. Cells were harvested 90 min after stimulation ${ }^{21}$ in reducing protein sample buffer and subjected to Western blot analysis. Caspase- 8 was identified with a mouse monoclonal antibody which recognizes both inactive procaspase- 8 of $55 \mathrm{kDa}$, the intermediate cleavage product of $41 \mathrm{kDa}$ and the p18 subunit of activated caspase-8. As can be seen in FIGURE 4, caspase- 8 activation is readily induced by TRAIL in undifferentiated keratinocytes at concentrations as low as $63 \mathrm{ng} / \mathrm{ml}$ TRAIL, whereas only the highest concentration of $250 \mathrm{ng} / \mathrm{ml}$ TRAIL was able to activate caspase- 8 in cells that had differentiated for $24 \mathrm{hrs}$ (FIGURE 4), albeit at an almost undetectable level. TRAIL-induced apoptosis in keratinocytes is therefore mediated through one of its receptors TRAIL-R1 or TRAIL-R2, and this activation is both dependent on TRAIL concentration and the differentiation status of the keratinocyte culture.

\section{DNA fragmentation is not induced in keratinocytes during apoptosis}

In addition to the morphological and and biochemical evidence for TRAIL-induced apoptosis, another hallmark, internucleosomal DNA fragmentation ${ }^{29.30}$, was also investigated. Activation of DFF40 during apoptosis leads to an internucleosomal digestion pattern of genomic DNA that appears as fragments of (multiples of) $180 \mathrm{bp}$ on an agarose gel ${ }^{26,28}$. However, when analyzed by agarose gel electroforesis, typical DNA fragmentation could not be detected in apoptotic keratinocytes (inset, FIGURE 5D). Rather, a smear instead of 


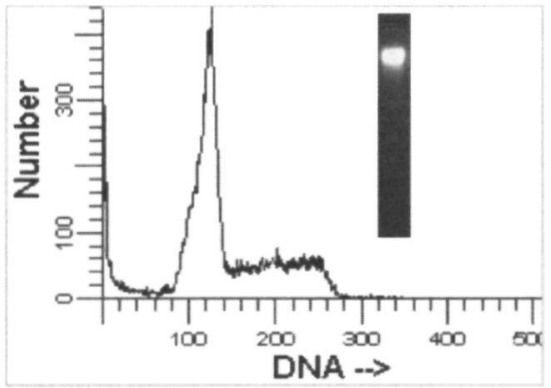

B

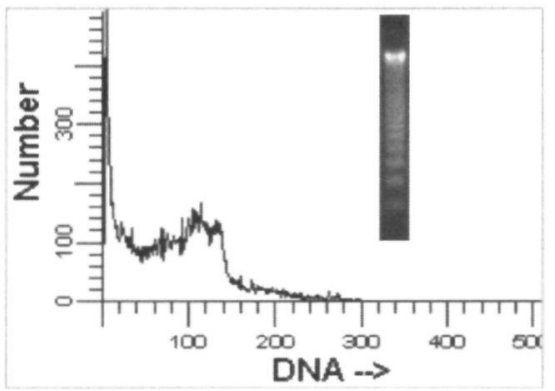

C

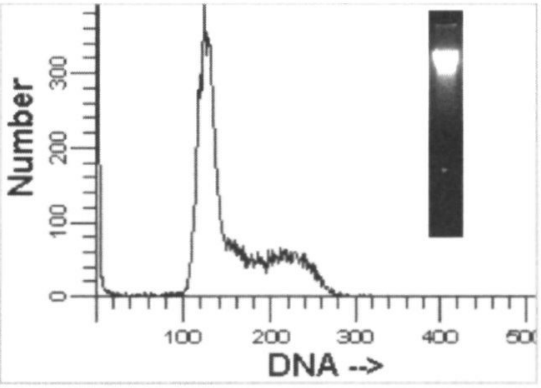

D

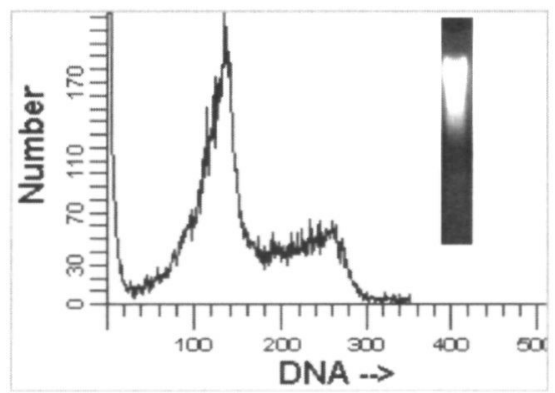

FIGURE 5 DNA fragmentation was investigated in HL60 cells and keratinocytes by means of agarose gel electroforesis (insets) and propidium iodide staining, followed by flowcytometric analysis. Cells were stimulated with $250 \mathrm{ng} / \mathrm{ml}$ TRAIL for 3 hrs. A) HL60 cells, unstimulated (negative control); B) HL60 cells, stimulated; C) undifferentiated keratinocytes, unstimulated; D) undifferentiated keratinocytes, stimulated. Note the absence of fragmentation in keratinocytes.

distinct fragments of degraded genomic DNA appeared. As a control, HL60 cells were also included in the experiment, and these cells readily show DNA fragmentation 3 hrs after TRAIL stimulation (inset, FIGURE 5B). Flow-cytometric analysis of apoptotic keratinocytes, either by propidium iodide staining (FIGURE 5D) or TUNEL (not shown), did not reveal typical DNA fragmentation, whereas once again HL60 cells readily underwent fragmentation (FIGURE 5B). To our surprise, the G1 peak did not tend to disappear in keratinocytes that had been treated with $250 \mathrm{ng} / \mathrm{ml}$ of TRAIL, suggesting that the apparent total cellular content of DNA does not or slowly change in apoptotic keratinocytes. Non-stimulated cells served as negative controls and did not show fragmentation in either HL60 cells (FIGURE 5A) or keratinocytes (FIGURE 5C). Experiments with the spontaneously transformed keratinocyte cell line $\mathrm{HaCaT}$ showed similar results on both agarose gel and with flowcytometric analysis (data not shown), and the response was comparable with that of undifferentiated keratinocytes.

\section{DFF40 is not expressed in keratinocytes and human epidermis}

As DFF40 is the prime effector DNA fragmentation in apoptosis, we investigated whether the expression levels of DFF40 in keratinocytes could explain the lack of DNA fragmentation in these cells. We performed a semi-quantitative RT-PCR on total RNA isolated from cultured keratinocytes, HL60 cells and RNA from purified normal, unaffected and 
FIGURE 6 DFF40 is hardly expressed in human keratinocytes, normal and diseased epidermis as opposed to the promyelocytic leukemia cell line HL60, as assessed by means of RT-PCR. Lane 1, cultured keratinocytes, 24 hrs differentiated; lane 2, HL60 cells; lane 3, psoriatic epidermis, involved; lane 4, uninvolved skin from psoriasis patient; lane 5, normal human epidermis; lane 6 , negative control, no template. An RT-PCR with $\beta$-Actin served as an internal control.

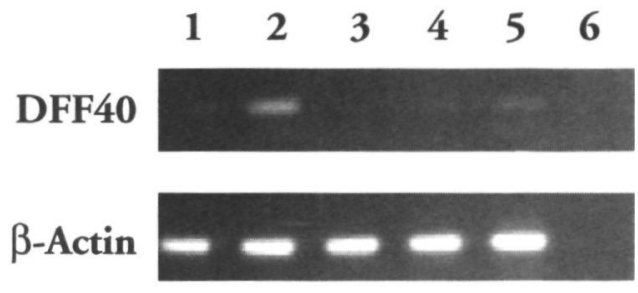

psoriatic epidermis. A PCR with $\beta$-actin primers served as a positive control. As shown in Figure 6, DFF40 is expressed at detectable levels in HL60 cells (lane 2), but not in keratinocytes, and could hardly be detected in human epidermis (lanes 1 and 5 respectively). Interestingly, expression is also very low in affected and unaffected epidermis from a psoriasis patient (lanes 3 and 4, respectively) indicating that DFF40 is apparently not highly expressed in the leukocyte infiltrate that usually is associated with psoriasis.

\section{Discussion}

We have previously shown, by means of SAGE, that cultured keratinocytes express various mediators of apoptosis, irrespective of stimulation with TNF- $\alpha$. TRAIL, a TNF family member, was found to be expressed at moderate levels (TABLE 1) and a role for this cytokine in keratinocyte homeostasis and differentiation, if any, has yet to be established. Its expression has been confirmed at the mRNA level by means of RT-PCR, while others have shown that it is also expressed in cultured keratinocytes at the protein level ${ }^{22}$. In this study, we show both morphologically and biochemically that the induction of apoptosis by TRAIL is dependent on TRAIL concentration and the differentiation status of keratinocytes, using a previously described submerged culture system that allows terminal differentiation ${ }^{24}$. Keratinocytes show nuclear condensation and cellular shrinkage within 3 hours after addition of TRAIL to the medium, albeit to a much lesser extend when cells have differentiated for $24 \mathrm{hrs}$. It is shown that both caspase- 8 and caspase- 3 are activated in keratinocytes upon exposure to TRAIL, indicating that TRAIL acts through one of its two death receptors, TRAIL-R1 or TRAIL-R2, and the DISC, and that the effects seen in culture are not due to necrosis. Internucleosomal DNA fragmentation could not be detected in keratinocytes, neither by agarose gel electroforesis nor by flow cytometric analysis. By means of RT-PCR it is shown that DFF40, the prime effector of this phenomenon, is not expressed in human keratinocytes.

The culture model that we used provides the opportunity to compare the responses of undifferentiated and differentiating keratinocytes. The fact that there is still considerable apoptosis in differentiating cultures probably reflects the proportion of cells that are still proliferating after being switched to medium without growth factors. Although studies have been performed in the past where the effect of TRAIL on primary cultured keratinocytes was found to be mild or absent, it should be noted that these studies did not take into account the state of differentiation of keratinocytes. Leverkus et al. ${ }^{21}$ have shown that resistance to apoptosis is mediated through the apotosis inhibitor FADD-like inhibitory protein (cFLIP), but the same study does not rule out that cFLIP expression is lower or absent in undifferentiated primary keratinocytes. Our SAGE studies indicate that cFLIP is 
expressed in differentıated keratınocytes (TABLE 1) albeit at low levels In another study, Kothny-Wilkes et al ${ }^{22}$ claim that primary keratınocytes are insensitive to TRAIL, which we found not to be the case The fact that undifferentiated keratınocytes are far more sensitive to TRAIL, and respond by undergoing massive apoptosis as opposed to differentiatIng keratınocytes, suggests that culture conditions have an enormous impact on the degree of apoptosis in these cells It has recently become apparent that cultured primary keratunocytes are relatively resistant to UV-induced apoptosis when they have been grown to confluence or have undergone senescence, whereas the transformed keratinocyte cell line $\mathrm{HaCaT}$ is much more sensitive ${ }^{\text {tH }}$ It appears that the susceptibility of $\mathrm{HaCaTs}$ can at least in part be ascribed to the absence of the tumor suppressor p16 (due to promoter methylation) and dysfunctional NF- $\kappa \mathrm{B}$, which in its functional state is implicated in cell survival pathways Interestingly, the same study showed that subconfluent, undifferentiated keratinocytes are much more prone to apoptosis, but that death resistance does not require early differentiation It has also been shown that NF- $\mathrm{KB}$ is responsible for the apoptosisresistant phenotype of keratınocytes ${ }^{19}$ TRAIL-Induced apoptosis in keratınocytes apparently does not depend in the same way on the state of differentiation as opposed to UVinduced apoptosis, which may also reflect different death pathways First, confluent, undifferentiated keratınocytes still underwent massive apoptosis and second, only a short period of differentiation of $3 \mathrm{hrs}$ already caused considerable resistance to TRAIL-induced death (data not shown) This suggests that the presence of a fully differentiated phenotype is not required to confer resistance to apoptosis, but that the commitment to terminal differentiation is sufficient That different intrinsic death pathways in keratinocytes exist is suggested by the finding that interleukin I (IL-1) can inhibit TRAIL- and Fas-induced apoptosis in the transformed keratınocytes cell line $\mathrm{HaCaT}$, but not $\mathrm{UV}$-induced apoptosis ${ }^{40}$ The inhibitory effect of IL-1 involves the activation of NF- $\kappa B$, but it even enhances the apoptotic effect of UV irradiation How these pathways converge or diverge is yet to be determined, as also TNF- $\alpha$ is released during UV-induced apoprosis, and also may add to massive cell deach

TRAIL is also expressed in human epidermis at the mRNA level, posing questions about its function in epidermal homeostasis As the epidermis is at the interface of the environment and the organism, and is constantly exposed to environmental insult, it may serve a as an apoptotic stımulus to neighbouring cells whenever they are subject to processes that inflict irreversible damage It thus provides an efficient means to kill unwanted cells (damage control) Recently, however, it has become apparent that TRAIL can be involved in reverse signallıng, where signals are not transduced through the receptor but through the membrane anchored ligand upon ligation This has been demonstrated for activated $T$ cells, where signalling though TRAIL enhances proliferation and IFN- $\gamma$ production through a $\mathrm{p}^{38}$ /MAPK dependent pathway ${ }^{41}$ A role for TNF family members in skın development and homeostasis has been suggested by knockung out TNF- $\alpha$ converting enzyme (TACE) in mice, a metalloprotease that sheds TNF- $\alpha$ and TGF- $\alpha$ from its membrane-bound terminus, which leads to aberrant epidermal development, corneal inflammation and perinatal death ${ }^{42}$ Furthermore, a role for the TNF family members ectodysplasın (EDA) and its receprors EDAR and X-lınked EDAR (XEDAR) in mammalıan skın development and homeostasis is evident from the fact that debilitating mutations in any of these genes lead to skin abnormalities, among others Based on these findings, it is tempting to speculate that TRAIL, although expressed in many different tissues, also may play a role in skin development or homeostasis The established expression of TRAIL-R1, $-R 2$ and $-R 4^{21}$ also adds fuel to the idea that this cytokıne may play a more complex role than just being an inducer of apoptosis in the skın 
One of the key features of termınal keratınocyte differentiation is that cells eventually will undergo programmed cell death, which takes days to complete as opposed to hours in response to TRAIL Interestingly, this normal differentiation process is not associated with internucleosomal DNA fragmentation RT-PCR experiments (FIGURE 6) show that its prime effector DFF40 is not or hardly expressed in keratınocytes and epidermis at the mRNA level To our knowledge, this is the first time that the expression of this molecule has been investigated in keratinocytes This finding could well explann the absence of DNA fragmentation during programmed cell death as a result of differentiation It is known that apoptosis with typical DNA fragmentation does occur in cells of the keratinocyte lineage in hair follicles, as has been shown in the past by agarose gel electroforesis and TUNEL staining ${ }^{43}$ There is additional evidence that epidermal stem cells with high proliferative capacity reside in the hair follicle ${ }^{454}$ "These may for reasons of safery be much more sensitive to apoptotis stımul, and thus may in fact express DFF40 to expedite apoptosis in case of toxic or carcinogenic insult, and may also explain why typical DNA fragmentation is only seen in the hair follicle Furthermore, the very low level of DFF40 expression seen in epidermis and cultured keratınocytes may reflect the presence of cells derived from hair follicles

In this study we have demonstrated that TRAIL can induce apotosis in human keratinocytes through its receptors Further research is needed to elucidate its role in epidermal development and homeostasis The fact that DFF40 is not expressed in keratinocytes, together with dimınıshed sensitivity of differentiatıng keratınocytes to TRAIL, suggests that suicidal parhways during terminal differentiation are distınct from typical apoptosis seen in response to cytotoxic stımuli, and further supports previous findings that terminal differentiation involves other pathways ' 7 Little is known about the machinery that leads to cellular decay during keratinocyte differentiation, and future research is needed to elucidate and identify relevant pathways and cellular machineries involved in this process 
1. Fuchs E. Epidermal differentiation and keratın gene expression.

J Cell Scı Suppl 1993;17:197-208.

2. Watt FM. Terminal differentiation of epidermal keratinocytes. Curr Opın Cell Bıol 1989; 1 (6):1 107-15.

3. Eckert RL, Crish JF, Banks EB, Welter JF. The epidermis: genes on - genes off. J Invest Dermatol 1997;109(4):501-9.

4. Eckert RL, Crish JF, Robinson NA. The epidermal keratinocyte as a model for the study of gene regulation and cell differentiation Physiol Rev 1997;77(2).397-424.

5. Gandarillas A, Goldsmith LA, Gschmeissner S, Leigh IM, Watt FM. Evidence that apoptosis and terminal differentiation of epidermal keratınocytes are distinct processes

Exp Dermatol 1999;8(1):71-9

6. Eckhart L, Declercq W. Ban J, Rendl M. Lengauer B, Mayer C, et al.

Terminal differentiation of human keratınocytes and stratum corneum formation ss associated with caspase-14 acturation.

J Invest Dermatol 2000,115(6).1148-51.

7 Lippens S, Kockx M, Knaapen M, Mortier $L$, Polakowska R, Verheyen A, et al. Epidermal differentiation does not involve the pro-apopronic executioner caspases, but is associated with caspase-14 induction and processing Cell Death Differ 2000;7(12):1218-1224.

8. Kulms D, Poppelmann B, Yarosh D, Luger TA, Krutmann J, Schwarz T Nuclear and cell membrane effects contribute independently to the induction of apoptosis in human cells exposed to UVB radiation. Proc Nat Acad Seı U S A 1999;96(14):7974-9

9. Kulms D, Schwarz T. Molecular mechanisms of UV-induced apoptosis Photodermatol Photoimmunol Photomed 2000,16(5) 195-201.

10 Pfundr R, van $V_{1}$ jmen-Willems I, Bergers $M$, Wingens $M$, Cloin W, Schalkwı)k J. In situ demonstration of phosphorylated c-jun and p38 MAP kınase in epidermal keratınocytes following ultraviolet B irradiation of human skin J Pathol 2001;193(2):248-55

11. Liu ZG, Baskaran R, Lea-Chou ET, Wood LD, Chen $Y$, Karın M, et al. Three distunct sıgnalling responses by murine fibroblasts to genotoxic stress Nature 1996,384(6606) 273-6.
12. Ziegler A, Jonason AS, Leffell DJ, Sumon JA, Sharma HW, Kimmelman J, et al. Sunburn and $\mathrm{p} 53$ in the onset of skin ancer Nature 1994;372(6508):773-6.

13. Aragane $Y$, Kulms D, Metze D, Wilkes G, Poppelmann B, Luger TA, et al. Ultraviolet light Induces apoptosis va direct activation of CD95 (Fas/APO-1) independently of its ligand CD95L. J Cell Bıl 1998;140(1).171-82.

14. Sheıkh MS, Antınore MJ, Huang Y, Fornace AJ. Ultravolet-ırradiation-induced apoptosis is mediated via ligand independent activation of tumor necrosis factor receptor 1.

Oncogene 1998,17(20) 2555-63.

15. Leverkus $M$, Yaar $M$, Gilchrest $B A$. Fas/Fas ligand interaction contributes to UV-induced apoprosis In human keratınocytes

Exp Cell Res 1997;232(2):255-62.

16. Viard I, Wehrlı P, Bullani R, Schneider P, Holler N, Salomon D, et al. Inhibition of toxic epidermal necrolysis by blockade of CD95 with human intravenous immunoglobulin. Science 1998;282(5388)-490-3

17. Tradl C, Sebastıanı S, Albanesı C, Merk HF, Puddu P, Girolomon G, et al. Disparate cytotoxic activicy of nickel-specific CD8 + and CD4+ T cell subsets agaunst keratınocytes J Immunol 2000;165(6):3058-64

18. Trautmann $A$, Akdis $M$, Kleemann $D$, Alznauer F, Simon HU, Graeve T, et al T cell-mediated Fas-ınduced keratınocyte apoptosis plays a key pathogenetic role in eczematous dermatitıs. J Clin Invest 2000;106(1) 25-35

19. Jansen $B J H$, van Russen $F$, de Jongh $G$, Zeeuwen PLJM, Schalkwık J Serial analysis of gene expression in differentiated cultures of human epidermal keratmocytes J Invest Dermatol 2001,116(1).12-22

20 Jo M, Kum TH, Seol DW, Esplen JE, Dorko K, Billiar TR, et al. Apoptosis induced in normal human hepatocytes by tumor necrosis factor- related apoptosis-inducing ligand Nat Med 2000;6(5) $564-7$ 
21 Leverkus $M$, Neumann $M$, Mengling $T$, Rauch CT, Brocker EB, Krammer PH, et al. Regulation of rumor necrosis factor-related apoptosis-inducıng ligand sensıtıvicy in prımary and transformed human keratinocyes.

Cancer Res 2000;60(3).553-9.

22. Kothny-Wilkes G, Kulms D, Poppelmann B, Luger TA, Kubin M, Schwarz T. Interleukin-1 protects transformed keratinocytes from tumor necrosis factor-related apoptosis-ınducing ligand J Bıol Chem 1998;273(44):29247-53.

23. Basule JR, Zaeny V, Munger $K$. The cyrokunes tumor necrosis factor-alpha (tnf-alpha) and inf-related apoptosis-1nducing ligand differentially modulare proliferation and apoptonic pachways in human keratınocyres expressing the human papillomavirus-16 e7 oncoprotein. J Bıol Chem 2001;276(25):22522-8.

24 Van Russen F, de Jongh GJ, Zeeuwen PL, Van Erp PE, Madsen P, Schalkwık J. Induction of normal and psoriatic phenorypes in submerged kerarınocyte cultures.

J Cell Physiol 1996; 168(2)·442-52

25. Pfundt $R$, Wingens $M$, Bergers $M, Z$ zweers $M$, Frenken M, Schalkwijk J TNF-alpha and serum induce SKALP/elafin gene expression in human keratınocyres by a p38 MAP kınase-dependent pathway. Arch Dermatol Res 2000;292(4) $180-7$

26. Luน X, Zou H, Slaughter C, Wang X. DFF, a heterodimeric protein that functions downstream of caspase- 3 to trigger DNA fragmentation during apoptosis. Cell 1997;89(2) $175-84$

27 Enari M, Sakahıra H, Yokoyama H, Okewa K, Iwamatsu A, Nagata $S$ A caspase-activated DNase that degrades DNA durıng apoptosis, and its inhıbitor ICAD. Nature 1998;391(6662)·43-50 Sakahira H, Enarı M, Nagata S. Cleavage of CAD inhibitor in CAD activation and DNA degradation during apoptosis. Nature 1998;391(6662)·96-9.

29 Wyllie AH, Kerr JF, Currie AR. Cell death: the significance of apoptosis Int Rev Cytol 1980;68.251-306

30 Hengarner MO The biochemistry of apoptosis Narure 2000;407(6805) 770-6.

31 Velculescu VE, Zhang L, Vogelstein B, Kinzler KW Serial analysis of gene expression Science 1995,270(5235) 484-7.
32. Sambrook J. Fritsch EF, Manıatis T Molecular cloning . a laboratory manual. 2nd ed. Cold Spring Harbor, N Y : Cold Sprıng Harbor Laboratory, 1989.

33. Sprick MR, Weigand MA, Rieser E, Rauch CT, Juo P, Blenis J, et al FADD/MORT1 and caspase- 8 are recruted to TRALL receptors 1 and 2 and are essential for apoptosis mediated by TRAIL receptor 2 Immunity 2000;12(6).599-609.

34. Kuschicel FC, Lawrence DA, Chuntharapad A, Schow P, Kim KJ, Ashkenazı A Apo2L/TRAILdependent recruttment of endogenous FADD and caspase-8 to death receptors 4 and 5 . Immunity 2000;12(6):611-20.

35. Bodmer JL, Holler N, Reynard S, Vinciguerra P, Schneider P, Juo P, et al. TRAIL receptor-2 signals apoptosis through FADD and caspase-8 Nat Cell Bıol 2000,2(4) 241-3.

36. Salvesen GS, Duxit VM Caspase activation the induced-proxumity model. Proc Natl Acad Scı US A 1999,96(20).10964-7.

37 Muzıo M, Stockwell BR, Stennicke HR, Salvesen GS, Dixıt VM An induced proxımıry model for caspase- 8 activation J Bıol Chem 1998;273(5).2926-30

38 Chaturvedı V, Qın JZ, Denning MF, Choubey D, Diaz MO, Nickoloff BJ. Apoptosis in prolıferatıng senescent, and immortalized keratinocytes J Biol Chem 1999;274(33).23358-67.

39 Qın JZ, Chaturvedı V, Denning MF, Choubey D, Diaz MO, Nickoloff BJ Role of NF-kappaB in the apoptotic-resistant phenotype of keratinocytes J Bıl Chem 1999;274(53) 37957-64.

40 Korhny-Wilkes G, Kulms D, Luger TA, Kubin M, Schwar T. Interleukın-1 protects transformed keraunocyres from rumor necrosis factor-related apoptosis-inducing ligand-and CD9S-induced apoptosis but not from ultraviolet radiation-induced apoptosis J Biol Chem 1999;274(41) 28916-21

41. Chou AH, Tsaı HF, Lin LL, Hsieh SL, Hsu PI, Hsu PN Enhanced Proliferation and Increased IFN-gamma Production in T Cells by Signal Transduced Through TNF-Relared ApoptosisInducing Ligand J Immunol 2001;167(3).1347-1352

42. Peschon JJ, Slack JL, Reddy P, Stocking KL, Sunnarborg SW, Lee DC, et al An essential role for ectodoman shedding in mammalian development. Science 1998;282(5392):1281-4 
43 Matsuo K, Morı O, Hashımoto T. Apoptosıs in murıne har follicles durıng catagen regression Arch Dermatol Res 1998;290(3)·133-6.

44. Lindner G, Borchkarev VA, Botchkareva NV, Ling G, van der Veen C, Paus R. Analysis of apoptosis durıng hair follicle regression (catagen). An J Pathol 1997;151(6)-1601-17

45. Taylor G, Lehrer MS, Jensen PJ, Sun TT, Lavker RM. Involvement of follicular stern cells in forming not only the follicle but also the epidermıs. Cell 2000,102(4):451-61.

46. Oshıma H, Rochat A, Kedzıa C, Kobayashı K, Barrandon Y. Morphogenesıs and renewal of hair follıcles from adult multıpotent stem cells. Cell 2001;104(2):233-45. 


Using Serial Analysis of Gene Expression on cultured human keratinocytes we found high expression levels of genes putatively involved in host protection and defense, such as proteinase inhibitors and antimicrobial proteins. One of these expressed genes was the recently discovered cysteine proteinase inhibitor cystatin $\mathrm{M} / \mathrm{E}$ that has not been characterized so far at the protein level with respect to tissue distribution and additional biologic properties. Here we report that cystatin $\mathrm{M} / \mathrm{E}$ has a tissue-specific expression pattern in which high expression levels are restricted to the stratum granulosum of normal human skin, the stratum granulosum/spinosum of psoriatic skin, and the secretory coils of eccrine swear glands. Low expression levels were found in the nasal cavity. The presence of cystatin $M / E$ in skin and the lack of expression in a variety of other tissues was verified both at the protein level by immunohistochemistry or Western blotting, and at the mRNA level by reverse transcriptase polymerase chain reaction or Northern blotting. Using biotinylated hexapeptide probes we found that cystatin $\mathrm{M} / \mathrm{E}$ is an efficient substrate for tissue type transglutaminase and for transglutaminases extracted from stratum corneum, and that it acts as an acyl acceptor but not as an acyl donor. Western blot analysis showed that recombinant cystatin $\mathrm{M} / \mathrm{E}$ could be cross-linked to a variety of proteins extracted from stratum corneum. In vitro, we found that cystatin $\mathrm{M} / \mathrm{E}$ expression in cultured keratinocytes is upregulated at the mRNA and protein level, upon induction of differentiation. We demonstrate that cystatin $\mathrm{M} / \mathrm{E}$, which has a putative signal peptide, is indeed a secreted protein and is found in vitro in culture supernatant and in vivo in human sweat by enzyme-linked immunosorbent assay or Western blotting. Cystatin M/E showed moderate inhibition of cathepsin B but was not active against cathepsin $C$. We speculate that cystatin $M / E$ is unlikely to be a physiologically relevant inhibitor of intracellular lysosomal cysteine proteinases but rather functions as an inhibitor of self and nonself cysteine proteinases that remain to be identified. 
Cystatins are natural and specific inhibitors of endogenous mammalian lysosomal cysteine proteinases, such as cathepsins $\mathrm{B}, \mathrm{L}, \mathrm{H}$, and $\mathrm{S}^{12}$, and exogenous microbial cysteine proteinases '. Several studies have indicated that cystatins provide important regulatory and protective functions against uncontrolled proteolysis by cysteine proteinases from host, bacterial, and viral origin 4 . A disturbed balance between proteinases and their inhibitors can lead to irreversible damage as in chronic inflammatory reactions ${ }^{5}$ and tumor metastasis $^{6}$. In addition to their proteinase inhibitory activity, some of the cystatins ( $C$ and $S$ ) were shown to have antimicrobial activity against bacteria ${ }^{78}$ and viruses ${ }^{910}$. Cystatins are members of a superfamily of evolutionary related proteins and can be divided into three major families ": family 1 cystatins A and B (or steffins A and B), family 2 cystatins (C, D, S, $S N$, and $S A$ ), and the kininogens, which belong to family 3 cystatins. A new member of the human cystatin superfamily, named cystatin $M$, was recently identified and characterized ${ }^{12}$. The gene was identified by differential display, comparing mRNAs from primary and metastatic breast tumor cells, and was found to be downregulated in metastatic cells. The same cystatin was independently found by expressed sequence tag sequencing in epithelial-cell-derived cDNA libraries and reported as cystatin $E^{13}$. Cystatin $M / E$ is a 14 $\mathrm{kDa}$ protein that shares a 35\% homology with the human family 2 cystatins, has similar overall structures, such as signal peptide and two intrachain disulfide bonds, but possesses the unusual characteristic of being a glycoprotein. Cystatin $\mathrm{M} / \mathrm{E}$ proved to be a potent inhibitor of papain and cathepsin B ${ }^{12}{ }^{13}$, although specific physiologic functions or target molecules have not been reported so far. Cystatin $\mathrm{M} / \mathrm{E}$ was reported to have a broad tissue distribution at the mRNA level, although the reports of $\mathrm{Ni}$ et al. and Sotiropoulou et al. gave conflicting results. No tissue localization studies at the protein level have been reported to date.

Epithelial tissues serve as a first line of defense between the host and the environment. Disturbance of this barrier can lead to the invasion of microbial pathogens and subsequent inflammation. Previous studies have shown that epithelia that are subjected to continuous microbial stress or inflammatory stimuli (e.g., oral epithelia, trachea, skin) express several proteins that provide protection against microbial pathogens and excessive proteolysis by endogenous and exogenous proteinases. These proteins have been assigned as a key component of the innate immune system ${ }^{14}$ is, a system that can be triggered by infection and protects the host organism against invading microorganisms ${ }^{16}$. Recently, several proteins that are involved in protection against tissue damage were found to be expressed in human skin in response to inflammatory events. These proteins include two well-characterized serine proteinase inhibitors with antimicrobial properties, secretory leukocyte proteinase inhibitor (SLPI) ${ }^{17} 19$ and skin-derived antileukoproteinase (SKALP)/elafin ${ }^{20}$, a member of the trappin gene family ${ }^{21}{ }^{22}$. Both proteins are originally described as inhibitors of polymorphonuclear leukocyte derived enzymes, like human neutrophil elastase, that are secreted under inflammatory conditions of the skin (e.g., wound healing, psoriasis) ${ }^{27}{ }^{27}$.

Much of the barrier function of human epidermis against the environment is provided by the cornified cell envelope (CE) ${ }^{2829}$, which is assembled by transglutaminase (TGase) cross-linking of several structural proteins, like small proline-rich proteins, loricrin, cytokeratins, filaggrin, and involucrin ${ }^{30}$. Two epidermal proteinase inhibitors were found to be anchored to structural proteins of the stratum corneum. SKALP/elafin was found in fore- 
skin by direct protein sequencing ${ }^{31}$, and cystatin A, the only member of the cystatin family so far that has been found in human epidermis, was shown to be part of the CE and acts as a TGase substrate ${ }^{32}$.

Recently we have started with the construction of a transcriptome of human epidermis using Serial Analysis of Gene Expression (SAGE). Using SAGE we have made an extensive expression profile of cultured human keratinocytes, comprising over 25,000 sequenced tags ${ }^{33}$. From this analysis it was clear that genes involved in host protection and host defense (proteinase inhibitors and antimicrobial proteins) were expressed at high levels. Cystatin $\mathrm{M} / \mathrm{E}$, not previously known to be expressed by adult human keratinocytes, was found at considerable levels in these analyses. In this paper we report the skin-specific expression of cystatin $\mathrm{M} / \mathrm{E}$, and its induction by serum in vitro using cultured human keratinocytes. We demonstrate that cystatin $\mathrm{M} / \mathrm{E}$ is a secreted protein and, in addition to its reported antiproteinase activity, has at least one additional biologic property by acting as an acyl acceptor in TGasemediated reactions, thereby becoming a structural part of the $\mathrm{CE}$.

\section{Materials \& methods}

\section{Keratinocyte culture}

Human keratinocytes were obtained from shave biopsies of adult epidermis (lower back) and were primary cultured according to the Rheinwald-Green system ${ }^{34}$. First passage cells were seeded in keratinocyte growth medium (KGM; BioWhittaker, Walkersville, MD) as described by Van Ruissen et al. ${ }^{35}$. Differentiation of keratinocytes was induced by switching confluent kerarinocyte cultures for $72 \mathrm{~h}$ to KGM supplemented with $5 \%$ fetal bovine serum (FBS).

\section{Cloning of cystatin $\mathrm{M} / \mathrm{E}$ in baculovirus}

Based on the cDNA sequence of cystatin $\mathrm{M} / \mathrm{E}^{12}$ we designed two oligonucleotide primers that could amplify a partial cDNA, encoding amino acid residue Pro ${ }^{23}$ to the stop codon at position 150 (cystatin M/E forward primer, 5'-GAAGATCTCCACGCGATGCCCG-3'; cystatin M/E reverse primer, 5'-CGGAATTCTCACATCTGCACACAG-3'), excluding the amino acid residues corresponding to the hydrophobic signal peptide ${ }^{12}$. Polymerase chain reactions (PCR) were carried out using a DNA thermal cycler (PTC-200, Biozym, Landgraaf, The Netherlands) in $25 \mu \mathrm{l}$ mixtures. The following buffer conditions were used: $10 \mathrm{mM}$ Tris- $\mathrm{HCl}$, pH $9.0,1.5 \mathrm{mM}$ magnesium chloride, $50 \mathrm{mM}$ potassium chloride, $0.1 \%$ Triton X-100, all four dNTPs (each at $200 \mu \mathrm{M}$ ), 1 unit of Taq DNA Polymerase (Promega, Madison, WI), and $20 \mathrm{pmol}$ of each primer. After an initial incubation of $6 \mathrm{~min}$ at $94^{\circ} \mathrm{C}$ amplification was conducted for one cycle of $1 \mathrm{~min}$ at $94^{\circ} \mathrm{C}, 1 \mathrm{~min}$ at $47^{\circ} \mathrm{C}$, and $2 \mathrm{~min}$ at $72^{\circ} \mathrm{C}$, followed by 34 cycles with an annealing temperature of $60^{\circ} \mathrm{C}$. An additional $10 \mathrm{~min}$ at $72^{\circ} \mathrm{C}$ was used for the last cycle. As template for the PCR we used cystatin M cDNA ${ }^{12}$. The amplified fragment was cloned in frame into the $\mathrm{pFastbac-HTb}$ baculovirus expression vector, a component of the Bac-to-Bac Baculovirus Expression System (Life Technologies). After the recombinant $\mathrm{pFastbac-HTb}$ donor plasmid has been determined to be correct, the DNA is transformed into competent DH10Bac Escherichia coli cells for transposition into a baculovirus shuttle vector (bacmid), according to the protocol provided by the manufacturer. High molecular weight mini-prep DNA is prepared from selected E.coli clones con- 
taining the recombinant bacmid. These clones were screened for the presence of the desired sequences, and then used to transfect insect cells.

\section{Production of recombinant baculovirus}

Recombinant bacmid was transfected into Spodoptera frugiperda (SF) cells using Celfectin Reagent (Life Technologies) according to the protocol provided by the manufacturer, followed by infection of insect cells with recombinant baculovirus particles. The infected cells were harvested and lyzed, the cell debris was removed by centrifugation, and the supernatant, which contains the recombinant (His) $6_{6}$-tagged cystatin $\mathrm{M} / \mathrm{E}$ protein, was stored at $4^{\circ} \mathrm{C}$.

\section{Purification of recombinant cystatin M/E}

We purified recombinant cystatin $\mathrm{M} / \mathrm{E}$ with a Tris-based buffer system according to the protocol provided by the manufacturer (Bac-to-Bac Baculovirus Expression System, Life Technologies), with the exception that $\beta$-mercaptoethanol and glycerol were omitted from all buffer solutions. To obtain recombinant cystatin $\mathrm{M} / \mathrm{E}$ without the polyhistidine tag, the baculovirus expressed protein was digested with tobacco etch virus (TEV) proteinase according to the protocol provided by the manufacturer (Life Technologies).

\section{Production and purification of recombinant glutathione S-transferase (GST)-cystatin M/E}

The recombinant plasmid pGEX-2T/cystatin M/E was used to produce and purify recombinant GST-cystatin M/E fusion protein as described previously ${ }^{22}$. To obtain recombinant cystatin M/E without the GST tag, the bacterially expressed fusion protein was digested with thrombin according to the protocol provided by the manufacturer (Sigma).

\section{Polyclonal antibodies}

The purified GST-cystatin M/E fusion protein was used to immunize a New Zealand White rabbit and a Duncan Hartley guinea pig, which was carried out at the Central Animal Laboratory, University of Nijmegen, The Netherlands. Antisera raised against the GST-cystatin M/E fusion protein were purified by affinity chromatography using recombinant fusion protein coupled to CNBr-activated Sepharose 4B (Pharmacia Biotech).

\section{Autopsic material, skin biopsies, and tape stripping}

Autopsic material was obtained from the Department of Pathology, University of Nijmegen, The Netherlands. The following tissues were studied with respect to cystatin $\mathrm{M} / \mathrm{E}$ expression: skin, tongue, gingiva, palatum, pharynx, nasal cavity, sole of the foot, esophagus, ileum, colon, stomach, bronchus, lung, trachea, ureter, kidney, bladder, pancreas, liver, heart, spleen, skeleton muscle, lymph node, aorta, cartilage, mammary gland, and uterus. Biopsies of normal skin and from psoriatic lesions were taken under local anesthesia with a keratome as described by Alkemade et al. ${ }^{3}$.

\section{Immunohistochemistry (IHC)}

Human skin biopsies and autopsic material were processed for IHC as previously described ${ }^{17}$. The sections were subsequently incubated with affiniry-purified polyclonal rabbit anticystatin $\mathrm{M} / \mathrm{E}$ antibodies at a 1:50 dilution followed by $\mathrm{IHC}$ staining as described previously ${ }^{3}$. 
Total RNA from human cultured keratinocytes and human tissues was isolated with RNA extraction solution ${ }^{38}$. Messenger RNA was isolated using the Quickprep Micro mRNA Purification Kit (Pharmacia Biotech), according to the manufacturer's protocol.

\section{Reverse transcriptase PCR (RT-PCR) amplification of the cystatin M/E transcript}

First strand $c D N A$ was generated from $m R N A$ as described previously ${ }^{21}$. The reverse transcriptase reaction products were used for PCR amplification to obtain the cDNA of cystatin $\mathrm{M} / \mathrm{E}$ and the housekeeping gene human acidic ribosomal phosphoprotein P0 (hARP0). We designed oligonucleotide primers that could amplify the cystatin M/E cDNA including the ATG start codon and the TGA stop codon. These oligonucleotide sequences (first sense then antisense) for the cystatin M/E PCR were 5'-TCCGACGGCACTGACGGC-3' and 5'-CCAATGGCCTTCGCCCTCG-3'. The oligonucleotide sequences (first sense then antisense) to generate hARPO cDNA were 5'-ATGTGAAGTCACTGTGCC-3' and 5'-ACCAAATCCCATATCCTC-3'. PCRs were carried out using a DNA thermal cycler (TB1, Biometra, Göttingen, Germany) in $25 \mu \mathrm{l}$ mixtures. The following buffer conditions were used: $10 \mathrm{mM}$ Tris- $\mathrm{HCl}, \mathrm{pH} 9.0,1 \mathrm{mM}$ magnesium chloride, $50 \mathrm{mM}$ potassium chloride, $0.1 \%$ Triton X-100, all four dNTPs (each at $200 \mu \mathrm{M}$ ), 1 unit of Tag DNA Polymerase (Promega), and 20 pmol of each primer. After an initial incubation of $6 \mathrm{~min}$ at $94^{\circ} \mathrm{C}$ amplification was conducted for 35 cycles as follows: 1 min at $94^{\circ} \mathrm{C}, 1 \mathrm{~min}$ at annealing temperature, and $2 \mathrm{~min}$ at $72^{\circ} \mathrm{C}$. An additional $10 \mathrm{~min}$ at $72^{\circ} \mathrm{C}$ was used for the last cycle. Annealing temperatures were $58^{\circ} \mathrm{C}$ when using the cystatin $\mathrm{M} / \mathrm{E}$ primers and $47^{\circ} \mathrm{C}$ for the hARP0 primers. PCR products were analyzed by agarose gel electrophoresis.

\section{Northern blot analysis}

Northern blot analysis was carried out as described by Van Ruissen et al. ${ }^{35}$. Cystatin M/E $\mathrm{cDNA}^{12}$ and hARP0 $\mathrm{cDNA}$ were labeled with $\left[\alpha-{ }^{32} \mathrm{P}\right] \mathrm{dCTP}$ using the Oligolabeling Kit (Pharmacia Biotech) according to the protocol provided by the manufacturer.

Analysis of cystatin M/E inhibitory activity by enzyme assays

Papain and cathepsin B assay

Proteinase inhibitory activity of recombinant cystatin $\mathrm{M} / \mathrm{E}$ was determined by measuring the inhibition of papain (Sigma) and cathepsin B (ICN Pharmaceuticals, Costa Mesa, CA) essentially described by Abrahamson ${ }^{2}$, using the fluorogenic syntheric substrate Z-PheArg-AMC (Sigma). Papain/cathepsin B was titrated in the absence and presence of increasing concentrations of recombinant cystatin $\mathrm{M} / \mathrm{E}$.

Cathepsin C assay

Extracts of normal human skin were tested for cathepsin $\mathrm{C}$ activity by measuring the hydrolysis of fluorogenic substrate H-Gly-Phe-AMC (Bachum, Bubendorf, Switzerland) using a modified protocol ${ }^{30}$. The amount of fluorescence signal produced from the sub- 
strate by skin extract was measured in sodium phosphate buffer $(0.1 \mathrm{M}, \mathrm{pH} 5.5)$ containing $100 \mathrm{mM} \mathrm{NaCl}$ and $2 \mathrm{mM}$ dithiothreitol. Substrate hydrolysis was measured after an incubation of $30 \mathrm{~min}$ at $37^{\circ} \mathrm{C}$. Skin extract (containing cathepsin C) was titrated in the absence and presence of increasing concentrations of recombinant cystatin $\mathrm{M} / \mathrm{E}$.

\section{Enzyme-linked immunosorbent assay (ELISA) for measurement of cystatin $\mathrm{M} / \mathrm{E}$ levels}

Cystatin M/E concentrations were measured in supernatant of cultured keratinocytes and human sweat and nasal mucus, using a sandwich-type ELISA. Microtiter plates (96 flat bottom wells) were coated overnight with purified rabbit anticystatin $M / E$ antiserum (1:1600 dilution in phosphate-buffered saline (PBS)). The incubation steps in this protocol are carried out for $45 \mathrm{~min}$ at $37^{\circ} \mathrm{C}$, and every incubation step in the protocol is followed by a washing step with PBS containing 0.05\% Tween-20 (BioRad, Richmond, CA). After washing, the microtiter plates were blocked with bovine serum albumin (BSA, 10 $\mathrm{mg} / \mathrm{ml}$ in PBS) with $1 \%$ normal goat serum and probed with dilutions of test samples and standards (recombinant baculovirus expressed cystatin M/E). As second antibody we used guinea pig anticystatin $\mathrm{M} / \mathrm{E}$ antiserum (1:6400 dilution in PBS, 0.05\% Tween-20, 0.1\% BSA) with $1 \%$ normal rabbit serum. Subsequently, the microtiter plates were incubated with biotinylated goat anti-guinea pig IgG (Vector Laboratories, Burlingame, CA) with $1 \%$ normal rabbit serum, followed by an incubation with the ABC complex. Finally ophenylenediamine dihydrochloride (Pierce, Rockford, IL) was added as chromogenic substrate for $15 \mathrm{~min}$ at room temperature. This enzyme reaction was stopped by the addition of $4 \mathrm{M} \mathrm{H}_{2} \mathrm{SO}_{4}$. Data were read with a BioRad ELISA reader at $492 \mathrm{~nm}$ and at $655 \mathrm{~nm}$.

\section{Antimicrobial assays}

Purified recombinant cystatin M/E (baculovirus-expressed) without the polyhistidine tag was tested for antimicrobial activity against the bacterium Staphylococcus aurews $42 \mathrm{D}$ and the yeast Candida albicans UC 820 in an antimicrobial assay as described previously ". Recombinant SLPI (a kind gift of Dr. R.C. Thompson, Synergen, Boulder, CO) and cystatin C (a gift from the Department of Oral Biochemistry, VU Amsterdam, The Netherlands) were used in comparison experiments with cystatin M/E.

\section{Preparation of protein extracts}

Normal skin and epidermal scales from a psoriatic patient were homogenized in buffer containing $50 \mathrm{mM}$ Tris- $\mathrm{HCl}, \mathrm{pH} 7.8$, and $100 \mathrm{mM}$ sodium chloride. The protein extracts were centrifuged for $30 \mathrm{~min}$ at $25,000 \mathrm{xg}$ and the supernatant was subsequently dialyzed against PBS and stored at $-20^{\circ} \mathrm{C}$ until further use.

\section{Cross-linking of cystatin $\mathrm{M} / \mathrm{E}$ to stratum corneum proteins by endogenous TGase}

For cross-linking experiments $200 \mu \mathrm{g}$ proteins from a psoriatic scale extract were used with $2 \mu \mathrm{g}$ of baculovirus-expressed purified recombinant cystatin $\mathrm{M} / \mathrm{E}$. Buffer and reaction conditions were as previously described ${ }^{21}$. Reaction mixtures containing $20 \mathrm{mM}$ ethylenediamine tetraacetic acid (EDTA), $\mathrm{pH} 7.8$, were used as controls. The reaction mixtures were subjected to sodium dodecyl sulfate polyacrylamide gel electrophoresis (SDS-PAGE) and electroblotted onto polyvinylidenedifluoride (PVDF) membrane (Millipore, Bedford, 
MA). The membrane was incubated with affinity-purified polyclonal rabbit anticystatin $\mathrm{M} / \mathrm{E}$ antibodies at a 1:15,000 dilution. This step was followed by incubation with swine antirabbit horseradish peroxidase (SWARPO; Dako, Glostrup, Denmark) at a 1:1,000 dilution. Cross-linked cystatin M/E was detected with the Phototope-HRP Western Blot Detection Kit (New England Biolabs, Beverly, MA). This assay uses LumiGLO chemiluminescent reagent and peroxide. The light emitted by destabilized LumiGLO reagent is subsequently captured on X-Omat S1 films (Kodak), and processed using the Imagemaster data image system (Pharmacia).

\section{Cross-linking of biotinylated peptides to cystatin $\mathrm{M} / \mathrm{E}$ by exogenous TGase}

Four hexapeptides, based on the TGase substrate motif of human SKALP/elafin ${ }^{22}$, with an NH2-terminal biotin followed by a C6-spacer were synthesized: GQDPVK, GQDPVR, GNDPVK, and GNDPVR (Eurosequence, Groningen, The Netherlands). For cross-linking experiments $6 \mu \mathrm{g}$ of baculovirus-expressed purified recombinant cystatin $\mathrm{M} / \mathrm{E}$ was used with $0.5 \mu \mathrm{g}$ of biotinylated peptide and $3 \mu \mathrm{l}(0.0313 \mathrm{units} / \mathrm{ml})$ of guinea pig liver TGase (Sigma). The reaction mixtures were blotted directly onto PVDF membranes by a slot blot manifold. The membrane was incubated with an HRP-linked antibiotin antibody, and biotinylated proteins were detected with the Phototope-HRP Western Blot Detection Kit as described above.

\section{Purification of cystatin M/E from human skin}

Affinity-purified polyclonal rabbit anticystatin $\mathrm{M} / \mathrm{E}$ antibody was coupled to $\mathrm{CNBr}$-activated Sepharose $4 \mathrm{~B}$, and this antibody-agarose conjugate was subsequently used to purify the native cystatin $\mathrm{M} / \mathrm{E}$ protein from psoriatic scale extracts according to the protocol provided by the manufacturer. The collected proteins were subjected to SDS-PAGE and electroblotted onto PDVF membrane. The membrane was incubated with affinity-purified polyclonal rabbit anticystatin $M / E$ and native cystatin $M / E$ was detected with the Phototope-HRP Western Blot Detection Kit as described above.

\section{SDS-PAGE and Western blotting}

Samples (TGase assay reaction mixtures, purified native protein) were diluted with SDS sample buffer (containing dithiothreitol) and boiled for $2 \mathrm{~min}$. These protein samples were separated by SDS-PAGE on a $15 \%$ Tris-glycine Ready gel (BioRad) using Tris-glycine as electrophoresis buffer ${ }^{40}$. 


\section{Cystatin $\mathrm{M} / \mathrm{E}$ is expressed by epidermal keratinocytes in vitro and in vivo}

Keratinocyte gene expression was comprehensively examined by means of SAGE on cultured human keratinocytes. In our SAGE libraries a total of 25,694 tags were analyzed, corresponding to 10,224 genes, many of which were not known to be expressed in keratinocytes (for details of this analysis see Jansen et al. "). A large number of keratinocytespecific transcripts, coding for proteins involved in epidermal differentiation and skin barrier function, were identified ( $6 \%$ of all transcripts). Surprisingly, a significant part of the identified transcripts accounted for genes involved in host protection such as antimicrobial proteins and proteinase inhibitors (2\% of all transcripts). High expression levels were found for members of the cystatin family, SLPI and SKALP/elafin. Cystatin M/E, a recently described family 2 cystatin not previously known to be expressed by adult human keratinocytes, was found at intermediate levels in the SAGE library of cultured keratinocytes ( $0.04 \%$ of all transcripts). On the basis of its expression in our SAGE libraries we decided to investigate whether cystatin $\mathrm{M} / \mathrm{E}$ was also expressed in human skin in vivo. Affinitypurified polyclonal antibodies against recombinant cystatin $M / E$ were used for a comprehensive expression study on a large panel of human tissues (see Materials and Methods for a complete list of tissues examined). We found that cystatin $M / E$ showed a tissue-specific expression pattern that was limited to epithelial cells in skin and nasal cavity. FIgure 1 shows the immunolocalization of cystatin $M / E$ in these tissues. In normal, nonpalmoplantar skin, cystatin $\mathrm{M} / \mathrm{E}$ is highly expressed in the stratum granulosum and weakly in the spinous layers (FIGUre 1A). Positive staining for cystatin $\mathrm{M} / \mathrm{E}$ in several (five to seven) layers of suprabasal spinous cells was seen in psoriatic lesional skin (FIGURE 1B), whereas the granular cells are not stained as strongly as in normal skin. Differentiated keratinocytes of the infundibular epithelium of the hair follicle were also found to be positive for cystatin $\mathrm{M} / \mathrm{E}$ (FIGURE 1C). In plantar skin, positive staining for cystatin $\mathrm{M} / \mathrm{E}$ was seen in several layers of the suprabasal spinous cells (FIGURE 1D), which resembles the pattern in psoriatic skin. In the epidermis of the foot sole, a duct of a sweat gland is positively stained for cystatin M/E (FIGURE 1D, arrowhead). The secretory coils of eccrine sweat glands that are found in the deep dermal part of the foot sole (FIGURE IE) are also positively stained for cystatin $\mathrm{M} / \mathrm{E}$ (arrow). In contrast with the epidermal part of the sweat gland duct, the dermal part of the duct is almost negative (arrowheads). A slight cystatin M/E staining is found in mucous glands in the nasal cavity (FIGURE IF, arrows). No expression of cystatin $\mathrm{M} / \mathrm{E}$ was seen in any of the other human tissues examined by IHC (data not shown). To examine the expression at the mRNA level we performed RT-PCR analysis on almost the same panel of human rissues. As shown in FIGURE 2, this analysis confirmed that cystatin $\mathrm{M} / \mathrm{E}$ gene expression is restricted to human skin, which is demonstrated by the 496 bps PCR product, generated using cystatin M/E specific oligonucleotides. Sequencing of this 496 bps product was performed to verify that it was indeed cystatin $M / E$. Because the availability of the mRNA of the various tissue samples was limited, we could not perform Northern blot analysis on all of them, which would give a more quantitative measure for mRNA levels. Northern blor analysis was performed on skin biopsies ( $n=7)$, foot sole $(n=1)$, oral epithelia $(n=1)$, and peripheral blood leukocytes $(n=5)$, which revealed a strongly hybridizing band of $0.6 \mathrm{~kb}$ in the lanes loaded with RNA from skin (FIGURE 3, lanes 1-7). A weak signal was seen in foot sole but this lane was clearly underloaded compared to normal skin (lane 8), whereas oral epithelia (lanes 9-11) and all blood samples were negative for cystatin $\mathrm{M} / \mathrm{E}$ (lanes 12-16). 


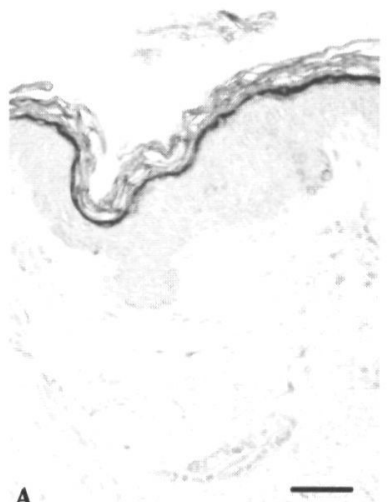

A

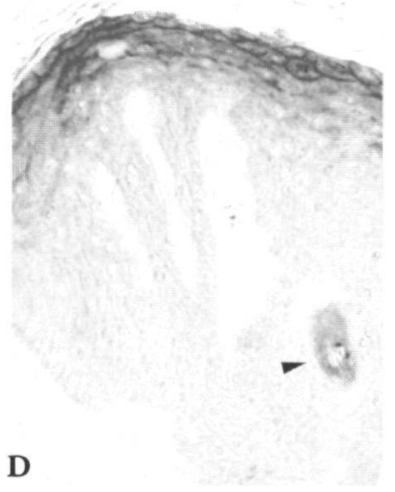

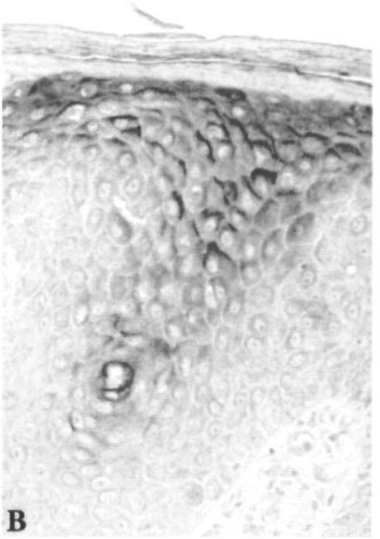
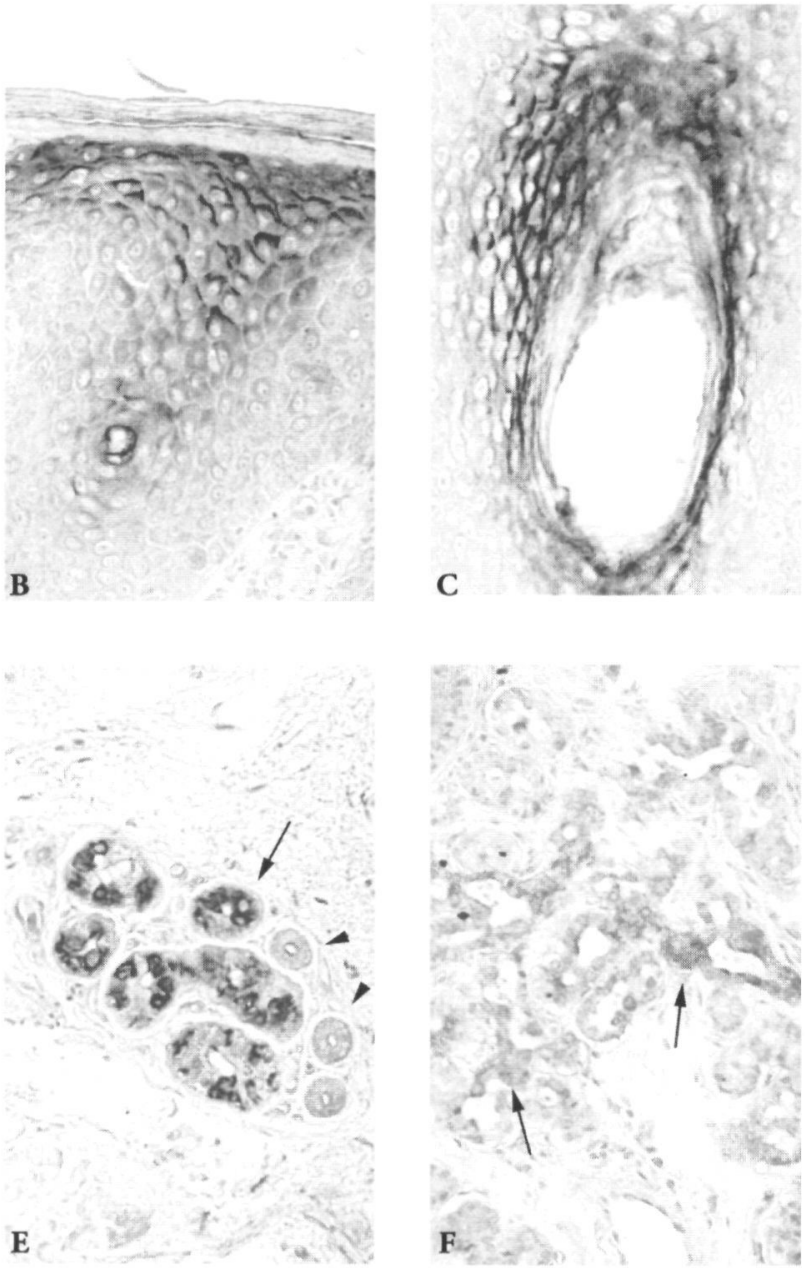

FIGURE 1 Immunohistology of human skin. Formalin fixed sections of biopsies were incubated with purified rabbit anticystatin M/E polyclonal antibodies. A) Normal skin. The staining is limited to the upper layers of the suprabasal compartment, which contains mainly granular cells. B) Psoriatic lesional skin. Staining of cystatin $\mathrm{M} / \mathrm{E}$ is less intense in the stratum granulosum, but several layers of the suprabasal spinous cells are positive. No staining was seen in the basal cells, either in normal skin or psoriatic lesional skin. C) Hair follicle. Strong staining of differentiated keratinocytes of the infundibular epithelium. D) Epidermis of the sole of the foot. A strong staining was observed in several layers of the differentiated compartment. E) Sweat glands in the sole of the foot. Note that the secretory coil of the gland is strongly positive, whereas the ductal part is almost negative. F) Mucous glands of the nasal cavity show a weak positive staining. Scale bar: $40 \mu \mathrm{m}$. See last pages for colour image of this figure. 


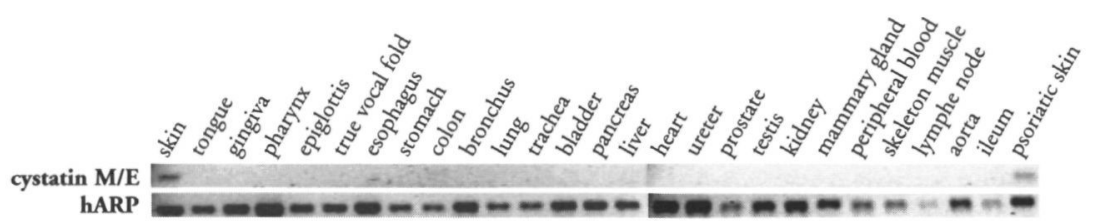

FIGURE 2 RT-PCR analysis of cystatin M/E expression in human tissues. RT-PCR products derived from mRNA of a large panel of human tissues were elecrophoretically separated on agarose gel. At the top, amplifications performed with cystatin M/E specific primers. At the bottom, amplifications performed with hARP0 specific primers, which served as a reference housekeeping gene.

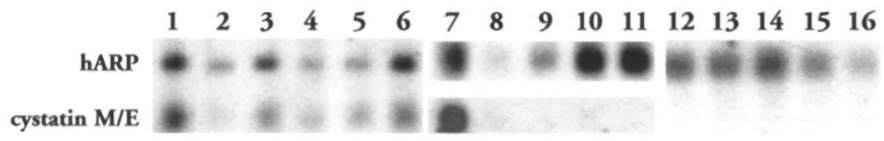

FIGURE 3 Northern blot analysis of cystatin M/E expression in human tissues. Ten micrograms of total RNA were loaded and probed with $\left[\alpha-{ }^{32} \mathrm{P}\right]$-labeled cystatin M/E cDNA. hARP0 was used for control hybridization to check for equal mRNA loading. Lanes 1 , 4, and 7 represent normal skin, and lanes 2,3,5, and 6 represent psoriatic skin. Foot sole (lane 8) and oral epithelia (lanes 9-11), which represent, respectively, tongue, gingiva, and pharynx, are negative for cystatin $\mathrm{M} / \mathrm{E}$ expression. Also, several samples of RNA derived from peripheral blood leukocytes were negative for cystatin M/E (lanes 12-16).

\section{Isolation and characterization of recombinant cystatin $\mathrm{M} / \mathrm{E}$}

To further investigate the functional properties of cystatin $\mathrm{M} / \mathrm{E}$ we produced recombinant protein, both in a bacterial expression system as a GST fusion protein and as a fully processed protein (lacking the signal peptide) in an eukaryotic system using the baculovirus in insect cells. The purified GST fusion protein was detected on SDS-PAGE as a single $40 \mathrm{kDa}$ band as previously described ${ }^{12}$ (FIGURE 4, lane 1). Cystatin M/E cleaved from the GST-cystatin M/E fusion protein by thrombin migrates with an apparent size of $14 \mathrm{kDa}$ (FIGURE 4, lane 2). The purified baculovirus-expressed protein was found on SDSPAGE as a doublet of, respectively, 14 and $16 \mathrm{kDa}$, where the upper band was suspected to be a glycosylated species of cystatin M/E ${ }^{13}$ (FIGURE 4, lane 3). To test whether both recombinant proteins are functional proteinase inhibitors, cystatin M/E inhibitory activity was measured by titration of papain activity in the absence and presence of increasing concentrations of inhibitor, as described by Sotiropoulou et al. ${ }^{12}$. It was found that baculovirus expressed (not shown) and bacterially expressed cystatin M/E both displayed inhibitory activity against the cysteine proteinase papain. The inhibitory activity of cystatin M/E cleaved from the GST-cystatin M/E fusion protein is shown in FIGURE 5. Papain hydrolysis of the fluorogenic substrate Z-Phe-Arg-AMC was almost completely inhibited in the presence of $5 \mathrm{nM}$ cystatin M/E (FIGURE 5A), whereas recombinant GST did not have any effect on papain activity (not shown). Using the same assay we found a moderate inhibitory activity against cathepsin $\mathrm{B}$ as cystatin $\mathrm{M} / \mathrm{E}$ was used up to micromolar concentrations (FIGURE 5B). As deficiency for cathepsin C was recently described to be the cause of Papillon-Lefevre syndrome ${ }^{41}$, cathepsin C is likely to be an important proteinase for epidermal homeostasis. For this reason we were interested to know if cystatin M/E could inhibit cathepsin $\mathrm{C}$. Based on the $\mathrm{pH}$-dependent activation of cathepsin $\mathrm{C}$ by chlo- 
FIGURE 4 Purification of recombinant cystatin M/E. SDS-PAGE in a $20 \%$ gel on the PhastSystem and silver staining. Bacterially expressed and affinity purified recombinant GST-cystatin M/E fusion protein, and cystatin $\mathrm{M} / \mathrm{E}$ cleaved from the fusion protein by thrombin are shown in lanes 1 and 2 , respectively. Baculovirus expressed and affinity purified recombinant cystatin $M / E$ is shown in lane 3. Lane M, molecular weight markers, with sizes of relevant bands indicated at the left.

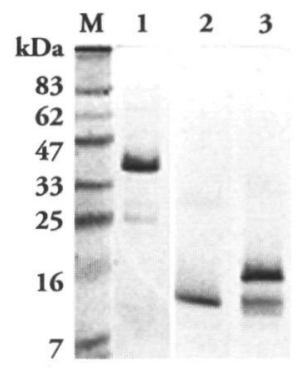

Papain

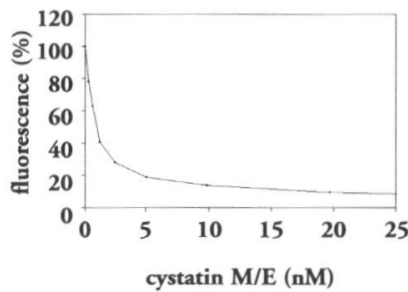

Cathepsin B

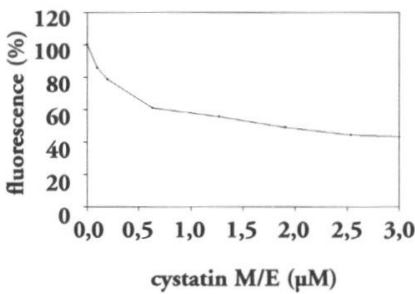

Cathepsin C

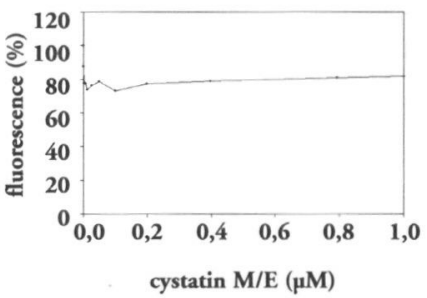

FIGURE 5 Cystatin $\mathrm{M} / \mathrm{E}$ inhibitory activity. Inhibition of cysteine proteinases by cystatin $\mathrm{M} / \mathrm{E}$ was measured by titration of A) papain, B) cathepsin B, and C) cathepsin C activity in the absence and presence of increasing concentrations of inhibitor. The fluorogenic substrate Z-Phe-Arg-AMC was used in the papain and cathepsin B enzyme assay, whereas $\mathrm{H}$-Gly-Phe-AMC was used in the cathepsin $\mathrm{C}$ enzyme assay. Representative curves of at least three experiments are shown.

ride ions ${ }^{42}$, and using a cathepsin $\mathrm{C}$ specific synthetic substrate (H-Gly-Phe-AMC), we could demonstrate the presence of cathepsin $\mathrm{C}$ in normal human skin extracts. No inhibition of substrate hydrolysis could be detected, however, in the presence of increasing amounts of recombinant cystatin M/E (FIGURE $5 \mathrm{C}$ ). In addition to its proteinase inhibitory activity, we tested cystatin $\mathrm{M} / \mathrm{E}$ for possible direct antimicrobial activity as was described for other known proteinase inhibitors. Recombinant baculovirus expressed cystatin $\mathrm{M} / \mathrm{E}$, which was digested with TEV proteinase to remove the polyhistidine tag, showed no detectable bacterial killing against the tested gram-positive bacterium $S$. aureus, whereas SLPI, a well-known broad-range antimicrobial protein, effectively inhibits growth of this bacterium (data not shown). Additionally, the growth of $C$. albicans was completely inhibited by SLPI, whereas cystatin M/E and cystatin C appeared to be ineffective.

\section{Cystatin M/E is a target for cross-linking by TGase}

The expression pattern of cystatin $\mathrm{M} / \mathrm{E}$ raised the possibility that this protein could be involved in barrier function in human skin. Furthermore, its presence in terminally differentiated keratinocytes as demonstrated with IHC suggested that it could be a structural part of the stratum corneum, e.g., by TGase-mediated cross-linking. In earlier work we reported that the serine proteinase inhibitor SKALP/elafin possesses TGase substrate motifs that can act as an anchoring sequence to cornified envelope proteins ${ }^{21}$. To investigate if cystatin $\mathrm{M} / \mathrm{E}$ is a possible substrate for TGase, we used biotinylated hexapeptide 


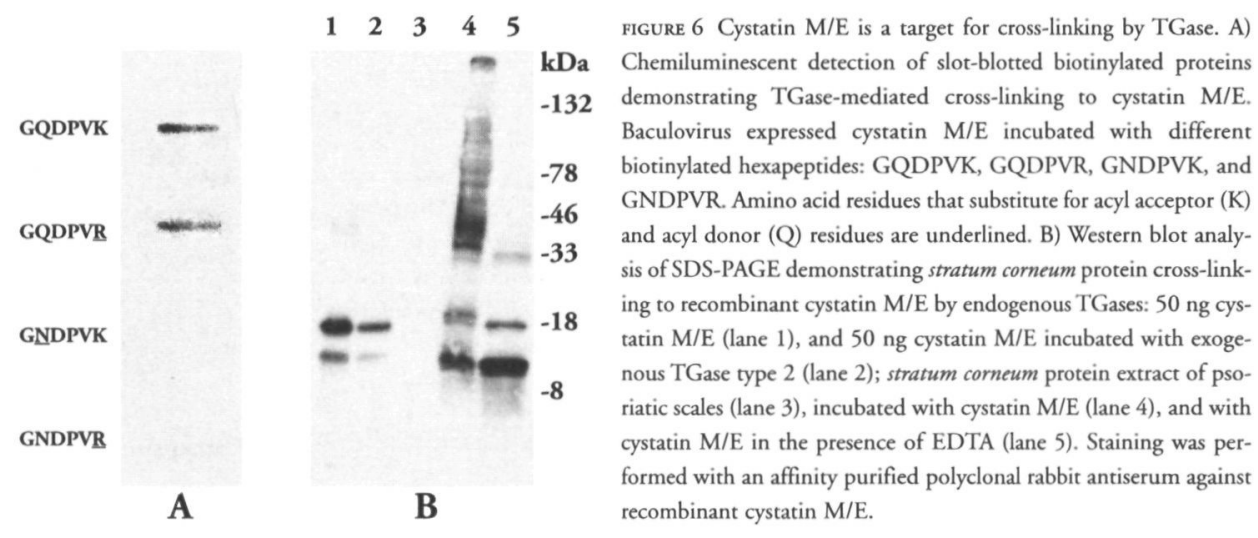

probes based on the TGase substrate motif of human SKALP/elafin in cross-linking reactions that were catalyzed by exogenous tissue type 2 TGase. The TGase cross-linking reaction is based on a $\mathrm{Ca}^{2+}$-dependent exchange of primary amines for ammonia at the $\gamma$-carboxamide group of glutamine residues. Peptide-bound lysine residues or polyamines serve as the primary amines to form either $\varepsilon$ - $(\gamma$-glutamyl)lysine or $(\gamma$-glutamyl)polyamine bonds between proteins ${ }^{43}$, which are highly resistant to chemical and enzymatic degradation ${ }^{44}$. Recombinant cystatin M/E was shown to be an efficient substrate for tissue type 2 TGase (FIGURE 6A). Cross-linking was demonstrated using the GQDPVK hexapeptide (an acyl donor and acceptor probe) and the GQDPVR hexapeptide (an acyl donor probe). No cross-linking was observed, however, when the GNDPVK hexapeptide (an acyl acceptor probe) or GNDPVR hexapeptide (a probe in which both Q and K have been replaced, and which is no longer a TGase substrate) were used, indicating that cystatin $\mathrm{M} / \mathrm{E}$ acts as an acyl acceptor. Specificity was checked by the addition of excess EDTA, as a control for the $\mathrm{Ca}^{2+}$-dependent reaction (not shown). In addition to cross-linking of cystatin $\mathrm{M} / \mathrm{E}$ to the biotinylated hexapeptides, we also used an aqueous extract of stratum corneum derived from a psoriatic patient as a source of natural substrate proteins and endogenous TGases (FIGURE 6B). Analysis by SDS-PAGE showed incorporation of cystatin M/E in proteins predominantly between 30 and $100 \mathrm{kDa}$ (lane 4), whereas the addition of excess EDTA prevents cross-linking of cystatin M/E (lane 5). Lane 3 is a blank of stratum corneum extract without cystatin $\mathrm{M} / \mathrm{E}$ added. To check self cross-linking, recombinant cystatin $\mathrm{M} / \mathrm{E}$ was incubated with exogenous TGase type 2 without the scale extract (lane 2), but no additional bands were detected.

\section{Induction of cystatin $\mathrm{M} / \mathrm{E}$ in cultured human keratinocytes}

Two other epidermal host defense proteins that were recently described (SKALP/elafin and SLPI) are known to be induced in differentiated cultures of epidermal keratinocytes ${ }^{19.45}$. We investigated the induction of cystatin M/E by FBS, as we have previously shown that SKALP/elafin and SLPI are both highly upregulated by FBS or normal human serum ${ }^{46}$. We used culture systems that we have previously described ${ }^{35}$ that allow the induction of regenerative differentiation of keratinocytes by the addition of serum. Northern blot analysis (FIGURE 7) showed that cystatin M/E mRNA is strongly upregulated in these cultures. This induction was also found at the protein level as detected by ELISA on the supernatant 
FIGURE 7 Induction of cystatin M/E mRNA expression in cultured keratinocytes by FBS. Ten micrograms of total RNA was loaded and probed with $\left[\alpha-{ }^{32} \mathrm{P}\right]$-labeled cystatin M/E cDNA. To check for equal RNA loading, the $18 \mathrm{~S}$ and $28 \mathrm{~S}$ ribosomal RNA signals are shown in adjacent lanes (lanes 1 and 3). Lane 2, undifferentiated keratinocytes cultured in basal medium (KGM); lane 4, differentiated keratinocytes cultured in KGM with FBS.

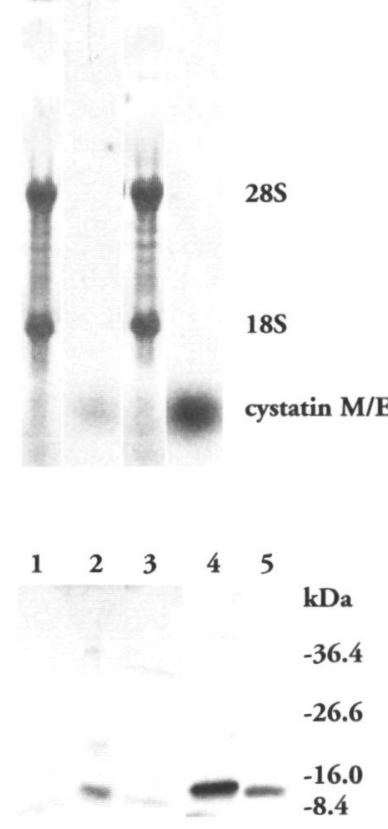

FIGURE 8 Detection of cystatin M/E by Western blotting. Concentrated culture supernatants of undifferentiated keratinocytes and differentiated keratinocytes are shown in lanes 1 and 2, respectively, whereas concentrated human sweat is shown in lane 3. Lane 4, recombinant cystatin $\mathrm{M} / \mathrm{E}(14 \mathrm{kDa})$ cleaved from the fusion protein; lane 5, affinity purified native cystatin $\mathrm{M} / \mathrm{E}$ from psoriatic scale extract.

of cultured keratinocytes. In undifferentiated keratinocytes we found no detectable amounts of cystatin $\mathrm{M} / \mathrm{E}$ in the supernatant, whereas the supernatant of differentiated keratinocytes contained significant levels of cystatin M/E (85 ng/ml).

\section{Cystatin $\mathrm{M} / \mathrm{E}$ is a secreted protein in vitro and in vivo}

Based on the hydrophobic amino acid $\mathrm{N}$-terminal sequence of cystatin $\mathrm{M} / \mathrm{E}^{12}$, coding for a putative signal peptide, it was supposed that cystatin $\mathrm{M} / \mathrm{E}$ could be secreted. As mentioned in the previous paragraph, cystatin $\mathrm{M} / \mathrm{E}$ was found to be secreted in vitro in the supernatant of cultured keratinocytes. We also demonstrated by ELISA that cystatin $\mathrm{M} / \mathrm{E}$ is secreted in vivo in human sweat and in low amounts in nasal mucus (respectively 88 and $7 \mathrm{ng} / \mathrm{ml}$ ). These results were confirmed by Western blot analysis, which showed a single 14 $\mathrm{kDa}$ band of cystatin $\mathrm{M} / \mathrm{E}$ in concentrated $(5 \mathrm{x})$ culture supernatant of differentiated keratinocytes and concentrated human sweat (FIGURE 8, lanes 2-3), whereas in concentrated culture supernatant of undifferentiated keratinocytes no cystatin $\mathrm{M} / \mathrm{E}$ could be detected (FIGURE 8, lane 1). For comparison, recombinant cystatin $\mathrm{M} / \mathrm{E}$ cleaved from the fusion protein was run on the gel (FIGURE 8 , lane 4). We could also detect native cystatin $\mathrm{M} / \mathrm{E}$ in psoriatic scale extracts, which was purified by affinity chromatography (FIGURE 8 , lane 5 ). 
SAGE is an efficient and comprehensive approach to examining cellular gene expression profiles, as we have recently done on cultured human keratinocytes "13. Using this technique we have identified a number of new genes, and several genes not previously known to be expressed in epidermis. One of these, cystatin $\mathrm{M} / \mathrm{E}$, is characterized in this paper. We show by $\mathrm{IHC}$ that cystatin $\mathrm{M} / \mathrm{E}$ protein expression in vivo is largely restricted to human skin. This observation is an apparent discrepancy with previous studies, which have reported expression of cystatin $\mathrm{M} / \mathrm{E}$ at the mRNA level in several other human tissues ${ }^{12.13}$. These two papers, however, are also contradictory with respect to the observed expression in tissues such as brain, liver, and peripheral blood leukocytes. A possible explanation for the inconsistencies between these two papers is a difference between expression at the mRNA and protein level. We have found, however, that Northern blotting and RT-PCR analysis on mRNA extracted from fresh autopsy and biopsy material confirms the specific expression of cystatin $M / E$ in human skin. It is therefore likely that additional, hitherto unidentified transcripts with high similarity to the cystatin $\mathrm{M} / \mathrm{E}$ probe are present in specialized rissues ${ }^{13}$. This assumption is plausible considering that transcripts larger in size than $0.6 \mathrm{~kb}$ were found by Northern blot analysis ${ }^{12}$, and it was not clear whether these transcripts originate from cystatin $M / E$ or from a closely related gene.

High cystatin M/E expression at the protein level was found only in the stratum granulosum of normal skin, in hair follicle, and in eccrine sweat glands. In psoriatic skin an increased number of cystatin $\mathrm{M} / \mathrm{E}$ positive cells was found, possibly resulting from inflammatory cytokines that are known to induce abnormal differentiation ${ }^{45}$. Cysteine proteinases and their endogenous inhibitors are known to be present in human eccrine sweat ${ }^{47}$, and cystatin $\mathrm{M} / \mathrm{E}$ could be one of the natural inhibitors. The constitutive expression could be explained by high levels of cytokines, which are present in normal human skin eccrine sweat gland duct and secretory coil epithelium ${ }^{48}$. Further regulatory features of cystatin $M / E$ and the possible involvement of inflammatory cytokines remain to be investigated, however.

Both in vivo and in vitro we found that cystatin $\mathrm{M} / \mathrm{E}$ is a secreted protein. Using $\mathrm{IHC}$, however, we could demonstrate high levels within the cells. In addition, the finding that cystatin $\mathrm{M} / \mathrm{E}$ could be cross-linked to stratum corneum proteins, a process that occurs within the cell during terminal differentiation, opens the possibility that cystatin $M / E$ also acts within the cell. Although these findings appear paradoxical, similar data have been reported for SKALP/elafin and SLPI, two other secreted epidermal proteinase inhibitors. SKALP/elafin, which is secreted into the extracellular space, was found to be cross-linked to loricrin and other cornified envelope components ${ }^{30}$, and ultrastructurally it was found in granules other than secretory lamellar granules ${ }^{27}$. SLPI, a secreted proteinase inhibitor, is known to interfere with lipopolysaccharide signaling ${ }^{49}$, but rather surprisingly it was recently shown that SLPI acts intracellularly rather than extracellularly ${ }^{50}$. By analogy, these findings leave open the possibility that cystatin $\mathrm{M} / \mathrm{E}$ has multiple functions, both intracellularly and extracellularly.

The presence of cystatin $\mathrm{M} / \mathrm{E}$ in the stratum granulosum opens the possibility that this molecule has a role in the physical barrier of human skin formed by the stratum corneum. The protective callus layer resulting from terminal differentiation of the squamous epithelium is thought to be cross-linked by different TGase activities present in mammalian epidermis. Four TGases (TGase 1, 2, 3, and X) are known to be expressed in the epidermis ${ }^{30.51 .54}$, but thus far only limited data are available with respect to their substrate specificities and relative 
contributions in $C E$ assembly. In vitro, we have shown that cystatin $M / E$ is an efficient substrate for tissue type 2 TGase in cross-linking reactions with biotinylated hexapeptides. Cross-linking of the biotinylated GQDPVK and GQDPVR hexapeptides to recombinant cystatin $\mathrm{M} / \mathrm{E}$ was observed, but substitution of the acyl donor residue glutamine (Q) for asparagine (N) totally abolished cross-linking of the biotinylated GNDPVK and GNDPVR hexapeptides. From these results we can surmise that cystatin $\mathrm{M} / \mathrm{E}$ acts as an acyl acceptor but not as acyl donor. We could not detect oligomerization of recombinant cystatin $\mathrm{M} / \mathrm{E}$ in a reaction with exogenous TGase 2, suggesting that the glutamine (Q) residues of cystatin $\mathrm{M} / \mathrm{E}$ do not take part in the cross-linking reaction catalyzed by TGase 2.

Desquamation is the final event in terminal differentiation of the epidermis, which occurs by the action of proteolytic enzymes. During desquamation there is proteinase-mediated breakdown of the desmosomal cohesive complexes that link the corneocytes 5557 . There is some evidence indicating that stratum corneum chymotryptic enzyme (SCCE), a serine proteinase, is responsible for the degradation of desmosomes leading to desquamation ${ }^{58,59}$. Recently the inhibition of SCCE by SLPI was described, which may be of importance in the regulation of epidermal homeostasis ${ }^{60}$. Besides other stratum corneum serine proteinases that have been implicated in desquamation ${ }^{61}{ }^{63}$, recently an aspartic proteinase, cathepsin D, was found that appears to be associated with the final stage of desquamation ${ }^{64}$. Lysosomal cysteine proteinases such as cathepsin $B$ and $L$ are known to be expressed in the basal and spinous layers of normal skin mainly as inactive precursors. These proteins were processed to activated mature enzymes in psoriatic epidermis ${ }^{65}$, where they are thought to be involved in the keratinization process. Cystatin $\mathrm{M} / \mathrm{E}$ is a moderately active inhibitor of cathepsin $\mathrm{B}$, which indicates that this cysteine proteinase inhibitor could have a possible function in the regulation of keratinization and desquamation. It is more likely, however, that the target protein for cystatin $\mathrm{M} / \mathrm{E}$ is found in the extracellular space as it could be secreted. Interestingly, a new cysteine proteinase of late epidermal differentiation, stratum comeum thiol proteinase (SCTP), was recently described by Watkinson ${ }^{6}$, and could be a possible target enzyme for cystatin $\mathrm{M} / \mathrm{E}$. SCTP appears to be a specific product of differentiated keratinocytes, and furthermore it is apparently not stored within these cells but is actively secreted. A role for SCTP in degradation of extracellular stratum corneum substrates, which have been linked with the desquamatory process, and its possible regulation by cystatin $\mathrm{M} / \mathrm{E}$ remain to be explored.

Finally, in addition to a role in regulation of endogenous proteinases, it is conceivable that cystatin $\mathrm{M} / \mathrm{E}$ is involved in regulation of exogenous proteinases derived from the commensal skin flora or potential skin pathogens. Although we could not demonstrate a direct microbicidal effect in vitro, it is very possible that microbial proteinases involved in skin colonization and invasion are targets for cystatin $\mathrm{M} / \mathrm{E}$. Clearly, identification of potential microbial target proteins or generation of cystatin $\mathrm{M} / \mathrm{E}$ knockout mice could shed further light on the biologic function of this molecule and its presumed role in epidermal homeostasis.

\section{Acknowledgements}

We thank Anke van Vught (Department of Ophthalmology, University Hospital Nijmegen, The Netherlands) for technical assistance on the recombinant baculovirus procedures, and Ilse Breuker (Department of Medical Microbiology, University Hospital Nijmegen, The Netherlands) for technical assistance and providing materials for the antimicrobial assays. This work was financially supported by the Netherlands Organization for Scientific Research (NWO), and in part by the Dutch Cancer Society (KWF). 
1 Turk V, Bode W The cystatins: proresn inhibitors of cysteine proteinases.

FEBS Lett 1991;285(2):213-9.

2 Abrahamson M Cystatins

Methods Enzymol 1994,244:685-700.

3 Bjorck L. Proteınase inhibitıon, 1mmunoglobulinbinding proteıns and a novel antımicrobıal prıncıple Mol Microbıol 1990,4(9):1439-42

4 Bobek LA, Levine MJ Cystatins--ınhubıtors of cysteine proteinases.

Crit Rev Oral Biol Med 1992;3(4):307-32.

5. Henskens YM, Veerman EC, Nieuw Amerongen AV. Cystatins in health and disease.

Biol Chem Hoppe Seyler 1996;377(2)·71-86.

6. Calkuns CC, Sloane BF. Mammalan cysteıne prorease inhibitors: biochemical properties and possible roles in tumor progression. Biol Chem Hoppe Seyler 1995;376(2):71-80

7 Bjorck L, Akesson P. Bohus M, Trojnar J, Abrahamson M, Olafsson I, et al Bacterial growth blocked by a synthetic pepude based on the structure of a human proteinase inhibiror. Nature 1989;337(6205)·385-6

8 Blankenvoorde MF, van't Hof W, Walgreen-Weterıngs E, van Steenbergen T], Brand HS, Veerman EC, et al. Cystatın and cystatın-derıved peptıdes have antibacterıal activity aganst the pathogen Porphyromonas gingivalus Biol Chem 1998,379(11) 1371-5

9 Korant BD, Towatarı T, Ivanoff L, Petteway S, Jr. Bran J, Lenareic B, et al. Viral therapy: prospects for protease inhibitors

J Cell Biochem 1986;32(2) 91-5

10 Bjorck L, Grubb A, Kjellen L Cystatın C, a human proteinase inhibitor, blocks replication of herpes simplex virus. J Virol 1990;64(2):941-3

11 Rawlings ND. Barrett AJ. Evolution of proteins of the cystatın superfamily

J Mol Evol 1990;30(1) 60-71

12. Sotıropoulou G, Anisowicz A, Sager $R$ Idenufication, cloning, and characterization of cystatın $\mathrm{M}$, a novel cysteine proteınase inhibitor, down-regulared in breast cancer.

J Biol Chem 1997,272(2) 903-10.

13 Nı J, Abrahanson M, Zhang M, Fernandez MA, Grubb A, Su J, et al. Cystatın $E$ is a novel human cysteine proteinase inhibitor with siructural resemblance to family 2 cystatıns. J Biol Chem 1997:272(16):10853-8
14 Boman HG Gene-encoded pepude antubiotics and the concept of innate immunity. an update review Scand J Immunol 1998;48(1):15-25

15 Lehrer R, Ganz T Antimicrobial peptudes in mammalian and insect host defence. Curr Opın Immunol 1999;11(1)·23-7.

16. Medzhitov R, Janeway CA, Jr. Innate immune recognition and control of adaptive immune responses. Semin Immunol 1998;10(5) 351-3

17. Hiemstra PS, Maassen RJ, Stolk J, Heinzel-Wieland R, Steffens GJ, Dijkman JH. Antibacterial activity of antuleukoprotease. Infect Immun 1996;64(11) -4520-4

18. Wiedow O, Harder J, Bartels J, Strett V, Chrsstophers E. Antıleukoprotease in human skin an antibiotic peptide constitutively produced by keratinocytes Bıochem Biophys Res Commun 1998;248(3):904-9

19. Wingens $M$, van Bergen BH, Hiemstra PS, Meis JF, van Vlijmen-Willems IM, Zeeuwen PL, et al Induction of SLPI (ALP/HUSI-I) in epidermal keratinocytes.

J Invest Dermatol 1998;1 I I(6):996-1002.

20. Simpson AJ, Marwell AJ, Govan JR, Haslett C, Sallenave JM. Elafin (elastase-specific unhibıtor) has anti-microbial activicy against gram-posituve and gram-negattve respiratory pathogens FEBS Lett 1999;452(3):309-13.

21 Zeeuwen PL, Hendriks W, de Jong WW, Schalkwıjk J. Identification and sequence analysıs of two new members of the SKALP/elafin and SPAI-2 gene family. Brochemical properties of the transglutaminase substrate motif and suggestions for a new nomenclarure

J Biol Chem 1997;272(33):20471-8

22 Schalkwık J, Wiedow O, Hırose S The trappin gene family: proteins defined by an N-terminal transglutaminase substrate domain and a C-terminal four-disulphide core. Biochem J 1999;340(Pr 3):569-77

23. Thompson RC, Ohlsson K. Isolation, properties, and complete amıno acid sequence of human secretory leukocyte protease inhibitor, a potent inhibiror of leukocyte elastase Proc Natl Acad Sc U S A 1986;83(18).6692-6.

24. Schalkwijk J, Chang A, Janssen P, De Jongh GJ, Mier PD. Skun-derived ancileucoproteases (SKALPs) characterization of two new elastase inhibitors from psoriatic epıdermıs Br J Dermatol 1990;122(5):631-41 
25. Wiedow O, Schroder JM, Gregory H, Young JA, Christophers E. Elafin. an elastase-specific inhibitor of human skin. Purification, characterization, and complete amino acad sequence.

J Bıol Chem 1990;265(25) 14791-5.

26. Molhuizen HO, Alkemade HA, Zeeuwen PL, de Jongh GJ, Wierınga B, Schalkwık J SKALP/elafin. an elastase inhibitor from cultured human keraunocytes Punfication, cDNA sequence, and evdence for tansglutamunase cross- lınkung-J Bıol Chem 1993;268(16) 12028-32

27. Pfundt $R$, van Russen $F$, van Vljmen-Willems $I M$, Alkemade HA, Zeeuwen PL, Jap PH, ex al Constitutive and inducible expression of SKALP/elafin provides anti- elastase defense in human epsthelı. J Clın Invest 1996;98(6):1389-99.

28 Robinson NA, Lapic S, Welter JF, Eckert RL. S100A11, S100A10, annexin I, desmosomal proteıns, small prolıne-rich proteins, plasmınogen actuvator inhibitor- 2 , and involucrin are components of the cornified envelope of cultured human epidermal keracinocytes J Biol Chem 1997;272(18):12035-46.

29 Nemes $Z$, Steınert PM Bricks and mortar of the epidermal barrier.

Exp Mol Med 1999;31(1)-5-19.

30 Steinert PM, Marekov LN. The proteıns elafin, filaggrin, keratın ıntermediate filaments, loricrın, and small prolıne-rich proteins 1 and 2 are ssodipepude cross-linked componenss of the human epidermal cornified cell envelope J Bıl Chem 1995;270(30):17702-11

31. Steinert PM, Marekov LN. Direct evidence that ınvolucrin is a major early isopeptıde cross- linked component of the keratınocyte cornıfied cell envelope. J Bıl Chem 1997;272(3)·2021-30

32. Takahashı M, Tezuka T, Katunuma N. Filaggrın linker segment peptide and cystatın alpha are parts of a complex of the cornified envelope of epidermis Arch Biochem Biophys 1996,329(1):123-6.

33. Jansen $B J H$, van Russen $F$, de Jongh $G$, Zeeuwen PLJM, Schalkwık J Serial analysis of gene expression in differentiated cultures of human epidermal keratınocytes J Invest Dermatol 2001;1 16(1) 12-22

34 Rheinwald JG, Green $H$ Formation of a keratunizing epithelium in culture by a cloned cell line derived from a ceratoma

Cell $1975,6(3) \cdot 317-30$
35 Van Ruissen F, de Jongh GJ, Zeeuwen PL, Van Erp PE, Madsen P, Schalkwijk J. Induction of normal and psoriatic phenorypes in submerged kerannocyce cultures. J Cell Physıl 1996,168(2)·442-52

36. Alkemade JA, Molhuizen HO, Ponec M, Kempenaar JA, Zeeuwen PL, de Jongh GJ, et al SKALP/elafin is an inducible proteinase inhibitor in human epidermal keratinocyies.

J Cell Sc1 1994;107(Pr 8) 2335-42

37. Latijnhouwers MA, Bergers $M$, Van Bergen $B H$, Spruıj KI, Andriessen MP, Schalkwıjk J Tenascin expression durıng wound healıng in human skın J Pachol 1996;178(1)·30-5

38. Wingens $M$, Pfundt $R$, van Vlymen-Wilems IM, van Hooıdonk CA, van Erp PE, Schalkwıjk J Sequence-specific inhibition of gene expression in intact human skun by epicutaneous application of chimeric antisense oligodeoxynucleotides Lab Invest 1999;79(11):1415-24

39. Toomes C, James J, Wood AJ, Wu CL, McCormick $D$, Lench $N$, et al Loss-of-function mutations in the carhepsin $\mathrm{C}$ gene result in periodontal disease and palmoplantar keracosıs Nat Genet 1999;23(4).421-4.

40 Laemnlı UK Cleavage of structural proteıns during the assembly of the head of bacteriophage T4. Nature 1970;227(259):680-5

41. Hart TC, Hart PS, Bowden DW, Michalec MD, Callıson SA, Walker SJ, et al Mutations of the cathepsin $\mathrm{C}$ gene are responstble for Papullon-Lefevre syndrome. J Med Gener 1999,36(12):88 1-7.

42 Cigic B, Pain RH Locacion of the binding site for chloride ion actuvation of cathepsin $\mathrm{C}$ Eur J Biochem 1999;264(3):944-5]

43 Folk JE, Finlayson JS. The epsilon-(gammaglutamyl) lysine crosslink and the catalytic role of transglutaminases.

Adv Proteın Chem 1977,31:1-133

44. Folk JE. Mechanism and basis for specificity of transglutarninase-catalyzed epsilon-(gammaglutamyl) lysine bond formation Adv Enzymol Relat Areas Mol Bıol 1983;54-1-56

45. Pfundt $R, W$ ingens $M$, Bergers $M$, Zweers $M$, Frenken M, Schalkwıjk J TNF-alpha and serum Induce SKALP/elafin gene expression in human keratınocytes by a 38 MAP kunase-dependent pathway. Arch Dermatol Res 2000,292(4).180-7 
Molhuizen HO. Molecular and cell biological characterization of the serine proteinase inhibitor SKALP Nımegen. Unıversıty of Nıjmegen, 1995.

47. Yokozeki H, Hıbıno T, Takemura T, Sato K. Cysteine proteinase inhibitor in eccrine sweat is derived from sweat gland.

Am J Physiol 1991;260(2 Pt 2):R314-20

48. Boehm KD, Yun JK, Garner C, Strohl KP, Elmets CA In situ detection of cytokne messenger RNAs in the eccrine sweat gland of normal human skın Lymphokıne Cyrokıne Res 1994;13(1)·9-13.

49. Jin FY, Nathan C, Radzıoch D, Ding A. Secretory leukocyte prorease inhibitor a macrophage product induced by and antagonistic to bacterial lipopolysacchande. Cell 1997,88(3):417-26.

50. Zhu J, Nathan C. Ding A Suppression of macrophage responses to bacterial lipopolysaccharide by a non-secretory form of secretory leukocye protease inhibitor Blochim Bıophys Acta 1999;1451(2-3):219-23.

51. Greenberg CS, Birckbichler PJ, Ruce RH. Transglutamınases multufunctional cross-lınkıng enzymes that stabilize tussues Faseb J 1991:5(15).3071-7

52. Km HC, Idler WW, Kum IG, Han JH, Chung SI. Steiner PM. The complere amino acid sequence of the human transglutaminase $K$ enzyme deduced from the nucleic acid sequences of cDNA clones J Biol Chem 1991,266(1):536-9.

53. Kım IG, Lee SC, Lee JH, Yang JM, Chung SI, Steinert PM Structure and organization of the human transglutamınase 3 gene: evolutıonary relationshup to the transglutaminase family. J Invest Dermatol 1994;103(2):137-42

54. Aeschlimann D, Koeller MK, Allen-Hoffmann BL, Mosher DF. Isolation of a cDNA encoding a novel member of the transglutamınase gene family from human keratinocytes. Detection and identification of transglutaminase gene products based on reverse transcription- polymerase chan reaction with degenerate primers.

J Biol Chem 1998;273(6) 3452-60

55. Lundstrom A, Egelrud T. Evidence that cell shedding from plantar stratum corneum in vitro involves endogenous proteolysis of the desmosomal protein desmogleın I. J Invest Dermatol 1990,94(2):216-20
56. Lundstrom A, Egelrud T. Cell shedding from human plantar sken in vitro evidence that two different types of protein structures are degraded by a chymotrypsin- like enzyme.

Arch Dermatol Res 1990;282(4) 234-7

57. Suzuku Y, Nomura J, Koyama J, Horı I The role of proteases in stratum corneum: involvement in stratum corneum desquamation.

Arch Dermatol Res 1994;286(5) 249-53

58. Egelrud T, Lundstrom A. A chymotrypsin-like proteinase that may be involved in desquamation in plantar stratum corneum Arch Dermarol Res 1991;283(2) 108-12

59. Hansson L, Stromqvist M, Backman A, Wallbrandt P, Carlsteın A, Egelrud T Cloning, expression, and characterization of stratum corneum chymotryptic enzyme A slun-specific human serine proteinase.

J Biol Chem 1994;269(30):19420-6

60. Franzke CW, Barcı A, Bartels ], Christophers E, Wiedow $O$. Antileukoprorease inhibits stratum corneum chymorrypuc enzyme Evidence for a regulative function in desquamation. J Biol Chem 1996:271(36):21886-90

61. Brattsand M, Egelrud T. Purification, molecular cloning, and expression of a human stratum corneum trypsin-like serine protease with possible function in desquamation J Bıol Chem 1999;274(42):30033-40

62. Suzukı Y, Nomura J, Hon J, Koyama J, Takahashı M, Horu I Detecrion and characterızation of endogenous protease associated with desquamation of stratum corneum Arch Dermatol Res 1993,285(6):372-7.

63. Ekholm IE, Brattsand M, Egelrud T. Stratum corneum tryptic enzyme in normal epidermis a missing link in the desquamation process? J Invest Dermatol 2000;114(1):56-63.

64. Horıkoshı T, Igarashı S, Uchıwa H, Brysk H, Brysk MM Role of endogenous cathepsin D-like and chymorrypsin-like proreolysis in human epidermal desquamation Br J Dermatol 1999, 141(3):453-9

65 Kawada A, Hara K, Komınam E, Hıruma M. Noguch $H$, Ishibashı A. Processing of cathepsins $L, B$ and $D$ in psoriatuc epidermis. Arch Dermatol Res 1997,289(2).87-93

66 Watkınson A Stratum corneum thiol protease (SCTP): a novel cysteine protease of late epidermal differenciation Arch Dermacol Res 1999;291(5):2608 


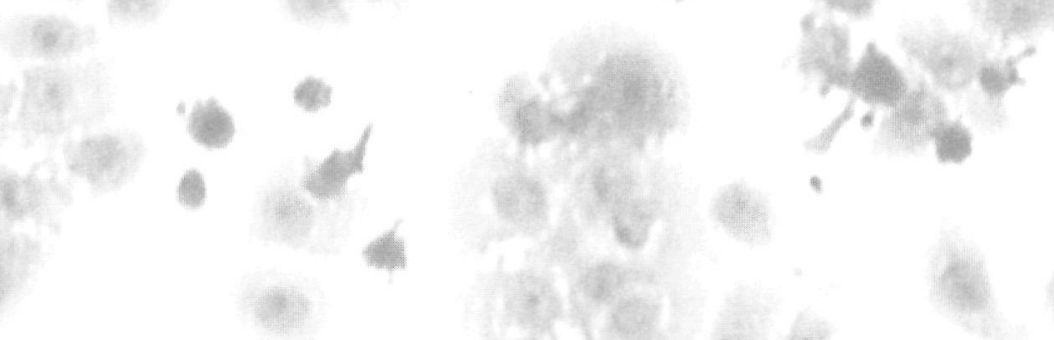

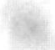

穴

34ter
ark
ats.
6ar and
CHAPTER 7

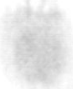

des

\section{Summary and general discussion}

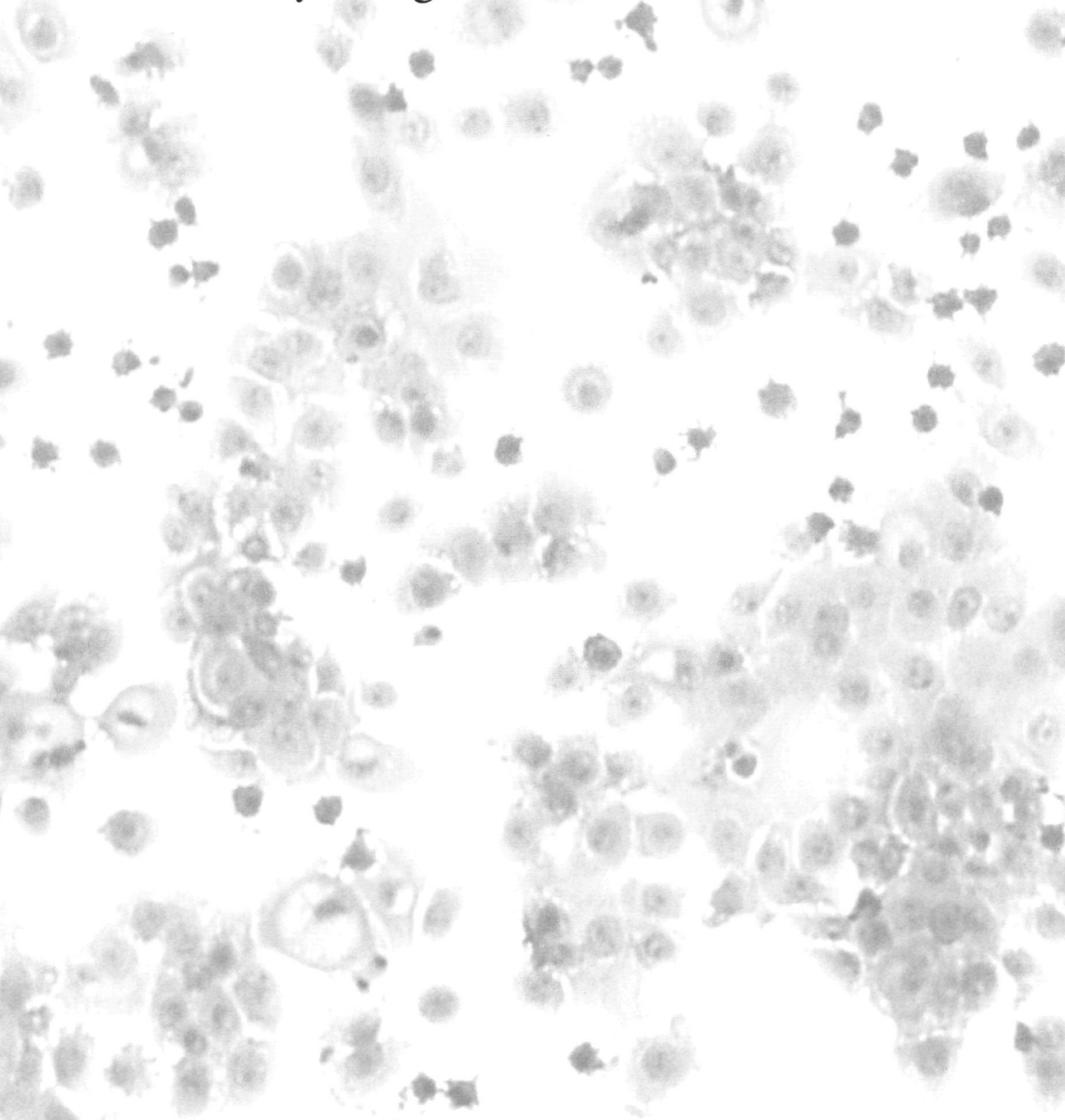



This thesis describes the application and discusses the results of SAGE in human epidermal keratınocytes, both in vitro and in vivo In CHAPTER 1 , a general overview of the molecular biology of gene expression is presented, as well as various techniques that have been developed over the course of the last three decades, which allow us to investigate (differential) gene expression SAGE is reviewed in more detall, as it was the prime technique used during the course of the project Furthermore, it provides an overview of the current state of knowledge with regard to keratinocyte-specific gene expression, as well as a comprehensive introduction to biology of TNF family members, some of which play important roles in both skin development and skin disease In CHAPTER 2, SAGE on cultured keraunocyres is described and discussed, and the expression profiles of normally differentuated and TNF- $\alpha$ stımulated keratınocytes were compared, providing a first peek into the human keratinocyte transcriptome The application of SAGE to isolated epidermis from both healthy volunteers and patients with actinic keratosis, a premalignant condition in the epidermis, is presented in CHAPTER 3 Furthermore, two-way cluster analysis was performed on libraries that were derived from both cultured keratinocytes and epidermis, providing further insight in premalignant gene expression In CHAPTER 4 a partial transcriptome of the human keratinocyte is presented, on the basis of the libraries of cultured keratunocytes that underwent normal differentiation, and healthy human epidermis One TNF family member and potent inducer of apoptosis in tumor cells, TRAIL, was identified by SAGE in cultured keratınocytes Its effect on undifferentiated and differentiated keratinocytes is described in CHAPTER 5, and it is shown that the response is differentiationdependent, and does not involve DNA fragmentation In CHAPTER 6, the expression, tissue distribution and biological properties of another gene, cystatın $M$, is described Cystatın $M$ was first identified by SAGE in cultured keratinocytes, and may play a role in anti-microbial host defense

In a well-establıshed keratınocyre culture model, the effect on gene expression of prolonged TNF- $\alpha$ stimulation was investigated at the level of mRNA expression, resulting in two SAGE libaries which together represented more than 25,000 transcripts, potentially encoding more than 10,000 genes Comparison of the librarıes revealed that approximately $1 \%$ of the genes are differentially regulated Regardless of stımulation, cultured keratınocytes put a huge effort in the expression of genes that are involved in differentiation and barrier formation, as $6 \%$ of all tags identified corresponded to this class of genes, ind,catıng that cultures are indeed differentiated Furthermore, $2 \%$ of all tags accounted for 
genes that are potentially involved in host defense, such as proteinase inhibitors and antimicrobial proteins. Some of these, such as cystatin $M$, were not known to be expressed in keratinocytes, whereas others appeared to be regulated by TNF- $\alpha$. Another important class of genes that is expressed is the one that is involved in apoptosis. Most notably, TRAIL and its death receptor TRAIL-R2 are expressed, and both are family members of the TNF and TNFR superfamilies, respectively. Also, various mediators of survival are expressed in keratinocytes, probably neutralizing any effect of death initiators and mediators. SAGE on cultured keratinocytes provided a wealth of data that represented the first glimpse of the keratinocyte transcriptome. Roughly $10 \%$ of differentially regulated tags could not be assigned to known genes, but many of these may be derived from known transcripts as a result of alternative polyadenylation or alternative splicing. Although initial attempts failed to identify corresponding genes, new and improved protocols have now sparked a new initiative to isolate keratinocyte-specific genes (CHAPTER 2).

Application of SAGE to human epidermis and epidermis from patients with actinic keratosis required some adapatations. First, to prevent contamination of other tissues, normal and affected epidermis was enzymatically separated from the dermis with dispase. This technique works very well, as the expression of differentiation markers do not seem to be disturbed. Still, minute amounts of other cell types (primarily melanocytes and Langerhans cells) may be present, but they are not considered a nuisance as they are by far outnumbered by keratinocytes. Second, epidermal samples are small and required the use of an adapted protocol, called MicroSAGE, which can handle as little as $100 \mathrm{ng}$ toral RNA. In order to analyze SAGE data, two-way cluster analysis was performed, which revealed clusters of genes that are associated specifically with either normal epidermis, actinic keratosis or cultured keratinocytes, and uncovered clear partitions and correlations that could be confirmed by independent methods. Automated literature search tools showed that a subgroup of these genes is known to be co-expressed in other tissues, and is part of an epidermal differentiation gene cluster on chromosome $1 \mathrm{q} 21$. The identified partitions and correlations will lead to biological interpretations that can be relevant for understanding the processes of carcinogenesis and tumor progression. Furthermore, SAGE data can be used to design cDNA micro-arrays, as clusters of co-regulared genes, be it in normal homeostasis or disease, can positively correlate to a certain phenorype, and thus serve as a diagnostic parameter (CHAPTER 3).

When data from the SAGE libraries of differentiated cultured keratinocytes and normal human epidermis are combined, one can effectively speak of a (partial) transcriptome for human epidermal keratinocytes, as the data reveal which genes can potentially be expressed in these cells. Moreover, and perhaps just as important, one can compare the in vitro and in vivo SAGE data, in order to determine to what extent the culture system truly mimicks normal epidermis in terms of gene expression. It was already evident from cluster analysis that there is a clusters of genes of which the expression is specific for cultured keratinocytes or human epidermis. 15,000 tags from human epidermis, potentially representing more than 7,500 genes, were analyzed. Interestingly, keratinocyte-specific genes that are involved in barrier formation and differentiation are not as highly expresssed in human epidermis as in cultured keratinocytes, whereas epidermal keratinocytes in vivo use more of their resources for the expression of housekeeping genes, most notably those that are involved in protein synthesis. Although cultured keratinocytes show differences in expression pattern when compared with human epidermis, transcription profiles once again confirm that the model mimicks differentiating keratinocytes, as differentiation markers specific for this type of cells are abundantly expressed. Many unknown tags were discovered, several of 
which appear to be keratınocyte-specific, and may account for genes that were previously unknown The data provide a wealth of information about genes that may be involved in skun function, and may prove instrumental in the identification of candidate genes for heritable skin diseases (CHAPTER 4)

One of the interesting genes that was found to be expressed in cultured keratinocytes was TNF-related apoptosis inducing ligand (TRAIL), and its expression was also confirmed for human epidermis For this gene 5 tags were found in the combined SAGE libraries from cultured keratinocytes, raising questions about its function Interestingly, its death receptor, TRAIL-R2, is also expressed in cultured keratınocytes TRAIL is known to induce apoptosis specifically in cancerous cells, although there is evidence that it is also capable of inducing a suicidal pathway in completely healthy, human liver cells To assess its effect on cultured keratınocytes, TRAIL was added to undifferentiated and differentiated keratınocyte cultures It appears that TRAIL induces receptor-mediated apoptosis through caspase-8 and caspase-3 activation in human cultured keratınocytes However, differentiated cultured keratınocytes have a much lower sensitivity, whereas prolıferatıng keratınocytes rapidly undergo apoptosis upon stimulation by TRAIL One of the classical features of apoptosis is nuclear condensation and DNA fragmentation, the latter of which can be visualized by means of agarose gel electrophoresis and analyzed by propidium ıodide staining followed by flowcytometry Unexpectedly, attempts to prove this typical feature falled, due to the virtual absence of the enzyme responsible for DNA fragmentation, DNA fragmentation factor of $40 \mathrm{kDa}$ (DFF40) It is speculated that this particular feature in apoptosis is present in cells that have a high proliferative capacity, and that minute amounts found at the mRNA level may be derived from stem cells These cells should be able to execute a fast suicidal pathway in the event of a toxıc challenge, thereby minımızıng potentıally detrımental effects on the host Terminally differentiating keratınocytes, however, execute a much slower type of programmed cell death without displaying the typical nuclear condensation and DNA fragmentation These cells are unable to proliferate, and there is litcle chance they will develop into potential tumor cells upon a genotoxic stımulus Therefore, they do not need the armament to die rapidly, and other, as of yet undetermıned, mechanısms take care of the disposal of the nucleus Our findings once agan do challenge the notion that TRAIL only attacks cancerous cells, rasing serious questions about its effects during anti-cancer therapy Endogenous TRAIL does not seem to induce cell death, and further research is needed to investigate its role in skın biology (CHAPTER 5)

The human skin also harbors a wide range of proteins that are potentially involved in innate immunity and host defense against microbes One of these is cystatin $M$, which was first identified in SAGE libraries derived from cultured keratınocytes Immunohistochemical analysis revealed that it is exclusively expressed in the stratum granulosum of the human epidermis, in har follicles and eccrine sweat glands Furthermore, cystatin $M$ is a substrate for transglutaminase and can be crosslinked to other proteins in the stratum corneum, highly suggestive of a role for this protein in the inhibition of non-self proteases Cystatin $M$ expression is induced in culture by differentiation, consistent with its presence in differentrated layers in vivo The protein contains a signal pepude which suggests that it is excreted from the cell, which is indeed the case in vitro, as it was found in the culture supernatant, as well as in vivo in sweat Interestingly, several lysosomal proteinases were tested as a subtrate for cystatın $M$, but none showed dramatic inhibition by the inhibitor These data at least indicate that cystatin $M$ is not directed against known, physiologically relevant proteases, but probably agaunst other self or non-self cysteine proteınases that remain to be identified (CHAPTER 6) 
SAGE has proven instrumental in the analysis of gene expression relevant to epidermal keratınocytes in the broadest sense It has allowed us to identify genes that may play important roles in human cutaneous biology, and has spurred still ongoing research into the function of some of these genes Furthermore, it has allowed us to pinpoint clusters of genes that may be relevant in the onset of malignant transformation in actinic keratosis, and to those that are associated with abnormal proliferation The next obvious step is of course to isolate those genes that are specific to keratınocytes, actinic keratosis and TNF- $\alpha$. stimulated keratinocytes Although initial attempts to isolate genes on the basis of their tag sequence have fauled, new and improved protocols have been developed that may aid in this process Although SAGE does in principle allow the identification of specific transcripts, there is still a possibility that some are being missed by the simple fact that their cDNAs do not contain a recognition sequence for the anchoring enzyme This holds especrally true for cDNAs derived from small mRNAs There is no real solution to this drawback other than that one can construct an additional SAGE library in which another anchoring enzym is used, but this is both time-consuming and expensive An additional problem that may be more of a nuisance is that some genes are represented by more than one tag, some of which have not (yet) been linked to that gene in the UniGene database Such tags have been found in the libraries presented in this thesis, and although their presence raises interesting questions regarding pre-mRNA processing in response to a stimulus or a condition, they also 'pollute' the data An example is the gene for laminın- $\beta 2$, of which two different splicing variants are known in which the coding sequence is not affected One of the variants is differentially expressed, and upregulated by TNF- $\alpha$, whereas the other is not Yet SAGE is a powerful rechnology with regard to the amount of genes that can be analyzed at simultaneously, and provides information that can be used in microarray based methods to investıgate differentıal gene expression As such, it perfectly complements other existing tools to investigate gene expression, and is the technology of choice for expression profiling of small samples Furthermore, it potentially catalyzes functional research in (sets of) genes that play an important role in the skun and associated diseases Hopefully, this thesis has shown to what extent SAGE has and will have an impact on the knowledge we have of the human skun, and that SAGE is useful, alıve and kuckung 


De humane huid bestaat uit een lederhuid (dermıs), waarover een gelaagd weefsel ligt Dit gelaagde weefsel, de epıdermıs, bestaat voornamelık uit keratınocyten, cellen die door een complex proces van veranderıngen zorg dragen voor de vormıng van de barrière tussen het milieu en het menselıjk lichaam Dat proces van veranderingen wordt differentiatie genoemd, en wordt gekenmerkt door de overgang van delende keratınocyten in de binnenste, basale laag van de epidermis naar terminaal gedifferentieerde keratınocyten of corneocyten, die een ondoordringbaar netwerk van eiwitten en vetten vormen en zo uiteindelık de dode, stevige, buitenste hoornlaag vormen van onze huid Aan deze differentiatie ligt een complex proces van gen-expressie ten grondslag Bij huidziekten als psoriasis, een ziekte die wordt gekenmerkt door een chronisch ontstoken huid, is dit proces ontspoord, waardoor de normale gelaagde structuur verloren gaat en er voornamlıjk actıef delende, prolıfererende keratınocyten in de zıeke huid aanwezıg zıjn, alsmede een infiltraat van immuuncellen Een andere aandoening van de epidermis, actinische keratose, wordt ook gekenmerkt door een ontspoorde differentiatie in epidermale lesies, met het verschil dat deze lesies ook kunnen ontaarden in kwaadaardige plaveiselcel-carcınomen Psorıasıs komt voor by ongeveer $2 \%$ van de bevolkung Actinische keratose komt voor op huid die lang aan UV straling blootgesteld is geweest en bij patienten, die een niertransplantatie hebben ondergaan en immunosuppressiva gebruiken om afstotıng van de nier te voorkomen

De eerste stadıa van differentıatıe kunnen in een celkweekmodel worden nagebootst, en zodoende kan het effect van stoffen op de gen-expressie van differentierende keratinocyten worden onderzocht Genen die coderen voor een elwit worden eerst overgeschreven in een boodschapper RNA (mRNA), dat vervolgens wordt getransporteerd naar een van de ribosomen, de eiwitfabriekjes van de cel, alwaar het vertaald wordt in een eiwit Boodschapper RNA's komen al naar gelang de situatie in verschillende hoeveelheden, of wel of niet tot expressıe Recentelıjk 2ıjn technologieen ontwıkkeld die het mogelık maken om de expressıe van letterlıjk duizenden genen regelıjk te onderzoeken Eén daarvan, Serıal Analysis of Gene Expression (SAGE), is hier toegepast om verschillen in gen-expressie te onderzoeken in gekweekte, gedifferentieerde keratınocyten en gedifferentieerde keratınocyten die zıjn blootgesteld aan tumor necrosıs factor $\alpha$ (TNF- $\alpha$ ), een belangrıjke mediator in de ontstekingsrespons bij psoriasıs SAGE is gebaseerd op het principe dat de kennis van slechts een kleın deel van een sequentıe van een gen dat afkomstıg is van een gedefinieerde plaats in het gen, voldoende is om een mRNA voor dat gen te identificeren Wanneer deze kleıne stukjes sequentie (tags) serıeel kunnen worden geanalyseerd, verkrıgt 
men niet alleen informatie over welke genen (kwalitatief), maar ook in welke mate elk gen (kwantıtatief) actief is. SAGE heeft onder andere aangetoond dat keratinocyten meer dan 12,000 genen rot expressie kunnen brengen, en dat vele genen tot expressie komen die geassocieerd zijn met differentiatie van keratinocyten. Slechts een kleine hoeveelheid, ongeveer $1 \%$, van de genen wordt daadwerkelijk gereguleerd door TNF- $\alpha$. Tevens investeren deze cellen veel in de expressie van genen die mogelijk een belangrijke rol spelen bij een anti-microbiële respons, een belangrijke noodzakelijke eigenschap voor huidcellen, aangezien zij zich op de grens van het milieu en het organisme bevinden. De expressie van een aantal van de laatstgenoemde genen wordt overigens gestimuleerd door TNF- $\alpha$, hetgeen kon worden bevestigd met andere onafhankelijke technieken.

Daarnaast is een aangepaste vorm van SAGE, MicroSAGE, toegepast op kleıne biopten van de huid. MicroSAGE is speciaal ontwikkeld voor de analyse van kleine samples. Hiermee hebben wij normale epidermis vergeleken met aangedane epidermis van patiènten met actinische keratose. Clusteranalyse heeft uitgewezen dat groepen van genen onder specifieke omstandigheden tot expressie komen. Zo komen bij actunische keratose genen tor expressie die ook in andere ziektes tot expressie komen, zoals psoriasis en kanker, waarbij een ontregelde differentiatie gepaard gaat met overmatige celdeling. Mogelijk spelen deze genen in het algemeen een belangrijke rol bij ontspoorde differentiatie. Een subgroep van deze genen kon verder worden geïdentificeerd door middel van geautomatiseerde literatuuranalyse, waaruit bleek dat deze genen ook ge-coreguleerd worden in andere weefsels, en alle liggen in een cluster op chromosoom lq21. Correlaties tussen gen-expressie profielen leiden hopelijk to meer inzicht in de biologie van de huid en van huidziekten. Clusteranalyse heeft aangetoond dat er wel degelijk verschillen zijn tussen het kweekmodel en de humane huid. Dat cellen in kweek blijken te differentieren, blijkt vooral uit het feit dat genen die daarbij een rol spelen zeer hoog tor expressie komen. In de humane epıdermis komen vooral genen tot expressie die een rol spelen bij eiwitsynthese. De data geven voor het eerst een indruk van het repertorre van genen dat in humane keratinocyten tot expressie komt, en vormt zo een index die ook wel transcriptoom wordt genoemd.

Twee genen zijn onderworpen aan verder functioneel onderzoek. D.m.v. SAGE is TNFrelated apoptosis inducing ligand (TRAIL) geidentificeerd in gekweekte keratinocyten, maar het blijkt ook tot expressie te komen in humane huid. TRAIL induceert geprogrammeerde celdood in delende keratinocyten, maar nauwelijks in cellen die zijn gecommiteerd aan terminale differentiatie. Fragmentatie van het erfelijk materiaal uit de celkern, een van de eigenschappen van de celdood zoals die door TRAIL wordt geïnduceerd in tumorcellen, blijkt echter door de afwezigheid van het enzym dat daarvoor verantwoordelijk is, achterwege te blijven. Dit verklaart mogelijkerwijs ook waarom tijdens geprogrammeerde celdood ten gevolge van terminale differentiatie dit fenomeen achterwege blijft, en hiermee is voor het eerst ook duidelijk een verschil blootgelegd tussen de twee rypen celdood. Verder onderzoek is momenteel gaande om de rol van TRAIL in de huid verder uit te diepen. Een ander gen dat is onderworpen aan een nadere funcrionele studie is cystatin $M$. Het eiwit is een remmer van cysteïne proteasen, hoewel nog niet bekend is welk protease het substraat is. Het blijkt niet alleen in kweek tot expressie te komen, maar heel specifiek in de hogere lagen van de humane huid en in zweetkdieren. Het komt ook voor in de hoornlaag, hetgeen suggereert dat het een rol speelt in de bescherming van de huid, mogelijk tegen proteasen die een rol spelen bij microbiële infectie. Ook cystatin $M$ is momenteel onderwerp van verdere functionele studies. 
SAGE heeft een schat aan data opgeleverd die ons een beter inzicht geven over genexpressie in de huid, en derhalve in huidbiologie en pathologie. Ondanks de nadelen die kleven aan SAGE, heeft het reeds geleid tot de identificatie van genen waarvan tot voor kort niet bekend was dat ze in keratinocyten tot expressie kwamen, en heeft dien ten gevolge de aanzet gegeven tot verder onderzoek. Vele van de geïdentificeerde tags kunnen (nog) niet worden gekoppeld aan bekende genen, en momenteel worden pogingen ondernomen om deze alsnog te isoleren en identificeren. Daarnaast kunnen data worden gebruikt om genen te identificeren die mogelijkerwijs betrokken zijn bij erfelijke ziekten. SAGE is een krachtige technologie, en genereert data die kunnen worden aangewend voor andere vormen van gen-expressie profilering, zoals micro-array analyse. MicroSAGE is vooralsnog de enige technologie die adequaat expressie-profielen kan genereren van zeer kleine weefselmonsters. SAGE is niet dood, maar springlevend. 


\section{List of Abbreviations}

2D-PAGE 2-dimensional polyacrylamide gel electrophoresis

AK

C/EBP- $\alpha$

cDNA

CE

cFLIP

CK

CTWC

DD-PCR

DFF

DISC

EST

GST

hARP-P0

IHC

JNK

KBM

KGM

LPS

MAPK

mRNA

MRP

NCBI

NF-kB

NMSC

PA-FABP

PCR

RACE

RDA

rRNA

RT-PCR

SAGE

SCC

SCCE

SCTP

SKALP

SLPI

SSH

TGase

TNF- $\alpha$

TNFR

TRAIL

TRAIL-R

UTR

UV
Actinic keratosis

CCAAT-enhancer binding prorein alpha

Copy DNA

Cornified cell envelope

FADD-like inhibitory protein

Cytokeratin

Coupled two-way clustering

Differential display polymerase chain reaction

DNA fragmentation factor

Death inducing signaling complex

Expressed sequence tag

Glutathion S-transferase

Human acidic ribosomal protein P0

Immunohistochemistry

c-Jun terminal kinase

Keratinocyte basal medium

Keratinocyte growth medium

Lipopolysaccharide

Mitogen-activated protein kinase

Messenger RNA

Migration inhibitory factor-related protein

National Center for Biotechnology Information

Nuclear factor kappa beta

Non-melanoma skin cancers

Psoriasis-associated fatty acid binding protein

Polymerase chain reaction

Rapid amplification of cDNA ends

Representational differenence analysis

Ribosomal RNA

Reverse transcriptase polymerase chain reaction

Serial Analysis of Gene Expression

Squamous cell carcinoma

Stratum corneum chymotryptic enzyme

Stratum corneum thiol proteinase

Skin-derived antileukoproteinase

Secretory leukoprotease inhibitor

Suppression subtractive hybridization

Transglutaminase

Tumor necrosis factor alpha

TNF receptor

TNF-related apoptosis inducing ligand

TRAIL receptor

Untranslated region

Ultraviolet 


\section{List of publications}

Van Strien, E A , Jansen, B J H , Mans, R.M.W., Zuidema, D, Vlak, J M

Sequence and transcriptional analysis of the ubiquitin gene cluster in the genome of Spodoptera exigua nucleopolyhedrovirus.

J Gen Virol 1996,77(Pt 9) 2311-9

Jansen, B J H , van Ruissen, F., de Jongh, G, Zeeuwen, PL J M , Schalkwiłk, J

Serial analysis of gene expression in differentiated cultures

of human epidermal keratinocytes.

J Invest Dermatol 2001,116(1) 12-22

Zeeuwen, PL J M , van Vlımen-Wıllems, I M J J , Jansen, B J H , Sotıropoulou, G , Curfs, J H , Mess, J FG M, Janssen, J J M, Van Ruissen, F, Schalkwık, J.

Cystatin $M / E$ expression is restricted to differentiated epidermal keratinocytes and sweat glands: a new skin-specific proteinase inhibitor that is a target for cross-linking by transglutaminase.

$J$ Invest Dermatol 2001,116(5) 693-701

Van Ruissen, F, Jansen, B J H , de Jongh, G J , van Vlıjmen-Willems, I M J J , Schalkwıkk, J

Differential gene expression in premalignant human epidermis revealed by cluster analysis of serial analysis of gene expression (SAGE) libraries. FASEB J 2002,16(2) 246-8

Van Ruissen, F, Jansen, B.J H., de Jongh, G J., Zeeuwen, PL J M , Schalkwı1k, J A partial transcriptome of human epidermis.

Genomics In press

Jansen, B J H , Van Russen, F., Cerneus, S , Cloin, W, Bergers, M, Van Erp, PE J , Schalkwiłk, J

TNF-related apoptosis inducing ligand (TRAIL) triggers apoptosss in human epidermal keratinocytes in the absence of internucleosomal DNA fragmentation.

Submutted 


\section{Dankwoord}

Het schrıven van een proefschrift doe je grotendeels alleen, maar de totstandkoming ervan kan uiteraard niet plaatsvinden zonder de hulp van anderen Toen $1 \mathrm{k}$ in julı 1997 begon aan het SAGE project, dacht $\mathrm{k}$ dat varkentje wel even te kunnen wassen $\mathrm{Na}$ behoorlıjk wat ervaring te hebben opgedaan in molecular-bıologısche technieken tıdens mijn studie in Wagenıngen en mın werk in Los Angeles, leek SAGE een relatıeve peulenschil aangezien het fertelıjk op klassieke technieken is geschoeid De werkelıjkheıd bleek hard. Mijn geluk was dat $1 \mathrm{k}$ er nuet alleen voor stond. Het 'SAGE Team', bestaande uit mızelve, Fred van Ruissen, Gys de Jongh, en dat werd geleid door mijn co-promotor Joost Schalkwijk, heeft menigmaal de nachtrust niet kunnen vatten vanwege schijnbaar onverklaarbare technische problemen Terugkj,kend verbaas $\mathbf{k}$ me erover dat wı het toch maar geflıkt hebben, en $\mathrm{kk}$ ben ervan overtuigd dat het allemaal niet mogelık was geweest als we elkaar niet zo hadden gesteund Er zıjn waarschıjnlık veel mensen die in onze sıtuatıe na 3 maanden de handdoek in de rıng zouden hebben gegooid Ik heb de samenwerkng bınnen het SAGE team altıd bızonder prettıg gevonden, en $\mathrm{k}$ wil jullıe, Fred, Gys en Joost, daarvoor hartelıjk danken Een speciaal woord van dank rıcht ik tot jou, Joost, voor de gelegenheid die je mij hebt geboden om het project uit te voeren $\mathrm{J}_{\mathrm{l}}$ hebt vertrouwen gehad in SAGE en de mensen die eraan werkten, en zonder dat vertrouwen hadden we er noott rets van kunnen bakken, laat staan dat dit proefschrift voltooıd had kunnen worden Hopelıjk kunnen we de komende tıjd nog meer uıt SAGE halen! Tevens wil ik mijn promotor, prof. dr. dr. Peter van de Kerkhof, uitdrukkelıjk en hartelıjk danken voor zijn interesse en hulp bij het tot stand komen van dit proefschrif. Vooral in de laatste fase van het promotietraject heb je je bijzonder ingezet, en de directe communicatie tussen ons heb $\mathrm{k}$ altıj als zeer prettıg ervaren Wie niet in de dankzeggingen mogen ontbreken zujn de mannen van 'de sectie Genodermatologıe', Reno, Maurice, Michel en Peter Steijlen, die altıjd oprecht geinteresseerd zıjn geweest in mijn promotie-onderzoek, en met wie ık van tıjd tot tıjd 'nabeurs' wel eens een biertje kap Hopelık volgen er nog vele Verder wil $ı$ alle andere collega's, analisten en studenten, bedanken voor de steun voor en interesse in het SAGE project Mıjn zus Caroline en broer Bart wil ik hartelıjk danken voor de aanvaardıng van de rol van paranımf bıj mıjn promotıe Jullıe zıjn denk $\mathbf{k}$ nog nooıt zo dıcht betrokken geweest bıj een promotie, en $\mathrm{k}$ hoop dat jullıe er met plezier aan terug zullen denken Ik in ıeder geval wel' Ik ben Wilma van Wijnen heel dankbaar dat ze me, in de aanloop naar de promotie, de opmaak van mijn proefschrift uit handen heeft kunnen nemen Het is buitengewoon fraa geworden, $\mathrm{tk}$ ben er heel trots op

Promoveren doe je niet alleen, maar het traject dat eraan voorafgaat is mede bepalend geweest voor de uiteindelıje keuzes die je maakt Dat traject had ik nooit kunnen doorlopen zonder de niet aflatende steun die $\mathrm{k}$ van mijn moeder, de 'mater familıa', heb mogen ontvangen Ik ben $U$ er ontzaglıjk dankbaar voor dat $U$ mı in de gelegenheıd hebt gesteld de studie te kunnen volgen die ık voor ogen had, en ben $U$ ontzettend dankbaar voor de morele steun die $U$ gedurende mijn studie en promotse heeft gegeven. Ik weet zeker dat $\mathrm{k}$ het zonder $U$ miet had gered Dat meen ik

Tja, en dan is daar natuurlıjk Miriam, mın Mırıam, dıe mın nukken ten gevolge van mıjn promotie heeft moeten trotseren, maar die mij wel heeft gestımuleerd om door te gaan op momenten dat $\mathrm{k}$ er geen zin meer in had Alleen ju weet hoe die momenten, wanneer $\mathrm{k}$ er flınk de pest in had, waren, en $\mathrm{k}$ weet eerlıjk nıet hoe $\mathrm{kk}$ je moet bedanken voor je geduld, steun en warmte Keibedankt, moppie' 


\section{Curriculum Vitae}

Bastiaan Jan Herman Jansen werd op 4 april 1970 geboren in Boxtel, waar hij tot en met 1988 heeft gewoond Vanaf 1982 doorliep hı het gymnasıum- $\beta$ aan het plaatselıke Jacob Roeland Lyceum, alwaar hij in 1988 zijn diploma haalde In september van dat jaar begon hij vervolgens met de studıe Planteziektenkunde aan de Landbouwuniversiteit in Wageningen, en heeft hij met succes het propaedeutisch examen in 1 jaar gehaald Vrıjwel onmiddelıjk heeft hij toen gekozen voor de molecularr-bıologische/fysiologische orientatie binnen die studie Het eerste afstudeervak werd doorlopen bıj de Cowpea Mosac Virus (CPMV) groep binnen de Vakgroep Molecularre Bıologie, onder leidıng van dr ir Joan Wellınk, alwaar hij onderzoek heeft gedaan naar de koppeling van transcriptie en translatie van CPMV Verder heeft hij stage gelopen bij de AIDS virus groep onder directe leıdıng van dr Terry McNearney in het lab van prof dr Lee Ratner, Department of Molecular Microbıology van de Washington University School of Medicine in St Louıs, Missourı Daar heeft hij de relatie tussen sequentie-heterogeniteit van het HIV Nef gen en stadium van ziekte onderzocht $\mathrm{Na}$ terugkeer in Nederland heeft hij onder leiding van $\mathrm{dr}$ ir Bep van Strien, in het laboratorium van prof dr Just $M$ Vlak, het ubiquitine gen en omliggende sequenties van het genoom van het Spodoptera exigua multicapsid nucleopolyhedrovirus (SeMNPV) geanalyseerd Tevens heeft hij tıdens zijn studie diverse bestuursfuncties vervuld binnen de studievereniging Planteziektenkunde In junı 1995 behaalde hij zıjn doctoraal (Ir), en vertrok een aantal maanden later naar het Children's Hospıtal of Los Angeles, alwaar hı zın horizon op het gebied van de molecularre genetıca heeft verbreed Na terugkeer in Nederland begon hij op 1 julı 1997, onder leiding van co-promotor dr Joost Schalkwisk en promotor prof dr dr Peter C M van de Kerkhof, op de afdelıng Dermatologie van het Universitair Medısch Centrum St Radboud aan het promotie-onderzoek dat heeft geresulteerd in dit proefschrift Als promovendus is hi) tevens actief geweest in de $\mathrm{PhD}$ commmissie van de onderzoeksschool 'Institure of Cellular Signaling' (ICS) Momenteel werkt hij als post-doc aan de afdelıng waar hij zijn promotieonderzoek heeft afgerond 


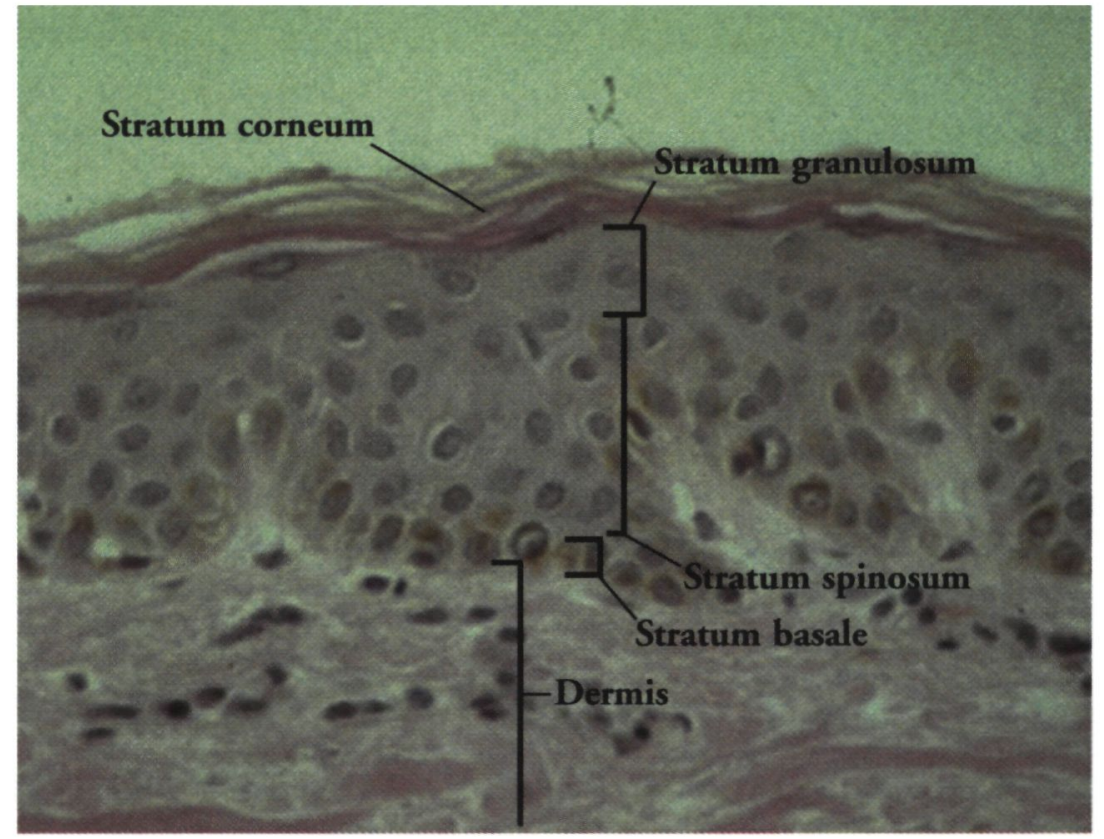

CHAPTER I - FIGURE 6, PAGE 27

$4 \mathrm{~mm}$ punch biopsy

of human skin
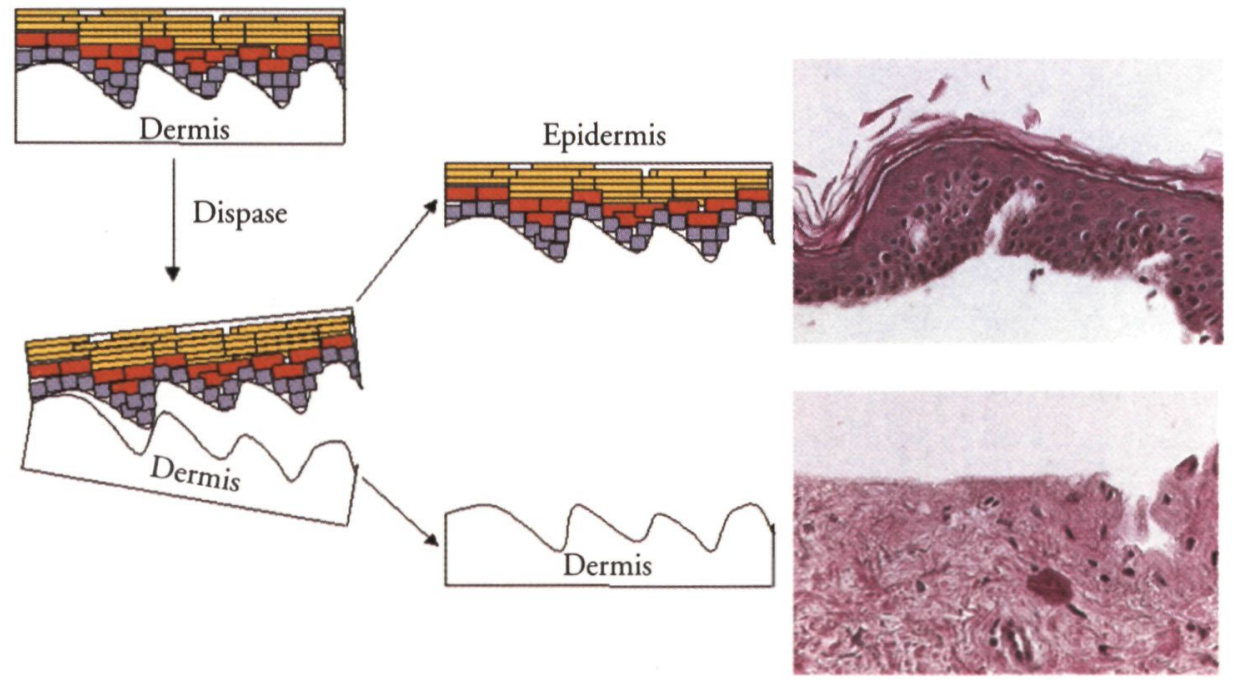

CHAPTER 4 - FIGURE I, PAGE 99 
A

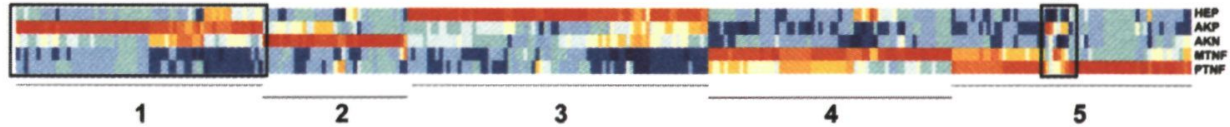

1

CHAPTER 3 - FIGURE I, PAGE 8I

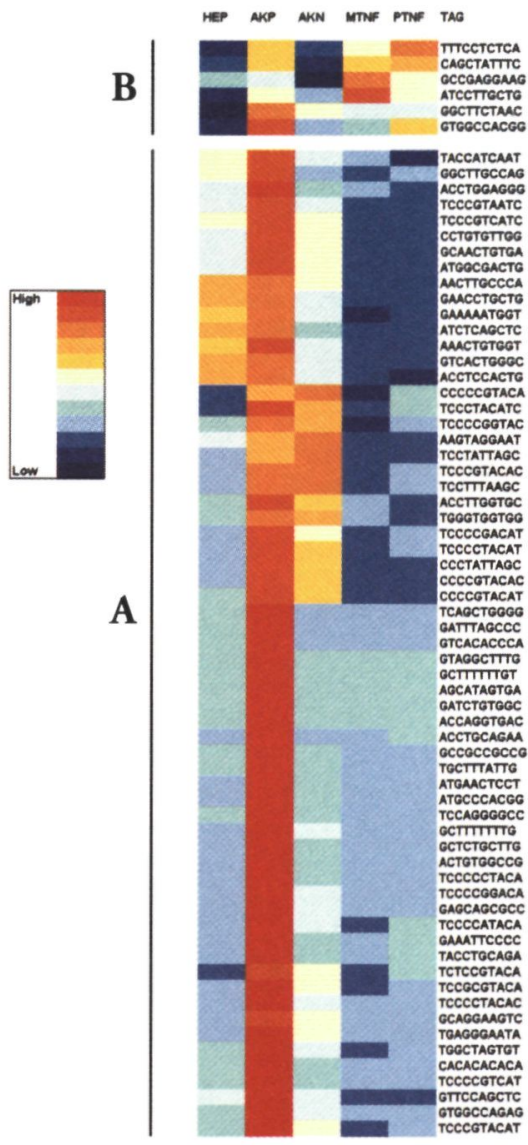

CHAPTER 3 - FIGURE 2, PAGE 83

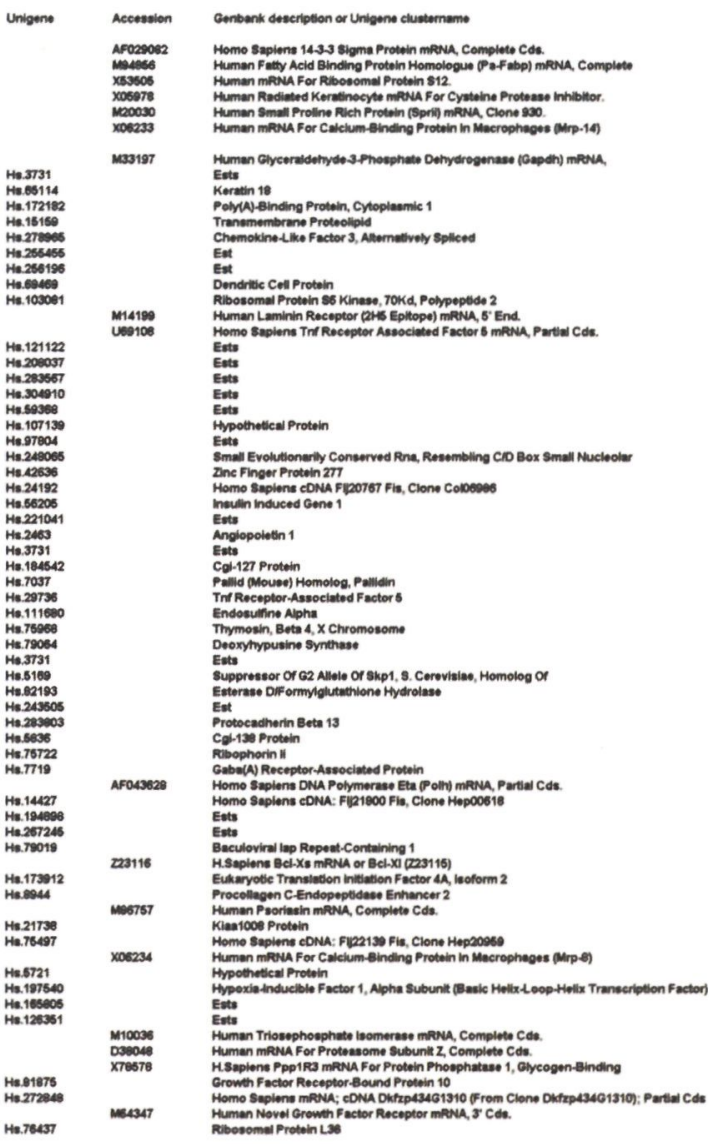

Genbenk description or Unigene cluatername

Homo sapiens 14-33 sigma Protein meNa, Complete Cda. Human Fatty Acid Binding Protoin Homologue (Pafabp) menta, Complete Aumanmench For Ribosomed Protoin s12.

Cysteine Protease inhibltor. Clana clone 390 .

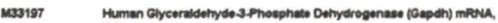

Ests

Poty(1) Binding Protoin, Cytopiasmic 1

Trensmembrene Proteollipid

Chemokine-Like Factor 3, Atornetively Sollced

Est

Dendritic Cell Protein

Ribosomal Protein 58 Kinasp, 70Kd, Polypeptide 2

M14190 Human Laminin Rocoptor (2H) Ep Eptope) mRRA 5 ' End.

Homo sapiens Tn/ Receptor Associated Factor 5 mReNa Parts Cos.

Eats

Eats

Esta

Eat:

Hypothestical Protein

Small Evolutionerly Conserved Rina, Resembiling CIO Box Smatl Nucleolew Zne Finger Protain $2 \pi$

767 Fis, Clone Colobes

insulin induced Gene 1

Esto

Anglopoletin 1

Eato

Col-127 Protein

Pallid (Mouse) Homolog, Palideln

Tnt Receptor-Associatod Factor 6

Endosumno Alpha

Thymosin, Beta 4 X Chromosome

Deoxytypusine Synthese

Eats

Suppressor Or G2 Allele Of Skp1, 3 . Cerevisien, Homolog Of

Esterase Diformylgiutathione Hydrolaso

Est

Protocadhorin Beta 13

Robophorin II

Gabe(A) Roceptor-Associated Protein

AF043628 Homo Sapiens DNA Polymerase Eta (Polly) mRen Partas Cda.

Homo Saplens CDNA: Fin21800 Fia, Clone Hep00618

Eat:

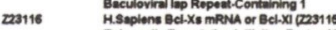

Eukaryote Transisoon inideson Fector 4A, leoform 2

First39 Fis, Clone Hepeoses

Humen meeva For Calcium - Einding Protein in Mecropheges Mrpef

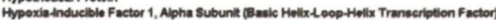

Est:

Human Triosephosphate isomerase merva, Complete Case.

Human mewe For Protosasome Subunik Z Complete Cds.

H. Saplene Ppp1F3 mReNa For Protein Phosphatase 1, Olycogen-Binding

Growth Factor Receptor Bound Protein 10

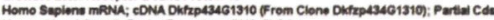
Human Novei Growth Factor Receptor maNA, 3 C Co.

Rebosomet Protein La 
NOTES 
NOTES 
B

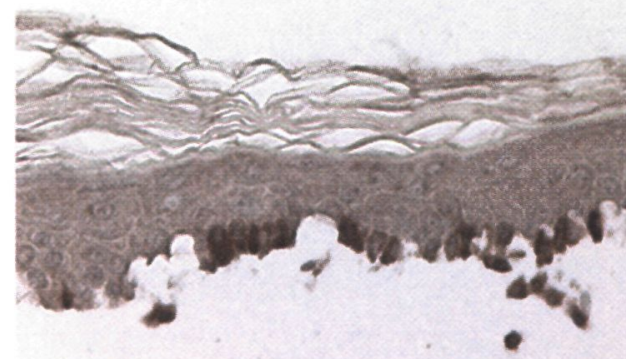

A
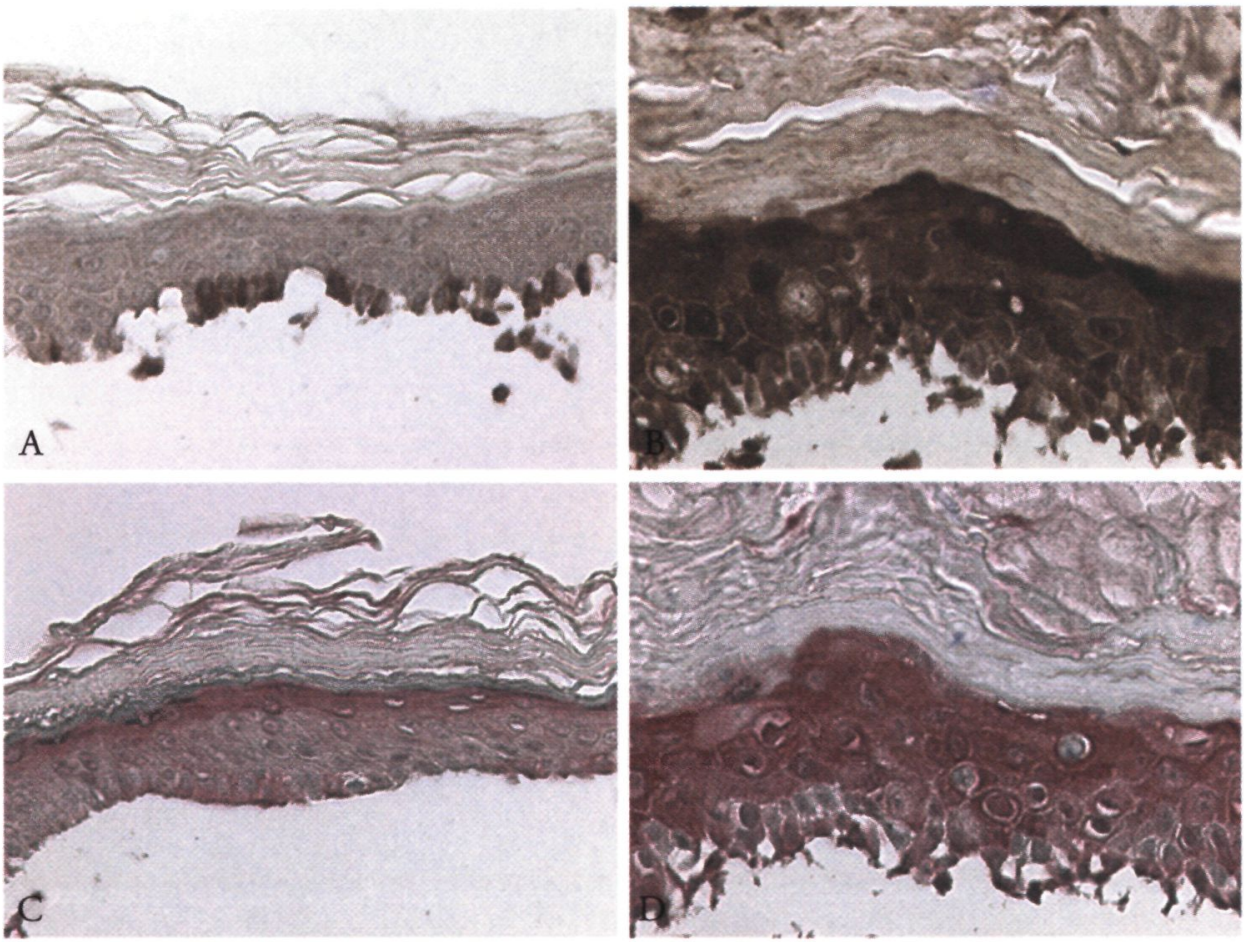

CHAPTER 3 - FIGURE 3B, PAGE 84

Neg $63 \mathrm{ng} \quad 250 \mathrm{ng}$

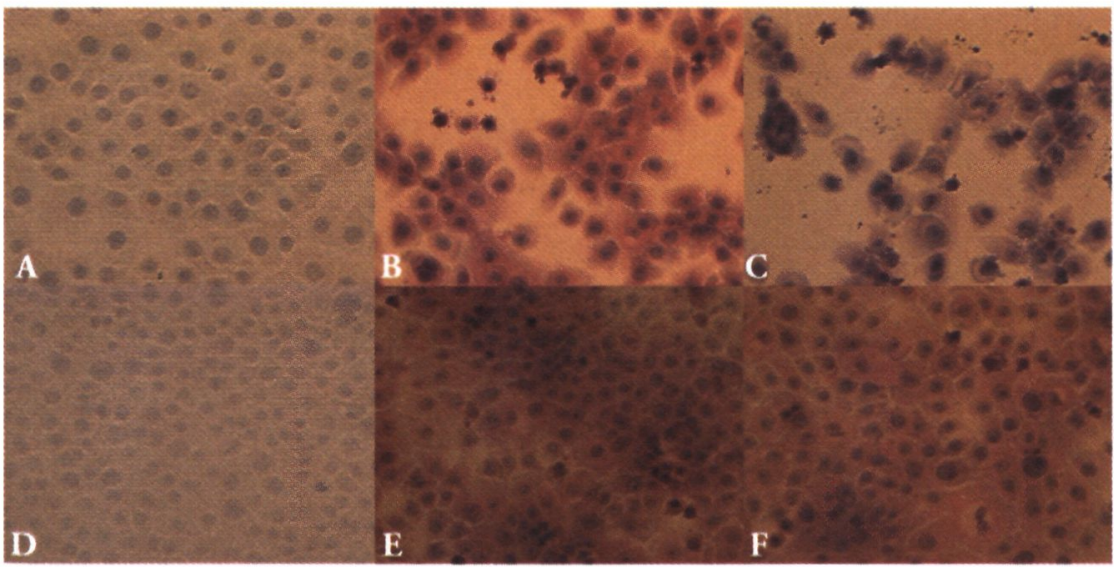

Undifferentiated

Differentiated

CHAPTER 5 - FIGURE 2, PAGE II8 

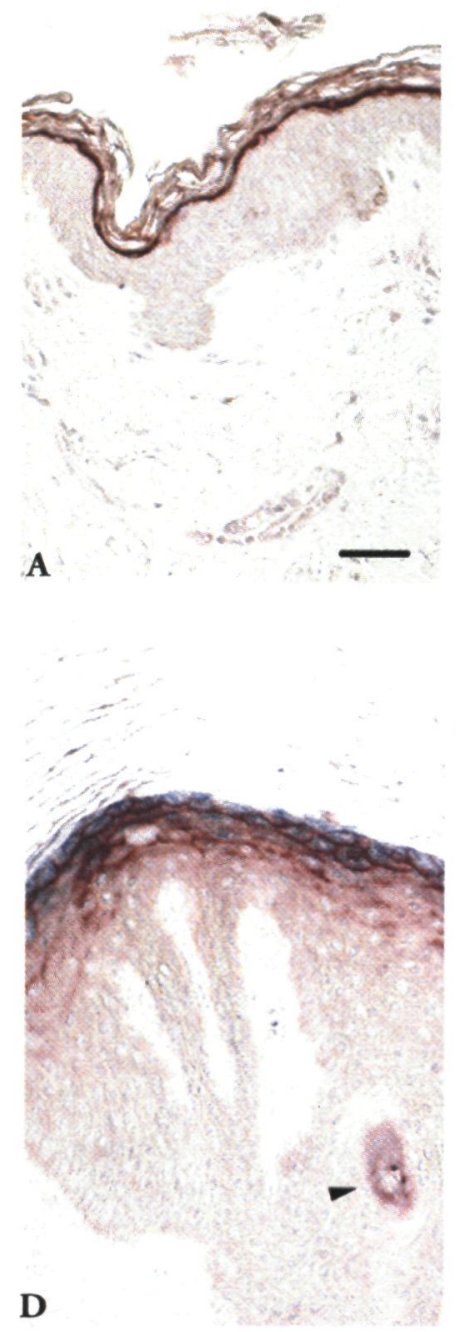

CHAPTER 6 - FIGURE I, PAGE 137
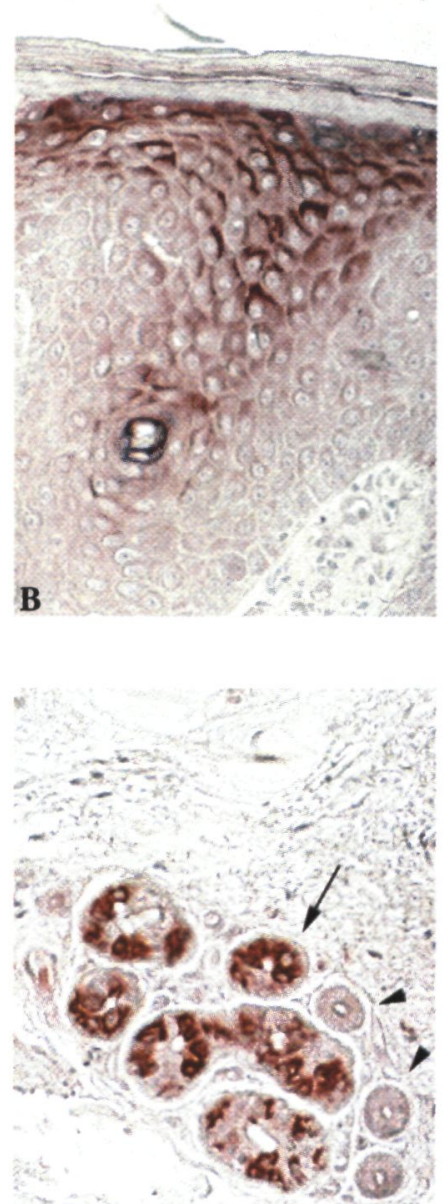

30 as son

$\mathbf{E}+2, \ldots+\ldots$
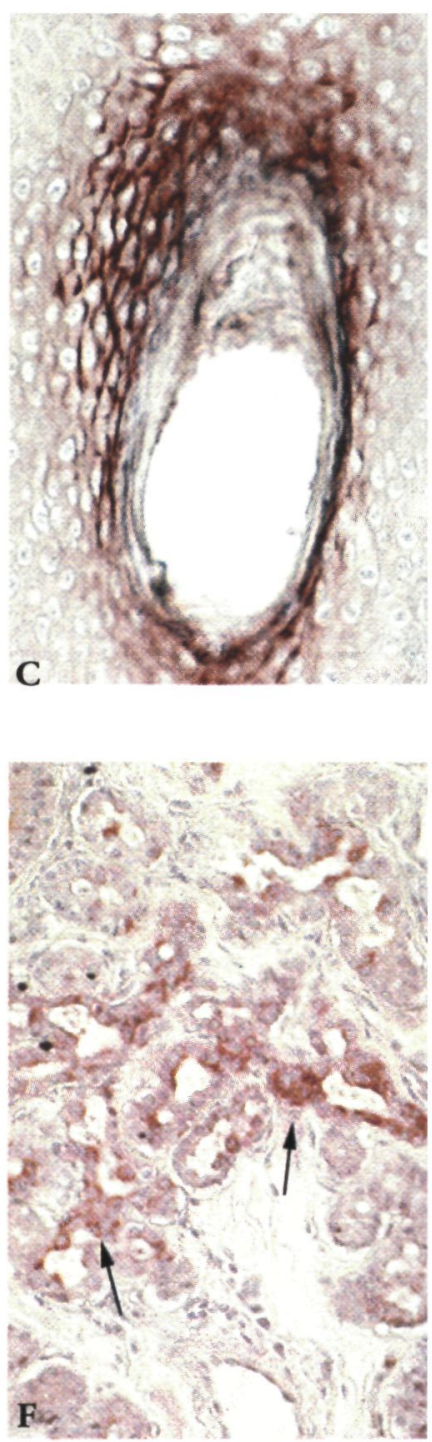

1 Serial Analysis of Gene Expression (SAGE) stelt de onderzoeker niet alleen in staat om absolute genexpressie-niveau's te bepalen, maar ook om nieuwe genen te ontdekken

DIT PROEFSCHRIFT

2 Een op het eerste gezicht onvermoede mogelijkheid die door SAGE wordt geboden, is dat ook differentiele polyadenylering op grote schaal kan worden onderzocht, hetgeen meer inzicht kan verschaffen over verschillen in mRNA processing, mRNA. stabilitert en translatie met betrekking tor diverse (patho)bıologische processen

DIT PROEFSCHRIFI

3 De suggestie van Margulies et al. dat ditags beter op ijs kunnen worden gehouden gedurende de SAGE procedure om een 'scheve' representatie door 'GC content bias' in een SAGE bank te voorkomen, is een open deur

DIT PROEFSCHRIFT

Margulies E.H, Kardı S I , Innıs J W. Identrficaton and prevention of a GC content bias in SAGE libraries Nucleıc Acıds Res 2001,29(12) E60-0

4 Aangezien de apoptotische respons van keratinocyten afhangt van de mate van differentiatie, dient ieder onderzoek naar apoptose in deze cellen, waarbij geen rekening is gehouden met differentiatie, met een korrel zout genomen te worden

5 De genetische code van het humane genoom heeft toegang verschaft tor de kluis van het leven, maar ze hadden er wel even bij mogen zeggen dat het daar een enorm doolhof is

6 Gelijkheid betekent eerbiediging van het anderszijn, en derhalve van natuurlijke ongelijkheid

Johge Semprun in 'Wat efn mooie zondag!'

7 Wie een Fortuyn verdient aan demagogie kan beter ver van de staatskas gehouden worden

8 Aan een dienstregelıng heb je, wanneer je 'op een rijdende trein sprıngt', gezien de recente problemen van de Nederlandse Spoorwegen ook helemaal niets meer

9 One of the culrural advantages of living in Los Angeles is that one can turn right on a red light

10 In a world wichout walls and fences, nobody needs Windows and Gates 



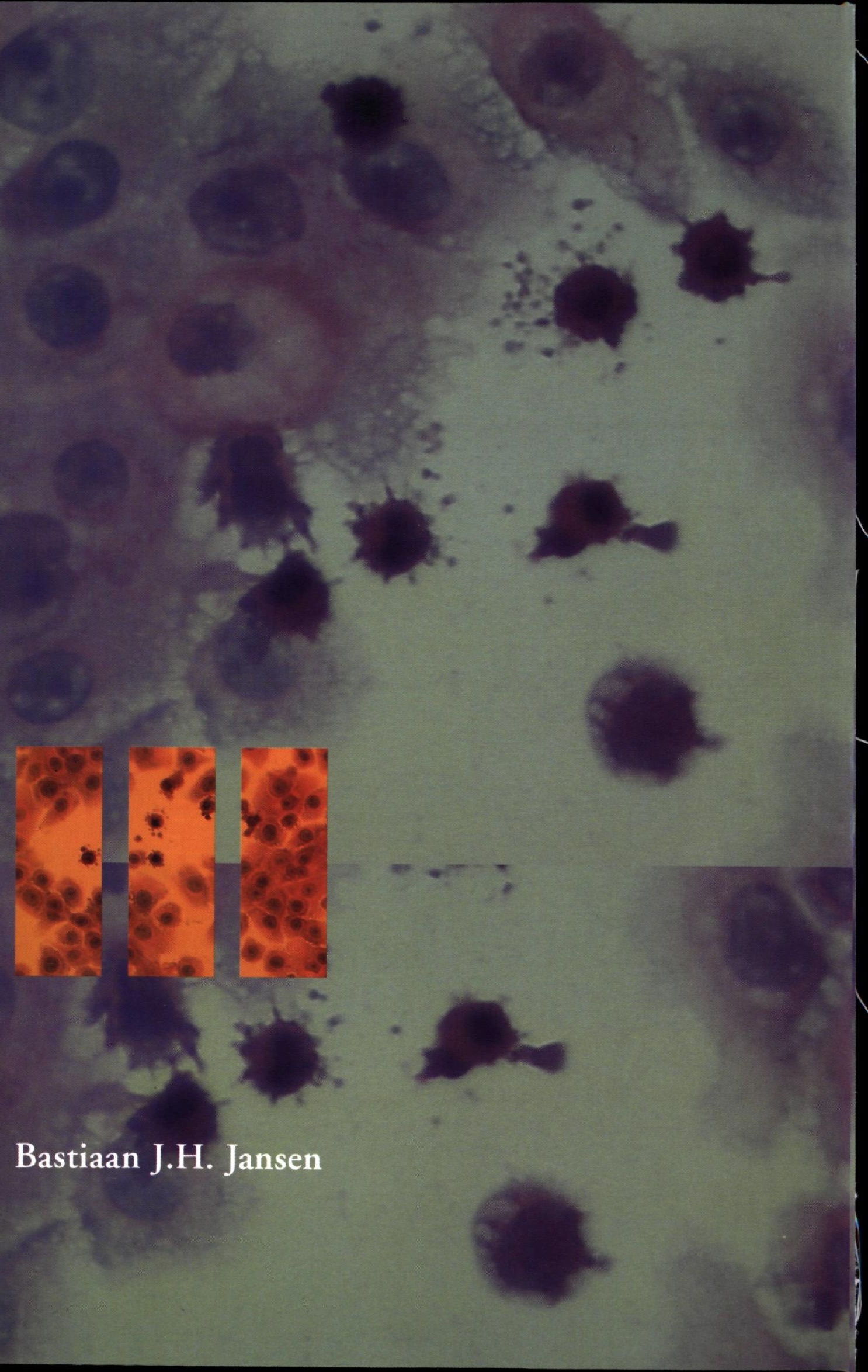

